\title{
"Als je leven zoekt" : gezondheid en genezen in antropologisch perspektief : Joodse traditie als levensorientatie
}

Citation for published version (APA):

op Root, J. M. H. (1984). "Als je leven zoekt" : gezondheid en genezen in antropologisch perspektief : Joodse traditie als levensorientatie. [Doctoral Thesis, Maastricht University]. Rijksuniversiteit Limburg. https://doi.org/10.26481/dis.19841130jo

Document status and date:

Published: 01/01/1984

DOI:

10.26481/dis.19841130jo

Document Version:

Publisher's PDF, also known as Version of record

Please check the document version of this publication:

- A submitted manuscript is the version of the article upon submission and before peer-review. There can be important differences between the submitted version and the official published version of record.

People interested in the research are advised to contact the author for the final version of the publication, or visit the DOI to the publisher's website.

- The final author version and the galley proof are versions of the publication after peer review.

- The final published version features the final layout of the paper including the volume, issue and page numbers.

Link to publication

\footnotetext{
General rights rights.

- You may freely distribute the URL identifying the publication in the public portal. please follow below link for the End User Agreement:

www.umlib.nl/taverne-license

Take down policy

If you believe that this document breaches copyright please contact us at:

repository@maastrichtuniversity.nl

providing details and we will investigate your claim.
}

Copyright and moral rights for the publications made accessible in the public portal are retained by the authors and/or other copyright owners and it is a condition of accessing publications that users recognise and abide by the legal requirements associated with these

- Users may download and print one copy of any publication from the public portal for the purpose of private study or research.

- You may not further distribute the material or use it for any profit-making activity or commercial gain

If the publication is distributed under the terms of Article $25 \mathrm{fa}$ of the Dutch Copyright Act, indicated by the "Taverne" license above, 
ALS JE LEVEN ZOEKT 
"ALS JE LEVEN ZOEKT"

EN GENEZEN IN ANTROPOLOGISCH
PERSPEKTIEF: ORIENTATIE.
PROEFSCHRIFT

ter verkrijging van de graad van doctor in de geneeskunde a an de Rijksuniversiteit Limburg te Maastricht op gezag van de Rector Magnificus Prof.dr.H.C.Hemker, volgens besluit van het College van Dekanen in het openbaar te verdedigen in de aula van de universiteit op vrijdag 30 november 1984 des namidalas om 16.00 uur precies door

JOSEPHUS MARTINUS HENRICUS OP ' $T$ ROOT geboren te Nederweert. 
PROMOTORES :

Prof.dr.J.Sperna Weiland, Rotterdam Prof.dr.C.A.de Geus, Mastricht

\section{REFERENTEN :}

Prof.dr.B.Maoz, Beer Sheva, Israël

Prof.dr.H.Philipsen, Maastricht

Dr.I.B.H.Abram, Amsterdam

Manuskript:

Sekretariaat kapaciteitsgroep huisartsgeneeskunde
B. Köhlen

B. Meerstad 
"Maak mij de weg van het leven bekend" (Psalm 16,11). 
Voor Doortje

Voor Jeroen, voor Guido. 
Gezond zijn houdt voor de mens niet alleen in, dat hij lichamelijk niet ziek is, mat ook dat het hem mogelijk is als mens te leven. In deze zin is ook genezen niet alleen gericht op herstel van gebrek en/of ziekte, maar steeds ook op het (weer) verkrijgen van menselijk leven. Gezondheid en genezen in de hier bedoelde ruime, antropologische, kontekst, vormen het vertrekpunt van deze studie. De mens die gezondheid en genezing, dat wil zeggen die 'leven' zoekt, doet dit met het oog op heel zijn mens zijn.

De inzichten omtrent 'leven', die in onze westerse kultuur verankerd liggen, zijn in een eeuwenlange ontwikkeling opgebouwd. In een tijd als de onze, waarin veel van de waarden van deze kultuur en daarmee van het leven en van het mens zijn op het spel staan, en waarin veel mensen hun oriëntatie zijn kwijtgeraakt, is het zowel voor individuele personen als voor gemeenschappen van het grootste belang voeling te houden met de geestelijke uitgangspunten die aan onze beschaving ten grondslag liggen.

De uitgangspunten die de basis vormen van onze christelijke en humanistische wereld zijn afkomstig van het Grieks-romeinse en van het joodse erfgoed. De bron die, met name in wetenschappelijke kringen, nauwelijks aandacht krijgt, is deze joodse leef-en denkwereld die, op haar beurt, weer op de omgang met de Hebreeuwse bijbel berust. De autenticiteit van deze traditie - en dit beseffen weinigen leeft tot op de dag van vandaag voort naast en in onze christelijk-humanistische wereld. Het is dan ook goed om, 'als je leven zoekt', kennis te nemen van dit joodse weten. Het antropologische perspektief dat met betrekking tot leven, gezondheid en genezen in deze studie geboden wordt, is het perspektief van de jood- 
se traditie.

Het lezen van dit boek vragt van de lezer nogal wat geduld en doorzettingsvermogen. Van hem wordt allereerst gevraagd kennis te nemen van de joodse traditie en open te staan voor het weten dat daarin aanwezig is. Voorts wordt hij erop aangesproken zowel 'de beweging' mee te maken, dat het joodse weten op leven en op mens zijn betrokken is en hiervoor van belang is, alsmede er mee in te stemmen, dat de in zichten van deze traditie van warde zijn als het gaat om een antropologisch perspektief voor gezondheid en genezen.

Het heeft mij, als aanvankelijke leek en buitenstaander, overigens zeven jaren van studie gekost om inzicht te krijgen in de aard en de strekking van de joodse denk- en leefwereld en om de relevantie ervan voor ons leven te leren kennen. Bovendien kostte het een aantal jaren om datgene wat eigenlijk niet op papier te zetten, mar uitsluitend te ontmoeten en te (be)leven is, in woorden uit te drukken. Het resultaat wil ik graag in de vorm van deze 'prolegomena' ter toetsing en ter bespreking aan $U$ voorleggen.

Met betrekking tot de titel merk ik nog het volgende op. Dodo van Uden vertalde enkele jaren geleden uit de Midrasj-verzameling 'Leviticus Rabba" (een verzameling rabbijnse geschriften) een 'midrasj' (uitleg, vertolking) op Psalm 16:11. Ik ben har erkentelijk dat ik voor de titel van dit boek van haar vertaling gebruik kan maken. Ik citeer hier de betreffende passage: "Maak mij de weg van het leven bekend' (Ps 16,11). David zei tot de Heilige-gezegend-zij-Hij: Mak mij bekend wat de poort is die openstaat naar het leven van de komende wereld. Rabbi Joedan zei: David zei tot de Heilige-gezegend-zij-Hij: Heer der werelden. makk mij de weg van het leven bekend. Daarop zei de Heilige-gezegend-zij-Hij tot David: Als je leven zoekt, let dan op de vrees, 
want er is gezegd: De vreze des Heren voegt dagen toe' (Spreuken 10,27). Rabbi Azarja zei De Heilige-gezegena-zij-Hij zei tot David: David, als je leven zoekt, let dan op de beproevingen, want er is gezegd: "En de tuchtingen van de beproevingen zijn een weg des levens" (idem 6,23). En de leraren zeiden: De Heiligegezegend-zij-Hij zei tot David: David, als je leven zoekt, let dan op de Tora, want er is gezegd: 'Een boom des levens is zij voor wie haar kan vastgrijpen' (idem 3,18$)^{\text {m }}$ (van Uden $1981,41-42 ;$ Miarash Rabbah, LeV.R.,XXX, 2; Midrasch Tehil1 im I/II, XVI, 12).

Van degenen die mij geholpen en vooral bemoedigd hebben bij het leren kennen van het joodse weten, moet ik twee mensen met name noemen. Dit is allereerst Dr.o. Warmenhoven, mijn leermeester in de theoretische andragologie. Op nog jonge leeftijd overleed hij in 1983. De tweede naam die ik met dankbaarheld noem is die van Dr.med.Rudolf Diepen uit Frankfurt am Main.

Graag wil ik ook mijn beide promotoren, prof. dr.J.Sperna Weiland en prof.dr.C.A.de Geus, danken. Prof.Sperna Weiland dank ik voor zijn stimulerende en voor zijn zorgvuldige en zorgzame begeleiding. Prof. De Geus ben ik dankbaar voor zijn inzicht in de relevantie van het thema en voor het in mij gestelde vertrouwen. Mijn dank geldt ook de referenten: prof.dr.B. Maoz, prof.dr.H.Philipsen en Dr.I.B.H.Abram. Het entoesiasme warmee prof. Maoz het manuskript gelezen heeft en we samen "gelernt" hebben, heeft me diep getroffen; "Schutzwehr warst au" (Jes.25:4). Prof.Philipsen ben ik zeer erkentelijk voor zijn steun en voor de gedegen wijze warop hij het konsept van het boek doorgewerkt heeft. Het kontakt dat ik met Dr. Abram mocht hebben, bemoedigde mij ten zeerste.

Het typewerk en het manuskript werden op een zorgvuldige wijze verzorga door mevr.M. In de Braekt-Crutzen, mevr.M.Bruijstens. mevr. B . 
Köhlen, mevr.I.Siegelaer-Gerardu en J.Tatipata. Speciaal dank ik mevr.siegelaer voor het vele voorbereidende werk. Mevr.Köhlen dank ik voor de prettige samenwerking en voor de wijze warop zij de eindredaktie verzorgde.

Voor het kritische doorlezen van de konsepttekst dank ik mevr.drs.A.de Graaf en mevr.drs. H.Wasser.

Tenslotte dank ik mijn kollegae van de kapaciteitsgroep huisartsgeneeskunde en met name de kollegae van de subgroep huisartsopleiding voor hun steun en hun geduldig vertrouwen. Het werk draag ik op aan Jeroen en Guido en in het bijzonder aan Doortje: "Du lehrst mich kennen den Pfad des Lebens". 
1. INLEIDING

1.1 Uitgangspunten

1.2 Gezond zijn

1.2 .1 over betekenis en gebruik van de woorden "gezond" en

"gezondheid"

1.2.2 Gezond $\mathrm{zijn}$ en antropologische kontekst

1.3 Mens zijn

1.3.1 "De mensen hebben geen leven"

1.3.2 "De mens zichzelf een vraagstuk"

1.4 Verantwoording

1.4.1 Vraagstelling

1.4.2 Autobiografische verantwoording

1.4.3 Wetenschappelijke verantwoording

1.4.4 De opzet van deze studie

FILOSOF ISCH-JOODSE WETEN

2.3.1 Inleidende opmerkingen

2.3.2 Deel I: "Die Elemente oder die immerwährende vorwelt"

2.3.3 Deel II: "Die Bahn oder die allzeiterneuerte Welt"

2.3.4 Deel III: "Die Gestalt oder die ewige veberwelt" 
2.4 Rosenzweigs verdere leven en werk, met name het leerhuiswerk

2.5 Enkele antekeningen

3. JOODSE TRADITIE 76

3.1 Inleiding 76

3.2 Joodse traditie en Torah 80

3.2 .1 Torah 80

3.2.2 De schriftelijke en de mondelinge Torah 84

3.3 Leven is leren, leren is leven 89

3.3.1 De vertolking van de Torah 89

3.3.2 Leren om te leven en de
betekenis van het leerhuis

3.4 Enkele aantekeningen

4. GEZONDHEID EN GENEZEN IN DE JOODSE TRADITIE: EEN VERKENNING

4.1 Inleiding

4.2 Gezondheid en genezen in Bijbel en Talmoed

4.2.1 "Denn ICH bin dein Arzt"

4.2.2 Gezondheid en genezen in het 'oude Israël'

4.2.3 Gebed on genezing

4.3 Genees- en gezondheidskunde in de Middeleeuwen: Mozes Maimonides

4.4 Gezondheid en genezen in het huidige jodendom 
4.4.2 Opvattingen uit de filosofisch-joodse Iiteratuur

4.5 Enkele aantekeningen

161

5. ENKELE HUISARTSGENEESKUNDIGE KONSEPTEN NADER GEINTERPRETEERD VANUIT HET JOODSE WETEN

5.1 Inleiding

5.1.1 Een "nieuw leren": vanuit onze situatie naar de joodse traditie

5.1.2 Huisartsgeneeskunde en enkele van haar basiskonsepten

5.2 Integrale geneeskunde en de betekenis van de woorden "integer" en "integriteit" in het joodse weten

5.2.1 Integrale geneeskunde

5.2 .2 Joodse stemmen over integriteit

5.3 Levensloopgeneeskunde en levensen tijdsbeleving in de joodse traditie

5.3.1 Levensloopgeneeskunde

5.3 .2 Levens- en tijdsbeleving

in de joodse traditie

53.3 Ordening van het leven

5.4 Enkele aantekeningen

6. "GELIEFD IS DE MENS"

6.2 Het beeld van de mens in de joodse traditie

6.2.1 "Geschapen naar Gods beeld, naar Zijn gelijkenis" 
6.2 .3 verantwoordelijk zijn

6.3 Joodse medische "halacha"

6.4 "Als je leven zoekt"

256

6.4.1 Genezen, helen, verlossen

6.4.2 "Mein Ich entsteht im Du"

6.5 Enkele aantekeningen

Samenvatting

Summaxy 
HOOFDSTUK 1: INLEIDING.

1.1

Uitgangspunten.

Het woord 'gezond' heeft in onze tijd en in onze samenleving een nogal ruime betekenis. Het heeft niet alleen betrekking op de lichamelijke gezondheid van de mens in de zin van afwezigheid van ziekte en gebrek, maar het omvat ook facetten die liggen op existentieel, geestelijk, psychisch, sociaal, ekologisch en kultureel gebied. Een duidelijk onderscheid tussen deze facetten is niet altijd goed a an te brengen. Wat in elk geval duidelijk is, is dat het woord gezond betrekking heeft op "heel de mens" (Fortmann 1972), op heel het leven van de mens en ook op het menselijk samenleven en de aard hiervan.

ziekte en gezondheid zijn ook subjektieve zaken, niet altijd afhankelijk van de klinische vaststelbaarheid ervan. Dit makt dat het woord gezond ook een dubbele betekenis heeft en in dubbele zin gebruikt kan worden: het kan betrekking hebben op het strikt somatische óf op heel de menselijke persoon. Gezondheid, enerzijds een aspekt van het leven, wordt anderzijds met het mens zijn zelf verbonden. Het goed gezond zijn is dan tegelijk levensperspektief geworden. Het funktioneren als mens is in belangrijke mate verbonden met gezondheid (vgl.Philipsen 1976, 203; Kuiper 1978,1019).

Het woord gezond vertegenwoordigt een hoge warae in ons leven en in onze samenleving (Kuiper 1978,1019). Gezondheid, zo vond Cassee, is de hoogste waarde (Cassee 1973,12-16). Meer recent onderzoek heeft uitgewezen dat deze uitspraak echter gerelativeerd moet worden naarmate men meer vertrouwd raakt met het onderwerp. Gezin, vrede en vrijheid worden dan als even belangrijk of als nog belangrijker 
ervaren (Adriaanse e.a. 1981, 39-44).

Gezondheid is nauw verbonden met genezen en met geneeskunde. De geneeskunde heeft een hoge vlucht genomen en zij heeft veel bereikt, met name op het medisch-somatische vlak. De geneeskunde heeft echter ook, merken Van Es en De Melker op. steeds meer problemen toegeschreven gekregen, die niet op medische wijze kunnen en ook niet zo moeten worden opgelost (Van Es en De Melker 1978,962).

In zijn positie en funktie als eerstelijns arts (zie Van Es 1980,13-19) ligt hier niet alleen een probleem voor de huisarts (vgl. Bergsma 1981), maar ook een taak en een uitdaging (zie Van Es 1980,24-26). Huisartsgeneeskunde valt te karakteriseren als "longitudinale zorg langs de levensijn met latitudinale awarsdoorsneden door de levensgeschiedenis" (De Geus 1973,256 ).

De, wat ik zou willen noemen, antropologischgezondheidkundige oriëntatie van de huisarts wordt in de literatuur vrij algemeen onderschreven. De inhoud van de huisartsgeneeskunde wordt vooral bepald door "de levensloopgeneeskunde, de integrale geneeskunde en de gezinsgeneeskunde. Deze bieden de mogelijkheid de patiënt te zien als een mens met een geschiedenis, als een totaliteit en in samenhang met zijn ongeving. Het uiteindelijk doel van de huisartsgeneeskunde is de heelheid hiervan te bevorderen" (Van Es 1980,13).

Er valt veel voor te zeggen de huisartsgeneeskunde eerder in een breed antropologisch-gezondheidkundig dan in een strikt geneeskundig perspektief te platisen. De mens, die met klachten - van welke aard dan ook - bij de huisarts komt, is in zijn "gezond bestaan" (Kuiper 1975) bedreigd. Zijn "heelheid', zijn mens zijn is in het geding. Dit vraagt van de huisarts een gezondheidkundige gerichtheid in ruime $z i n$ en een openheid die de vraag wat het is om mens te zijn, in elke konkrete situatie, opneemt (zie Draper and Smits 1975,905). Van- 
zelfsprekend mag dit niet tekort doen an het medisch-somatisch aspekt, voorzover dit relevant is (vgl. Moll 1978,39-47).

Gezond zijn en gezondheid zijn verbonden met wat mensen in hun leven vór hebben (Kuiper 1978 1022). Dit kan ook het bezit van een goede gezondheid zijn! Kuiper merkt bovendien op, dat alleen het subjekt zelf kan uitmaken welke waarde gezondheid voor hem heeft. "Alleen hij kan de plaats van gezondheid in de kontekst van zijn eigen bestaan bepalen". Kuiper zegt voorts, dat het hier om een persoonlijk recht gaat (id.,1022). Tegelijk betreft het een waarde met een zekere betrekkelijkheid en gaat het om een met de kultuur samenhangende waarde (vgl.id.,1023-1024). De opvattingen over wat gezondheid is, zijn verbonden met de kultuur en met de situatie van de kultuur en de samenleving.

Een belangrijk probleem van onze tijd is het volgende: de geneeskundige en de gezondheidkundige oriëntatie hebben rechtstreeks betrekking op de mens en op zijn leven, maar tegelijk is er grote onzekerheid over wat het is om mens te zijn. Wij leven in een tijd van snelle verandering en "algemeen is er de overtuiging, dat wij leven op een breuklijn in de geschiedenis" (Sperna Weiland $1966,1972{ }^{8}, 27$ ). Wij bevinden ons, zo zegt Van Peursen "in een overgangstijd" (Van Peursen 1972).

In antropologisch-gezonaheidkundig opzicht gaat het hier on een belangrijk punt. Talloze auteurs wijzen op het voorkomen van gevoelens en gedragingen van vervreeming, van eenzaamheid, van alleen zijn, van onzekerheid, angst en desoriéntatie. "De veranderingen die zich in onze kultuur en dus in de mens voltrekken zijn voor tallozen vandaag een bron van zorg, spanningen, onzekerheid en desintegratie" (Fortmann $\left.1959,1971^{8}, 16\right)$. Waar de gezondheidszorg in onze tijd mee gekonfronteerd wordt is de vraag wat een waraig, dit wil zeggen menselijk, leven is. De vragen naar 'leven' wor- 
den vaak in gezondheidstermen verhald en vertaald (vgl.Breung 1980,12). Het gaat hierbij om vragen naar onze toekomst, om vragen naar wat het leven waard is en om vragen naar wat het (nog) wil zeggen om mens te zijn.

Zowel voor individuen als voor gemeenschappen (ook voor universitaire) en beschavingen is het in tijden van krisis en verandering van het grootste belang voeling te houden en verbonden te blijven met de de oorspronkelijke levenswaarden van de eigen kultuur en geschiedenis, met andere woorden met "het weten' dat aan onze kultuur ten grondslag ligt. Voor onze christelijke en humanistische wereld liggen de bronnen en uitgangspunten onder andere in de hellenistische c.q. de Grieks-romeinse én in de Hebreeuwse c.q. joodse beschaving (Vaq der Aalst 1974 ; Boman $1952,1977^{\circ}$; Störíg 1, 1974 ).

De joodse kultuur op hal beurt, berust op het ongaan - in leven en leren - met de Hebreeuwse bijbel (Tenach) en specifiek met de Torah. Dit heeft geresulteerd in een onafzienbare hoeveelheid literatuur, warin het joodse weten verwoord is. Tot op de dag van vandaag gat dit door. Overigens is in onze voornamelijk op het hellenisme gebouwde kultuur het joodse denken betrekkelijk onbekend gebleven. Zowel het christendom (Van der Aalst 1974) als ogs wetenschappelijk denken (stoorig 1,1959,1974 ${ }^{13}$ ) is sterk hellenistisch gekleurd. Weinig mensen beseffen, dat de joodse woorden tot op de huidige dag levende werkelijkheid zijn en dat zij telkens weer worden verwoord.

De joodse kultuur of traditie is niet alleen relevant als een van de bronnen van onze kultuur en ook niet alleen als een levende werkelijkheid, die erkenning en integratie behoeft, maar ook, omdat mens zijn en menselijk leven in de joodse traditie als van zeer hoge warde beschouwd worden (Bleich 1981,22; Franck 1983, 211).

Leven en overleven en leren en overleveren spelen een belangrijke rol. Het jodendom is 
"Zeuge für die ganze Menschheit von Leben gegen den Tod, von geistiger Gesundheit gegen Wahnsinn" (Ilsar 1980,40). "As the world cannot endure without winds, so too the world cannot exist without Israel", zegt de Talmoed (Bab.Talm. Ta"anith 3b). In zijn boek "Joodse traditie als permanent leren', spreekt Abram van "learning to be or not to be". Abram doelt hiermee op het samenhangend geheel van "leven, leren en overleven". Bovendien, zo zegt hij. wordt in het jodendom "niet alleen maar geleerd om te leven en te overleven, maar ook om te herinneren en over te leveren" (Abram 1980, 18).

De joodse traditie heeft van oudsher in de inrichting en de regulering van de samenleving veel aandacht besteed aan zaken, die het gezonde bestaan bevorderen (Muntner 1971). Vanuit het jodendom is ook een belangrijke bijdrage geleverd aan de westerse genees- en gezondheidkunde (Enc.Jud.,Vol.11,1178-1211). Gezond zijn is in de joodse traditie niet beperkt tot het fysieke aspekt van het mens zijn, maar "health is profoundly related to one"s way of thinking, to one's sense of values" (Heschel 1959,1975 2,32 ). Ziekte wordt als een krisis van de gehele persoon en diens leven opgevat (id.,32).

De mens die gezond is, is het beste in stat te leven naar de Torah. En dáárom gaat het in de joodse traditie (zie hoofstuk 3). Op zijn beurt is iemand die leeft nar de Torah en de Torah bestudeert weer een "heel' en in dat opzicht gezond mens te noemen.

In dit hoofdstuk ga ik nog verder in op de aspekten 'gezond zijn' en 'mens zijn' die in deze inleidende paragraaf terloops an de orde zijn geweest. In 1.2 . wil ik laten zien, dat gezond zijn en gezondheid niet louter op de lichamelijkheid van de mens betrekking hebben, maar dat zij met mens zijn en leven van doen hebben. In 1.3 . ga ik in op de hulsartsgeneeskunde en op de vragen naar leven, warmee deze 
gekonfronteerd wordt, $c \cdot q$. op de vragen om welke gezondheld en welk leven het hier gaat. In 1.4. besteed ik aandacht aan de vraag naar de mens en aan de vraag wat het wil zeggen om mens te zijn. In 1.5. geef ik een nadere verantwoording van deze studie, met name ook een wetenschappelijke verantwoording en geef ik het verdere perspektief ervan aan. De overstap naar de joodse gedachtenwereld gebeurt dan in hoofdstuk 2 .

Eén opmerking moet mij nog van het hart. Ter voorkoming van mogelijke misverstanden moet ik aantekenen dat de joodse traditie niet louter en niet zonder meer als een godsdienst op te vatten is en dat het joodse weten ook niet strikt theologisch van aard is. Het jodendom is niet alleen een religieuze traditie, maar ook en vooral een leer-en levenstraditie van een volk, dat probeert te leven met en te handelen naar de wetenschap die in de Torah en in de mondelinge traditie (zie hoofdstuk 3) met betrekking tot het leven van de mens verwoord wordt (vig.Heschel $\left.1955,1976^{3}, 412\right)$. In de joodse traditie gat het altijd om de mens. "Judiasm rests upon an anthropocentric view of the world" (Cohen 1971, 286).

1.2. Gezond zijn.

$1 \cdot 2 \cdot 1$ Over de betekenis en het gebruik van de woorden gezond en gezondheid.

Bij de etymologisch onduidelfjke woorden "gezond" (De Vries 1958,197912,79) en "gezondheld" denken we, zegt 'De Grote oosthoek' in de eerste plaats aan 11 chamelijke gezondheid. "Gezond" heeft dan verschillende betekenissen, namelijk: "zonder lichamelijk letsel, ongedeerd; door geen lichaamsgebrek belemmerd; 
kloek, stevig; welvarend; niet gekweld door ziekte, niet ziek; van een ziekte hersteld".

'Gezond" wil echter ook zeggen: "gezond van lichaam en geest". Het woord gezond kan dus ook een meer "innerlijke betekenis" hebben. zoals tot uiting komt in uitdrukkingen als: "gezond verstand, een gezond oordeel, gezonde denkbeelden, gezonde taal, een gezonde levensbeschouwing, gezonde gevoelens".

"Gezond" kan betrekking hebben zowel op "onstoffelijke", als op "stoffelijke" zaken. Enkele voorbeelden hiervan zijn: "de zaak is gezond, dat is geen gezonde toestand, een gezonde vrucht, gezond hout" (in dit latste geval betekent het: "gaaf, ongeschonden, deugdelijk"). Tenslotte heeft "gezond' de overdrachtelijke betekenis van: "heilzaam, bevorderend voor het welzijn" (bijvcorbeeld: "water is gezond, die straf is wel gezqnd voor hem"). (De Grote Oos thoek, d1.8,1978,315-316).

Gezond en niet gezond zijn hebben niet alleen betrekking op de lichamelijke toestand van iemand, maar ook op andere facetten van het mens zijn. Gezond zijn heeft niet alleen te maken met hetgeen klinisch c.q. medisch-diagnostisch vaststelbaar is als niet ziek, mar ook met eigenschappen, belevingen, ervaringen, inzichten en opvattingen van de mens, die aan zijn persoon en aan de kultuur waarin hij leeft, gebonden zijn. De huisarts De Vries noteerde in zijn onderzoek de volgende uitspraken van zijn patienten:

" - ik voel me wel ziek, mar van harte ben ik gezond :

- dokter, ik ben een gezonde patiënt:

- hoewel ik een ziekte heb, voel ik mijgezond:

- hoewel ik vaak met mijn gezondheid sukkel, ben ik zelden ziek;

- mijn gezondheid wordt door ziekten ondermijnd;

- hij moet wel ongezond zijn, want hij is zo vaak ziek" (De Vries 1973,30).

Hieruit blijkt dat het mogelijk is om ziek te 
zijn en toch zichzelf in zijn mens zijn als gezond te ervaren. Het is juist deze ervaring van gezond mens zijn warop ik in deze studie het aksent wil leggen. In mijn gedachtengang kan iemand 'menselijk' gezond zijn, dat wil zeggen 'heel' mens zijn, terwijl zijn fysieke gezondheidstoestand noch volmaakt is noch met betrekking tot de verschillende facetten van gezondheid in een toestand van evenwicht behoeft te zijn.

Ik vat het word gezond positief op en niet negatief in de zin van "afwezigheid van ziekte of gebrek". Gezond zijn is meer en anders dan niet-ziek-zijn. Het woord heeft betrekking op mens zijn en op leven. Het is met name in deze, antropologische, betekenis dat ik het gebruik.

ook het woord 'gezondheid' wordt in deze ruime betekenis gebruikt. 'Gezondheid' heeft allang niet meer bij uitstek betrekking op het lichamelijk welzijn. De volgende (negatieve) omschrijuing van 'afwezigheid van gebrek, zwakte en ziekte' is niet de enige. 'Gezondheid" is positief te omschrijven als "de toestand van optimaal welzijn in lichamelijk, geestelijk en maatschappelijk opzicht" (Oosthoek 1916-1925. $1976-1981,316)$.

Deze omschrijving brengt ons bij de standaarddefinitie van de World Health organization (W.H.O.). De in Genève gevestigde Wereld Gezondheidsorganisatie kwam tot de volgende definitie: "Health is the presence of complete physical, mental and social well-being (of the individual) and not merely the absence of disease gr infirmity" (o.a. bij Antonovsky $\left.1979,1980^{2}, 52\right)$. Ook de W.H.O. vat de betekenis van het begrip gezondheid ruim op; dit wil zeggen dat ook zij streeft nar een definitie van gezondheid, die op het menselijk leven in al zijn facetten betrekking heeft.

Gezondheid is geen geisoleerd begrip. Het is, zoals al gezegd, verbonden met het mens zijn en met het eigen mens- en levensontwerp, met 
de reden van bestaan, met de betekenis die men aan het leven geeft. Bovendien kan alleen de individuele persoon uitmaken en ervaren wat gezonaheid voor $\mathrm{zijn}$ leven betekent (v1g.Kuiper 1978,1022;id.1980,144-146; Frank1 1980,37). Elke mens is in vrijheid verantwoordelijk zowel voor zijn eigen gezondheid (gezondheidkundig moment) als voor zijn eigen mens- en levensontwerp (antropologisch moment).

$1.2 \cdot 2$. Gezond zijn en antropologische kontekst.

Gezondheid heeft te maken met het menselijk leven en de levensloop van de mens. Er is sprake van één gezondheid en strikt genomen is er ook maar één gezondheidszorg, zegt sporken, namelijk die van de (gehele) mens (Sporken 1977,45). Alhoewel praktische en operationeel-wetenschappelijke motieven in de omschrijving van wat gezondheid is, een rol kunnen spelen, is toch vooral het antropologisch motief essentiëel, stelt Kuiper (Kuiper 1975, 11-12). Met Kuiper ben ik van mening, dat dit antropologisch motief of nivo de primaire kontekst is waarin het gezond mens zijn geplaatst behoort te worden.

ook Van Es, die zich heeft laten leiden door de opvattingen van Kuiper en voorts door die van Fortman en Levinas, begeeft zich bij het omschrijven van de term "gezondheid' op antropologisch nivo. Gezondheid heeft volgens hem op de eerste plaats te maken met "in leven (willen) blijven". Gezondheid heeft daarnaast te maken met "de zingeving aan het bestaan" en deze ligt in "het verantwoord leven in deze wereld". Gezondheid vertoont voorts "een nauwe relatie met vrijheid". ziekte kan iemands vrijheid blokkeren. Ook kan de geestelijke vrijheid belemmerd worden door "gevoelens, wensen, stremmingen en ariften die uit de diepte van ons opstijgen en die zich aan de 
wil en aan het verstand kunnen onttrekken". Gezondheid brengt met zich mee, zegt Van Es, "dat men in staat is bewust te leven, het eigen handelen te overzien, de eigen belemmeringen te herkennen en darmee om te gaan. Gezondheid betekent dus ook, dat men herkent waaraan men gebonden is". Als vierde en laatste aspekt noemt Van Es het aspekt van "de tijd" "De mens moet mens kunnen worden. Dit houdt ook in, "dat men zich als mens in zijn historiciteit ontwikkelt (...). Dit vergt een liefdevolle omgang met de wereld, met zichzelf en met de ander, en is de voorwarde om de grenzen naar de ander te overschrijden en om ook van zichzelf af te zien" (Van Es 1980,7273).

Op existentieel-antropologisch nivo is er een fundamentele samenhang tussen het somatisch, psychisch en sociaal aspekt van gezondheid. Gezondheid heeft ook betrekking op het relatiepatroon van mensen en op de wijze waarop zij zich in de buitenwereld gedragen. Bovendien heeft gezondheid betrekking op de kwaliteit van de relaties (Lee and Franks 1980,48). Gezond zijn wil in een antropologische kontekst bovendien zeggen dat de mens samenhang ervaart in de levensbeweging van verleden-heden-toekomst en dat hij beseft en aanvaardt deel uit te maken van een werkelijkheid met veranderingen die hem aan den lijve gebeuren en hem persoonlijk aangaan. Gezond mens zijn wil tenslotte zeggen leven in een besef van samenhang met de mede-mens, met 2 de wereld en met God (vg1. Antonovsky $1979,1980^{2}, 8$; Van Es $1980,74)$.

Een dergelijk konkreet en persoonlijk te beleven wel-bevinden is kenmerkend voor de in existentieel-antropologisch opzicht gezonde mens. Het houdt dan in dat men er weet van heeft 'heel' mens te zijn en dat men door en door ervaart als mens te leven.

Van Es vult bij het woord 'heel' aan, dat ook de woorden 'heil' en 'heilig' hiervan afgeleid 
zijn (Van Es 1980,73). Bovendien staat het woord 'helen' ermee in verband. In het Engels zijn de woorden 'well', 'whole' en 'health' taalkundig aan elkaar verwant, evenals de woorden 'hail' en 'holy'. Ook 'to heal' en de hiervan afgeleide vormen $\mathrm{zijn}$ ermee verwant. Oorspronkelijk betekent "heel-zijn" onbeschadigd gebleven zijn, zegt de filosoof Bollnow onbeschadigd door de strijd van het leven. Maar er is heling mogelijk van de opgelopen verwondingen. Ondanks de opgelopen en op te lopen kwetsuren kan het menselijk leven toch heel, dat wil zeggen gaaf, zijn. Het één-ge heel-zijn en het gaaf zijn horen bij elkaar. Het heel zijn wordt door Bollnow zowel op de mens als op de wereld van toepassing geacht. ook dingen kunnen heel zijn (Bollnow 1958, $\left.1967^{2}, 109-116\right)$.

In de joodse traditie als traditie van aktief permanent leren (zie hoofdstuk 3) wordt niet zozeer voor een beroep geleerd, ook niet voor het verkrijgen van macht of gezag. Het belangrijkste einddoel is een "whole Jew", met ander woorden "een gaaf mens" te worden (Abram 1980, 219). Het gaat erom 'heel' mens te zijn, met andere woorden om gezond (= gaaf) mens te zijn. De Hebreeuwse woorden voor (ge)heel zijn 'tamiem' en 'sjaleem'. Zij betekenen ook: gezond, wel, volledig, gaaf. Sjaleem is voorts verwant met "sjalom', dat vrede betekent. Mede gelet op de verwantschap tussen whole, well en health - en ik volg nu Abram - is volgens de joodse traditie een "whole Jew" dus een "gaaf mens", "knowing the Torah, fearing God, observing the commandments, and inculcating them with such a love of God that when called upon they would readily give up their lives for the sanctification of God's name" Abram citeert hier de historicus Simha Asaf (1889-1953). (Abram 1980,219). De relatie tussen mens zijn en jood zijn werd ook door Franz Rosenzweig (zie hoofdstuk 2) gelegd. Voor hem betekende zijn persoonlijk zoeken naar zijn 
mens zijn, dat zijn jood zijn weer het centrale gegeven van zijn leven werd (vgl.Rosenzweig $1937,81-82$ en 96-97).

De katholieke, aan de Hebreeuwse Universiteit in Jerusalem docerende en sterk door de joodse traditie beinvloede, wijsgeer Dubois legt er de nadruk op, dat gezond mens zijn de erkenning inhoudt van een spirituele en transcendente dimensie in het leven. Deze dimensie blijft voorop staan, ook al lijkt de macht die de mens heeft door de mogelijkheden van de techniek wel eens andere perspektieven te geven. De uitoefening van deze macht is begrensd en dit vraagt om een houding van "deemoed" (Dubois 1980,44).

Datgene wat technisch mogelijk is, hoeft nog niet te beantwoorden aan hetgeen menselijkerwijze juist en verantwoord is. Wat technisch. alhoewel tot stand gebracht door de mens, suksesvol is, hoeft nog niet met betrekking tot de menselijkheid van het leven suksesvol te zijn (zie Fromm 1964,1982,49-54). Onze eeuw heeft dit op grote schaal ervaren. Abram merkt op, dat technisch gezien "Auschwitz", dat wil zeggen de planmatige vervolging en vernietiging van joden, zigeuners, politieke opponenten en andere, het nazi-regiem (1933-1945) onwelgevalilge elementen", en "Hiroshima", dat wil zeggen "het bombarderen van Japanse steden met atoombommen", grote suksessen waren. "Moreel gezien waren Auschwitz en Hiroshima dieptepunten, catastrofen van onmenselijkheid" (Abram 1980,220).

ook in de gezondheidszorg en de geneeskunde heeft de techniek niet het laatste woord. En ook hier geldt, dat wat medisch-technisch mogelijk en suksesvol is nog niet antropologisch-gezondheldkundig verantwoord hoeft te zijn. Ult praktische of wetenschappelijke overwegingen kan het noodzakelijk en juist zijn bepaalde facetten uit de menselijke kontekst te isoleren (vgl.Kuiper 1978,1020-1022). Mar dit isoleren wil niet zeggen, dat de 
techniek richtingbepalend en overheersend mag worden. Het gaat hierbij niet alleen om het stellen van regels, maar ook on een houding. die weet heeft van een antropologisch-transcendente dimensie van het mens zijn (vgl.Dubois 1980,45$)$.

Wanneer de woorden gezondheid en genezen in een meer beperkte betekenis gebruikt worden ook in de joodse traditie - hebben zij toch betrekking op "heel de mens'. Elke medische ingreep of elk voorschrift is niet alleen een ingreep in het lichaam van de mens, maar ook in het leven en de levensloop van de mens. Met de anduiding dat de woorden gezond en gezondheid met mens zijn en menselijk leven verbonden zijn - en daarmee vanuit een antropologische kontekst of in een antropologisch perspektief gezien moeten worden - verschuift het omschrijvingsprobleem van de termen gezond en gezondheid naar de vraag naar de mens en zijn situatie.

1.3

Mens zijn.

$1 \cdot 3 \cdot 1$

"De mensen hebben geen leven".

De vooruitgang van met name de geneeskunde, dankzij de vooruitgang van de natuurwetenschap, leidde tot een geweldige uitbreiding van de geinstitutionaliseerde gezondheidszorg en bovendien tot hooggespannen verwachtingen. De hooggespannen verwachtingen zijn in vele opzichten uitgekomen, maar bepaald niet in alle opzichten, zegt Van Melsen. Gezondheid is meer dan het normal funktioneren van het $1 i-$ chaam (vgl.Van Melsen 1982,264). De vraag is relevant wat "het goede in de geneeskunde" inhoudt (Van Hartingsveld 1981,49). De vraag naar wat goed is, is echter geen vraag die tot het louter medisch-somatische vlak beperkt 
blijft, maar zij heeft betrekking op wat goed is voor een menselijk en een aldus "gezond" leven.

Gezond zijn en gezondheid hebben betrekking op het leven. De mens, die gezondheid en genezing van (veronderstelde) ziekte zoekt, zoekt leven. In de geneeskundige praktijk wordt, naast de psychiater en de sociaal-geneeskundige, vooral de hulsarts gekonfronteerd met allerlei levensproblemen die over het algemeen in termen van gezondheidsklachten en -problemen gepresenteerd worden.

Dit betekent overigens niet, dat de huisarts zich ook daadwerkelijk op grote schaal met niet-medische problemen inlaat. "De professionele grondhouding van artsen", zegt Van Es, "brengt met zich mee dat iedereen die zich als patient meldt als ziek wordt beschouwd, tot het tegendeel bewezen is" (Van Es 1976,1360). op basis van de door hem onderscheiden taakkategorieën toonde Boots in zijn onderzoek aan, dat de huisarts het grootste gedeelte van zijn tijd, namelijk 37,28, aan curatieve zorg - diagnostiek en therapie - besteedt. In de praktijk bleek de huisarts slechts 11,58 van de tijd te gebruiken voor begeleiding, preventie en verwijzing buiten de gezondheidszorg, zoals het maatschappelijk werk (Boots 1983 . $65-69)$.

Uit het onderzoek van Boots komt ook naar voren dat verkleining van de praktijkomvang, stimuleren van samenwerkingsvormen en uitbreiding van ondersteunende voorzieningen als mogelijkheden om de eerste lijn te versterken nog geen verschuivingen in het funktioneren van de huisarts betekenen in de richting van meer begeleiding en preventie en vermindering van de doorstroming naar het tweede echelon. "Het bevorderen van een bewuste, andere opsteling tegenover de inhoud en uitvoering van de taken bij de huisarts, is weliswaar een minder direct aangrijpingspunt, mar lijkt aarentegen meer succesvol" is de konklusie 
van Boots (id.,118). Hieraan zou ik willen toevoegen dat de huisartsgeneeskundige praktijk dringend behoefte heeft aan het leren gebruiken van een methodisch-systematische wijze van konsultvoering, warin de onderlinge verwevenheid van somatische, psychische en sociale problematiek nader getraceerd kan worden en waarin gezondheidsproblemen naar hun betekenis als levensproblemen benaderd kunnen worden (zie Schouten 1982).

Problemen van mensen zijn geen losse, op zichzelf staande zaken, maar zij hangen samen met de (veranderende) leefsituatie en kultuur (vgl. Buber $\left.1968,1978^{2}, 272-273\right)$. Ook veel somatische problemen zijn kultuurproblemen en/of hebben facetten, die met de kultuur samenhangen. Gezondheidsproblemen zijn tevens kultuurproblemen (vgl.Fortmann 1971,16; Kuiper 1978,10231024; Philipsen 1976,205). Als deze problemen niet in een samenhang benaderd worden, blijft oplossing en een gevoel van bevrijaing uit. Het leidt tot cirkelhulp. zoals veel huisartsen weten: "patiënten die rondzwerven van de ene klacht naar de andere, onbevredigdheid die in telkens andere vormen terugkeert, zorg die zich in het leven lijkt te hebben vastgezet als een niet te dichten gat in het bestaan" (Breung 1980;vgl.Baggen $1976,1033)$. Weijel heeft deze onbevredigdheid. dit niet te dichten gat in het bestaan, benoemd als: "de mensen hebben geen leven". zijn boek met deze titel handelt over de mensen en hoe pover zij in onze kultuur leven. Ondanks de welvaart voelen veel mensen zich niet wel. zij lijden aan "welzijnsnood" (Weijel 1970). De mens is voor zichzelf "een vraag zonder antwoord geworden" (Marcel 1956,1969 ,29). Z6́ ernstig vat Marcel de situatie van onze tijd op.

De uit Wenen afkomstige Viktor Frankl heeft zowel in Europa als in de Verenigde staten op basis van zijn ervaringen als psychiater nader onderzoek gedaan naar het karakter van de nood 
van de huidige mens. Kenmerkend is, zo zegt hij. het bestasn van "een gevoel van leegte" van "een existentieel vaculum".

Frankl merkt op "dat wij tegenwoordig niet meer - zoals ten tijde van Freud - gekonfronteerd worden met en seksuele frustratie. "En de typische patient van vandaag" "zo zegt hij verder, "lijdt ook niet meer - zoals ten tijae van Adler - aan een minderwaardigheidsgevoel, mar aan een grondeloos gevoel van zinloosheid, gepard aan een gevoel van leegte; vandar dat ik spreek van een existentieel vaculim" (Frank1 1980,9).

Frank1 noemt dit existentiële vacuüm "een wijd verspreid verschijnsel in de twintigste eeuw" (Frankl 1978,132-133). Het lijden aan een leven dat als zinloos ervaren wordt, heeft de volgende kenmerken: "Steeds meer patienten klagen over een gevoel van leegte en van zinloosheid, dat m.i. door twee feiten wordt veroorzaakt. In tegenstelling tot het dier is het bij de mens niet zo, dat zijn instincten hem zeggen wat hij moet doen. En in tegensteliing tot de mens van vroeger wordt hem ook niet meer door de traditie verteld wat hij behoort te doen. Vaak weet hij zelfs niet wat hij in de grond zelf wenst. In dat laatste geval zal hil ofwel dingen willen die ook anderen willen (conformisme), ofwel dingen doen die anderen hem willen laten doen (totalitarisme)" (Frankl. $1980,8$ en 66$)$.

Kern van de door Frank1 ontwikkelae wijze van helpen is "dat ex een betekenis is en dat het leven in alle omstandigheden zinvol blijft" (1d.,8). Frank1 brengt hierbij zijn eigen ervaringen in herinnering. Hij is overlevende van Auschwitz. Wat hem daar in leven hield en zijn bestaan betekenis gaf, was dat "het leven op hem wachtte" (Frankl 1978,115). Het gaat hier voor ledere Individuele mens om iets unieks en eenmaligs, iets dat lemands zeer persoonlijke leven betreft" "Het unieke en eenmalige, at ieder mens onderscheldt van een ander, en dat betekenis geeft a an zijn be- 
staan, heeft evenzeer betrekking op creatief werk als op liefde. Wanneer de onvervangbaarheid van een persoon is begrepen, is de weg vrij gemaakt voor de verantwoordelijkheid die een mens heeft voor zijn bestaan en zijn voortbestaan. Een mens die zich bewust wordt van zijn verantwoordelijkheid ten opzichte van een ander, of van een onvoltoold werk, zal nooit in stat $z i j n$ een einde te maken aan zijn leven. Hij kent de reden warom hij leeft en hij zal dus vrijwel alle levensomstandigheden kunnen verdragen" (id, 102).

Ieder mens heeft wel iets, dat zijn leven betekenis geeft, ook al is het niet elk moment aktueel aanwezig. Het is dit heel persoonlijke moment dat in de hulpverlening verwoord en uitgewerkt behoort te worden. "Het gaat niet or de zin van het leven in het algemeen, maar om de specifieke $z$ in van het individuele leven op een bepaald tijdstip" (id.,185).

Dat de mens 'leven' zoekt, makkt hem niet direkt tot patiënt. "Het worstelen met de zin van het leven of het worstelen met de vraag of het leven zin heeft is op zichzelf geen pathologisch verschijnsel" (Frankl 1980,71). "De wil ergens zin aan te geven is het leidende principe van de rijpere volwassene", zegt Frankl eveneens (id.,37). Van belang is dat de mens problemen die niet direkt op het nivo van het genoemale principe lijken te liggen, toch als zodanig wil interpreteren en de hulpvrager op dit "volwassen' nivo benadert. Ten diepste speelt voor Frankl altijd mee, dat de mens een "levensfilosofie" nodig heeft (id., 67).

1.3.2. "De mens zichzelf een vraagstuk".

Ofschoon krisis, snelle veranderingen en levensproblemen tekenend $z i j n$ voor onze tijd en de mens in zijn existentiële vakulim "zichzelf een vraagstuk" (Marcel $1956,1969^{3}$ ) is gewor- 
den, wil dit nog niet zeggen, dat een situatie als de onze uniek is. Altija zijn er tekorten geweest en altijd is er lijden geweest, hoewel de omvang ervan in onze tijd wel bijzonder groot is. In zijn antropologische studie 'Das Problem des Menschen" onderscheidt Martin Buber "Epochen der Behaustheit und Epochen der Hauslosigkeit" en hij zegt hierover: "In den einen lebt der Mensch in der welt wie in einem Hause, in den andern lebt er in der welt auf freiem Feld und hat zuweilen nicht einmal vier Pflöcke, ein zelt aufzuschlagen" (Buber 1947 , 330).

Juist wanneer het oerverband tussen mens en wereld van binnenuit of van buitenaf verbroken wordt, merkt Buber op, ontdekt de mens zich als een eenzame en vreemde. Een dergelijke situatie is ontstaan na het verbreken van het "kosmologisch wereldbeeld" van de oudheid en ook na het verbreken van het "theologisch wereldbeeld" van de middeleeuwen. Vervolgens is het westerse denken een derde grote poging gaan doen om voor het mens zijn zekerheid te bewerkstelligen. Buber spreekt van de "logologische" poging. Rosenzweig makt eenzelfde onderscheid, maar spreekt met betrekking tot het derde tijaperk van "die anthropologische Neuzeit" (Rosenzweig 1937,378).

De pogingen die in onze logologische en antropologische tija tot nu toe zijn gedaan om het mens zijn een bepaald perspektief te geven hebben tot een veelheid van denksystemen en van antropologieën geleid (zie $0 . a$. Landmann $1966,1972^{3}$; Kwant 1979; Bakker 1981), maar ze brachten de mens geen oriëntatie in zijn leven en geen antwoord op de vraag wat het is om mens te zijn. De formuleringen van de grote denksystemen, zoals Van Hegel, zegt Martin Buber, brachten de mens geen "thuis" voor hun leven. Integendeel, de krisis van ons bestaan reikt zeer diep. Buber benoemd hem als de krisis van het vertrouwen in het leven en in het bestaan ajs mens (Buber 1947,444; zie ook Buber $\left.1968,1978^{2}, 272-273\right)$. Kuiper spreekt van een 
vreselijk lot als men zichzelt als stuurloos ervaart in een is zinloos beleefd bestaan (Kuiper $1966,1984^{8}, 238$ )

Zoals Viktor Frankl de vraag naar de betekenis van het eigen bestaan als een houding van volwassenheid waardeert, zo kent ook Martin Buber positieve - Buber spreekt van "antropologische" - waarde toe aan de mens die zichzelf als probleem beschouwt. Tot de antropologische zelfbezinning is namelijk in de eerste plats de zich vereenzaamd voelende mens geneigd en in staat, zegt Buber. En hij vervolgt: "der Mensch also, der seiner Art nach oder seinem Schicksal nach oder beiden nach mit sich und seiner Problematik allein ist und dem es in dieser ausgesparten Einsamkeit gelingt, sich selbst $z u$ begegnen, in seinem eigenen selbst den Menschen und in seiner eigenen Problematik die menschliche Problematik zu entdecken" (Buber 1947,330 ).

Er zit echter ook een risiko aan de situatie van de eenzame mens. In zijn besluiteloosheid kiest hij, voor wat Buber en ${ }^{\text {Rosenzweig "het }}$ Niets" noemen (Buber 1968,1978 ${ }^{2}, 273$; Rosenzweig $\left.1921,1976^{4}, 4-5\right)$. Uit angst voor de toekomst. loopt hij het gevaar vanuit $\mathrm{zijn}$ beleving van eenzaamheid en vervreemding en tegen de achtergrond van "de geschonden totaliteit van de mens" (Buber id.,273), de toekomst te ontvluchten. "Fen geslacht nu dat het heden ontvlucht uit angst dat er geen toekomst zal zijn, kan onmogelijk een volgend geslacht opvoeden" (Lasberg 1980,14). Met andere woorden: een dergelijk geslacht kan onmogelijk gezond leven doorgeven. Dasberg: "De pedagoog moet bij zijn invoering van kinderen in de wereld deze wereld niet alleen pedagogisch vertalen, hij moet er zelf in geloven. Hij moet voor zichzelf helderheid hebben, en dat ook kunnen overdragen, volgens wellke waarden en normen het hopen op de toekomst gerechtvaardigd is. Angst voor hel en verdoemenis heeft mensen nog nooit fatsoenlijker gemaakt. Integendeel, ra- 
deloosheid leidt tot agressie en destructie. Er bestaat geen andere pedagogie dan de pedagogie van de hoop". Wat voor de pedagogie opgaat gaat ook op voor andere situaties warin leven en toekomst aan de orde zijn, zoals in de hulpverlening, de geneeskunde, en de gezondheidkunde.

Dasberg sluit af met de volgende aan Reamer ontleende woorden: "Our job is not only convincing people why not to die, but more important why to live" (id.,29).

1.4. Verantwoording.

Vraagstelling.

Gezondheid en genezen zijn ingebed in een antropologische kontekst en gezondheidsproblemen zijn - ook als het een lichamelijke klacht, ziekte of gebrek betreft - tevens levensproblemen. Kenmerkend voor onze westerse kultuur is, dat een antropologisch perspektief als oriëntatie voor leven, en daarmee ook voor genezen en voor gezondheid, ontbreekt. Frank 1 spreekt van een "existentieel vaculim" Buber van een "krisis van het vertrouwen" en sperna Weiland van een "breuklijn in de geschiedenis".

B1j ons zoeken naar leven en naar gezondheid en genezing in de meest ruime zin, kunnen wij in onze snel veranderende samenleving nauwelijks nog steunen op de traditionele waarden van onze kultuur. Juist op dit punt is er sprake van een vertrouwenskrisis en juist hier ligt de breuklijn. Dit antropologisch vakuium vraagt van ons een zoeken naar een geheel nieuwe levensoriêntatie.

Het is mogelijk te trachten dit, los van alle traditie, te doen op basis van individuele belevingen en gedachten. Ook bestaat de moge- 
lijkheid naar de ervaringen en het gedachtengoed te kijken van andere kulturen en tradities dan de christelijk-humanistische traditie waaruit wij voortgekomen zijn. Maar er is nog een derde weg en deze ligt in het (weer) leren kennen van het oorspronkelijk aan onze kultuur ten grondslag liggende weten en in het verbinden van onze ervaringen nu met de in dit weten opgeslagen levensregels. Met name denk ik, zoals gezegd, aan de leef-en denkwereld van de joodse traditie. In deze traditie zijn leven. overleven, overleveren en gedenken van de allerhoogste warde. Het is deze traditie die tot in alle facetten van haar bestaan en in alle aspekten die a an het leven te onderscheiden zijn "een bevestiging van het leven" (Schindler 1982-1983,15) inhoudt.

In deze studie wil ik enkele basisgedachten en -karakteristieken uit het joodse weten onderzoeken en presenteren als oriëntatie voor leven en voor mens zijn. Het betreft een literatuurstudie waarbij het gaat om een exploratie en een interpreterende verheldering van de joodse traditie als relevant voor "leven". Ik hoop hiermee tevens aan te tonen, dat het om een genees- en gezondheidkundig - en dit in zijn meest ruime, antropologische kontekst belangrijke zaak gaat.

Ik kom nu tot deze formulering van de vraagstelling: Wat kan de joodse traditie met haar antropologische gerichtheid en haar hoge wardering voor mens zijn en voor leven bijdragen aan de genees- en gezondheidkundig relevante vraag naar levensorièntatie?

De vragen die op basis hiervan om beantwoording vragen, zijn:

- wat houdt de joodse traditie (joodse kultuur, denken en weten, ervarings- en gedachtengoed, wetenschap, literatuur) in?

- in hoeverre is zij van betekenis voor gezond mens zijn en geeft zij antwoord op de vraag 'als je leven zoekt"? Met andere woorden: geeft de joodse traditie een antropologisch 
relevante oriëntatie aan het verlangen naar gezond (heel) mens zijn?

- geeft de joodse traditie ons een antropologische relevante oriëntatie voor ons doen en laten in de gezondheidszorg?

In het besef dat volledige transparantie (Levinas, bij Goud 1983.49) onmogelijk is, werk ik in deze studie niet toe naar een bepaalde bewijsvoering of naar een bepaalde konklusie en stellingname. Fvenals dit voor be Geus in zijn dissertatie opgeld deed, is de gehele studie "een aanbieding van gegevens en gedachten" aangaande het leven dat aan de vraag naar gezondheid en genezen ten grondslag ligt en in deze zin is het eveneens "een overpeinzing bij een crux medicorum" (De Geus $1970,162)$. De te presenteren descripties "berusten op een ander 'bewijs' dan uw insteming met de beschrijving" (Levinas, bij Goud 1983, 51 ).

1.4 .2 . Autobiografische verantwoording.

Van wetenschappelijk onderzoek wordt wel gezegd, onder andere door Schelsky, dat het kan beginnen bij "de primaire sociale ervaring van iedereen" (Hartmann 1973,41). Onder primaire sociale ervaring wordt verstaan de persoonlijke ervaring in en met betrekking tot de werkelijkheid warin wij leven. Ook a an deze studie ligt een dergelijke ervaring ten grondslag.

Aanvankelijk was ik als matschappelijk werker werkzaam in een gezondheidscentrum (zie o.a. Lamberts 1970; Lamberts en Op 't Root 1970:Op 't Root 1974; Riphagen 1980). Dat de mensen geen leven hebben leerde ik uit ervaring kennen. Daar lets aan te doen bleek al spoedig veel ingewikkelder te zijn dan ik a anvankelijk dacht en hoopte. Ik besloot tot verdere studie in de nog jonge wetenschap van de andragogie. Deze keuze leidde tot een konfrontatie met de vraag naar de aard en de strekking van mense- 
lijk leven en - meer andragologisch relevant met de vraag naar de aard en strekking van de andragogische situatie als een situatie van mensen in relatie tot elkaar. In het verband van een kleine leergroep lieten we ons in studie en gesprek door de volgende uitgangsstelling leiden: "dat de mensen geen leven hebben, dat 'anderen' menen dat daar iets aan te doen is - ziedaar de aanzet van de andragogische praxis. Ziedaar ook een eerste, kort begrip van de andragogie: de andragogie is dat 'iets', zou dat 'iets' kunnen zijn. ziedaar ten laatste waar de andragoloog over na te denken heeft" (Warmenhoven 1972, 254).

Dit nadenken gebeurde diepgaand. Het bracht ons onder andere in kontakt met het leven en werk van een aantal filosofen, die met betrekking tot de vraag naar het leven en naar wat het is om mens te zijn, een en ander te zeggen bleken te hebben: Walter Benjamin, Martin Buber, Eugen Rosenstock-Huessy, Franz Rosenzweig, Emmanuel Levinas, e.a. Na enige tijd viel het me op, dat de meesten van hen joden waren en/of op de een of andere wijze met joodse konsepten werkten en hier betekenis aan hechtten. In de veronderstelling, dat dit weten relevant zou zijn voor het leven van mensen en voor de hulpverlening besloot ik mij verder te verdiepen in het joodse gedachtengoed.

ook in mijn latere werk bij de huisartsopleiding en in mijn kontakt met huisartsen bleek de behoefte an fundamentele verdieping met betrekking tot de vraag naar gezond (= heel) mens zijn en naar oriëntatie met betrekking tot het leven groot. Deze vragen blijken overigens veelal gepaard te gaan met de behoefte aan en de vraag naar een direkte, op korte termijn inzetbare, handelingsbekwaamheid.

De mens moet handelen. Hij kan niet anders. Zijn bezigheid dient ertoe deze wereld beter achter te laten dan toen hij erin kwam (schindler 1982-1983,5). Dit menselijk bezig 
zijh heeft in vele vormen in onze kultuur uitarukking gevonden onder andere in de (huisarts)geneeskunde. Hiervoor zijn allerlei vaardigheden noodzakelijk, maar tegelijk ook is bezinning op de oriëntatie van deze varaigheden, waarvan in elk geval gezegd kan worden, dat ze op gezond leven gericht zijn een vereiste. Aan deze vraag naar bezinning, hoop ik met dit onderzoek een bijdrage te kunnen leveren.

$1 \cdot 4 \cdot 3$. Wetenschappelijke verantwoording.

In tweeledig opzicht is deze studie inleidend en explorerend van karakter. Allereerst stat zij los van een gangbare wetenschappelijke school of traditie. Zij beweegt zich niet binnen een bepalde wetenschappelijke richting, model of stramien. Voorts is deze studie inleidend en explorerend van karakter, aangezien zij niet strikt an een bepald vakgebied gebonden is of vandaar vertrekt. Ik beoog niet mij binnen het vakgebied van de judaica te begeven. Fen interne diskussie binnen dit vakgebied is hier niet aan de orde. Ook gaat het hier niet on wijsgerige antropologie en geneeskunde in de gangbare uitingen. Wel beoog ik een bijarage te leveren aan een antropologische orientatie met betrekking tot gezondheid en genezen.

Mijn bedoeling is het aanbieden van gegevens en gedachten yoor het leggen van verbindingen en het tonen van een samenhang tussen een aantal basisgedachten van het joodse weten (joodse traditie, Torah) en eigentijase antropologisch-gezondheidkundig relevante situaties. Ik beoog de relevantie van het joodse weten aan te tonen met betrekking tot de aktuele levenssituatie van de mens, meer specifiek zijn gezond bestaan in de meest ruime zin. Als zodanig is er letterlijk sprake van een verkenning of in meer gangbaar-wetenschappelijke 
termen: van een explorerende studie (vgl.Vercruijsse 1970,114-115:Gadourek 1972,101).

Het exploratief onderzoek, zoals De Groot dat omschrijft in zijn boek 'Methodologie', is vooral gericht op het vinden van bepalde soorten samenhangen die uiteindelijk moeten leiden tot het vormen van hypothesen. Een onderzoek als dit, dat niet alleen op het vinden en aandulden van samenhangen gericht is mar vooral ook het "verkennen van een veld" is, zou De Groot wellicht 'descriptief" noemen. De Groot wijst er overigens op, dat een type-indeling willekeurig is. zo zegt hij, dat het onderscheid dat hij aanbrengt tussen onder andere descriptief en exploratief onderzoek lang niet ${ }_{5}$ altijd gemakt wordt (De Groot 1967 . $\left.1970^{5}, 316-324\right)$.

Er valt veel voor te zeggen het verkennen van een bepald gebied, zoals hier aan de orde is, exploratief onderzoek te noemen. Het gaat om het exploreren van betrekkelijk onbekende gegevens. Er is sprake van een breed gebied, warbij een veelheid van gegevens eerst moet worden onderzocht en dan beschreven.

Het gat in deze studie niet alleen om kennisvermeerdering, maar ook om kennisopdelving. Het joodse weten is een zaak die in de werkelijkheid voorhanden is. Het exploreren hiervan gebeurt met het oog op het menselijk gezond bestaan. In deze zin is het opdelven van het weten van de joodse traditie tevens een interpreteren van dit weten met betrekking tot het in deze studie an de orde zijnde thema van leven en gezond bestaan.

In de situatie warvan hier sprake is, wordt de wetenschappelijkheid van het exploreren en interpreteren vooral bepald door "de toegemetenheid aan de zaak" (Loen 1973,12). Kennen is volgens Loen deelhebben aan de warheid van de zaak of van een bepaald zijnde (id.,13; vgl.Levinas, bij Goud 1983,51). In deze studie is de zaak die voorondersteld wordt de joodse traditie en wel in haar relevantie voor het 
leven en voor het gezond (heel) mens zijn.

1.4.4. De opzet van deze studie.

De joodse traditie bevat een enorme veelheid aan teksten, kommentaren en beschouwingen. Bovendien, zo merkt soetendorp op." is ex niet éen wijze waarop Joods geestelijk erfgoed werd doorgegeven; er waren er meer" (soetendorp $1964,34)$. In de joodse 1iteratuur die uitgaat van de op het menselijk leven en de wereld betrekking hebbende Torah, zijn nar ik meen twee hoofdlijnen te onderscheiden: een rabbijnse en een Grieks-westerse, filosofische, lijn. Beide lijnen beogen het gedachtengoed van Torah en Tenach door te geven.

De bekendste en meest uitgebreide vorm is die van het rabbijnse jodendom. Men kan ook zeggen dat het normatieve jodendom zich met name in rabbijnse richting heeft ontwikkeld. De joodse traditie komt hierin als een geheel eigen traditie naar voren. Daarnaast rekenen sommige auteurs het tot hun plicht het bijbelse gedachtengoed in de gangbare Grieks-westerse wetenschappelijke terminologie tot uitarukking te brengen. Dit deden onder andere in de Middeleeuwen Maimonides en in onze tijd Rosenzwelg. Buber en Levinas (zie Goud 1983,55). De filosofische 1 ijn is niet kontinu van karakter. Er is eerder sprake van een aantal hoogtepunten. Het rabbijnse denken is wel als een meer kontinue stroom op te vatten.

Het is overigens niet zo dat het om twee strikt gescheiden stromingen gat. Fr is een sterke samenhang tussen beide. Rosenzweig en Levinas bijvoorbeeld, en in de Middeleeuwen ook Maimonides, staan niet naast het rabbijnse weten. mat verwoorden dit weten in filosofische termen. $\mathrm{zij}$ doen dit in de hoop dat op deze wijze het joodse weten in de gangbare kultuur beter verstaanbaar wordt. 
Veel van het rabbijnse gedachtengoed is in het Hebreeuws en in het Aramees geschreven. Een aantal van de belangrijkste teksten en kommentaren is vertald in het Duits en het Engels. De duitstalige literatuur stamt hoofdzakelijk uit de tijd vóór 1933, mar de laatste jaren is de in het Duits geschreven literatuurstroom weer op gang gekomen. Vanaf de vorige eeuw zijn veel vertalingen in het Engels verschenen. Ook veel verhandelingen over het jodendom zijn engelstalig. Op bescheiden schaal zijn teksten, kommentaren en verdere literatuur in het Nederlands beschikbaar (zie smelik 1983). Behalve van vertalingen was ik ook genoodzaakt gebruik te maken van zogenaamde sekundaire literatuur. Dit is literatuur die handelt over het joodse weten en die joodse teksten en kommentaren vaak op een eigen wijze verwerkt. Persoonlijk beschouw ik dit in het kader van deze studie niet als een bezwaar. Overigens acht ik het ook principieel geen bezwar, zolang het om door het joodse gedachtengoed geInspireerde literatuur gaat, dat wil zeggen om literatuur die in direkte samenhang met het joodse weten geschreven werd en dit ook bedoelt te zijn.

Met betrekking tot de veelheid aan literatuux heb ik me zoveel mogelijk laten leiden door een antropologisch-gezondheidkundig relevante richtingbepaling. Bij mijn literatuur-onderzoek heb ik echter geen hedendaagse studie aangetroffen die vanuit de in onze tijd belangrijke antropologisch-gezondheidkundige gezichtshoek een verwijzing naar en een inzicht in de joodse traditie kan geven. Er zijn wel inleidingen met betrekking tot het jodendom beschjkbaar. Ik noem dje van zuidema $\left(1976,1982^{4}\right)$, Baeck $\left(1906,1926^{4}\right)$, Cohon (1971) Epstein $\left(1954,1980^{6}\right)$, Grünewald $\left(1970_{3}\right)$, Heschel $\left(1955,1976^{3}\right)$, Hurwitz $\left(1978,1981^{3}\right)$, Jakobovits (1977), Kaplan (1979). Schalom BenChorin $\left(1975,1979^{2}\right)$. ook noem ik het twintigdelige standaardwerk 'Encyclopaedia Judaica' 
$\left(1972,1978^{4}\right)$, dat artikelsgewijze de verschillende aspekten van het joodse weten behandelt. voor een overzicht van het joodse gedachtengoed in historisch perspektief verwijs ik naar Stemberger (1977) en naar seltzer (1980). Nast deze meer algemene inleidingen kent de joodse traditie ethische richtlijnen met betrekking tot diverse geneeskundig en gezondheidkundig relevante problemen (abortus, euthanasie, e.d.). Ik noem hier de publikaties van Abraham (1980), Bleich, (1977), Bleich (1981), Feldman $\left(1968,1978^{3}\right)$, Friedenwald (1969), Jakobovits (1975), Rosner (1972) en Rosner/Tendler (1980) Voor één onderzoek vraag ik apart uw aandacht, namelijk de onderwijskundig-filosofische studie én inleiding tot het joodse denken en weten: "Joodse traditie als permanent leren". Hierop promoveerde I.B.H. Abram in 1980 bij A.D. de Groot (Abram 1980). Vanuit de 'education permanente' als invalshoek geeft Abram in zijn boek inzicht in de joose traditie als een traditie van permanent leren. Ik zou deze studie in alle opzichten 'voorbeeldig' willen noemen.

waar de tekst van de Hebreeuwse bijbel ter sprake komt, laat ik zoveel mogelijk de'gesproken-woord" vertaling van het Hebreeuws in het Duits horen, die Martin Buber samen met Franz Rosenzweig in 1925 begonnen is en die hij na het overijjaen van zijn mede-auteur in 1929 alleen voortgezet heeft (Buber/Rosenzweig - Die schrift). In deze vertaling komt het koJoriet van de joodse traditie duidelijk hoorbaar natr voren. En de vertaling op zich geeft al een inleiding op het joodse gedachtengoed (zie ook hoofdstuk 2). "Tot dusver blijft alléen deze "Schriftverdeutschung" zodanig trouw a an het hebreeuws" zegt De Miranda die in zijn dissertatie eveneens deze vertaling gebruikte, "dat de tekst ook in de vertaling nog in aanzienlijk mate 'zichzelf verklaart'. De zoals Buber uiteenzet - bij onbevangen lezing uit de tekst zèl naar voren komende zinduiding, die veelal beter terzake voert dan welk 
analyserend of theologiserend kommentaar, heeft in mijn studie voortdurend vooropgestaan" (De Miranda 1979,8; zie id."1983,7-8, 188).

Wat betreft de opzet van deze studie nog het volgende: de weg naar het joodse denken en weten zette voor mij persoonlijk in met een globale oriëntatie in de filosofisch-joodse literatuur van deze eeuw. Hierbij bleek dat vooral Franz Rosenzweig in alle scherpte de aard en betekenis van de joodse traditie tot leven heeft gebracht. Dit leidde ertoe dat ik mij in eerste instantie op diens werk ging konsentreren. In het tweede hoofdstuk leg ik hiervan verantwoording af. Hiermee presenteer ik Rosenzweig tevens eksemplarisch als vertegenwoordiger van de filosofisch-joodse lijn. In het derde hoofdstuk ga ik in op de rabbijnse traditie die rond de Torah gestalte heeft gekregen. Rond de termen gezondheid en genezen en gezondheidkunde en geneeskunde ga ik in het vierde hoofdstuk verkennen wat hierover in het joodse weten werd en wordt gezegd. In het vijfde hoofdstuk wil ik aan de hand van enkele, met name voor de huisartsgeneeskunde relevante konsepten een verbinding leggen met de joodse traditie. Ik hoop hiermee aan te tonen dat in de kontinue stroom van de joodse traditie en literatuur konsepten aanwezig zijn die aktueel en relevant zijn voor het leven van de mens en daarmee voor genees- en gezondheidkunde. In het zesde hoofdstuk geef ik vooral die aantekeningen weer die betrekking hebben op de mens en op zijn (gezond) leven als (heel) mens. Met dit joods-antropologische hoofdstuk sluit ik tevens deze studie af. 
HOOFDSTUK 2: FRANZ ROSENZWEIG:

VERTEGENWOORDIGER VAN HET

FILOSOFISCH-JOODSE WETEN.

$2 \cdot 1$.

Inleiding.

In het eerste hoofdstuk heb ik een onderscheid gemaakt tussen de literatuur van het rabbijnse jodendom en het in filosofische bewoordingen gestelde joodse weten. Voor het rabbijnse jodendom is kenmerkend dat het op een geheel eigen en bijzondere manier er zorg voor draagt de betrekking tussen de mens en Gods Torah overal en altijd te realiseren (zie hoofdstuk 3). Het filosofisch-joodse weten darentegen weet zich meer gebonden door de overheersende denkstromingen van bepaalde tijden en plaatsen. Kenmerkend is dat de uitwerking van het gedachtengoed van de Hebreeuwse bijbel en van de verdere literatuur in de gangbare Griekswesterse terminologie gebeurt.

In het fllosofisch-joodse weten gat het om filosofie, terwijl datgene wat tot uitdrukking wordt gebracht toch authentiek joods is. Inhoudelijk betreft het dezelfde konsepten als in de rabbijnse traditie. Franz Rosenzweig heeft ooit opgemerkt, dat de talmoedisch-rabbijnse literatuur de encyclopedie van het levende jodendom is, maar dat de filosofische literatuur de fijnste sublimering ervan is (Rosenzwelg 1937,57). Zij laat het gedachtengoed op een geheel eigen wijze zien en makt het voor veel mensen op een geheel eigen wijze verstaanbaar. De filosofisch-joodse literatuur beoogt bovendien het verwerpen van die werelden levensbeschouwingen en van die leerstelsels die strijaig zijn met het joodse denken en de joodse levenspraxis (Hyman 1980,209). De filosofen Rosenzweig en Levinas doen dit zo indringend, dat zij de gehele westerse traditie 
en wijze van denken ter diskussie stellen (De Boer 1976,$11 ; i d ., 28 ; i d ., 121-136)$. In een interview merkte Levinas op dat het authentiek joodse in westers-filosofische termen, dat wil zeggen in de taal en terminologie van de gangbare kultuur verwoord moet worden, wil het gehoord worden en doorwerken (Levinas, bij Goud 1983,55). Levinas acht dit zijn levensopdracht. Ik meen echter, dat ook de rabbijnse wijze van weten, voor degene die zich de moeite neemt deze te leren kennen, verstaanbar wordt en positief op iemands geestelijke gezondheid en gedrag kan doorwerken.

De filosofisch-joodse literatuur is ontstan in de gehelleniseerde joodse gemeenschappen van de tweede eeuw vór onze jaartelling. zij kende in die tijd gedurende ongeveer een eeuw een betrekkelijke periode van bloei. Een tweede hoogtepunt kwam tot stand in de Europese Middeleeuwen met uitlopers tot in de zestiende eeuw. De moderne joodse filosofie, de derde periode, begon met de Verlichting. Deze bracht ook voor de joden de emancipatie, althans in West-Europa. De Hebreeuwse term voor deze joodse verlichting is "haskala'. De opbloei is begonnen in de tweede helft van de achttiende eeuw en duurt tot nu toe (Enc.Jud., Vol.13,421465; Hyman 1980, 209-216).

Een van de meest bekende joodse filosofen uit de oudheld is Philo van Alexandriè. Hij leefde rond het begin van onze jaarteling. Uit de Middeleeuwen is Mozes Maimonides (1135-1204) het meest bekend. In het vierde hoofdstuk zal ik aan hem aandacht besteden, echter niet zozeer in zijn kwaliteiten van talmoedgeleerde en van filosoof, maar vooral in verband met zijn gezondheidkundige opvattingen. Wat de expliciete aandacht voor joodse filosofen betreft, beperk ik mij tot onze eeuw. Een van hen, Franz Rosenzweig, zal ik in dit hoofdstuk bespreken. Voor een overzicht van de joodse filosofie verwijs ik naar 4'Philosophies of Judaism'. (Guttmann $1964,1976^{4}$ ). 
In de Eilosofische literatuur van deze eeuw valien, bij nadere studie, de namen op van drie auteurs die het joodse denken tot bron en grond van hun filosoferen hebben gemakt: Franz Rosenzweig (1886-1929), Martin Buber (1878-1965) en Emmanuel Levinas (geb.1906). Rosenzweig en Buber zijn beiden afkomstig uit een aan de Europese kultuur geassimileerd joods milieu. Hun kritische bezinning op deze kultuur en de vraag naar hun mens zijn bracht hen terug bij de joodse traditie. Deze bezinning werd mede ingegeven door de krisis waarin het Europese denken in de loop van de vorige eeuw en het begin van deze eeuw was terecht gekomen, een krisis die gepaard ging met veranderingen op allerlei gebied: sociaal, ekonomisch, op het gebied van de kunst en de godsdiengt (zie 0.a. Bochenski 1952,26-27; Buber $\left.1973^{3}, 301-310\right)$.

Aanvankelijk onafhankelijk van elkaar, maar later hecht samenwerkend, verwoordden Buber en Rosenzweig een nieuwe vorm van denken: het dialogische denken. In dezelfde richting dachten anderen als Ferdinand Ebner (Ebner 1921; zie ook Casper 1967) en met name ook de nogal eigenzinnige sociaal-filosoof Eugen Rosenstock-Huessy, vriend en diskussiepartner van Franz Rosenzweig (zie o.a. Hasselaar 1973). Ik noem Rosenstock-Huessy hier mede, omdat ik via diens werk op het spoor werd gezet van het denken van Rosenzweig (zie verder Schrey 1970 en Theunissen $1965,1977^{2}$ ).

De dertiger jaren en de Tweede wereldoorlog waren in zekexe zin een breekpunt voor het in het Duits taalgebied tot ontwikkeling gebrachte dialogische denken. Ebner raakte in vergetelheid. Rosenzweig overleed, op nog jonge leeftijd, in 1929. Rosenstock vluchtte in 1933 naar de verenigde staten en Buber moest in 1938 naar het toenmalige Palestina vertrekken. Als 'school' kon het dialogische denken mede hierom niet tot ontwikkeling komen en kon het "de filosofie' nauwelijks beroeren. Wel rakte 
dit nieuwe denken veel mensen in het hart en werd het tot troost van velen in de donkere jaren waarin mens zijn en menselijke waraigheid volstrekt niet meer telden. Vooral Martin Buber had met zijn chassidische verhalen (Buber 1927) en zijn dialogische geschriften (Buber $1973^{3}$; zie ook Buber 1936) invloed op veel mensen, ook in Nederland (Beek en Sperna Weiland 1964;Waaijman 1976; Sperna Weiland e.a. 1978).

Franz Rosenzweig was eigenlijk alleen bij een aantal insiders bekend geworden en dan nog alleen binnen het jodendom. Toch heeft Miskotte in zijn proefschrift in 1932 al over hem geschreven (Miskotte $1932,1964^{2}, 278-370$ ). Na de oorlog wezen in Nederland vooral Breek en Heering op de betekenis van het werk van Rosenzweig (Breek 1972; Heering 1974;id.,1976). In de Verenigde Staten presenteerde Glatzer in 1954 een studie over Rosenzweig (Glatzer 1953, 1972), terwijl het hoofdwerk "Der stern der Erlösung' en enkele andere geschriften werden vertaald. In Israël zorgde Yehoshua Amir, die ook in het Duits over Rosenzweig publiceerde (Amir 1979), voor een vertaling van het hoofdwerk. In Duitsland werd in 1933 een boek van Else Freund over Rosenzweig gedrukt, dat echter om politieke redenen niet mocht verschijnen. In 1959 verscheen het boek in gewijzigde vorm (Freund 1959). Verder noem ik de boeken van Tewes (1970) en van Veith (1973). Fen uitstekende inleiding tot Rosenzweig biedt Mayer (1973). In Frankrijk doet het verheugende feit zich voor, dat Rosenzweig hier recent in de belangstelling is komen te staan (Petitdemange 1979; Mosès 1982). De invloed van Levinas, aan wiens werk het denken van Rosenzweig ten grondslag ligt, is hieraan niet vreemd.

De derde auteur die naast Buber en Rosenzweig van groot belang is en wiens filosofie specifiek joods van karakter is, is de hiervoor genoemde, in Parijs werkzame, Emmanuel Levinas. (zie 0.a. Levinas 1969,19712; De Boer 1976; 
Strasser 1978$)$.

Buber "Rosenzweig en Levinas zijn niet alleen van joodse afkomst, maar zij hebben ook de inzichten van het joodse weten als bron van het bestaan erkend en daadwerkelijk bevestigd. Bovendien hebben zij deze inzichten tot grond van hun werk gemaakt. Het werk van ieder van hen heeft een eigen karakteristiek. Buber is meeslepend en veelzijdig. Rosenzweig scherpzinnig en systematisch. Levinas is subtiel en schokkend. Meer dan de veelzijdige Buber en de moeilijk toegankelijke Levinas is het Rosenzweig geweest die mij een introduktie gaf tot het joodse denken en die mij persoonlijk aansprak. Het veranderde niet alleen mijn eigen mens zijn en de beleving daarvan, maar ook mijn zicht op het menselijk bestaan en het denken hierover.

Mede hierom heb ik ervoor gekozen in deze studie het leven en werk van Franz Rosenzweig exemplarisch als inleiding tot het filosofisch-joodse gedachtengoed te presenteren. De keuze voor Franz Rosenzweig is niet alleen op biografische gronden gebeurd, maar zij is ook ingegeven vanwege het feit dat ik Rosenzweig nog tot de eigentijdse denkers zou willen rekenen. Horwitz noemt hem "one of the geniuses of modern Jewish thought" (Horwitz 1978, 240). Rosenzweig voelde de krisis van de westerse kulturen in alle scherpte aan en hij heeft een perspektief willen geven. Toch is hij in de wijze warop hij zijn inzichten verwoordt en in zijn woordgebruik iemand van zestig-zeventig jaar geleden. Maar ondanks het soms wat hoogdravende taalgebruik getuigt zijn woord van een grote kracht en geinspireerdheid. Ik hoop dat $U$ hier oog, maar vooral "oor' voor hebt. De nogal gedragen taal is een bezwaar dat bij voldoende inleving in elk geval wegvalt.

Voor zover de gezondheidsbeleving en de beleving van mens te zijn mede afhangt van de mogelijkheid, de moed en de wil om voor het 
eigen mens zijn verantwoordelijk te zijn en dit te durven interpreteren en te leven, moet ik de keuze voor een nadere uitwerking van de levensweg en het werk van Franz Rosenzweig eveneens positief beargumenteren. Rosenzweig heeft voor grote beslissingen gestaan en hierin niet voor de dood mar voor het leven gekozen (vlg.Deut.30:15-20: Rosenzweig 1921. $\left.1976^{4}, 3 ; \mathrm{id} .472\right)$. Tijdens zijn langdurige ziekte stond voor hem niet de naderende dood centraal, maar het leven. Een bezoeker moet in die tijd eens gezegd hebben: "Nie habe ich einen gesünderen Menschen gesehen" (Simon 1930, 37). En een andere bezoeker schreef over zijn ontmoeting met de zieke Rosenzweig: "Hier herrschte keine Not, kein Druck, sondern völlige Freiheit" (Rosenzweig 1979, Bd.2,1108). Er is nog een laatste argument waarom het alleszins verantwoord is juist Rosenzweig als vertegenwoordiger van het filosofisch-joodse weten hier naar voren te halen. Binnen het jodendom kreeg $\mathrm{zijn}$ werk erkenning, doordat hem officieel de wardigheid en titel van 'onze leraar' werd verleend. Deze 'kroon van het rabbinat' ontving Rosenzweig op 26 juni 1923 uit handen van de rabbijn en hoogleraar Leo Baeck. Met dit argument wil ik aangeven dat Rosenzweig niet gezien moet worden als een filosoof die los staat van de joodse traditie (zie hoofdstuk 3). Integendeel: hij kreeg van rabbijns-joodse zijde erkenning.

Een eerste korte oriëntatie in het dialogisch denken aan de hand van Franz Rosenzweig leert, dat dit denken af wil van het bouwen van denksystemen en van het bezig zijn met de vraag naar het wezen van al het zijnde. Rosenzweig wil zich baseren op de werkelijkheid zoals iedere mens deze ervaart. "Alle Philosophie frug nach dem 'Wesen'. Es ist diese Frage, mit der sie sich vom unphilosophischen Denken des gesunden Mensenverstands scheidet" "zegt Rosenzweig in een van zijn meest bekende artikelen, 'Das neue Denken" (1925). En hij vervolgt: 
"Der (= het gezonde verstand) fragt nicht was ein Ding 'eigentilch' sei. Es gentigt ihm, zu wissen, dass ein Stuhl ein stuhl ist; er fragt nicht, ob er etwa eigentlich ganz etwas andres ware. Eben dies fragt Philosophie, wenn sie nach dem wesen fragt. Die welt darf beileibe nicht Welt sein, Gott beileibe nicht Gott, der Mensch beileibe (bei-Leibel-J.R.) kein Mensch, sondern alle mússen 'eigentlich' etwas ganz andres sein" (Rosenzweig 1937,377).

Rosenzweig vindt dat het denken niet naar het wezen, maar naar het 4 leven behoort te vragen (Rosenzweig $1921,19764,342$ ). Hij wil vertelien over hoe de verhoudingen tussen God, de wereld en de mens liggen. Hij geeft an dat er sprake is van wederkerige betrekkingen tussen God en de wereld, tussen God en de mens en tussen de wereld en de mens. Juist deze betrekkingen tussen God, de wereld en de mens ervaren wij. "Denn in der wirklichkeit, die wir einzig erfahren, wird sie (de scheiding in drieën $-J \cdot R$.$) liberbrückt und alles, was wir erfahren,$ sind Erfahrungen solcher Brückenschläge. Gott selber, wenn wir ihn begreifen wollen, verbirgt sich, der Mensch, unser selbst, verschliesst sich, die Welt wird zum sichtbaren Rătsel. Nur in ihren Beziehungen, nur in Schöpfung, Offenbarung, Erlösung tuen sie sich auf" (Rosenzweig 1937,386).

Met name in 'Der Stern der Erlosung' heeft Rosenzweig deze filosofie uitvoerig uitgewerkt. Ik vertel eerst iets over de levensgeschiedenis van Rosenzweig. Dan besteed ik aandacht aan' "Der Stern' om in een laatste paragraaf weer aan de hand van biografische data het verhall over Rosenzweig en zijn werk te komplementeren.

Een stukje levensgeschiedenis.

Franz Rosenzweig werd op 25 december 1886 in Kassel geboren. Zijn ouders behoorden tot de 
zogenaamde geassimileerde Duitse joden. Dit wil zeggen dat zij zich niet zozeer door hun jood zijn lieten leiden, maar hun identiteit vooral zochten in de Duits-Europese kultuur. Rosenzweigs moeder schijnt in had hart wel een zekere affiniteit met het jodendom bewaard te hebben.

Tot de familie Rosenzweig behoorde ook nog een inwonende oom van vaderszijde: Adam Rosenzweig (1826-1908). Deze oom was trouw gebleven aan bepalde vormen van het traditionele jodendom. over hem bestaat het volgende verhaltje, dat, alhoewel sterk anekdotisch, toch betekenis heeft: toen de jonge Franz op zesjarige leeftijd voor het eerst naar school ging, pakte deze oom hem stevig bij de schouders vast en "fluisterde" hem 'hardop' in het oor: "Junge! heute gehst du zum erstenmal unter die Leute; vergiss in deinem ganzen Leben nie, dass du ein Jude bist" (Prager 1930,39; Rosenzweig 1979, Bd.1,2). In één versie wordt hier nog aan toegevoegd: "Entziehe Dich nicht Deinem Volke!" (Badt-Straus 1930,5).

$\mathrm{Na}$ de basisschool bezocht Franz Rosenzweig het Friedrichs Gymnasium in zijn geboortestad Kassel. In 1904 ging hij, enigszins onder dwang van zijn vader, medicijnen studeren. Deze studie 'om den brode", zoals hilj haar eens noemde, hield hij drie jaar vol. Intussen hadden de kultuurgeschiedenis en de filosofie hem zo in de ban gekregen, dat hij van studie veranderde. Van 1907 tot 1912 studeerde Rosenzweig in Freiburg im Breisgau en in Berlijn. Hij ging zich in het bijzonder voor Hegel en de idealistische filosofie interesseren. In 1912 sloot hij zijn studie af met een promotie bij Friedrich Meinecke in Freiburg. Hij deed dit op een werkstuk dat hij eerst later, in 1920, in een meer uitgewerkte vorm publiceerde. In de geschiedenis van de westerse filosofie heeft Rosenzweig hoofdzakelijk enige bekendheid gekregen met dit werk en met een verhandeling uit 1914: "Das älteste systemprogramm des deutschen Idealismus" (Rosenzweilg 1937. 
230-277). De echte Rosenzweig bleef onbekend. Immers: "Judaica non leguntur, joodse geschriften worden niet gelezen", merkt Heering in de inleiding van zijn boekje over Rosenzweig op (Heering 1974,1).

Rosenzweig voerde reeds in zijn studietijd diepgaande gesprekken, ondermeer met zijn neven Hans en Rudolf Ehrenberg, met de reeds genoemde Eugen Rosenstack en met Viktor von Weizsäcker. De laatste zou later bekend worden door zijn werk op het gebied van de antropologische geneeskunde. De gesprekken gingen over geloof en wetenschap, over kultuur en geschiedenis. De deelnemers waren sterk persoonlijk betrokken bij de ontwikkeling van de Europese kultuur. De gedachte overheerste dat het christelijke Europa en met name het Duitse kultuurgebied toonaangevend voor de geschiedenis van de mensheid was. Eugen Rosenstock, die van joodse afkomst was, koos principieel voor het christendom. Ook Hans en Rudolf Ehrenberg hadden zich laten dopen. BeInvloed door de gesprekken en door het beeld van de geschiedenis kwam ook Franz Rosenzweig steeds meer onder druk te staan dat hij christen behoorde te worden.

In de avond en nacht van 7 juli 1913 vond in Leipzig een lang gesprek plaats tussen Rudolf Ehremberg, Eugen Rosenstock en Franz Rosenzweig. Het gesprek verliep zo, dat ook Franz Rosenzweig de beslissing nam in principe christen te worden. Wel stelde hij dat hij als jood - toch ook een gelovige - tot het christendom wilde overgaan. Rosenzweig wenste niet gedoopt te worden alsof het om een heiden zou gaan. Verder wilde $h i j$ in het najaar nog één keer de grote joodse feestdagen, ook de 'tien dagen van ommekeer" genoemd, van het Joodse Nieuwjaar (Rosj ha-Sjana) tot Grote Verzoendag (Jom kippoer) meemaken. Hij makkte dit voornemen inderdaad war en na de zomer vertrok hij hiervoor nat een orthodoxe joodse gemeenschap in Berlijn. 
Het is nooit bekend geworden wat er toen en daar precies gebeurd is. Wel is duidelijk dat het om iets zeer ingrijpends gegaan moet zijn: Rosenzweig kwam op zijn eerder in Leipzig genomen beslissing terug en koos voor wat hij was: jood te zijn en te blijven. In een brief van 31 oktober 1913 aan Rudolf Ehrenberg sprak hij zich over deze 'oer'-beslissing uit: "Lieber Rudi, ich muss dir mitteilen, was dich bekümmern und, zunächst mindestens, dir unbegreiflich sein wird: ich bin in langer und, wie ich meine, grüdlicher Ueberlegung dazu gekommen, meinen Entschluss zuríckzunehmen. Er scheint mir nicht mehr notwendig und daher, in meinem Fall, nicht mehr möglich. Ich bleibe also Jude" (Rosenzweig 1935,71;id.1979, Bd.1, $132-133$ ).

In een brief die hij een dag later schreef. lichtte Rosenzweig zijn beslissing toe. Kernachtig en scherp verwoordt hij in deze brief zijn positie en situatie als mens en als jood. Als jood verkeert hij in de positie reeds 'bij de vader' te zijn. Het volk Israell is in de situatie dat het Christus hiervoor niet nodig heeft. Dit makt dat het joodse volk tot het einde der dagen een bijzondere positie inneemt (Rosenzweig 1935,73-74; id.1979, Bd.1,135).

In de brief van 31 oktober had Rosenzweig al geschreven, dat het nu ingenomen standpunt in elk geval erkenning verdient - ook van de niet-jood. Hierbij gaat het hem niet alleen om de erkenning van zijn eigen jood zijn, maar ook om de erkenning van het joodse volk en de betekenis van 'het joodse' voor de mens en zijn geschiedenis. Voor de jood ligt deze beslissing anders dan voor de niet-jood. Rosenzweig: "Ums Judentum brauchen wir nicht zu sorgen, das brauchen wir bloss als unser Eigen zu Wissen" (id.,380;id.,Bd.2,658). Rosenzweig ervoer dat het jodendom bij hem persoonlijk hoorde en ook dat het bij de wereld en het mens zijn hoort. "The story of Franz Rosenzweig is the story of a rediscovery of Judaism. An European intellectual and assimila- 
tionlist breaks with his personal past and becomes a Jew by conviction, rediscovers his people's existence, and becomes the modern interpreter of this existence" zo typeert zijn levensbeschrijver Glatzer zeer kernachtig het levensverhal en de ${ }_{5}$ betekenis van Rosenzweig (Glatzer 1953,1972 ${ }^{5}, \mathrm{X}-\mathrm{XI}$ ).

Rosenzweig ging eerst nat Berlijn, war de liberal getinte "Lehranstalt für die Wissenschaft des Judentums" gevestigd was. Aan dit instituut doceerde vanaf 1912 Hermann Cohen joodse wetenschap. Werkelijke kennis leerde Rosenzweig van hem, is geen geisoleerde, dat wil zeggen van de menselijke ervaring losstaande kennis, mar het is juist met de ervaring van mensen verbonden kennis (Rosenzweig $1937,304-305)$. Zoals we in de volgende hoofdstukken nog zullen zien is het joodse weten het prototype van deze kennis.

Bij Cohen kreeg Rosenzweig een ander en nieuw zicht op wat filosofisch denken werkelijk behoort te zijn, namelijk: "Denken, das vom Menschen weiss und das sich dieses Wissen nicht mehr in idealistischem selbstbetrug wieder aus den Fingern gleiten lässt. Denken, das vom Wechselverhältnis von Ich und Du ausgeht, statt wie alles frïhere Denken vom Es oder vom Ich" (Rosenzweig 1937,295-296).

Deze relationele grondstruktuur van de werkelijkheid duidde cohen aan met het woord "Korrelation". Rosenzweig nam dit woord van hem over, overigens zonder het verder in zijn geschriften veel te gebruiken. In 'Der stern der Erlobsung" komt het éên keer voor. Hij noemt het dat "die eigentlich weltanschauungsbegrundende Kategorie der neuen Wissenschaft" (Rosenzwelg $1921,1976^{4}, 246$ ). Met het woord 'korrelatie' brengt Rosenzwelig het gebeuren van mens en wereld in een relationeel perspektief, in een perspektief van betrekkingen, namelijk van "die Wechselverhältnisse zwischen Gott und Welt, Gott und Mensch, zwischen Mensch und Nebenmensch" (Rosenzweig 1937,297; zie ook id.,334 en 338). 
In 1914 ging Rosenzweig in militaire dienst. Deze periode is van belang vanwege het per brief gevoerde joods-christelijk gesprek tussen Rosenzweig aan het oostfront en Rosenstock die in het westen gelegerd was. Rosenstock beschouwde zich als een wijsgerig socioloog die heilig geloofde in een christelijke toekomst voor de mens. Rosenzweig, veel minder zeker nog en minder arrogant, kwam op voor het eigen bestaansrecht en de eigen betekenis van de joodse werkelijkheid. De korrespondentie eindigt hiermee dat Franz Rosenzweig en Eugen Rosenstock elkar vinden in de overtuiging, dat jodendom en christendom beiden zich laten leiden door de openbaring als oriëntering, en dat beiden - alhoewel op een verschillende wijze in de wereld aanwezig - gezamenlijk tegenover het heidendom staan (vgl.RosenstockHussey 1968,21;id.,71). De briefwisseling is als dokument van een hernieuwd begin van de joods-christelijke dialoog beward gebleven (Rosenzweig 1935,635-720;id., Bd.1,189-320; Rqsenstock-Huessy 1968,168-172;id.,1969,1971 ; zie ook Mayer (1966).

2.3 Uit 'Der Stern der Erlösung'.

$2 \cdot 3 \cdot 1$

Inleidende opmerkingen.

Na de in de vorige paragraaf genoemde perioden van scholing en van gesprek was Rosenzweig klaar voor het schrijven van zijn hoofdwerk 'Der Stern der Erlösung'. Nog steeds aan het front, begon hij op veldpostpapier met de voorbereiding en uitwerking ervan. De eerste aanzet voor een komplete dialogische filosofie vinden we in een brief van 18 november 1917 aan Rudolf Ehrenberg. Deze brief met het karakter van een verhandeling, is later als 'Ur- 
zelle des Stern der Erlösung" aangeduid (zie Rosenzweig 1937,357-372).

Alle gebeuren en verandering die de mens ervart, traceert Rosenzweig als 'openbaring'. Het ordeningsbegrip van deze wereld is niet iets neutraals en algemeens, niet een natuurlijke of historische eenheid met een begin en een einde, maar het is een gebeurtenis (id., 365-366). Rosenzweig beschouwt de openbaring als een gebeurtenis die de mens persoonlijk raakt. $\mathrm{Zij}$ vormt het midden van het wereldgebeuren en van de levenswerkelijkheid en als ordening van het leven kun je op haar vertrouwen. "Die offenbarung ist also fähig, Mittelpunkt zu sein, fester, unverrlickbarer Mittelpunkt. Und warum? Weil sie dem Punkt geschieht, dem starren tauben unverschiebbaren Punkt, dem trotzigen Ich, das 'ich nun einmal bin" (id., 366).

Allerlei opvattingen, theorieën, idealen, ideeẽn, imperatieven soms, 1 ijken de mens aan te spreken en proberen hem over te halen en te verleiden: "gib dich mir hinl". De verleiding ligt dan hierin, dat dit kan gebeuren zogenaamd: "aus 'Dankbarkeit', 'freiwillig', auf dass du 'werdest der du bist', deine 'Bestimmung" erfullst - aber jedenfalls: gib dich mir hin!". Stekelig merkt Rosenzweig hierover op: "Voraussetzung also, dass der Mensch sein Eigenes aufgibt". De gebeurtenis van de openbaring doet echter een heel ander appel op de mens, namelijk: "Tue meinen Willen! Wirke mein Werk! Voraussetzung also, dass dem Menschen das Eigene Gottes, Gottes Willen, Gottes Werk anvertraut wird, auf dass er es tue" (id., 366). In zijn 'Urzelle' noteerde Rosenzweig nog: "Das Hochste, statt unsere Hingabe zu verlangen, gibt sich uns selber hin" (id., $366-367$ ).

Als Rosenzweig de openbaring aanmerkt als middelpunt van het hele leven en daarmee van het weten over de mens, wil hij hiermee zeggen, dat de levensbeweging in essentie niet van onszelf, van de natuur c.q. van door ons men- 
sen bedachte systemen kan uitgaan, maar dat zij in werkelijkheid een gebeurtenis met een transcendent karakter is. Het is de beweging van 'God in search of man', zoals Heschel dit uitarukt in de titjel van een van zijn boeken (Heschel $1955,1976^{3}$ ).

Rosenzweig heeft het, het leven ordenend, openbaringsgebeuren, ook tot ordenend beginsel en tot middelpunt van $z i j n$ boek genomen. "Der Stern der Erlösung' bestaat uit drie delen en elk deel bestaat weer uit drie 'boeken'. Het tweede boek van het tweede deel vormt het hart van 'der Stern". De titel hiervan: "Offenbarung oder die allzeiterneuerte Geburt der seele"'. De arie delen heten:

I : Die Elemente oder die immerwährende Vorwe1t;

II : Die Bahn oder die allzeiterneuerte welt; III: Die Gestalt oder die ewige Ueberwelt.

$\frac{2.3 .2 \text { Deel I: "Die Elemente oder die }}{\text { immerwährende Vorwelt". }}$

Rosenzweig heeft elk van de delen van een motto voorzien waarvan de tekst op het besprokene betrekking heeft. Het motto boven het eerste deel luidt: "in philosophos!", tegen de filosofen! Dit heeft betrekking op de kritiek van Rosenzweig op de gangbare wijze van denken en op de inhoud van de filosofie, met name van het idealisme.

De westerse denkers hebben hun ervaren van het "goddelijke". 'wereldlijke' en "menselijke" niet ( $h$ )erkend als betrekkingen tot drie werkelijk aparte zijnden of gegevenheden ('elementen'). Steeds zijn deze ervaringen, al denkend en filosoferend getraceerd tot één "al". één totaliteit, tot één eenheid of tot één essentie van het zijnde. In de antieke, kosmologische oudheid was dit 'het geheel' van de kosmos. In het middeleeuwse, theologische wereldbeeld was dit 'het ene' beeld van de kerk 
(dus niet 'de Ene'). In onze tijd wordt al het zijnde teruggebracht tot een voor de mens in principe voorstelbaar 'al'.

Een tweede punt van kritiek heeft betrekking op de doodlopende weg die met name de idealistische filosofie opgegaan is door het menselijk denken en weten als identiek met het zijn te beschouwen. Het $z i j n$ is dan teruggebracht tot het voor de mens voorstelbare en kenbare. Rosenzweig zag dit als een reduktie. Alles wordt namelijk dan begrepen vanuit het denkende ik en zelfs gezien als vanuit het menselijk bewustzijn voortgebracht. "Diese Zurückfuhrung oder 'Begrundung' der Welt- und Gotteserfahrungen auf das Ich, das diese Erfahrungen macht, ist dem wissenschaftlichen Denken noch heut so selbstverständlich, das jemand, der an dieses Dogma nicht glaubt, sondern seine Welterfahrungen lieber auf - die welt und seine Gotteserfahrungen lieber auf - Gott zuruickfuhrt, einfach nicht ernst genommen wird" " schreef hij in het artikel "Das neue Denken' (Rosenzweig 1937,378). Uitgangspunt van Rosenzweig is dat het denken niet het zijn kan bepalen.

Rosenzweig neemt het zijn of de werkelijkheid, zoals hij veronderstelt dat deze los van het denken - "objektief" - bestaat, tot uitgangspunt. "Wir suchen nach Immerwahrendem, das nicht erst des Denkens bedarf um zu sein" (Rosenzwe1g $\left.1921,1976^{4}, 22\right)$. Hij veronderstelt het bestaan van een 'vóóronderstelde' (vlg.Loen $1973,10-21$ ), voordat dit door het denken 'subjektief' - bevestigd en tot begrip gebracht wordt. Bovendien aksepteert hij dit vooronderstelde als een voor de mens niet denkbare eigenheid en andersheid.

Doordat de werkelijkheid meer en anders is dan het denken kan bevatten en zij een eigen bestaan heeft, onathankelijk van het denken, kan er ook niet van één al sprake zijn. In het eerste deel beschrijft Rosenzweig dat er van drie, ten a anzien van elkar transcendente. 
dat wil zeggen niet tot elkaar te herleiden, 'elementen' sprake is. God is eerst. Hij is aanwezig en dit niet als menselijk voortbrengsel of eindpunt. Hij is er, mar niet in menselijke termen. Voorts is er de wereld. Ook zij is een eigen grootheid. Tenslotte is er de mens.

Rosenzweig bevestigt God en zijn bestaan als geheel en al goddelijk, de wereld en haar funktioneren als geheel en al wereldijjk, de mens en zijn zelf als geheel en al menselijk. Eerst als men dit aksepteert, valt er werke$1 \mathrm{ijk}$ iets te zeggen met betrekking tot God, de wereld en de mens; niet over hun wezen -. dat is niet kenbaar -, maar over hun werkelijkheid. Dit latste vat Rosenzweig zo letterlijk mogelijk op, namelijk als 'werk'-elijkheid. Het werken van God wordt gekenmerkt door een voor de mens niet te vatten oneindige macht en vrijheid van handelen. Het werken van de wereld komt tot uiting in de groei en ontwikkeling ervan. Kenmerkend voor de mens is, dat deze zich als 'bijzonder' ervaart en dat zijn bestaan vergankelijk is. Het specifiek menselijke leven komt tot uiting in de op handelen gerichte vrijheid van wil.

God, de wereld en de mens zijn de 'elementen' van onze werkelijkheid. Als zodanig plaatst Rosenzweig hen in het teken van een gelijkzijdige driehoek met de punt naar boven:

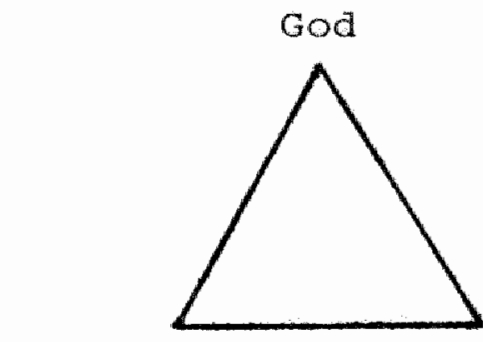

wereld

mens

Antropologisch is relevant dat de geboortedag van de mens wel de geboorte van zijn persoonlijkheid is. Het individu gaat dan deelnemen 
aan het leven van de menselijke soort. Mar dit is nog niet de geboorte van, wat Rosenzweig noemt, 'het zelf'. Deze ervaring van het eigen zelfbewustzijn, die de mens op een bepalde dag in zijn leven overvalt, is, zo zegt Rosenzweig, overigens een "tragische' ervaring. Deze konfrontatie mag aanvankelijk tot uiting komen in de gestalte van de naar schoonheid en volmakktheid leidende Griekse godheid Eros, uiteindelijk biedt dit geen perspektief en is er toch het lot van de door de godheid Thanatos gesymboliseerde dood. De mens lijkt niet aan zichzelf te kunnen ontsnappen. De op zichzelf staande mens is niet de werkelijke mens.

In het eerste deel van "der Stern' laat Rosenzweig het hierbij. De doorbraak voor de mens, en ook voor de beide andere, in dit deel nog in zichzelf gesloten voorgestelde, elementen de hier nog zwijgende God, de nog stomme wereld en de nog tragische mens - werkt Rosenzweig in het tweede deel uit. Het perspektief voor het leven komt in het derde deel.

$2 \cdot 3 \cdot 3$

Deel II: "Die Bahn oder die

allzeiterneuerte Welt".

Het tweede deel zet hiermee in, dat God, de wereld en de mens niet als elementen in geisoleerde posities voorkomen, mar dat $\mathrm{zij}$, zo zegt Reinhold Mayer in zijn boek over Franz Rosenzweig, ervaren worden als "das Geschehen einer Bezlehung zwischen den Elementen, das nicht aus dem wesen der Elemente rational ableitbar, also nicht im idealistischen Sinne denkend $z u$ erzeugen, sondern nur als erfahrenes Exeignis vom Sprachdenken durch Nacherzahlen darstellbar ist" (Mayer 1973,61). Wat wij ervaren is de beweging van het op elkaar betrokken $z i j n$ van de werkende c.q. handelende elementen.

In dit deel interpreteert Rosenzweig deze be- 
weging van "Aussichherausgehen, Zueinandergehören und zueinanderkommen der drei 'tatsächlichen" Elemente des $4^{A 11}$. Gott Welt Mensch" (Rosenzweig $1921,1976^{4}, 127$ ) als het openbaringsgebeuren (in ruime $z i n$ ) van schepping- openbaring (in strikte $z i n$ ) - verlossing. Het gebeuren van de openbaring doorbreekt de mogelijke willekeur en toevalligheid van de schepping en daarmee ook het 'tragische' van het mens zijn. In filosofische taal grijpt Rosenzweig in dit deel terug op de basiservaringen en -inzichten van de oude woorden van de joodse traditie.

De levensbeweging die de mens ervaart, vertolkt Rosenzweig als een beweging van nietwillekeurige en niet-toevallige gebeurtenissen. Grondslag en middelpunt van deze beweging is het openbaringsgebeuren van het woord van God aan de mensen. Dit gebeuren benoemden Rosenstock en Rosenzweig als oriëntatie voor het leven en daarmee voor het 'nieuwe denken' (ook 'Sprachdenken' genoemd).

Dit openbaringsgebeuren beschouwt Rosenzweig als "der verwirklichende Augenblick" in ons leven. Het is het moment (der Augen-blickl) dat het leven werkelijk léven geeft. Het is iets dat voortdurend weer plaats vindt. Het is dus geen historische, afgesloten gebeurtenis, maar levende historie die de wereld kontinu vernieuwt. Rosenzweig spreekt van een "wonder'. En hier ligt ook de brug naar de theologie, zegt hij in de inleiding tot ait deel. Hij noemt de theologie de verzorgster van het kind van 'vadertje geloof'. Het geloof heeft zijn liefste kind 'het wonder' zeer verwaarloosd, zo gaat Rosenzweig van start. "Aber kommt zeit, kommt Rat. Der Alte kann nicht ewig leben" (Rosenzweig 1921,1976,103). De theologen hebben het wonder van de openbaring onvoldoende serieus genomen en zij zijn op zijsporen terecht gekomen. Als motto boven dit deel plaatst Rosenzweig niet voor niets: "in theologos!", tegen de theologen! 
De openbaring in strikte zin, dat wil zeggen het woord dat de mensen bereikt, is niet het eerste openbaringsgebeuren, zo begint Rosenzweig het eerste hoofdstuk van dit tweede deel, dat de titel heeft "Schöpfung oder der immerwăhrende Grund der Dinge". "Gott sprach" " zo zegt hij, "Das ist das zweite". Het eerste, "der Anfang ist: Gott schuf". We horen hoe hier de woorden van het eerste boek van de Torah, het boek 'Beresjiet' (= om te beginnen) meeklinken (vlg.Gen.1:1). Het tweede, het spreken "ist schon die Erfillung, die laute, des $4^{\text {schweigenden Anfangs" (Rosenzweig } 1921,}$ $\left.1976^{4}, 124\right)$.

De betrekking tussen God en de wereld is de eerste betrekking. Het is de daad van de schepping die in deze betrekking tot uiting komt. Rosenzweig noemt dit gebeuren van de schepping: "der immerwährende Grund der Dinge" (id. 124). De betrekking tussen God en mens is de tweede verhouding die aan de orde is. Deze meest centrale betrekking, de openbaring, veronderstelt de eerste betrekking, die van de schepping. Maar eerst door de tweede wordt de eerste als schepping herkenbaar.

Hoewell het scheppen van God het $z$ wijgende begin is en God hier in alle opzichten nog verborgen is, terwijl de mens van de betekenis van $z i j n$ bestaan nog geen weet kan hebben (dit kan eerst in het horen van $\mathrm{zijn}$ Woord), moet men dit scheppen niet zo opvatten dat "in der gobttichen Schbpfung am weltmorgen die welt ein 'fertig' Geschaffenes geworden ist". De wereld is "vorerst noch weiter nichts als Geschópf" (id.,133). De dingmatig aan ons verschijnende wereld is schepping en dit kreatuur zijn van de wereld is een kontinue realiteit. Het is niet lets dat uitsluitend in het verleden gebeurd is. Evenzeer heeft het met het heden te maken en ook in de toekomst blijet relevant dat de wereld schepping is.

Doordat de wereld schepping is, is zij werkelijkheid en gebeurt alles werkelijk. Rosenzweig: "Die Welt ist kein schatten, kein 
Traum, kein Gemälde; ihr sein ist Dasein, wirkliches Dasein - geschaffene Schöpfung. Die welt is ganz gegenständich, alles Tun in ihr. alles 'Machen' ist, da es in ihr ist, Geschehen" (id.,147).

In het geschapene openbaart God zich in daden. Rosenzweig noemt dit: "die Tatsächlichkeit Gottes" (id.,179). De eerste uiting van God, die van het scheppen, verlangt nog "grade um ihres offenbarungscharakters willen, das Hervorbrechen einer 'zweiten' Offenbarung, einer Offenbarung, die nichts weiter ist als offenbarung, einer offenbarung im engeren, nein im engsten Sinn" (id.,179). De eerste openbaring is het scheppend handelen, de tweede is het spreken van God. Ik wees er hiervoor al op dat de schepping niet als zodanig te verstaan is zonder het gebeuren van de tweede openbaring. Rosenzweig: "Es ist nicht möglich, die Schöpfung, deswegen zu glauben, weil sie eine zureichende Erklärung des Welträtsels bietet. Wer von der stimme der offenbarung noch nicht erreicht ist, hat kein Recht, den Gedanken der Schöpfung, als wäre er eine wissenschaftliche Hypothese, anzunehmen" (id.,149;vlg.id.,154).

Deze tweede openbaring, als gesproken woord openbaring in strikte zin, moet (evenals de eerste) verstaan worden als een doorbraak van buiten. In filosofische termen zou men kunnen zeggen dat het niet om een immanente, maar om een transcendente beweging gaat. De openbaring is geen getuigenis of verwoording van een opvatting of idee, maar $z i j$ is een met betrekking tot de mens werkelijke gebeurtenis. Zij is geen verklaring, maar 'woord' dat de mensen a anspreekt. Het is de ander die door zijn woord de, in zichzelf besloten, zelf-ervaring openbreekt. Deze ervaring die de mens plotseling kan treffen - als een ogen-blik - is niet opgesloten in het verleden, maar, zo zegt Rosenzweig. "die offenbarung ist der seele das Erlebnis einer Gegenwart, die auf dem Dasein der Vergangenheit zwar ruht, doch nicht darin 
haust, sondern im Lichte des göttlichen Antlitzes wande1t" (id.,174). Zij is een ogenblik dat telkens weer kan voorvallen als verwerkelijking van de betrekking tussen God en mens. Rosenzweig noemt dit de "Offenbarung oder die allzeiterneuerte Geburt der Seele" (id.,174). Het nog door de dood geprogrammeerde "verschlossene selbst', zoals we dat hiervoor hebben leren kennen, verkeert nu in de "Lebendigkeit der seele".

Met de opmerking dat de openbaring als louter levende tegenwoordigheid ervaren wordt, terwijl deze tegelijk op het verleden rust, verwijst Rosenzweig naar de voortdurend aktuele betekenis van de oude woorden van de Torah (zie ook hoofdstuk 3). De Torah is als zodanig openbaring. Tegelijk vinden we hierin het Exodusverhaal als van centrale betekenis. Het bevat een passage waar Mozes naar Gods naam vraagt (Ex:3:13-14). Rosenzweig gat hiervan uit als hij tot de kern van het openbaringsgebeuren doordringt. "Grund der offenbarung. Mittelpunkt und Anfang in eins; ist die offenbarung des gottlichen Namens" (Rosenzweig $\left.1921,1976^{4}, 209\right)$. Later, in de tezamen met Martin Buber gepresenteerde 'Verdeutschung der Schrift', horen wij in alle helderheid de naam als "ICH BIN DA" verwoord, terwijl Buber en Rosenzweig het antwoord dat God aan Mozes gaf op diens vraag "Was ists um deinen Namen?" al even pregnant en aktueel vertalen als "Ich werde dasein, als der loh dasein werde" (Namen $3,13-14)$.

Evenmin als de wereld een schaduw, een drooin of efn schilaerif is (vlg.Rosenzweig 1921 , $1976,147)$, evenmin is de naam van iemana geluid en rook. "Name ist nicht, wie der unglaube immer wieder in stolz-verstockter Leere wahrhaben möchte, Schall und Rauch, sondern wort und Fetuer" (id.,209). Als men de naam van de ander (de Ander) kent en uitspreekt, wil dit ook zeggen dat men geloof hecht aan de ander en dat men de ander in zijn aanwezig zijn bevestigt (v1g.id.,209). 
De mens die zich open naar de levenswerkelijkheid opstelt en bereid is naar de woorden van de Torah te luisteren, leert het woord van de Torah niet alleen als levend woord, als gesproken woord, kennen, maar hij ervaart ook, dat hij persoonlijk aangesproken wordt. Hij wordt bij zijn naam geroepen: "Mens, Adam, war ben je?" (zie id.,195-196). "Leben heisst angeredet werden", zegt Martin Buber, en hij vervolgt: "Wir brauchen nur uns zu stellen. nur zu vernehmen" (Buber 1972,153). We moeten, zegt Rosenzweig, uit de stomme beslotenheid van onze eigengereidheid willen stappen (Rosenzweig $1921,1976^{4}, 187-188$ ).

De mens wordt niet alleen persoonlijk aangesproken, met andere woorden, hij is niet alleen 'openbaringsontvanger", zegt De Miranda, die aansluit bij het denken van Buber en Rosenzweig, "mar de werkelijkheid die hem aanspreekt, oproept en onder verplichting stelt, blijkt zelf voor de mens aanspreekbaar te zijn als een nabije persoon" (De Miranda 1983,126). De openbaringsbetrekking geeft de mens de mogelijkheid tot ommekeer en daarmee tot antwoorden. Het begrensde gesprek van het in zichzelf opgesloten ik kan door de mens doorbroken worden. Het kan tot dialoog worden, namelijk "indem das Ich das Du als etwas ausser sich anerkannt" (Rosenzweig 1921,1976 ,195). De mens weet nu niet alleen dat er 'leven' voor hem is - leven vanuit een transcendente beweging en daardoor sterker dan het immanente van de dood - maar hij beseft ook, dat dit leven hem tot verantwoordelijkheid oproept. De mens is op zijn beurt weer in staat het leven te bevestigen. "Wie Er dich liebt, so liebe Du", stelt Rosenzweig kort en bondig (id., 228). Hierover spreekt Rosenzweig in het derde boek van dit tweede deel. Naast de schepping als openbaring en de openbaring (in enge $z i n$ ) is er de verlossing, en dit is eveneens een vorm van openbaring. Het is de vorm waarin het de ander (de Ander) - ik gebruik hier de ter- 
minologie van Levinas - mogelijk gemaakt wordt te leven en present te zijn. Het is in deze zin dat de mens in de joodse traditie 'Gods partner' genoemd wordt.

Het teken warin Rosenzwelg het tweede deel van 'der stern der Erlösung' plaatst is een gelijkzijdige driehoek met de punt naar beneden:

\section{Schöpfung offenbarung}

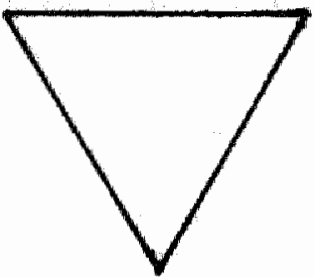

Erlösung

Met dit alles heeft Rosenzweig de kern verwoord van wat er menselijkerwijze vooralsnog te zeggen valt over ons bestaan. Toch ontbreekt in het schema van Rosenzweig naast "die Vorwelt' en 'die Welt' nog 'die Ueberwelt'. Naast verleden en heden ontbreekt nog de toekomst. Naast de monoloog en de dialoog ontbreekt nog de samenspraak. Naast "die Tatsächlichkeit' en 'die Wirklichkeit' ontbreekt nog 'die Wahrheit'. Naast 'die Elemente' en 'der Bahn' ontbreekt nog 'die Gestalt'. ewige Ueberwelt".

Het leven in de gemeenschap, "die ewige Ueberwelt", is het thema van het derde deel van 'Der Stern der Erlósung'. Wat de mens betreft ging het in het eerste deel om de mens die de gersoleerdheld van zijn bestaan niet te boven kan komen. Het is de mens die beseft, dat zijn zelf een uiteindelijk 'tragisch' zelf is. In het tweede deel hebben we gezien hoe deze mens 
tot de "von Gott wachgerufene seele" (Rosenzweig $\left.1921,1976^{4}, 239\right)$ geworden is. We hebben de dialogische grondslag van het mens zijn leren kennen. In dit derde deel bespreekt Rosenzweig de sociale strukturen warin de mens hier en nu met anderen samenleeft en waarin hij tegelijk anticipeert op de toekomst. Het zal na het tweede deel duidelijk zijn, dat dit leven in de gemeenschap geordend is rond het woord van de openbaring, rond het woord van de Torah als oriëntatie (vlg.ook par.2.3.1).

Eerst echter gaat Rosenzweig nog door op het thema van de verlossing. Het is alsof hij nog geen afscheid kan nemen van het hem zo geliefde tweede deel.

Wil het handelen van de mens werkelijk verlossend zijn voor de medemens en voor de wereld, dan houdt dit in, dat het aan de juiste tijd, aan het juiste moment gebonden is. Handelen is historisch handelen en dit behoort juist en rechtvaardig te zijn. De wereld en de mensen hebben hun tijd nodig. Deze juiste tijd ("die rechte zeit") is ook de tijd van God. Het leven mag geen geweld aangedaan worden. De tijd mag noch vertraagd noch versneld worden. De toekomst mag niet afgedwongen worden. Het motto boven dit deel heeft hierop betrekking: "in tyrannos!", tegen de tyrannen!

De toekomst, het rijk, waarvan de mensen dromen, dat $z i j$ menen te bezitten en/of in gedachten hebben en waarvoor zij 'bidden', is niet af te dwingen. Rosenzweig onderkent twee vormen van dwang. Men kan de levensbeweging en de veranderingen die zich voordoen proberen tegen te houden of men kan proberen de geschiedenis te versnellen. Hij noemt iemand die de tijd wil vertragen een 'zondaar" en iemand die de tijd wil versmellen betitelt hij als een "dweper". De zondaar is eenzijdig op zichzelf gericht en in zijn gebed is hij in feite met zichzelf bezig. De dweper passeert echter eveneens zijn naaste, en ait in letterlijke zin, omdat hij bezig is met een door hem ei- 
genmachtig te realiseren doel van het leven. Het doen en laten van de dweper en van de zondaar is niet echt werkelijkheidsbetrokken. Het houdt niet werkelijk rekening met de ander en het heeft geen weet van een handelen "op het juiste moment'. De verantwoordelijkheid voor en de opdracht tot verlossen wordt dan verkeerd opgevat. Er wordt niet voldaan aan het alalogische en persoonlijke karakter van de verlosing. Dit doen, van het juiste en het goede, beschrijft Rosenzweig in alle scherpte als: "Denn was ist die Erlösung sonst als dies, dass das Ich zum Er Du sagen lernt?" (Rosenzweig $1921,1976,305$ ).

Dit persoonlijke karakter, dat voor het werkelijk verlossend handelen kenmerkend is, heeft ook een transcendente dimensie. Ook de medemens is "von Gott wachgerufene seele", is schepsel en openbaringsontvanger, "er ist wie Du, wie dein Du, ein Du wie Du, ein ICh, Seele" (id.,267). Dit betekent, dat van de mens verlangd mag worden, het transcendente levenselement mee te laten spreken, in de woorden van Rosenzweig: "die Ewigkeit zum Nächsten, zum Heute zu machen (...). Sie (die Ewigkeit) muss stets "heute' schon kommen können; nur dadurch ist Ewigkeit" (id.,321-322).

Rosenzweig werkt dan in dit deel uit hoe in de ordening van het leven het bovenstaande gerealiseerd kan worden. Hij refereert aan het scheppingsverhaal en aan de instelling en de betekenis van de sabbat (Gen.2:2-3;Ex.16:229).

De week en speciaal de sabbat is geen strikt menselijke instelling. zij zijn van een hogere orde (zie ook Jon Weizsäcker 1966,49-60; Heschel $1951,1977^{3}$ en verder hoofdstuk 5). Dit leidt ertoe dat de week niet alleen het werk van de 'kultuur' reguleert, mar dat ook 'kultische' zaken een rol spelen.

De ordening van de tija ordent niet alleen het leven van de enkeling, maar tegelijk dat van de mensen met elkaar. De tijd gaat niet alleen 
de enkeling aan, maar iedereen. "Tag, Woche, Jahx gehören allen gemeinsam" (Rosenzweig $1921,1976,325)$. De ordening van het leven. die een gemeenschappelijke ordening is en tegelijk, op de hiervoor gestelde basis, een gemeenschap stichtende ordening, noemt Rosenzweig dan ook de anticipatie op de toekomst. Deze gemeenschap en toekomst stichtende anticipatie gebeurt, naar de opvatting van Rosenzweig, op twee wijzen: in de "Gemeinde des ewigen Lebens" - in de synagoge, in de joodse traditie - en in de "Gemeinde des ewigen Wegs" - in de kerk, in het christendom. Rosenzweig wijdt aan beiden in dit derde deel een apart boek. Hij doet dit aan de hand van de jaarordening van de tijd met hierin voor jodendom en christendom eigen feestalgen en een eigen strukturering van het leven en samenleven. Ik ga hier niet verder op in. Op de joodse traditie ga ik in het volgende hoofdstuk nader in, niet op basis van de ordening van de tijd, maar op basis van het specifieke leerkarakter van deze traditie. Nu volgt alleen een korte karakteristiek van de beide boeken.

In het derde boek van dit derde deel brengt Rosenzweig het probleem van de waarheid ter sprake. Het westerse denken heeft altijd de watheid voorop willen stellen en is op zoek naar de warheid. $\mathrm{zij}$ zou dus nu kunnen zeggen: de warheid is God. Maar dit is nu juist het omgekeerde van wat werkelijk war is. De warheid is niet God, mar omgekeerd: "Gott ist die Wahrheit" (Rosenzweig 1921,1976"423). Wat wij ervaren is dat God op ons betrokken is. Wij ervaren dat God leeft en ons lief heeft, niet dat hij 'de waarheid' of 'de Liefde' is. Dit zijn abstrakte begrippen. In deze zin sluit Rosenzweig aan bij het joodse weten. dat altijd meer warde gehecht heeft aan het leven en het leven met elkaar - aan verlossing - dan aan 'de waarheid' (zie Midrash Rabbah, Gen.R.VIII,5). Door te leven - in een direkte persoonlijke betrokkenheid op de ander (de An- 
der) - heeft de mens wel deel an de warheid. Deel hebben aan de warheid is dan leven in de werkelijkheid, zoals deze 'in warheid' werkzaam is.

Het teken van dit laatste deel is het teken dat Rosenzweig op de eerste druk van zijn boek zette. De twee driehoeken schuiven in elkaar tot 'der Stern der Erlósung' en hiermee tot 'der Stern oder die ewige Wahrheit', zoals de titel van het laatste boek luidt.

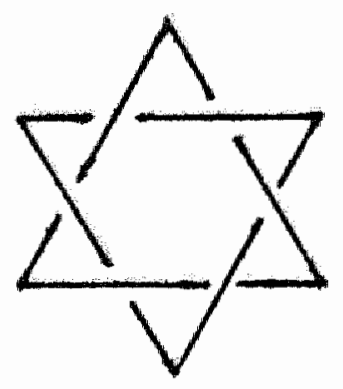

Rosenzweig opende 'der stern' met de woorden "Vom Tode, von der Furcht des Todes". Zij zijn het die veelal tot aangrijpingspunt van ons kennen gemomen worden. Maar het denken blijkt deze warheid niet haar angel te kunnen ontnemen. Dat kan alleen de verlossing, warbij de mens Gods partner is. Het perspektief dat Rosenzweig biedt is, dat niet de dood het eerste en het laatste woord heeft, maar het leven. Na een verwijzing gegeven te hebben naar de profeet Micha $(6: 8)$ eindigt Rosenzweig zijn boek als volgt: "Einfaltig wandein mit deinem Gott - die Worte stehen Uber dem Tor, dem Tor, das aus dem geheimnisvol1-wunderbaren Leuchten des göttlichen Heiligtums, darin kein Mensch leben bleiben kann, herausfuhrt. Wohinaus aber öffnen sich die Flugel des Tors? Du welsst es nicht? Ins Leben" (id.,472). Ik wijs hierbij ook op de tekst die ik in het voorwoord noende en warin onder andere staat: "Maak mij bekend wat de poort is die open staat naar het leven". Het antwoord is: "de vreze des Heren" (Van Uden 1981,41; Midrash Rabbah, Lev.R.XXX, 2). Hiermee wordt een verwijzing gegeven naar de 
Torah (zie hoofdstuk 3 ).

2.4 .

Rosenzweigs verdere leven en werk, met name het leerhuiswerk.

Nadat Rosenzweig in 1919 'Der Stern der Erlösung' voltooid had, zocht hij naar een mogelijkheid om zijn intussen verkregen inzichten omtrent leven en, wat hem betreft, ook zijn eigen wijze van leven, verder gestalte te kunnen geven. Ofschoon deskundige in de westerse filosofie en kultuurgeschiedenis, weigerde hij een verdere karrière op dit gebied. Een aanbod van zijn promotor, Friedrich Meinecke, sloeg hij af (zie Rosenzweig 1979,Bd.2,679). In een beward gebleven konsept voor een brief aan Martin Buber schreef hij: "Nur im Leben, nicht mehr im Schreiben sehe ich noch zukunft vor mir" (Rosenzweig 1935,371;id.,1979, Bd.2,645). Dat hij desondanks nog diverse artikelen zou schrijven, doet aan deze levensinstelling niets af (Rosenzweig 1920,1924,1983; id.,1935; id. .1937;id.,1953,1964;id.,1979).

Reinhold Mayer schrijft in zijn boek over Franz Rozenzweig: "Gemäss dem Schluss des 'stern der Erlösung', der ins Leben zurückfihrt, strebte Rosenzweig nach der Verwirklichung des Erdachten im Leben durch Bewăhrung der wahrheit: an die stelle des romantischen Schwelgens in den vielen Möglichkeiten sollte der konkrete Lebensvollzug mit seiner einheitlichen Forderung treten. Wie einst die Theorie der Praxis vorangehen musste, so bekam jetzt die Praxis Schwergewicht vor der Theorie" (Mayer $1973,68-69$ ).

Wat Rosenzweig voor ogen stond was joods te leven en joods te leren. Maar evenmin als hij deskundige wilde zijn op het gebied van de westerse filosofie en kultuurgeschiedenis, wilde hij specialist zijn op het terrein van het jodendom. "Ich bin so wenig spezialist fir Judaica wie Max Weber", schreef hij in 1921 
aan Hans Ehrenberg, en tussen haakjes voegde hij eraan toe: "das Jüdische ist meine Methode, nicht mein Gegenstand" (Rosenzweig 1935, 407 ; d. .1979 Bd.2,720).

Intussen had "Der Stern der Erlösung' Rosenzweig wel het image van specialist gegeven. Voordat het boek in 1921 officiëel verscheen, was de roem erom het al vooruitgesneld. Rosenzweig werd uitgenodigd bij een initiatiefkomitee voor 'joodse volksvoordrachten' in Frankfurt am Main. De eerste voordrachten waren al in het seizoen 1919-1920 gehouden. Rosenzweig werd gevraagd de leider van deze 'volksvoordrachten' te worden. Met ingang van augustus $1920 \mathrm{kreeg} h i j$ de benoeming tot leider van wat hij korte tijd later tot 'Das Freie Jüdische Lehrhaus' zou gaan maken.

De Frankfurter groep stond op het moment dat zij Rosenzweig aantrok, nog geen leerhuis voor ogen in de zin van het oude rabbijnse leerhuis 'Bet ha-Midrasj', eenvoudigweg omdat men dit onvoldoende kende. Men dacht meer aan een soort volksontwikkelingswerk, in ait geval vanuit de joods traditie. 'Kulturele verheffing van het joodse volk, was wel het laatste dat Rosenzweig bedoelde. Evenmin stond hem een onderwijsinstituut in meer moderne zin, zij het een dat dat jodendom tot objekt van studie heeft, voor ogen. Een van de medewerkers van het eerste uur van het door Rosenzweig zo genoende "Vrije Joodse Leerhuis', de arts Richard Koch, karakteriseerde het leerhuis als volgt: "Es ist keine schule, kein Institut, kejn Seminar, keine Anstalt. Es hat nur einen im Kern, aber nicht in Abgrenzung und Anordnung, festen Lehrstoff. Es bildet zu nichts vor, es tritt auch nicht an stelle einer andersartigen Einrichtung. Es hat mit Volksbildung im ublichen sinne des wortes nichts zu tun... Am ehesten ist es noch dem traditione1len "Iehrhaus" verwandt. Es dient, wie dieses der pflege eigenen, ererbten Besitzes... Das Lehrhaus soll uns lehren, warum und wozu wir 
es sind... In diesem sinne ist es eine Bildungsanstalt" (bij Veit.1973,82-84;zie ook Rosenzweig 1979, Bd.2,689).

Aan de joodse deelnemers van het leerhuis werd niet gevraagd om 'als jood' te komen. Ook als zij voor zichzelf niet meer de aansluiting met de joodse traditie uitdrukkelijk beleefden mochten zij binnenkomen en horen. Ook niet-joden waren welkom, alhoewel het om het bezig zijn met joods weten, om joods leren, ging. Dit laatste kwam in de nam 'het vrije Joodse Leerhuis" tot uiting. Het leerhuis was zonder examen of diploma toegankelijk. Het woord vrij hield ook in dat het leerhuis een onafhankelijke positie innam ten aanzien van de gevestigde belangen en posities van orthodoxie, liberalisme en ook ten aanzien van die van het zionisme en van de overheid (zie Rosenzweig $1935,450 ; \mathrm{id} ., \mathrm{Bd} .2,852)$ ).

Het leerhuis paste niet de (destijds) gebruikelijke akademische methode toe, warin de stof in de vorm van eenrichtingsverkeer en als het ware op een presenteerblad aan de leerlingen voorgeschoteld werd. Er was altijd diskussie mogelijk. Zonder het stellen van vragen en van betrokkenheid over en weer kan men niet van 'lernen' praten. De voordrachten werden voor nadere uitleg en onderling gesprek onderbroken. Het levende woord was van hogere orde dan op schrift gestelde voordrachten. Het leerhuis kende ook werkgroepen warin de geboden themata nader uitgewerkt en verwerkt werden. Bovendien werden sommige themata uitsluitend in werkgroepverband bestudeerd. Vanaf het seizoen 1925-1926 werden er geen voordrachten meer gehouden. Het leerhuis kende toen enkel leergroepen.

Zeker in die tijd was het geheel nieuw, dat de leraren op hun beurt ook toehoorden en luisteraar werden. Zo stond het Rosenzweig wel voor ogen: de docenten doen mee aan het gesprek: zij zijn de "Chorfuhrer des Chors der Fragenden" (Rosenzweig 1938,101). Rosenzweig stimu- 
leerde dat zij ook zelf als leerlingen aan leergroepen deelnamen. En de leerlingen konden op hun beurt leraar worden. Zo onder andere Erich Fromm en Nahum Glatzer. Rosenzweig vond het van wezenlijk belang dat het vermogen tot leren van degenen die zichzelf als leerlingen beschouwden, opgewekt werd (zie ook hoofdstuk 3 en Abram 1980). De leraren hoefden geen vakdeskundigen in judarca te zijn. Om het bedrijven van wetenschap omwille van de wetenschap ging het niet. Naast Rosenzweig werkten onder andere een biochemicus (Eduard Strauss), een arts (Richard Koch), een pedagoog (Ernst simon, later hoogleraar in Jeruzalem), een historicus, een kunstenaar en een politicus aan het leerhuis mee. Ook Martin Buber werkte mee, warover dadelijk meer. Het waren allen 'Heimkehrer' in de joodse levenstraditie. evenals Rosenzweig zelf. Dit gold ook voor twee studenten die het sekretariat voerden, Martin Goldner en Rudolf Stahl. Rabbijn Nehemila Nobel was een uitzondering.

Zijn eigen taak als leerhuisbegeleider zag Rosenzweig vooral tot uiting komen in de kontinuiteit van zijn aanwezigheid en in het leggen van verbindingen. Hij achtte dit van hoger orde dan door een bepaalde wijze van optreden zijn leiderschap bevestigd te zien. Hij wilde op geen enkele hiërarchische of dogmatische wijze de leervrijheid aantasten. "Leervrijheid' beschouwde hij niet als een pedagogischdogmatisch begrip. mar als "die Abhängigkeit des Lehrers von denen, die wiederum von ihm abhängig sind. Auf dieser wechselheit, die das Wesen des Erwachsenenunterrichts ist, beruht die einzige Lehrereiheit, die keine Phrase und kein Dogma ist" (Rosenzweig 1935,459;id.1979, $\mathrm{Bd} \cdot 2,863$ ): Zichzelf vond Rosenzweig als leraar niet zo'n sukses. Zijn toehoorders begrepen hem slecht (Rosenzweig 1935,$455 ;$ id.1979, Bd.2. 857; zie ook 1d.,Bd.2,709-710 en Von weizsäcker $1949,1951,12)$.

De themata die in het leerhuis cyclisch aan de orde kwamen, boden een grote variatie. $\mathrm{zij}$ be- 
troffen - om een indruk te geven - onder meer: de Torah, de Profeten, Tenach, Halacha en Aggada, aspekten van het oude, mar ook van het moderne jodendom (zoals de situatie van de 'Heimkehrer' die Rosenzweig eens het zaad van de toekomst noemde), joodse geschiedenis, joods denken en joodse kunst, het jodendom en de wereldgodsdiensten, enz. Het aantal ingeschreven deelnemers bereikte in januari 1923 een hoogtepunt: 1100 .

Naast Franz Rosenzweig werd Martin Buber de belangrijkste steunpilaar van het vrije joodse leerhuis (vlg. Rosenzweig 1925,462 ; id. .1979, Bd. $2,866)$. Rosenzweig was in 1914 in Berlijn met de wat oudere Buber gaan kennismaken. In 1916 was Buber naar Heppenheim aan de Bergstrasse verhuisd. Buber was docent en later hoogleraar in Frankfurt. Toen Rosenzweig in 1920 ook naar Frankfurt kwam, nam hij spoedig daarna weer kontakt op met Buber. In de herfst van 1921 verzocht hij diens medewerking voor het leerhuis (zie Rosenzweig 1979, Bd.2,725). Dit werd het begin van een in intensiteit toenemende samenwerking, met als hoogtepunt - in de jaren 1925 tot aan Rosenzweigs dood in 1929 - de door hen beiden gezamenlijk ondernomen 'Verdeutschung der Schrift', de vertaling van de Hebreeuwse bijbel in het Duits.

De in 1878 in wenen geboren en in 1965 in Jeruzalem gestorven Martin Buber was evenals Rosenzweig uit een aan de Duits-europese kultuur geassimileerd joods milieu afkomstig. Buber werd aanvankelijk door het zionisme gegrepen. Hij koos echter alweer snel een andere weg. alhoewel het politiek-maatschappelijke leven hem tot het einde van zijn leven zou bezighouden (Sperna Weiland 1978,50-59). Via het chassidisme ontwikkelde Buber zich tot de 'dialogische ervaringsdenker' en gespreksfilosoof in welke hoedanigheid hij met name ook buiten het jodendom bekendheid heeft gekregen. De eerste bijdrage van Buber betrof het chassidisme (Rosenzweig 1979,Bd.2,730-731). Buber 
was echter reeds vanaf 1913 bezig met het thema dat begin 1923 zou leiden tot de publikatie van 'Ich und Du' (vIg.Waaijman 1976,33-47). Rosenzweig wist dat in 1921 nog niet, terwijl van zijn kant Buber niet op de hoogte was van Rosenzweigs 'nieuwe denken' dat in dezelfde richting ging (id.,98-125; Horwitz 1978,183239). In de vorm van een voorstudie werkte Buber zijn inzichten in 1922 in het leerhuis nader uit. Hij deed dit onder de titel. 'Religion als Gegenwart' (zie Horwitz 1978). Voor Buber was het de eerste keer dat hij niet alleen als spreker, maar ook als leraar in de zin van het 'Bet-ha-Midrasj' en als gesprekspartner ging optreden. In een brief aan Rudi Ha110 - die Rosenzweig kortstondig zou opvolgen als leerhuisleider - schreef Rosenzweig in december 1922: "Es war seine erste zyklische Vorlesung. Bisher hatte er immer nur rednerische Vorträge gehalten. Gerade die Eigenart des Lehrhauses reizte ihn, das zwischengefragtwerden, das nicht rein Vortragsmässige, das mehr Lehren als Reden" (Rosenzweig 1935, $462 ; 1 d ., B d .2,866)$. Een maand later schreef Rosenzweig aan Hallo: "Du sagst, Buber war gut. Diese Gute darf sich das Lehrhaus ein wenig auch zuschreiben. Er hat hier zum ersten Mal eine ihm gemässe Gelegenheit gefunden, wirklich zu lehren, nicht zu reden" (id.,473; id., Bd. 2,886).

De relatie met Buber verdiepte zich zó, dat Rosenzweig hem ook beleidsmatig bij de opbouw van het leerhuis betrok. En door onvoorziene omstandigheden kwam de bifdrage van Buber al spoedig op een nog breder vlak te liggen. Franz Rosenzweig begon in 1921 tekenen van een ernstige ziekte te vertonen. Viktor von weizsacker stelde de diagnose vast: amyotrofe lateraalsklerose, een over het algemeen binnen drie jaar tot de dood leidende spierziekte (Von Weizsäcker 1949,1951; zie ook Rosenzweig 1979. Bd.2,750). Al gauw was hij gedwongen zijn positie als leerhuisleider op te geven. De 
toenemende verlammingsverschijnselen makten hem het lopen, maar ook het spreken en schrijven steeds moeilijker en langzamerhand onmogeIijk. Zijn bezorgheid over de toekomst van het leerhuis deelde hij met Martin Buber. Maar op 19 augustus 1922 kon hij hem schrijven: "Es gibt seit einigen Tagen doch ein spater für das Lehrhaus" en parafraserend op een tekst uit Jeremia, voegde hij in het Hebreeuws er aan toe: "er is hoop voor mijn toekomst" (Jer.31:17). (Rosenzweig 1935,439;id.,1979, Bd. 2,809).

Rosenzweig had in de persoon van de nog jonge oriëntalist en archeoloog Rudolf Hallo een opvolger gevonden. In een brief droeg Rosenzweig begin december $1922 \mathrm{zijn}$ funktie over. Deze brief, warin hij uitvoerig de voorgeschiedenis en de situatie van het leerhuis op dat moment beschrijft, is beward gebleven (zie id. , 448-468; id. , Bd. $2,849-872$ ).

Tot grote teleurstelling van Rosenzweig en ondanks de steun die hij vanuit zijn ziekenkamer was blijven geven, lukte het Hallo niet zijn funktie als leerhuisleider waar te maken. Hallo begreep niet war het Rosenzweig eigenlijk om ging. Zo moest Rosenzweig onder andere in een brief van 4 februari 1922 an hem $z i c h$ verdedigen door te zeggen, dat hij en ook anderen hun jood $z i j n$ niet op de joodsheid van hun denken baseerden, maar dat het juist om het omgekeerde gaat (id.,476;id.,Bd.2,889). Na het zomersemester van 1923 hield Hallo ermee op. Een opvolger was niet direkt te vinden. Rosenzweig deed een beroep op de vaste lerarengroep om gezamenlijk de leiding te nemen. Drie van hen, onder wie Buber, zeiden toe het werk naast hun andere werkzaamheden te gaan doen. Zodoende kon het leerhuiswerk tot 1928 doorgaan. Toen begon het te verlopen. In 1930 werd incidenteel nog een voordracht gehouden. In 1933 nam Martin Buber het leerhuiswerk opnieuw op. Op 19 november van dat jaar heropende hij 'das Frankfurter Judische Lehrhaus' met een voordracht getiteld: 'Aufgaben Judischer 
Volkserziehung". Deze en diverse andere leerhuis-voordrachten zijn opgenomen in de in 1936 verschenen bunde1 'Die Stunde und die Erkenntnis' (Buber 1936). Ook buiten Frankfurt gaf Buber in die jaren alle andacht an het "permanent leren. (Abram 1980) om in die jaren nog te redden wat er te redden viel en om nog zoveel mogelijk aloude warden en menselijke waraigheid overeind te houden. Hij deed dit door het geven van kursussen, vooral aan joodse leraren en onderwijzers, en door de oprichting van een 'Mittelstelle flir judische Erwachsenenbllaung'. Tot 1938 kon hij nog werken. "Vom Ungeist jener Zeit verfolgt, verliess er Deutschland im Jahre 1938", staat op de aan de gevel van zijn vroegere woonhuis in Heppenheim bevestigde plakette. Hiermee kreeg het initiatief van Rosenzweig om het joodse leren weex het middelpunt van het joodse leven te maken en zo weer tot de kern van de joods identiteit en tot de betekenis hiervan voor het mens zijn door te dringen, een voorlopig einde.

Intussen was Rosenzweig desondanks erin geslaagd naast 'een nieuw denken'. 'een nieuw leren' tot stand te brengen - en daarmee 'een nieuw leven'. In 1917 had hij al een eerste aanzet gegeven met het opstel "Zeit ists..." (Rosenzweig 1937,56-78). Hierin merkte hij onder andere op, dat de joodse opvoeding verschraald was tot een soort godsdienstonderwijs voor joden en dat er geen aprake meer was van een het gehele leven doordringend joods leren. Het is dan ook de hoogste tija om het onderwijg te vernleuwen en weer nieuwe levendigheid in de gemeenschap te brengen.

De jood had met de emancipatie en het verlaten van de getto's buiten het jodendom een geeste$1 \mathrm{ijk}$ thuisland gevonden. Van het traditionele joodse leren, het 'lernen', kwam nlets meer terecht, lezen we in het bewaard gebleven ontwerp van de openingsrede voor het leerhuis, dat de titel draagt 'Neues Lernen' (1920). 
(Rosenzweig 1937,94-99). De jood in de twintigste eeuw keerde niet meer naar zijn eigen wijze van mens zijn terug. "Die alte Form sich das Leben in Zusammenhang met dem Buch zu halten. das Lernen, versagt" (id.,96). Even daarvoor merkte hij op: "Das Buch, um das wir uns einst sammelten - es steht einsam inmitten dieser Welt" (id.,96). Het moderne leren was niet meer aan de woorden van de Torah en aan de traditionele rabbijnse uitleg gebonden. En vaders leerden niet meer aan hun kinderen. De levensnoodzaak van leer en 'lernen', werd niet meer gezien en ervaren, zo moest Rosenzweig konstateren.

Door het 'lernen' niet meer te (be)leven, was het joodse volk in de ogen van Rosenzweig in de periferie van het bestaan terecht gekomen. Het waren bovendien niet de minsten, die het joods erfgoed achter zich lieten. Zo had voor hen het streven tot de ontwikkelden van de Europese kultuur te behoren de plaats ingenomen van het traditionele 'lernen" en van joods leven. Je kunt dit dan wel emancipatie van het jodendom noemen, zo ontwikkelde Rosenzweig zijn gedachten in het artikel "Bildung und kein Ende", maar eigenlijk begint de emancipatie voor de joden nu pas, namelijk in de strijd om het recht op een eigen joods bestaan (id.,86).

Deze ommekeer zag Rosenzweig tot stand komen in 'een nieuw leren'. Hiermee bedoelde hij een leren dat aan de situatie aangepast is. De situatie was nu eenmal nieuw, anders dan de vroegere situatie. Aan de realiteit valt niet voorbij te gaan. De veranderde situatie vormde voor hem juist het vertrekpunt voor een nieuw leren. Zo wilde hij weer de verbinding met de joodse traditie leggen (zie id.,96-97). Het leerhuis vormde voor Rosenzweig het middel- en keerpunt voor een hernieuwd joods leven. Voor onze tijd heeft hij hiermee weer de verbinding gelegd met het aloude 'lernen' en met het "bet ha-Midrasj', het leerhuis (zie ook op 't Root $1983,32-44$ ). 
De samenwerking met Martin Buber leverde nog een kleinood voor de mensheid op, namelijk 'die Verdeutschung der Schrift'. Buber en Rosenzweig slaagden met deze vertaling van de Hebreeuwse bijbel in het Duits erin het geheel eigen karakter van het Hebreeuws taaleigen in het Dults te laten doorklinken (zie Rosenzweig 1927,$154 ; \mathrm{id} ., 1983,2 ; \mathrm{id} ., 1937,134-136 ; \mathrm{id} ., 180-$ 181 ; Buber 1979,41$)$. Het is hier niet de plaats om uitvoerig op het vertaalwerk van Buber en Rosenzweig en de betekenis in te gaan.

Ik laat nu enkele regels volgen uit de 'gesproken woord' vertaling van Buber/Rosenzweig, regels die niet zozeer vragen om in stilte gelezen, maar eerder om hardop gelezen te worden en om voorgelezen en gehoord te worden.

"ER sprach zu Abram:

Geh du aus deinem Land, aus deiner verwandtschaft, aus dem Haus deines Vaters

in das Land, das ich dich sehn lassen werde. Ich will dich $\mathrm{zu}$ einem grossen stamme machen und will dich segnen

und will deinen Namen grosswachsen lassen.

Werde ein segen.

Segnen will ich, die dich segnen, die dich lastern, verfluche ich.

Mit dir werden sich segnen alle sippen des Bodens".

Abram hoorde de woorden en hij luisterde, dat wil zeggen hij handelde ernaar: "Abram ging, wie ER zu ihm geredet hatte, und Lot ging mit ihm" (Im Anfang 12,1-4;Gen .12:1-4).

Toen Rosenzweig in 1929 overleed waren hij en Martin Buber gevorderd tot het boek Jeschajahu. "Der letzte Satz, den er am Tag vor seinem Tod $z u$ "diktieren" begann, dessen Beendigung er aber auf den nächsten Tag verschob, galt der Deutung des 53. Jesaja-Kapitels, an dem wir damals arbeiteten, des Abschnitts $\mathrm{g}^{\mathrm{m}}$ Knechte Gottes" noteerde Buber (Buber 1979", 44). Het betreft hier het met betrekking tot de situatie van Rosenzweig wel heel indringen- 
de hoofdstuk dat - in de vertaling van Buber en Rosenzweig - begint met de woorden:

"Wer konnte vertrauen dem für uns Erhorchten? SEIN Arm,

an wem hat er sich da offenbart?!

Wie ein Keimling stieg er auf vor sich hin, wie eine Wurzel aus dürer Erde, nicht Gestalt hatte er, nicht Glanz, dass wir ihn angesehn hätten, nicht Aussehn,

dass wir sein begehrt hätten, Von Menschen verschmäht, gemieden, ein Mensch der Schmerzen,

der Krankheit bekannt,

wie wenn das Antitz sich vor uns verbergen muss:

so verschmäht -

wir achteten sein nicht" (Jeschajahu 53,1-3). Rosenzweig kon de vertaling van de Hebreeuwse bijbel niet afmaken. Dit werd door Buber gedaan. Ook zijn laatste brief die hij nog aan Martin Buber aan het schrijven was, kon hij niet voltooien. De laatste woorden hiervan zijn: "und jetzt kommt sie, die pointe aller Pointen, die der Herr mir wirklich im Schlaf verliehen hat: die Pointe aller Pointen für die es..." (Rosenzweig 1935,633;id.,1979, Bd. 2,1237). "Franz Rosenzweig starb am 10. Dezember 1929 nachts um 2 Uhr im Jahre der Schöpfung 5690" (id.,1979, Bd.2,1237). Hij werd op het nieuwe joodse kerkhof in Frankfurt am Main begraven. Op zijn grafsteen staat in het Hebreeuws: "Und doch bleibe ich stets bei Dir" (Psalm 73,23). Ook op de grafsteen van Martin Buber in Jeruzalem is dezelfde tekst te lezen.

$2 \cdot 5$. Enkele aantekeningen.

In het eerste hoofdstuk heb ik uitgewerkt, dat het woord gezond een ruime betekenis kan hebben. Ook heb ik aangegeven dat iemand zich an- 
tropologisch, dat wil zeggen als mens gezond kan voelen, terwijl hij toch lichamelijk ziek en/of gebrekkig kan zijn. Franz Rosenzweig was zo iemand. Terwijl hij lichamelijk ziek was, bleef hij geestelijk gezond. En zelfs meer dan dat: hij bleef tot het laatste moment aktilef bezig. Bovendien bleef hij mondeling en vooral schriftelijk in kontakt en in gesprek met andere mensen, onder andere met Martin Buber. Terwijl iedereen met hem te doen had, merkte Rosenzweig zelf op: "Man halt mich fur unglicklich. Man bemitleidet mich. Dazu hat keiner das Recht. Niemand weiss, ob ich nicht vielleicht glicklich bin. Das weiss nur ich" (Koch, in Rosenzweig 1979,Bd.2,822). Maar deze houding om Rosenzweig met zijn ziekte ook als ziek te beschouwen had niet iedereen. Ernst Simon, een goede vriend en regelmatig bezoeker, noteerde zeer terzake: "Nie habe ich einen gesunderen Menschen gesehen" (Simon $1930,37)$. Na een bezoek van de neuroloog prof. ottfried Förster schreef Rosenzweig aan diens assistent met betrekking tot het menselijke aspekt van zijn ziekte: "Er (Förster) wirde hier bei mir mehr lernen als lehren können" (Rosenzweig 1979, Bd.2,944). En tegen Martin Buber had hij zich laten ontvallen: "Ihr wisst doch nicht, was ich habe, ich bin ja der Kranke" (id.,943). Rosenzweig bedoelde hiermee aan te geven, dat de arts zich niet alleen met de strikt medische kant en met zijn ervaring in deze bezig te houden heeft, mar ook met de individuele persoon - zo blijkt uit het vervolg van deze brief.

Van essentiếl belang is niet alleen de vraag of iemand een klacht of een ziekte heeft, maar vooral ook wat dat voor iemand betekent met betrekking tot zijn mens zijn. Een ziekte heeft voor de patient meestal niet dezelfde betekenis als voor de arts. Schouten spreekt van "een hiaat in het medisch vraaggesprek" als aan dit menselijke aspekt geen of onvoldoende aandacht wordt besteed (Schouten 1982, 44-57). Ik meen dat het hier om een belangrij- 
ke, in de medische praktijk nog weinig onderkende en toegepaste, zaak gaat.

Naar aanleiding van het zo juist genoemde bezoek van Förster, warbij ook de psychiater en internist Viktor von Weizsäcker en Martin Buber a anwezig waren, liet Förster zich ten overstaan van hen ontvalien: "Dieser Mann ist ein Held". Hierop reageerde Von Weizsäcker met: "Nein dieser Mann ist ein Jude" (bij Rosenzweig 1979,Bd.2,943; vgl.Badt-Strauss 1930, $7)$. Door dit te citeren wil ik niet suggereren, dat elke jood een held is. Van belang is, dat het een erkenning betreft van Rosenzweligs persoonlijke keuze voor het jodendom. Rosenzweig had ervaren dat gezond (= heel) mens zijn voor hem samenhing met zijn jood zijn. "Das einzig Gesunde, das einzig noch Ganze am judischen Menschen ist der juidische Mensch selber", schreef hij in "Bildung und kein Ende' (Rosenzweig 1937,86-87).

Wat zijn eigen mens zijn betreft, heeft Rosenzweig ontdekt, dat dit samenvalt met zijn jood zijn. Over dit laatste schreef hij: "Man ist es (...). Aber freilich: auch es ist" (Rosenzweig 1937,82). Daarmee was zijn jood zijn voor hem van een veel grotere kracht en van een heel andere dimensie dan de Duitser Duitser of de Fransman Fransman is. Jood zijn is geen nationaliteit die je kunt verkrijgen, of opgeven, het is ook geen geloof dat je kunt aannemen of achter je laten, geen opvatting die je je eigen kunt maken of weer verwerpen. Voor het jood zijn ligt dit anders: "als Jude ist er Mensch, als Mensch Jude. (...). Jeder spürt, dass der Jude nicht ein abgegrenztes stick in ihm 1st, sich abgrenzend gegen andres Abgegrenztes, sondern eine seis nun grosse, seis geringe Kraft, die ganzes Wesen trăgt und durchströmt" (id.,81).

In de periode rond 1913 en beinvloed door de ervaringen van de eerste wereldoorlog werd Rosenzweig zich de krisis van de westerse 
kultuur en van het westerse weten ten volle bewust. Met betrekking tot het existentiële vakulim (Frankl, zie 1.3) dat hij in zijn eigen tijd konstateerde en ook persoonlijk aan den lijve ervoer " bracht Rosenzweig het perspektief van een "nieuw denken" en van een "nieuw leren'. In beide situaties sloot hij aan bij het in de joodse traditie opgeslagen gedachtengoed. Het nieuwe denken werkte Rosenzweig met name uit in "Der Stern der Erlösung"; een moeilijk en vaak weerbarstig boek. Maar ook een boek dat voortdurend weer nieuwe perspektieven blijkt te geven. De essentie van dit boek heb ik in grote 1 ijnen in dit hoofdstuk trachten uit te werken.

Het nieuwe leren heeft Rosenzweig vooral in het leerhuis in praktijk gebracht. Bovendien heeft hij de essentie ervan in enkele artikelen aangegeven. Zowel met betrekking tot het nieuwe leren als met betrekking tot het nieuwe denken is belangrijk, dat het niet om een specifiek joodse methode en om een specifiek joods denken gaat, maar om een wijze van leven en om een filosofie die vóór-al menselijke ervaring is en die daarmee van betekenis is voor gezond (heel) menselijk leven en voor menselijkheid.

In zijn inleiding op de door Nahum Glatzer verzorgde uitgave van het door Rosenzweig geschreven "Das Blichlein vom gesunden und kranken Menschenverstand' geeft Nahum Glatzer de basisopvattingen van Rosenzweigs dialogisch denken als volgt weer: "Das Judische, wie Rosenzweig es auffasst, ist die Betonung der konkreten menschlichen situation, die wichtigkeit des gesprochenen Wortes und des Zwiegesprachs, die Erfahrung der zeit und ihres Rhythmus (und im zusammenhang damit, die Fahigkeit zu warten), und endich die tiefe Bedeutsamkeit des Namens, des menschlichen wie des göttlichen" (Glatzer, in Rosenzweig 1964, 19).

In plaats van op het denken begon Rosenzweig de nadruk op het spreken te leggen. "Das Den- 
ken is zeitlos, will es sein; es will mit einem Schlag tausend Verbindungen schlagen; das Letzte, das ziel ist ihm das Erste. Sprechen ist zeitgebunden, zeitgenahrt; es kann und will diesen seinen Nahrboden nicht verlassen; es weisz nicht im Voraus, wo es herauskommen wird; es läszt sich seine stichworte vom andern geben. Es lebt iberhaupt vom Leben des anderen" (Rosenzweig 1937,386-387). Daarom, zo zou ik hieraan willen toevoegen," behoort ook de konsultvoering van de arts, nadat de patiënt zijn probleem verteld heeft, niet met een monologisch denkproces van de arts te beginnen, mar met een gezamenlijke exploratie door arts en patiënt van de aard en de betekenis van het probleem. En na dit tweegesprek kunnen beiden in samenspraak met elkaar een afspraak maken over de aard van de te verlenen en te verkrijgen hulp en over de wijze waarop die bereikt kan worden.

Alleen in een echt gesprek, waarbij - met behoud van de eigen deskundigheid van de arts -, de arts de patiënt als werkelijke partner ziet en omgekeerd, kan de patiënt werkelijk geholpen worden. Rosenzweig: "Im wirklichen Gespräch geschieht eben etwas; ich weiss nicht vorher, was mir der andre sagen wird, weil ich nämlich auch noch nicht einmal weiss, was ich selber sagen werde; ja vielleicht noch nicht einmal, dass ich uberhaupt etwas sagen werde; es könnte ja so sein, dass der andre anfängt, ja es wird sogar im echten Gespräch meist so sein. (...). Der Denker weiss ja eben seine Gedanken im Voraus; dass er sie "ausspricht', ist nur eine Konzession an die Mangelhaftigkeit unsrer, wie er es nennt, Verständigungsmittel; die nicht darin besteht, dass wir sprache, sondern darin, dass wir zeit brauchen. Zeit brauchen heisst: nichts vorwegnehmen können, alles abwarten müssen, mit dem Eigenen vom andern abhängig sein. Das alles ist dem denkenden Denker völilg undenkbar, während es dem Sprachdenker einzig entspricht" (id.,387). Ook van de huisarts wordt verlangd, 
dat hij 'sprachdenker' is.

In Rosenzweigs leven is niet zijn ziek zijn het belangrijkste gebeuren, mar - ik zei dit hiervoor al - het existentielle vakulim dat hij aan den lijve ervoer in 1913. Toen viel voor hem de beslissende keuze voor een wat zijn hele menselijke existentie betreft gezond of niet gezond leven. Zijn gesprekspartner uit die tijd, Eugen Rosenstock, schrijft meer dan vijftig jaar later, dat toen, in 1913, de kiem voor 'Der stern der Erlösung', gelegd is, een kiem die door zijn toedoen tot stand gekomen is (Rosenstock-Huessy 1968,171).

Wat van dit laatste ook waar moge zijn, het eerste blifft in elk geval overeind staan: 1913 was een beslissend jaar voor Rosenzweig persoonlijk en daarmee voor de aard en strekking van het werk, dat hij zou gaan verrichten. Over de diepte van deze levenskrisis weten we zo goed als niets. In een brief a n zijn promotor Friedrich Meinecke laat Rosenzweig er voorzichtig iets over los, wanneer hij toelicht warom hij zich niet meer met de wetenschap als een op zichzelf staand doel wil. bezighouden, maar bovenal door mensen aangesproken wil worden en niet door geleerden. In deze brief zegt hij over die levenskrisis: "Mir ist im Jahre 1913 etwas geschehen, was Ich, wenn ich einmal davon reden soli, nicht andres bezelchnen kann als mit dem Namen: Zusammenbruch. Ich fand mich plotzlich auf einem Trummerfeld oder vielmehr: Ich merkte, dass der Weg, den ich ging, zwischen Unwirklichkeiten dahinfuhrt" (Rosenzweig 1979, Bd.2, 679).

Als ik op dit punt een verbinding met de geneeskunde meen te moeten leggen, dan betreft dit vooral de levensloopgeneeskunde (zie hoofdstuk 5). In het leven van mensen kunnen zich gebeurtenissen voorgedaan hebben - en deze hoeven niet duidelijk en direkt kenbaar te zijn - die beslissend zijn geworden voor iemands leven. Het kan tot de biografische 
anamnese behoren deze gebeurtenissen te traceren.

Het "Sprachdenken' van Rosenzweig valt niet tot een bepaald vakgebied terug te brengen. Het is grensoverschrijdend van karakter en het biedt voor vele disciplines een ingang: niet alleen voor filosofen, maar ook voor sociale wetenschappers. Voor geen van alle biedt het echter een afgerond systeem. Het lat ingangen zien en wie eenmal binnen is kan nog vele kanten op.

De psycholoog komt in eerste instantie wel1 icht het beste uit de voeten met wat Rosenzweig in het eerste deel van 'Der Stern der Erlösung" over de mens zegt. Hier is de mens als zodanig aan de orde. In het tweede deel spreekt Rosenzweig over de mens in zijn dialogisch-relationele situatie. Hier zal de andragoloog vanuit zijn betrokkenheid op de andragogische situatie - een situatie van mensen met elkar - een invalshoek kunnen vinden. Het was het deel dat mij het meeste aansprak. Ook de huisarts zal hier het vertrekpunt van zijn denken en handelen vinden. De socioloog, in zijn gerichtheid op sociale verschijnselen, vindt wellicht in het derde deel, het deel warin onder andere de ordening van de tijd en van de gemeenschap aan de orde is, het beste zijn weg.

Een interessante vraag is nog of Rosenzweig datgene wat wij sociale verschijnselen noemen tot het 'element' 'wereld' of tot het 'element' 'mens' zou rekenen. Van de wereld zegt hij dat de dingen telkens weer te voorschijn komen. Dit kunnen we ook van de sociale verschijnselen zeggen. Zonder de wereld kan de mens niet leven. zonder sociale strukturen evenmin. De dingen van de wereld zijn evenmin blijvend als de sociale strukturen. Maar wel komen ze steeds weer te voorschijn en ontwikkelen zij zich voortdurend. Met de mens is dit niet het geval, het menselijke zelf in zijn uniciteit is vergankelijk, het is specifiek 
eenmalig, de menselijke soort niet. Deze maakt 'als soort' deel uit van de wereld. Het typisch menselijke moment, "das selbst" zoals Rosenzweig dit in het eerste deel beschrijft en 'die von Gott wachgerufene seele' - het antropologisch relevante moment in het tweede deel -, zijn niet aan de fysieke en procesmatige verschijnselen van de wereld ondergeschikt. Daarenboven kent de mens, zo zegt Rosenzweig, de vrijheid van wil; een vrijheid die door het gebeuren van de openbaring alleen maar bevestigd wordt. Dit kenmerk nu ontbreekt aan het sociale verschijnsel (zie Schaeffler 1979,55-56). Het is de mens die de sociale verschijnselen richting geeft. Ik moet overigens aantekenen, dat de levensordening zoals de joodse traditie die kent op basis van de sabbat, wel een blijvend karakter heeft. Deze overschrijdt elke immanente en natuurlijke orde. Ik verwijs voor de uitwerking naar hoofastuk 5 .

Een laatste aantekening. De weg die 'ins Leben" voert, zoals Rosenzweig op de latste bladzijde van 'Der Stern der Erlösung' zegt, is voor hem de weg van de joodse traditie, de weg van de Torah. Deze weg is, zegt Amir, in ons allen latent aanwezig (Amir 1979 , 165). Dit geldt voor de jood. De niet-jood kan, zo hij wil, de joodse traditie tegemoet treden, niet in en vanuit zichzelf, maar wel vanuit de presentle van de Torah en de joodse traditie door de geschiedenis heen.

In de joodse traditie - en hierover gaat dan het volgende hoofdstuk - staat niet God centraal, maar de aan de mens gegeven Torah. Van belang is dat de Torah gegeven is, belangrijker nog dat de mens de Torah aangenomen heeft (v1g.Rosenzweig $1979, \mathrm{Bd} .2,977$; verder id.,978 en $1039-1040)$. Het teken, warin Rosenzweig God, wereld, mens in het eerste deel van 'Der Stern der Erlösung' plaatste, krijgt zo een op de mens gericht aksent. De gelijkzijdige ariehoek met de punt naar boven ziet er dan 
als volgt uit:

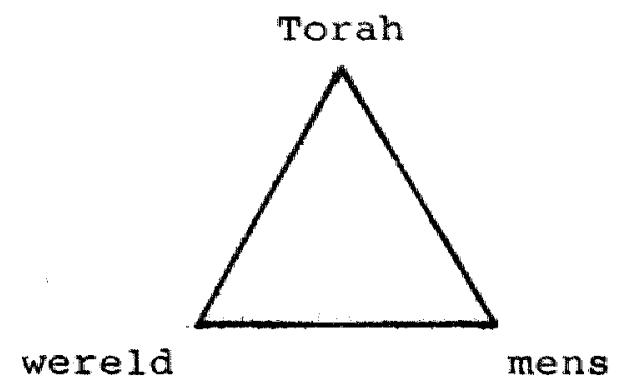

Ik moet hierbij aantekenen, dat ook de elementen wereld en mens verder gespecificeerd kunnen worden. Ik beperk me ertoe dit hier kort aan te duiden en niet uit te werken. De aanduiding spreekt voor zich en de uitwerking gebeurt impliciet in dit boek. De Miranda noemt drie fasen die hij schematisch uitwerkt. (De Miranda 1968,53 en 82). Deze schema's heb ik aangevuld en ik breng hen als volgt tot één schema terug:

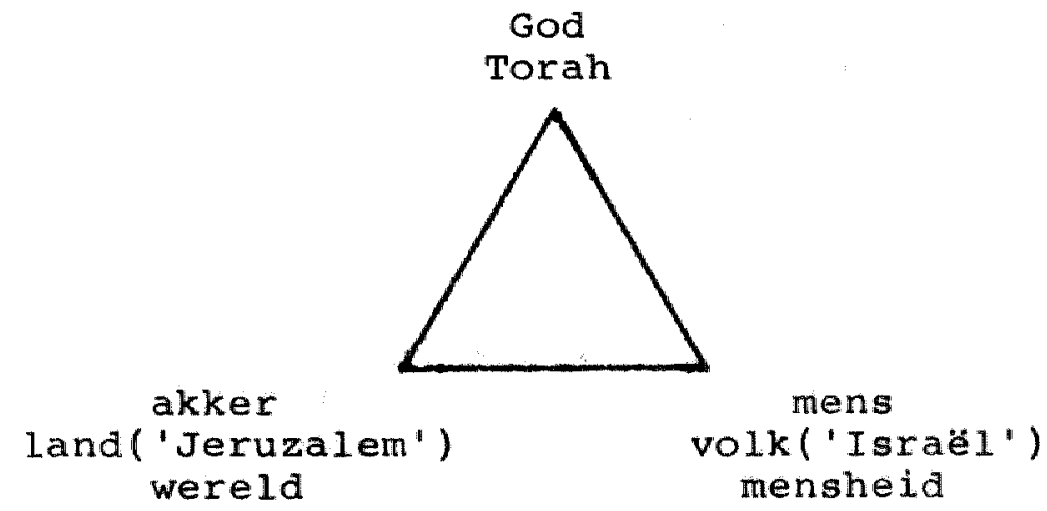


HOOFDSTUK 3: JOODSE TRADITIE.

Meer dan de filosofisch-joodse heeft de rabbijnse denkwijze het jodendom een geheel eigen karakteristiek gegeven (zie Petuchowski 1983). De achtergronden ervan gaan tot ver in de geschiedenis terug. Hoewel het jaar 70, met de verwoesting van de Tweede Tempel en van de stad Jeruzalem door de Romeinen, volgens de traditie beslissend is voor het rabbijnse jodendom (Neusner 1974,11-12), is de anzet ertoe van oudere datum. In 70 eindigde de afhankelijkheid van de Tempel en van de hierbij horende kultus. Al eerder echter werd de Tempel van salomo verwoest en eindigde de afhankelijkheid van de toenmalige staatkundige vorm van Israë 1 (587-586 v.Chr.)

$\mathrm{Na}$ de terugkeer van de joden uit Babyloniè (vanaf $538 \mathrm{v} . \mathrm{Chr}$.) was er van een wereldlijk centrum geen sprake meer. De Tweede Tempel werd het nieuwe geestelijk centrum. Daarnaast ontstond in het interpreteren van de Torah met het oog op het leven en de dagelijkse levensordening in een geheel nieuwe situatie al een eerste aanzet voor het rabbijnse jodendom, zoals dit vanaf het jaar 70 tot het traditionele jodendom, tot joodse graditie geworden is (zie o.a. Safrai $1978,1980^{2}$; Goldman 1975).

De redding, in het jaar 70 , van het jodendom en van het levenskonsept zoals dat in de traditie van de Torah overgeleverd was, wordt toegeschreven an Jochanan ben Zakkai (zie Enc.Jud., vol.10,152-153). Beter dan de heldendood te sterven of de heiliging van het martelaarschap te ondergaan, achtte hij het de Torah te laten voortleven. Daarom zocht hij naar een weg warin joods leven in een nieuwe vorm bewaard zou kunnen blijven en wargemaakt kan 
worden. Het verhaal is overgeleverd dat Jochanan ben Zakkai zich door zijn treurende leerlingen in een lijkkist buiten de stad liet smokkelen en zo een leerschool in Jamnia (Javne) kon stichten (Keller z.j.,78-79;Grayzel 1968,184;ARN IV, 35-37). Rabbi Jochanan ben zakkai redde zo niet alleen $z i j n$ eigen $10-$ ven en dat van $z i j n$ leerlingen, maar hij redde ook, en dit in de eerste plaats, de Torah (Neusner 1980,55$)$. Daarmee redde hij voor het mens zijn essentiële levenskonsepten (zie Seltzer 1980,245$)$.

Het kernverhaal in de joodse literatuur is de in de Torah verhalde gebeurtenis van de uittocht uit Egypte. Deze gebeurtenis met alles wat daar omheen plaats vond en met alles wat er tot in onze tijd op volgde, staat tot op de dag van vandaag borg voor het jood zijn (Friedlander 1978,32). Rosenzweig spreekt van de "ewig gegenwărtige Erinnerung", en hij vervolgt met de woorden uit de seder-Haggada: "jeder Einzelne soll den Auszug aus Egypten so ansehen, als wăre er ${ }_{4}$ selbst mit ausgezogen" (Rosȩnzweig $1921,1976^{4}, 337 ; z i e$ Haggada 5731, $\left.5743^{3}, 55\right)$.

Het voert te ver hier uitvoerig op dit gebeuren in te gaan. Het betreft een in grote lijnen bekend verhaal (vgl.Jacobson 1982). Van belang is dat voor het eerst in de geschiedenis van de mensheid werkelijk nieuwe en verder uniek gebleven basiskonsepten met betrekking tot de mens en zijn wijze van leven aan de orde zijn (Von Weizsäcker 1966,55-56). "De theologische, morele en politieke implikaties van deze grote gebeurtenis maken het verhaal van de uittocht tot een onderricht of tora, een leerprogramma of agenda voor de mensheid" (Maccoby 1980,54-55).

Door de bevrijding uit Egypte - "de centrale gebeurtenis in de joodse geschiedenis" - leert de mens wat het betekent om vrij te zijn, orn "volledig mens te zijn" (Fromm 1975,133). De belangrijkste levensrichtlijn van het uit- 
tochtverhaal is dat de mens noch aan de natuur noch aan een andere mens ondergeschikt is en dienstbaafheid verschuldigd is (zie Cassuto $\left.1951,1974^{6}, 236\right)$. De joodse identiteit wordt gekenmerkt door het afzweren van elke vorm van afgodendienst met als konsekwentie het op een geheel eigen wijze - de wijze van de Torah op weg gaan door het leven.

Het jodendom is een wijze van leven; het is geen godsdienst. Ook aan nationale of staatkundige kategorieên moeten we niet primair denken (Bein 1980,2;vlg.Boon 1974,8). "Judaism is not just an aspect of the Jew's life; it is the totality of it" (Hurwitz 1978,1981",51; vgl.Rosenzweig 1937,81-82). Het is iets dat overal en op elk moment aanwezig is. Alle facetten van het dagelijkse leven zijn nauwgezet uitgewerkt, beschreven, opnieuw getoetst en weer beschreven. Deze levensweg, de 'halacha' is voor de jood richtlijn 'ten leven'.

De halacha die de jood zijn identiteit doet houden, geeft niet alleen aan wat het is om jood te zijn, maar zij schrijft ook voor wie jood is. Soetendorp: "De traditionele definitie werd dat wie uit een joodse moeder geboren was Jood of Jodin was. Ieder ander kon als 'oprechte bekeerling" tot de Joodse gemeenachap toetreden wanneer de 'oprechtheid' vaststond en hij of $z i j$ aan de daarvoor gestelde voorwarden had voldaan. Het al of niet naleven van de wetten en bepalingen van wat door Torah en traditie werd voorgeschreven, was voor hem of haar, die als Jood geboren was, niet van invloed op het Jood-zijn. 'Ook a 1 faalt hij, hij blijft Israel' (Talm.Bab., Sanhedrin 74a). Zie bijvoorbeeld de plaats in de Talmoed (Avodah Zarah 26b): "Ook de renegat in godsdienstig opzicht blijft uw broeder" (Soetendorp 1970, 14). Halachisch is een jood dus iemand die geboren is uit een joodse moeder mar ook degene die tot het jodendom is overgegaan en als zodanig geaksepteerd is. De proseliet is in de volle zin jood. 
Alhoewel in orthodox-halachische zin het strikt naleven van alle wetten en bepalingen een vereiste is, is er daarnaast het kriterium van 'oprechtheid' dat iemand tot jood makt. De journalist Herman Bleich merkte eens op, dat een jood iemand is die van zichzelf vindt dat $h i j$ jood is, omdat hij $z i c h$ met de joodse traditie onder alle omstandigheden verbonden voelt. Verbonden zijn met de joodse traditie wil zeggen: verbonden zijn met de traditie van de Torah. Ook Petuchowski denkt in deze richting. Wie ernst makt met het leven, dat wil zeggen wie juist leeft en (daardoor) rechtvaardig handelt, met andere woorden wie afgodendienst afzweert en geen andere goden naast de Ene God erkent, is een "Jehudi", een jood (Petuchowski 1983).

Uit de opvattingen van Bleich en Petuchowski zou men de gevolgtrekking kunnen maken, dat ook een niet-jood die afgodendienst afzweert en rechtvaardig leeft, 'jood' zou kunnen zijn. Alhoewel er aanwijzingen zijn dat in het bijbelse en talmoedische jodendom mensen op deze wijze zich bij de joodse traditie aansloten, kan men dit toch niet als regel aanhouden. Het joodse volk blijft 'apart'. Wel leert de rabbijnse traditie dat een niet-jood die de afgodendienst afzweert, een 'rechtvaardige' is en dat hij een aandeel in de 'komende wereld' zal. verkrijgen - zo luidt hiervoor de uitarukking in de rabbijnse literatuur (Tosephta Sanhedrin 13,2 , bij Petuchowski 1980,233). De Talmoed zegt: "Is it not taught: R. Meir used to say. "Whence do we know that even an idolater who studies the Torah is equal to a High Priest? From the following verse: "Ye shall therefore keep My statutes and My ordinances which, if a man do, he shall live by them' (Lev.XVIII,5). It does not say "If a Priest, Levite, or Israelite do, he shall live by them', but 'a man'; here then, you can learn that even a heathen who studies the Torah is equal to a High Priest!" (Bab.Talm. Abodah Zarah 3a; id. Baba Kamma 38a;id., Sanhedrin 59a). 
Joodse traditie en Torah.

$3 \cdot 2 \cdot 1$. Torah.

Het ervarings- en gedachtengoed van de joodse traditie vindt tot op de huidige dag zijn neerslag in een onafzienbare rij van verhalen en van wetenschappelijke literatuur. De bron van dit joodse weten is de Torah. "The Torah is the foundation of Judaism. Without it, Judaism cannot exist" (Kaplan 1979,121). In 'Der Stern der Erlösung' zegt Rosenzweig: "Thora, sie Lernen und Halten, ist die allzeitgewärtige Grundlage eines juidischen Lebens" (Rosenzweig 1921,1976,362).

Bij het woord 'Torah' wordt meestal eerst gedacht aan de eerste vijf boeken van de Hebreeuwse bijbel: de vijf boeken van Mozes, ook

'Pentateuch" of 'Choemasj', letterlijk 'de vijf', genoemd. Daarnaast bestaat de Hebreeuwse bijbel als een geheel. Deze bevat de delen 'Pentateuch" plus 'Profeten' plus 'Geschriften'. Het gebruikelijke woord hiervoor is 'Tenach' of TeNaCH, naar de beginletters van de woorden 'Torah', 'Neviejiem' (Profeten) en 'CHtoewiem' (Geschriften). Buiten het jodendom wordt meestal van het ${ }_{3}$ Oude Testament gesproken (zle Jacobs $1957,1965^{3}, 57-59$ ).

Het woord 'Torah' wordt in onze westerse kultuur over het algemeen vertaald met 'wet'. De vertaling 'wet' is echter niet uit het Hebreeuws overgenomen, mar het is de vertaling van het Grilekse 'nomos'. Dit woord 'nomos' komt voor in de septuaginta, de belangrijkste vertaling van de Hebreeuwse bijbel in het Grieks (ca.250-ca.132 vóór onze jaartelling). In letter en geest heeft deze vertaling aran de basis gestaan van de latere westerse vertalingen (Musaph-Andriesse 1973,18-19; Urbach 1975, 
1979, 288-290; vg1.Safrai 1978, 1980, 82).

Deze ontoereikende vertaling van Torah als wet is de basis van een onterechte kwalifikatie van de Torah en de joodse traditie als $5^{\text {dogma- }}$ tisch-legalistisch (Schechter $1961,1975^{5}, 117$ ). $\mathrm{Nu}$ is ook in de joodse traditie het bindend karakter van de Torah niet onbekend, mar het heeft daar niet zo"n negatieve lading. De verplichtingen worden in de joodse traditie meer gezien als konkrete door de levenssituatie van de mensen opgeroepen morele verplichtingen (vgl.Enc.Jud., Vol.10,1480-1484). Een dergelijke verplichting tot handelen duldt men aan met het woord 'mitswa' dat gebod of goddelijke opdracht betekent (zie hoofdstuk 6).

De Torah is veel meer een blauwdruk voor het leven (vgl. Neusner 1965,19 ) dan een (goddelijk) wetboek of een theologisch of filosofisch systeem. "The Torah is a continuous guide to life" (Goldman 1975,63). En Heschel merkt op: "The domain of the Torah is (therefore) all of life, the trite as well as the sacred" (Heschel 1951,19772,270). De Torah beoogt geen dogmatiek te zijn, maar 'lering'. "Het jodendom is niet een abstrakte, filosofische leer, maar een 'Torat Chajjiem': een levensleer" (Hamel 1981,33).

Het is deze betekenisnuance, 'levensleer', die de aard en de strekking van de Torah het meest nabij komt. Een betere vertaling dan 'wet' is '(levens)leer' of 'lering'. Ook woorden als 'onderricht', of "aanwijzing" geven beter aan wat de Torah bedoelt te zijn dan het woord "wet" (vgl.De Boer 1976,139). Martin Buber en Franz Rosenzweig spreken in hun vertaling van de Hebreeuwse bijbel in het Duits van "Weisung'. Soetendorp spreekt van "aanwijzingen ten leven" (Soetendorp 1970,145), Abram van 'gedragsregels' (Abram 1980,76). "Weisung' wijst de mens de weg die hij moet gaan. "Weisung' geeft de mens richtlijnen "ten leven' en zegt hoe de mens moet handelen om juist en gaaf te (leren) leven (zie Ex.18:20;Ex.33:13; Ps.16:11). "Torah" of "Weisung" betekent voor 
de joodse traditie de juiste weg. Het is ook een voor Israël geheel eigen, een bijzondere en aparte weg (vgl. 0.a. Buber 1923,143-197). Torah betekent dus zowel 'onderricht' als "levenswijze'. "Torah is de leer die geleerd en onderwezen wordt" (Abram 1980,76). Torah wil zoveel zeggen als "onderricht bij ultstek" (Epstein 1964,25). De lering van de Torah heeft op het leven betrekking: "Met Torah wordt meer een manier van leven (way of life) bedoeld dan een denksystematiek (system of thought)" (Abram 1980,25). En Heschel leert: "The Torah is primarily divine ways rather than divine laws" (Heschel 1955,1976,288).

Als ik Torah aanduid als "levensleer" wil ik hiermee aangeven, dat deze leer en lering het realiseren van de mens ten goede komend leven beoogt. "Torah tells us what we really are or can become" (Neusner 1980,116). In de Torah staan aanwijzingen die voor de mens in alle opzichten gezond (= gaaf) leven betekenen. "Keeping the divine law is the most preventive medicine against all physical and social evil" (Hirsch 1976, Vol.II,207).

Leren kennen van de Torah leidt, merkt Neusner op, tot een beter inzicht in de innerlijke struktuur van de werkelijkheid en tot een beter begrip van de werking ervan. Dit is van direkte invloed op het gedrag (Neusner 1973, 3).

Heel de werkelijkheid, alles, heel het leven, is in de Torah vervat: "Wat de Joden in de Torah zoeken zijn niet alleen mar bepalde warheden en is ook niet alleen mar een manier van leven of alleen maar levenswijsheid, mat letterlijk genomen "alles" (Abram 1980, 76). "The Torah was (in short), all things to a11 men" (Schechter 1961,1975, 135 ). In de Talmoed staat dat geen profeet iets nieuws kan leren, dat niet reeds in de Torah staat (Bab. Talm. Shabbath 104a; v1g.Ben-Chorin 1975,19792, 167). En in de Misjna is een tekst, die zegt: "Jochanin ben Bag Bag said: turn it (the To- 
rah) over, and (again) turn it over, for all is therein. And look into it; and become grey and old therein; neither move thou away therefrom, for than it thou hast no better standard of conduct" (Mishnah, Aboth V,22).

In de Torah wordt verhald dat de Torah tijdens de uittocht uit Egypte aan Mozes en het gehele volk Israël werd gegeven (Ex.19:23). De rabbijnse traditie zegt dat Mozes op de berg SinaI de Torah ontving (Mishnah, Aboth $I, 1$ ). "God revealed the Torah through Moses" (Kaplan 1979,121). De traditie beschouwt dit gebeuren - dat Heschel beschrijft als "a great event, miraculous as it may be, 3 if it happened only once" (Heschel 1955,1976 326 ) - als een geschenk van de levende, Ene God. God heeft de Torah geopenbaard.

Deze gebeurtenis gaat het menselijk voorstellingsvermogen te boven. Naar een weten achter de Torah kan dan ook niet gevraagd worden.

De Torah, Gods blauwdruk voor de wereld, is door deze openbaring een zaak geworden war de mensen verantwoordelijk voor zijn. De Talmoed warschuwt er dan ook voor dat op hemelse stemmen geen acht geslagen mag worden (Bab.. Talm., Baba Mezi'a 59b). De Torah is niet meer in de hemel, maar bij de mensen (vgl.Midrash Rabbah, Deut.R.VIII, 6).

Dit gelat voor de gehele Torah. "The gift was a complete one, without any reserve whatever. Nothing of the Torah. God assures Israel was kept back in heaven. All that follows is only a matter of interpretation. (...). The Torah came down from heaven with all the necessary instruments: humility, righteousness, and uprightness - and even her reward was in her. And man has only to apply these tools to find in the Torah peace, strength, life, light, bless, happiness, joy, and freedom (Schechter $\left.1909,1975^{5}, 134-135\right)$.

De rabbijnen merken met betrekking tot het feit dat de Torah in de woestijn is gegeven, het volgende op: "The Torah was given in 
public, openly in a Eree place. For had the Torah been given in the land of Israel, the Israelites could have said to the nations of the world: You have no share in it. But now that it was given in the wilderness publicly and openly in a place that is free for all, everyone wishing to accept it could come and accept it" (Mekilta,Vol.II,198). De Torah en de levensaanwijzingen die de Torah geeft zijn niet voorbehouden aan een bepalde groep. Zij zijn er voor iedereen (zie Goldman 1975,50).

De Torah is voor de jood het vooronderstelde (zie hoofdstuk 1) dat de mens tot weten brengt. Een legende verhalt dat zelfs God in de Torah keek toen hij de wereld en de mensen schiep (Enc.Jud., Vol.15,1236;zie Ginsberg 5727 $-5730 / 1967-1969, V o 1 . I, 3)$. En in de oude rabbijnse literatuur wordt geleerd, dat de Torah een van de zeven zaken is, die voorafgaan aan de schepping van de wereld (Midrash Rabbah, Gen.R.I.4). De joodse filosoof Philo van Alexandrië ( $\pm 20 \mathrm{v} . \mathrm{Chr} .-50 \mathrm{na}$ Chr.) trekt uit de pre-existēntie van de Torah de konklusie dat Gods Woord en de Torah identieke zaken zijn (Wigoder 1974,98; Enc.Jud., Vol.15,1236; vgl. Enc.Jud. , vol.13,412-413).

De pre-existentie van de Torah heeft veel joodse geleerden bezig gehouden - tot in onze eeuw toe (zie Wigoder 1974,98-101; Enc.Jud., Vo1.15, 1236-1238). Zo zegt Franz Rosenzweig in 'die Bauleute': "Gewiss war die Tora, schriftliche wie mulindiche, dem Mose am Sinai gegeben, aber war sie nicht vor der welt geschaffen? Mit Buchstaben finstern Feuers auf einen Grund von lichtem Feuer geschrieben? Und war nicht um ihrentwillen die Welt geschaffenl" (Rosenzwelig 1937,$111 ;$ ook id.,1955,78). 
Volgens de joodse traditie is er niet één Torah, mar zijn er twee: de "geschreven" en de "mondelinge Torah". "It is related that a certain man stood before Shammai and said: 'Rabbi. how many Torahs have you?' The Rabbi replied: "Two - one written and one oral"" (Bab.Talm., Shabbath 31a:ARN XV,61).

De schriftelijke Torah - in het Hebreeuws de "Torah sjebichtav" - bevat de eerste vijf boeken van de Hebreeuwse bijbel, de boeken van Mozes. De mondelinge Torah - in het Hebreeuws de 'Torah sjebe'alpeh' - bestaat uit nadere toelichting en uit de aanwijzingen, kommentaren, verklaringen, interpretaties en bewerkingen die tezamen en tegelijkertijd met de schriftelijke Torah overgeleverd zijn. Vaak gebruikt men alleen hiervoor de term (joodse) traditie. "Tradition is the name applied to the unwritten code of law given by God to Moses on Mount Sinai" (Wigoder 1974,38;Enc. Jud. . Vol.15,1308).

'Joodse traditie" of. 'Torah-traditie' wordt echter ook in een meer omvattende betekenis gebruikt en heeft dan zowel op de schriftelijke als op de mondelinge Torah betrekking. "De woorden 'joodse traditie' en 'Torah' zijn verwisselbaar", zegt Abram (Abram 1980,76). ook ik bedoel in deze studie met de joodse traditie de schriftelijke en de mondelinge traditie tezamen.

Mozes ontving op de berg sinat de Torah in zijn gehee1. God openbaarde niet alleen de schriftelijke Torah, maar ook de mondelinge. "Torah is the written and oral heritage of our Jewish forefathers, which has existed since before the world began and was given in the present form to the Jews at Har (Mgunt) Sinai, 3300 years ago" (Hurwitz 1978,1981,20-21).

op het moment warop God de Torah openbaarde en deze Mozes in handen legde en waarop Mozes de Torah aannam (zie ook Ginzberg,Vol.III, 5728 $-1968,80-81$ ) moest het volk Israell direkt a met de Torah leven. Op hetzelfde moment begon 
de interpretatie en bekommentariëring ervan. "God gave Moses an oral explanation of the Torah along with the written text" (Kaplan 1979,177). Dit was nodig ondat aanwijzingen in de schriftelijke Torah lakunes bevatten en zij niet altijd expliciet zijn uitgewerkt (Enc. Jud., Vol.12,1439); met andere woorden details ontbreken soms of worden bekend verondersteld (dat wil zeggen de mondelinge traditie is ervan op de hoogte). (Kaplan 1979,177-178). ook bevat de schriftelijke Torah niet voor alle tijden, plaatsen en situaties duidelijke aanwijzingen. Bovendien kunnen sommige teksten en woorden (schijnbaar) tegenstrijdig zijn (Abram 1980,77-78).

Het is voor een mens onmogelijk en onverdraag$1 i j k$ alles te weten en te overzien, dat wil zeggen hetzelfde als God te zijn. "Die ganze und vollige Wahrheit war Gott tiberlassen. Der Mensch, selbst der schriftgelehrte oder der Weise, war eben nur Mensch und konnte daher auch nur Bruchsticke der wahrheit besitzen" (Petuchowski,1979,13), dat wil zeggen die delen die voor zijn leven en voor zijn situatie nodig zijn (zie ook Rosenzweig 1921,1976". 437).

"If, therefore, the statutes of the Torah could not be properly understood in the generation in which it was given, how much less could it be understood by later generations? In addition to this consideration, it was a fundamental doctrine of the rabbis that the Torah was given by God for all time, that it would never be exchanged for another Torah and certainly never rescinded, and that it provided for all possible circumstances which might arise at any time in the future. Nevertheless, in practice, changing conditions - social, economic, etc. - raised many new problems, as well as the question of their solution in accordance with the Torah. The new situations and spheres of human activity which arose, for which the written Law did not provide, could not be ignored. In 
fact, from the beginning the Written Law was the basis of authority of the oral Law for the future (Deut.17:8-11). It can thus be regarded as a historical fact that the Oral Law existed not merely from the moment the Written Law was given (and in this sense it is correct to say that the written and the oral Laws were given together to Moses at Sinai), but it may even be maintained that the oral Law anticipated the Written Law, as the Written Law not only assumes the observance of the oral Law in the future, but is in effect based on its previous existence. Since the written law relies - by allusion or by its silence - on statutes, customs, and basic laws explicitly mentioned in it (marriage, divorce, business), these statutes are ipso facto converted into a part of the Oral Law" (Enc.Jud., Vol.12,1440).

Het valt op, dat geschreven staat dat de openbaring van de Torah niet zomar eens op de een of andere dag plaatsvond, maar dat het op 'deze dag' (vandaag) gebeurde, zo leert een "midrasj' (uitleg). "On this day Israel came to mount sinai (Ex.XIX,11). Why on this day? Because, when thou learnest Torah, let not its commands seem old to thee, but regard them as though the Torah were given this day. Hence it says, 'On this day' and not 'on that day'". (Tanhuma B. Titro 38b, bij Montifore and Loewe $\left.1974,1978^{3}, 136-137\right)$.

De mondelinge Torah is iets anders dan een 'ongeschreven wet'. Ongeschreven wetten vinden hun oorsprong in natuurlijke levensprocessen. zij ontlenen hun zeggingskracht niet aan een goddelijke of menselijke instelling: met andere woorden de zogenaamde ongeschreven wetten zijn geen 'gegeven' wetten. Dit is met de schriftelijke en met de mondelinge Torah wel het geval (vgl.Urbach $1975,1979,291$ ).

De schriftelijke Torah kan zonder de mondelinge Torah niet verstaan worden, iets dat buiten het jodendom onvoldoende erkend wordt (vgl.Kaplan 1979,178-179). De joodse traditie 
kan alleen bestaan dankzij en door de interpretatie van de mondelinge Torah. "The written and Oral Law constitute together "two that are one" (Enc.Jud. Vol.12,1439). De schriftelijke Torah is de lering, de theorie zou men kunnen zeggen, terwijl de mondelinge Torah betrekking heeft op de praktijk. De mondelinge Torah kan niet buiten de schriftelijke, zegt Abram, "omdat er zonder schriftelijke Torah niets meer te interpreteren valt". Omgekeerd kan de schriftelijke Torah ook niet buiten de mondelinge bestaan, "omdat dat zou betekenen dat de schriftelijke Torah niet meer geinterpreteerd zou worden en haar betekenis voor de mensen als leidraad voor hun denken en handelen verloren zou hebben" (Abram 1980,77-78). De Talmoed zegt: "R. Johanan said: God made a covenant with Israel only for the sake of that which was transmitted orally, as it says, "For by the mouth of these words I have made a covenant with thee and with Israel" (Talm. Bab., Gittin 60b).

De wijze warop de schriftelijke en de mondelinge Torah met elkaar verbonden en in elkaar verstrengeld zijn, is uniek. Herr zegt in zijn artikel over de mondelinge Torah in de Encyclopaedia Judaica dit: "From the dogmatic point of view the oral Law has its basis in, and derives its validity from, explicit verses in the written Law, but at the same time the Written Law itself obtains its full validity and its authorlty for practical 'halakhah" from the oral Law $(\ldots)$. It is the oral Law itself which determines what the 'halakhah' of the Written Law is in practice" (Enc.Jud.,Vol. 12,1441; zie ook Deut.17:18-11).

De Torah - en dan bedoel ik hier uitdrukkelijk de schriftelijke én de mondelinge Torah - werd voor het jodendom tot een wetenschap over de levensweg die de mens behoort te gaan en daarmee tot een leerboek voor het gezonde leven. De Torah is bovendien een historisch boek. Het behoort tot de historie van de mensheid, maar het is ook een geschiedenisboek dat de joodse 
weg door het leven verhaalt.

3.3. Leven is leren, leren is leven.

$3 \cdot 3 \cdot 1$. De vertolking van de Torah.

Zoals hiervoor reeds opgemerkt, gaat de mondelinge traditie tot op Mozes terug. De Misjna zegt: "Mozes received the Torah at Sinai and transmitted it to Joshua, Joshua to the elders, and the elders to the Prophets, and the Prophets to the men of the Great synagogue" (Mishnah, fboth I, 1; zie ook Travers Herford $1945,1978^{2}, 19-22$ en Hertz 1945,12-15). Epstein tekent in de door hem geredigeerde engelstalige Talmoed-uitgave (Bab.Talm.) hierbij aan: "The transmission and reception were done orally. All evidence goes to show that there was a continous succession of "schools" headed by the Elders, prophets and, scribes of their respective generations, which maintained and developed the theoretical study and practical application of the Torah. The strength of the schools and their influence varied from time to time, but there is no reason for supposing that there was at any time an actual break in the continuity" (Bab.Talm. "Aboth I, 1, aant.3). Hoewel de vertolking van de Torah met het oog op het dagelijks leven bij Mozes begon (Goldman 1975,2), werd eerst langzamerhand het leren een integraal deel van het leven van het joodse volk. In eerste instantie leverden naast de meer op God betrokken profeten vooral de meer op de mensheid en de samenleving gerichte wijzen (geleerden, rabbijnen) een belangrijke bijdrage hiertoe. "De profeet is vol vuur, ijver en hartstocht; de wijze daarentegen was bezadigd, kalm en zelfs koel. De profeet is vol idealisme; de wijze is de realist die het leven beschouwt op een enigszins uti- 
litaire manier. De woorden van de profeet zijn die van de welsprekende prediker; de door de wijze gegeven raad is die van een verstandige leraar" (Epstein 1964,79;zie ook id.1959,1960. 73).

Het rabbijnse jodendom kent twee hoofdsoorten van schriftverklaring: de 'pesjat' (= de eenvoudige, de ongekunstelde) en de 'derasj" (= de zoekende, de onderzoekende).

De pesjat-vertolking legt een levensregel of een passage uit de Torah op letterlijke wijze uit. Als in de Talmoed gesproken wordt over "the plain meaning", zegt Mielziner, betreft dit deze direkte vorm van schriftuitleg (Mielziner $1968^{5}, 117-118$; zie Bab.Talm.,Hullin 6a).

De derasj-methode gaat volgens een meer verhalende en kunstzinnige wijze te werk. Ook is zij meer situatie-betrokken. Het resultaat van deze tweede methode noemt men 'midrasj' (Mielziner $1968^{5}, 117-118 ;$ zie ook Mishnah, Shekalim VI, 6: Petuchowski 1982,15-29). De pesjat-methode is erop gericht on de volle betekenis van de bijbelse teksten naar voren te halen. De derasj-methode is de meer persoonlijke vertolking, die iedereen kan toepassen, maar die toch vooral dgor de rabbijnen gebeurt (Kadushin $1952,1972^{3}, 11 ;$ id.,101).

Het is hier ook de plaats om iets meer te zeggen over de betekenis van het woord 'midrasj'. In de eerste plats heeft dit woord de betekenis van 'aktualiserende vertplking van de bijbel' (vlg.Zuidema $1977,1982,33$ en 285 ) volgens 6 de rabbijnse uitlegkunge (zie o.a. Strack $1976^{6}, 95-109$, Mielziner 1968, $\left.123-141\right)$. Voorts wordt het woord gebruikt voor de op schrift gestelde en geordende verzamelingen van 'midrasjiem" (meervoud van miarasj), zoals bijvoorbeeld de 'Midrasj Rabba, de 'Mekilta', de "Tanchoema". Alle verzamelingen tezamen voorzover bekend en, strikt genomen, ook nog niet afgesloten - zouden we 'de Midrasj' kunnen noemen (zie whitlau 1980).

De Midrass heeft "een didactisch karakter" 
(Van Praag 1978,19 ). Hij wil iets leren met betrekking tot het leven. "De midrasj is nooit alleen maar met een bijbeltekst bezig, maar verbindt de tekst altijd met de geleefde werkelijkheid. Hij belicht altijd én de tekst én een of meer facetten van de menselijke realiteit" (Van Uden 1981,40 ). Van Uden noemt deze 'tweepoligheid' een van de meest kenmerkende eigenschappen van de midrasj (id.,40).

De diskussies van de rabbijnen leveren niet één verklaring op, maar verschillende. Deze blijven, in de vorm van voor- en tegenwerpingen, naast elkaar staan. Zij behouden hun warde en in bepaalde situaties kunnen zij (weer) van belang zijn. De verschillende verklaringen vullen elkaar aan en doorlichten elkaar, ook al lijken zij elkaar soms tegen te spreken. Zo kunnen er "vele verbindingslijnen worden getrokken tussen de tekst en de situatie die allemal even 'juist" zijn" (id.,41).

De rabbijnse verklaringswijze heeft tot twee vormen of genres van "midrasjiem" geleid: een meer normatief en legalistisch genre dat 'halacha' heet en een meer vertellend genre dat '( $\mathrm{h}$ ) aggada' genoemd wordt.

Het woord 'halacha' betekent zoveel als: 'De weg die gegaan moet worden'. Met betrekking tot het menselijk handelen gaat het om de juiste levensweg, om de weg die de mens gaaf en gezond makt. 'De halacha' staat voor het geheel van bindende leef-en gedragsregels, dat het resultaat is van studie en diskusisie en zij heeft betrekking op alle facetten van het leven (zie Enc.Jud.,Vol.14,646). "The Halakah, as its meaning 'conduct' indicates. comprises life in all its manifestations religion, worship, law, economics, politics, ethics, and so forth. It gives us a picture of life in its totality and not of some of its fragments" (Ginzberg 1976, 166).

De halacha geeft ook bindende aanwijzingen met betrekking tot het gezonde bestaan, ziekte en genezen en voorts met betrekking tot allerlei 
sociale verhoudingen. Er bestaat ook een medische halacha (zie hoofdstuk 6). De halacha neemt tot op de dag van vandaag een centrale positie in de joodse traditie in. Een voorbeeld is de volgende regel: "It is a 'mitzvah' (= bindende, goddelijke opdracht) to visit those who are ill, to take an interest in their condition, and most important, to help them with whatever they may require. One who visits a patient and does not pray for his recovery has not properly fulfilled the 'mitsvah" " (Abraham 1980,135;vlg.Bleich 1981,4354). De hier weergegeven halachische gedragslijn 'bikkoer choliem' (bezoeken van zieken) is een regel van zeer oude datum. Hij wordt in de Talmoed genoemd (Bab.Talm., Sotah I4a).

Het woord 'aggada' is verwant met het Hebreeuws woord voor 'vertellen'. Een aggadisch verhal is een vertelling die "op de schrift betrokken is" of "met de schrift in verband gebracht wordt". Dit hoeft niet per se te betekenen "in verband met de bijbel". De aggada kan ook op andere geschriften betrekking hebben (Spicehandler 1980,253). De aggada is dus betrokken op de gehele Torah, op de schriftelijke en op de mondelinge. Zij vormt naast de halacha een eigen genre met eigen kenmerken: "The important consideration here is 'the telling', the narration, the wording, the style" (Enc.Jud. Vol.2,366). Op een vertellende wijze komen in de aggada de opvattingen, belevingen en houdingen van de rabbijnen aan de orde (Neusner 1979,11 ).

Halacha en aggada maken beide deel uit van de Torah-traditie. Tezamen zijn ze karakteristiek voor de literatuur van de joodse traditie. De halacha is meer aanwijzend, meer definitorisch-wetenschappelijk ook. zij geeft objektieve richtlijnen. De aggada cirkelt als het ware in subjektief-verhalende vorm om de halacha heen. Halacha en aggada horen bij elkaar. Er bestaat geen halacha zonder aggada en geen aggada zonder halacha, beide genres 
vormen samen het joodse weten. Bialik (18731934) drukte dit eens als volgt uit: "hallakhah is the crystallization, the highest quintessence of aggadah, while aggadah is the refinement of halakhah" (Enc.Jud.,Vol.2,354). Een voorbeeld van een aggadische midrasj is het in het voorwoord gegeven verhaal uit Leviticus Rabba XXX,2, de midrasj op Psalm 16,11 .

Tot het aggadische gedachtengoed behoren ook de legenden, sagen en mythen rond de verhalen en gebeurtenissen die in Tenach verteld zijn. Ginzberg verzamelde en rubriceerde veel van deze legenden in zijn 'Legends of the Jews' (Ginsberg 5727-5730/1967-1969).

Zoals gezegd, werd in de periode van de Tweede Tempel (538 v. Chr.-70 na Chr.) de Torah en het 'lerend voor het leven' omgaan met de Torah een integraal bestanddeel van het joodse leven. "Die Tora wird damit zum Buch der Lehre und der Forschung für das ganze Volk. Das Kind fängt an, in ihm zu lesen, mit ihm wird es erzogen, und es begleitet es sein ganzes Leben lang als objekt des Lernens und Forschens. In der Tora sind nicht nur die Weltschöpfung und das Schicksal des volkes und seiner vater in der Vergangenheit festgehalten, sondern sie enthalt auch eine Antwort für den Weg des Volkes und den Weg des einzelnen" (Safrai $1978,1980^{2}, 38 ; \mathrm{vg} 1$. id., 74-75).

$\mathrm{Na}$ de verwoesting van de Tweede Tempel en de verspreiding van de joden over de wereld bleef het 'lernen' de kern van het joodse leven. "Jewish national and religious life was in collapse. The outlook for Jewish survival was dark indeed. It was precisely at such a dire moment that the Jewish will to life and the undying spirit of Judaism gave new emphasis to the study of Torah as a substitute for the Temple sacrifices and as a means of worshipping God. True, the Temple on Mount zion was in ruins, the priesthood annihilated, the sacrificial system a thing of the past, but 
when the Jew sat down to study the sacred writings and to meditate on their oral interpretation, he was creating for himself a veritable sanctuary at which he became both ministering priest and communicant with God. He was performing a divine service at the new altar of Judalsm. It is in this connection that we must see the real significance of what Rabbi Yohanan ben zakkai did when he established the academy of Yavneh. Though Jerusalem had fallen, though the sacrificial system has terminated and thus no longer afforded a means of divine worship, he saved both the Jew and Judaism by founding a school for the study of Torah, which henceforth became the unifying symbol of Jewish nationhood. In this manner study became the substitute for the Temple service" (Goldman $1975,31-32)$. Zo is voor de joden de studie van de Torah "dem Wesenmerkmal seines Selbstverständnisses" geworden (Kremers, bij Veit 1983 . 98).

De ketting van de mondelinge traditie, "the sea of learning" (Grayzel 1968,216), had oorspronkelijk het karakter van een van mond tot oor doorgegeven overlevering. Het opschrijven van verklaringen en interpretaties was verboden. Rashi (Rabbi Solomon ben Isaac, 10401105) noteerde als kommentaar bij Exodus 34:37 ("en de Eeuwige zeide tot Mozes: schrijf u deze woorden op, want op den inhoud van deze woorden sluit Ik met $u$ een verbond en met Israë1"): "Deze woorden, en gij hebt geen verlof, om de mondelinge leer op te schrijven" (Onderwijzer,D1.II,5657-1897/1977,525). In de Talmoed staat: "The words which are written thou art not at liberty to say by heart, and the words transmitted orally thou art not at liberty to recite from writing" (Bab.Talm., Gittin 60b).

De geleerden, later rabbijnen genoemd, hadden het aanvankelijk ook niet nodig om de mondelinge Torah op te schrijven. Zij waren immers 
zelf geheel en al 'Torah'. Hun leven was leren en hun leren was leven. "The sages are men who learn so much Torah that they themselves become Torahs. What they do is Torah. They are people who do things natura IIy in the way in which the Torah, given by God, wants to do things" (Neusner 1980,13). Bovendien was er van de verstrooisng van de gemeenschap aanvankelijk nog geen sprake.

op een gegeven moment werd het toch toegestaan van de mondelinge leringen en verhalen persoonlijke aantekeningen te maken. Het aantal regels nam voortdurend toe. Bovendien was sinds de verwoesting van Jeruzalem (70) het belangrijkste geestelijk centrum langzamerhand verschoven en in Babylonië komen te liggen. ook makkten de rabbijnen schriftelijke aantekeningen om het besprokene nauwkeuriger te kunnen doorgeven (Safrai 1978,1980,136; Kaplan 1979,185-186). Omdat men vergeten nog erger vond dan het op schrift stellen ervan, begonnen de rabbijnen toen met het schriftelijk vastleggen van de mondelinge Torah (zie strack $1887,1976,9-16$; Abram $1980,78-80)$. Zo ontstonden de 'Misjna', de 'Talmoed' en vele andere geschriften en kommentaren, onder andere de Midrasj-verzamelingen.

De Misjna (= herhaling, leer), de eerste kodifikatie van de mondelinge Torah, is gevormd uit studiemateriaal van de rabbijnen. Het werd in de Misjna in een groot aantal halachische regels vastgelegd. De eindredakteur van wat nu bekend is als 'de Misjna' was rabbi Jehoeda ha-Nasi (ca.135-217). (zie o.a. Neusner 1978). Hiernaast ontstond nog de 'Tosefta' ( ging, aanvuliing), terwijl ander materiaal dat geen plats in de misjna vond onder de naam 'Baraita' (= er buiten staand) bewaard bleef. "De Talmoed moet men zich voorstellen als een verzameling kommentaren, verslagen, aanvullingen en opmerkingen bij de Misjna", zegt Musaph-Andriesse (Musaph-Andriesse 1973,45). Palache vermeldt dat de Talmoed niet zozeer 
een kommentaar op de Misjna bevat alswel de verslagen van de besprekingen en de debatten der wetgeleerden nazar aanleiding van de Misjna (Palache $\left.1922,1980^{3}, 89\right)$. Zo moet men zich de Talmoed dan ook voorstellen: niet als een wetboek, maar als een verzameling van protokollen van diskussies en interpretatiles van de rabbijnen. (zie stemberger 1982). Maar: "The Talmoed is not merely an anthology of this and that. It is a set of carefully worked out discussions, with a plan and a goal" (Neusner 1979,13). Evenals de Torah is ook de Talmoed een leerboek voor 'leven'. "The Talmoed teaches us how to analyze what we do and what we are" $(i d ., 1)$.

Als van de Talmoed gesproken wordt, bedoelt men de zogenaamde Babylonische Talmoed, de Talmoed Bavli. Hiernaast bestaat nog de minder gebruikte Talmoed Jerusjalmi. De Talmoed werd in de zesde eeuw afgesloten. Haar belang is dat $z i j$ de neerslag is van de mondelinge joodse traditie die altija de basis is geweest van het joodse leven door de eeuwen heen (Berkovits 1980,4 ; Palache $\left.1922,1980^{3}, 142\right)$. De Talmoed staat zó centraal in het jodendom, dat er soms de gehele mondelinge Torah mee bedoeld wordt.

De verzamelingen van Misjna, Talmoed en de verdere literatuur werden op den duur zo omvangrijk, at er een behoefte ontstond aan meer systematische samenvattingen. Als gevolg hiervan ontstonden in de Middeleeuwen de diverse zogenaamde 'codices'. In deze codices was het onderscheid tussen de filosofischjoodse wijze van denken en de rabbijnse praktisch verdwenen. Eerst in de vorlge eeuw kwam onder invloed van de verlichting het onderscheld tussen een meer aan de Grieks-westerse wijze van weten gebonden vormgeving van het joodse weter en de rabbijnse lering als vorm van weten weer naar voren. Andere vormen, zoals de strikt literaire, de zionistische en de meer mystieke literatuur van kabbala en chassidisme laat ik in deze studie buiten beschou- 
wing (zie 0.a. Zwi Werblowsky 1980, 217-223; Scholem $1970,1976^{2}$; Weiner $1969,1979^{5}$; Buber 1927 ; id.,1967,1978 ; id.,1968).

Leren om te leven en de betekenis van het leerhuis.

Het centrum van het dagelijkse leven en van de ordening van het leven rond (de studie van) de Torah heeft het jodendom als traditie doen leven, doen voortleven en doen overleven. Het is een wijze van leven die tot op de dag van vandaag doorgaat. Er wordt zoveel warde aan ontleend, dat juist hierin de bestemming van het leven en van het mens zijn ligt (Aschkenasy 1978,140). De studie van de Torah leidt ertoe, dat de mens antropologisch-gezondheidskundig zich als gezond en gaaf weet te ervaren (vlg. Abram 1980,219$)$. Zij leidt voorts tot het bereiken van 'morele perfektie' in de omgang met en de verantwoordelijkheid voor de aqder (Goldman 1975,44-47; vlg.Levinas 1969,1971 ${ }^{2}$ ). The Misjna leert: "Great is Torah for it gives life, unto those that practise it, in this world and in the world to come, as it is said: for they (the subjects in all cases is - Words of - Wisdom, which is identified with Torah Epstein) are life unto those that find them, and health to all their flesh (Prov.IV,22) and it says (a1so): it shall be health to thy navel, and marrow to thy bones (Prov.III, 8 ), and it says (also): she is a tree of life to them that lay hold upon her, and happy is everyone that holdeth her fast (Prov.III,18), and it says (also): for thy shall be a chapter of grace unto thy head, and chains about thy neck (Prov.I,9), and it says (also): she will give to thy head a chaplet of grace; a crown of glory will she bestow on thee (Prov.IV,9; some versions insert here ibid.IX,11), and it says (also): length of days is in her right hand; in her left hand are riches and honour 
(Prov.III,16), and it says (also) for lenght of days and years of life, and peace, will they add to thee (Prov.III, 2)" (Mishnah, Aboth VI, 7).

Eerder in dit hoofdstuk merkte ik al op dat de Torah voor de jood "alles' is. De Torah draagt het mens zijn en geeft richting aan het leven. Dit betekent wel dat men $\mathrm{zich}$ in de Torah moet verdiepen en dat men de woorden van de Torah door zich heen moet laten gaan. "De Torah wacht op dragers" (Haggada 5731,5743 3 ,4). Studie van de Torah - 'Talmud Torah' in het Hebreeuws - is een bezigheld van de allerhoogste orde (Enc.Jud.,Vol.15,453-460), een bezigheid, die door haar te verrichten, dat wil zeggen te (be)leven, de mens in zijn mena zijn bevestigt. De rabbijnen spreken over een bezigheid die onophoudelijk vreugde schenkt (Kadushin 1938,43 ; Schechter $\left.1909,1975^{5}, 148-169\right)$. Kennis van de Torah is voor hen een "godsgeschenk" (id.,47). Emmanuel Levinas spreekt van "een bijzonder soort intellectueel leven" (Levinas $\left.1969,1971^{2}, 80\right)$. "The Torah is there for us to study and to master" (Neusner 1980,77). De Torah is het grootste van alles en het lexen kennen van de Torah is het hoogste dat bereikbaar is (Mishnah, Aboth VI,6).

In de Talmoed wordt gezegd: "R. Sammuel b. Nahmani expounded: with reference to the scriptural text, 'Loving hind and a graceful roe' etc. (Prov.V,19), why were the words of the Torah compared to a 'hind'? To tell you that as the hind has a narrow womb and is loved by its mate at all times as at the first hour of their meeting, so it is with the words of the Torah. They are loved by those who study them at all times as at the hour when they first made their acquaintance. 'And a graceful roe'? Because the Torah bestows grace upon those who study it. 'Her breasts will satisfy thee at all times' (Prov.v,19). Why were the words of the Torah compared to a breast? As with a breast, however often the 
child sucks (lit. 'feels', 'searches') it so often does he find milk in it, so it is with the words of the Torah. As often a man studies them so often does he find relish in them" (Bab.Talm. Erubin 54b).

Studeren is in de joodse traditie een gebeuren dat geen mat kent (Mishnah, Peah $I, 1$ ). Leren is van het grootste belang. Zonder studie kan men niet (geestelijk gezond) leven. Scheepstra: "Het onderwijs wordt als niet minder dan een bestaansvoorwaarde beschouwd: een stad waarin geen onderwijs gegeven wordt, gaat ten onder; ook de verwoesting van Jeruzalem wordt toegeschreven aan het verwaarlozen van het onderwijs aan de kinderen" (Scheepstra 1983,8; zie ook Bab.Talm. Shabbath 119b). Kenmerkend voor de joodse traditie is, dat $z i j$ een nooit ophoudende diskussie kent tussen de leerling en de leraar, met als doel te onderzoeken wat de inhoud en de betekenis van de woorden van de Torah zijn én te onderzoeken hoe in het dagelijkse leven ermee geleefd behoort te worden.

De studie van de Torah is geen in zichzelf genoegzame bezigheid. "De leerling die de Torah bestudeert, probeert aanwijzingen te vinden die zi in doen en laten nu richting kunnen geven. Oplossingen voor problemen zoekt hij in reeds bestaande teksten en in de schriftelijke en mondelinge kommentaren op die teksten" (Abram 1980,81). Bestudering van de Torah, van het joodse weten (theorie), en het leven (praxis), zijn nauw met elkaar verbonden. "Rabbi Ishmael says: if one studies in order to teach, it is granted him to study and to teach; but if one studies in order to practice, it is granted him to study, to teach and to practice" (ARN III, 27).

De vraag naar wat het belangrijkste is, bezig zijn met de 'theorie' of in de praktijk van het leven staan, heeft in het jodendom eens deze diskussie opgeleverd: "R. Tarfon and the Elders were once reclining in the upper storey 
of Nithza's house, in Lydda, when this question was raised before them: Is study greater, or practice? R.Tarfon answered, saying: Practice is greater. R. Akiba answered, saying: Stuay is greater, for it leads to practice. Then they all answered and said: Study is greater, for it leads to action" (Bab.Talm., Kidaushin 40b). En de Misjna zegt: "Study is not the most important thing, but deed" (Mishnah, Aboth I, 17).

Het is war dat in het jodendom een grote nadruk ligt op het doen. Heschel noemt het jodendom "a science of deeds". Hij merkt hierbij op dat de westerse filosofie vraagt naar "what is being? What does it mean to be?". De joodse traditie vraagt "what is doing? What does it mean to do?" (Heschel 1955,1976²,285). De aanzet hiervoor wordt gegeven in Exodus 24:7, war staat: "Alles, was ER geredet hat, wir tuns, wir hörens!" (Namen 24, 7). Het handelen naar de Torah staat voorop: "It is in deeds that man becomes aware of what his life really is $(. .$.$) . It is in the employment of his will.$ not in reflection, that he meets his own self as it is: not as he should like it to be. (...). The heart is revealed in the deeds. The deed is the test, the trial and the risk" (Heschel $1955,1976^{3}, 284$ ).

Het jodendom waarschuwt overigens voor een al te idealistisch bezig zijn met (de studie van) de Torah (vgl.Friedlander 1981,87). Dat studie van de Torah een bezigheid van de hoogste orde is en dat van haar gezegd wordt dat zij geen mat kent, wil nog niet zeggen dat het goed is als men zich uitsluitend hiermee bezighoudt. De traditie leert: "Rabban Gamaliel the son of R. Judah the Patriarch said: excellent is the study of the Torah together with a worldiy occupation, for the energy (taken up) by both of them keeps sin out of one's mind; and (as for) all (study of the) Torah there is no worldly occupation, the end thereof (is that) it comes, to nought and brings sin in its 
train" (Mishnah,Aboth II, 2). De Talmoed zegt ook: "He who does not teach his son a craft, teaches him brigandage" (Bab.Talm.,Kiddushin 29a). En R.Huna zei eens: "He who only occupies himself with the study of the Torah is as if he had no God, for it is said: 'Now for long seasons Israel was without the true God' (II Chron.XV, 3). What is meant by "without the true God?' - It means that he who only occupies himself with the study of the Torah is as if he had no God" (Bab.Talm. "Abodah Zarah $17 \mathrm{~b})$.

De joodse traditie vraagt dus niet van de mens om alleen maar met de studie van de Torah bezig te zijn, maar wel dat men er 'permanent' mee bezig is (Abram 1980,22-24;id.,117-119). "Iedereen wordt geacht zijn hele leven te leren. Iedereen wordt geacht een permanente leerling te zijn. Bij permanent leren gaat het om een dagelijkse bezigheid, die dikwijls moeilijk op te brengen is. De leerling kan zich de gewoonte van het permanent leren alleen maar dan eigen maken als de kennis waar hij naar streeft, voor hem persoonlijk van belang is. Permanent leren gaat niet vanzelf. Leren vereist kracht, permanent leren vereist dat permanent" (Abram 1983,13).

In zijn dissertatie heeft Abram vijf studieregels uitgewerkt die het permanent leren praktisch gestalte moeten geven. Ik vat deze hier interpreterend samen:

1. Leer permanent, dat wil zeggen: leer steeds weer:

- stel niet uit: 'zeg niet: als ik tijd heb, zal ik leren. Misschien zul je nooit tijd hebben" (Mishnah, Aboth II, 4);

- leer op vaste tijden: 'Shammai zegt: reserveer een vaste tijd voor je studie van de Torah' (Mishnah, Aboth I, 15);

- probeer elke dag te leren: "If you forsake the Torah for one day, the Torah will forsake you for two days" (Jer.Ta1., bij Goldman 1975,56;zie Mishnah, Aboth I, 
15 en Bab.Talm. Abodah Zarah 19b).

2. Herhaal, want dit is het fundament van het leren. Het weten dat $z i j n$ warde behoudt spreekt steeds weer aan. "There is a story about a learned man who came to see the Kotzker. No longer young - he was close to thirty - the visitor had never before been to a rebbe. "What have you done all your life?' the master asked him. "I have gone through the whole Talmud three times', answered the guest. 'Yes, but how much of the Talmud has gone through you?" Reb Mendl inquired" (Heschel 1973,1977²,107;zie Mishnah, Aboth V, 12).

3. Leer individueel en kollektief. Leren is een persoonlijke daad. Het is lets dat de leerling zelf moet doen, maar warbij hij anderen nodig heeft. "Just as fire cannot ignite by itself, so the words of the Torah cannot endure with him who studies alone" (Bab.Talm. Ta'anith 7a). En: 'Wanneer tien personen te zamen zitten en zich met de Torah bezighouden, dan rust de shekinah (= Goddelijke Aanwezigheid) op hen" (Mishnah, Aboth III, 6).

4. Leer door in de praktijk brengen. "Torah heeft niet alleen betrekking op leren en onderwijzen, maar ook op gedrag. Leren behoort in praktisch handelen uit te monden (...). De Torah is niet alleen mar een leer, maar ook een manier van leven' (zie Mishnah, Aboth $V, 14)$.

5. Plan het elgen leren. 'De basis van het permanente leren is niet het instituut 'school' maar de individuele leerling die zijn leven zo plande, dat het leren er een vaste plats in kreeg'. 'De permanente leerling die het eigen leren plant, beinvloedt zijn omgeving door:

- van elke leefomgeving (-situatie) ook een leeromgeving (-situatie) te maken,

- aan veelsoortige vormen van individueel en kollectief leren deel te nemen of die te stimuleren, 
- te ijveren voor het stichten en in stand houden van scholen en leerhuizen en voor het toevoegen van leerkernen (studiegroepen, studiecentra) aan vrijwel elke organisatiel' (Abram 1980,151-217).

Van oudsher ging men voor schriftonderzoek en voor het toetsen van de levensvragen aan de leer bilj elkaar zitten. Zo ontstond de naam 'yesjiva', die letterlijk 'zittend' betekent, als een plaats van studie (Enc.Jud.,Vol.2,199200). Momenteel is een yesjiva meestal een hogere talmoed-akademie. Een andere naam voor een dergelijke 'plats van studie' was: 'huis van studie', in het Hebreeuws "bet ha-Midrasj" (leerhuis).

Het is met name dit bet ha-Midrasj dat verbonden is met de studie van de Torah. Het kreeg een kreatieve funktie in het leven van de mensen (Kadushin 1938,61). "Het Beth ha Midrasj was open voor allen, geleerde en gewone mensen; $(\ldots)$. Het was ook de plats waar men zijn problemen heen bracht, levenskwesties en vragen van alle dag: het leven werd aan de Leer, de Leer aan het leven getoetst" (Wolff 1979,362). En Goldman schrijft met betrekking tot het leerhuis: "Even as the desert is open to all and is not privately possesed, so is the Torah accessible to all. and the private property of none (Mekilta, Vol. II, 198)" (Goldman 1975,50).

De verschillende scholen behandelden niet altijd en niet bij voorbat dezelfde leerstof. Iedere school maakte bepaalde keuzes. Bovendien gaven de rabbijnen en scholen aan dezelfde teksten soms een verschillende uitleg of nadruk.

Over het precieze ontstaan van de leerhuizen als een levende kracht in het jodendom weten we zo goed als niets (Glatzer 1937, 19812,124; Goldman 1975,23; Scheepstra 1983,16-19). Volgens Goldman traceert de rabbijnse traditie het bestaan van de leerhuizen tot in de tijd 
van de profeten en zelfs van de artsvaders. "To the Jewish sages, Jacob is the exemplar of love of learning, and they interpret the words of the Bible. "and Jacob was a quiet man, dwe11ing in tents' (Gen.25:27), as meaning that Jacob's abode was a house of study (Midrash Rabbah,Gen.R.LXIII, 10)" (Goldman 1975, 23).

Het woord bet ha-midrasj treffen we voor het eerst expliciet aan bij sirach (Jesus ben sira) in het begin van de tweede eeuw vón onze jaartelling. "Komt naar mij toe onwetenden en neemt uw intrek in het leerhuis" (Sirach 51:23). Volgens Boertien betreft het hier een verwijzing naar Deuteronomium 30:11-14 (Boertien 1974,11).

Een nauwkeuriger voorstelling van een leerhuis krijgen we eerst als R. Jochanan ben Zakkai en na hem Gamaliël (zie Enc.Jud.,Vol.7,296-297) het hiervoor al genoemde leerzuis in Javne oprichten (Glatzer 1937,1981',124; vgl.Bab. Talm. Gittin 56b). Dit leerhuis kan men als het prototype opvatten van de latere leerhuizen in het toenmalige Palestina, in Babylonië en, nog weer later, in Europa. In de Middeleeuwen onderkende onder andere Maimonides het belang van het leerhuls voor de joodse traditie. Hij achtte het leerhuis belangrijker dan de synagoge. "The House of study is greater than the House of Worship" (Maimonides, bilj Goldman 1975,150; zie Bab.Talm., Meglilah 27a). Goldman vermeldt dat ook later, met name in oost-Europa, de leerhuizen een belangrijke funktle in het joodse gemeenschapsleven zijn blijuen vervulien.

In onze eeuw kreeg het leerhuis een nileuwe impuls door het werk van Franz Rosenzweig (zie hoofdstuk 2). Door de oorlog stokte deze ontwikkeling. Maar in de vijftiger jaren opende Goldschmitt in de geest van Rosenzweig een leerhuis in zurich (Goldschmitt 1960). En in de vijftiger jaren ontmoetten ook in Amsterdam een aantal joden en niet-joden elkaar om het konsept van een leerhuis in die stad uit te 
werken, een leerhuis war zowel joden als niet-joden zich met de studie van de Torah zouden kunnen bezighouden. Dit is het begin geworden van het voor Nederland specifieke leerhuiswerk van joden en niet-joden (zie Abram e.a. 1983).

Uit het voorgaande blijkt dat de studie van Torah en Talmoed niet op basis van "hoorcolleges" geschiedt. Torah-studie is een bezigheid die individueel en in kleine groepen plaatsvindt onder begeleiding van een leraar die zelf meeleert. "Provide thyself with a teacher and get thee a fellow-disciple" (Mish$n a h, A b o t h \quad I, 6)$. Om in het begin niet al te zeer in verwarring te raken, kan men het beste met één leraar beginnen, zegt de Talmoed (Bab.Talm., Abodah Zarah 19a-b). Leraar en leerling zijn in de eerste plaats lerenden die elkaar helpen, merkt Abram op. Pas in de tweede plaats komt het onderwijzen dat het leren moet bevorderen (Abram 1980,272). Het samen leren van leerling en leraar houdt in dat de leraar ook leerling is en de leerling ook leraar (vgl.Rosenzweig 1937,101$)$. Een leerling kan niet zonder leraar, en een leraar is geen leraar zonder leerlingen. $\mathrm{Er}$ is een Talmoedtekst die zegt: "I have learned much from my teachers, and from my colleagues more than from my teachers, but from my disciples more than from all" (Bab.Talm. Ta'anith 7a).

Abram karakteriseert de relatie van leraar en leerling als een relatie van "sympathisch partnerschap" (Abram 1980,249). Hij wil hiermee niet alleen aangeven dat de joodse traditie leraar en leerling ziet als partners in de studie en de toepassing van de Torah, maar ook dat deze relatie de dimensie heeft van partners die vertrouwen in elkaar hebben, elkaar respekteren en elkaar toegenegen zijn (id., 248). "R. Eleazer (b.Shammua) said: Let the honour of thy disciple be as dear to thee (as thine own and) as the honour of thy companion, and the honour of thy companion as the fear of 
thy teacher, and the fear of thy teacher as the fear of Heaven" (Mishnah, Aboth IV,12). De relatie tussen leraar en leerling, zoals de Torah die ziet, zegt Abram verder, "is ook te begrijpen als een persoonlijke gespreksrelatie, als een gesprek onder vier ogen, als een spreken van-aangezicht-tot-aangezicht" (Abram $1980,252)$.

De leraar neemt in de joodse traditie een belangrijke plaats in (Neusner 1980,13). De autoriteit van de leraar heeft de autoriteit van de vader verdrongen (vgl. Fromm 1975,58). In de Misjna staat een belangrijke aanwijzing: "(If a man went to seek) his own lost property and that of his father, his own has first place; if his own and that of his teacher, his own has first place; if that of his father and that of his teacher, his teacher's has first place - for his father did but bring him into this world, but his teacher taught him wisdom brings him into the world to come; but if his father was also a Sage (variant: 'equal, in wisdom to his teacher'), his father's has first place. If his father and his teacher each bore a burden, he must first relieve his teacher and afterward relieve his father. If his father and his teacher were each taken captive, he must first ransom his teacher and afterward ransom his father; but if his father was also a sage he must first ransom his father and afterward ransom his teacher" (Mishnah, Baba Metzia II, 11).

De relatie van leraar en leerling houdt niet in. dat deze betrekking symmetrisch is. De relatie is "asymmetrisch met symmetrische momenten" (Abram 1980,250). De leraar weet nu eenmal meer, zowel inhoudelijk als didaktisch. Van de leraar mag verwacht worden dat hil "goed nar de leerling weet te luisteren en zelfs de vragen weet te raden die de leerling niet stelt, terwijl de sympathie van de leraar voor de leerling èn de Torah hem in stat stelt de vragen van de leerling te 
beantwoorden" (id.,249-250). De relatie is niet volledig wederkerig, stelt Abram. "De leraar moet zich in de leerling kunnen verplaatsen, terwijl de leerling zich niet in de leraar hoeft te verplaatsen (...). De leraar moet zijn eigen situatie en die van de leerling kunnen omvatten; de leerling heeft zijn handen vol aan zichzelf" (id.,251).

In de leersituatie heeft elke leerling zijn eigen leerweg te gaan (Abram 1980,225,261; vgl.op 't Root,1979). "Niet de leraar 'objektiveert' de Torah, mar het leren van de leerling doet dat" (Abram 1980,255). "Het is het spreken en het gesprokene, of met ander woorden: de Torah, dat (die) de leerling onderricht" " zegt Abram in navolging van Levinas (id.,253). En voorts: "De Torah aanvarden is niet het einde, mar juist het begin van het gesprek tussen leraar en leerling" (id.,255).

In de hulpverleningssituatie wordt primair de klacht of vraag die uitgesproken wordt, tot begin van het gesprek genomen. In het leerhuis - de situatie waarin leraar en leerling samen 'leren' - staat veelal een tekst centraal die aan de vragen van leraar en leerling gerelateerd wordt, maar het kan ook omgekeerd. De interpretaties en kommentaren van de geleerden en rabbijnen worden erbij betrokken en, gerelateerd aan de eigen situatie en vragen, bestudeerd.

Dok hier gaat het erom de Torah niet te gebruiken voor eigen belangen. Het gaat erom in alle oprechtheid het zelfstandig denken en handelen van de leerling te bevorderen. "Het beoogde leerresultaat, de gaafheid, kan hem (de leerling) in de volle betekenis met alle persoonlijke konsekwenties voor hemzelf pas duidelijk worden tijdens het leerproces, tijdens het belangeloze leren, het leren 'li-sjema'" (Abram 1980,225). Het leren 'li-sjema' is het leren om het leren zelf en dit leren staat het hoogst aangeschreven (id.,225). Dit leren 
brengt "leven" en het valt samen met gaaf, gezond mens zijn. De Talmoed zegt: "Whosoever occupies himself with the Torah for its own sake his learning becomes an elixer of life to him, for it is said, 'It is a tree of life to them that grasp it' (Prov.III,18), and it is further sald, 'It shall be as health to thy navel" (Prov.III, 8); and it is also said, 'For whoso findeth me findeth life'(Prov.VIII, 35 ). But, whosoever occuples himself with the Torah not for its own sake, it becomes to him a deadly poison" (Bab.Talm.,Ta'anith 7a). Abram: "De weg die tot het belangeloze leren voert is het permanente leren en dit is dan ook precies de reden om permanent te leren: permanent leren, dat eerst niet belangeloos is, gaat uiteindelijk juist door de permanentie van het leren over in een leren, dat wèl belangeloos is" (Abram 1980,226). In dit permanente leren is "het onderscheid tussen leren als doel en als midal opgeheven" en Abram noemt zo"n leerling een "vrij mens" (id.,227).

De Talmoed zegt over permanent leren, dat men de woorden van de traditie nlet vaak genoeg kan horen. Zelfs Aaron leerde vier keer. "Aaron who learned from Moses who had it from the Omnipotent had to learn his lesson four times how much more so an ordinary pupil who learns from an ordinary teacher" (Bab.Talm., Erubin 54b).

Men kan de woorden van de Torah niet vak genoeg horen, zij zijn telkens weer nieuw en aktueel. De woorden van de Torah zijn woorden die dichtbij de mensen staan. zij zijn niet in de hemel, noch achter de zee, zegt de Talmoed. De rabbijnen leggen dan uit dat de woorden van de Torah niet bij de machthebbers gevonden worden, noch bij degenen die trots en arrogant zijn, noch bij degenen die op expansie uit zijn (Bab.Talm., id.,55a).

voor de jood is het leren de essentle van het menseliyk bestaan (zie Neusner 1980,13). Dok het nieuwe leren van onze tijd is niets anders 
dan een variant van het aloude "leren": "Het is het samen leren en het elkaar onderwijzen, het is het partnerschap tussen de leerlingen onderling en tussen de leraar en de leerling, het is coöperatief en niet competitief, het is zowel individuele inspanning als sociaal gebeuren, het is de essentie van de joodse kultuur" (Abram 1980,269). De jood die leert streeft ernaar een 'whole jew' te zijn en daarmee een in alle opzichten gaaf c.q. gezond mens. "studying $\operatorname{Torah}(\ldots)$ means a new way of being a person (...). Studying Torah is a new way of living" (Neusner 1980,45). Het leren geeft 'leven' aan het leven. Abram spreekt de hoop uit dat de wereld niet een school mar een leerhuis is en het leven niet een permanente school maar wel een permanent leerproces (Abram 1980,270).

Permanent leren houdt in dat men voortdurend verandert. Voortdurend veranderen wil zeggen dat de mens steeds in beweging is. Alleen wat levend en gezond is, is in beweging! ook het omgekeerde gaat op. Leven is in het Hebreeuws 'chaj'. Hiervan is 'chajiem' afgeleid, dat 'Leven', 'de levenden' betekent.

Als er niet geleerd wordt en er geen leerhuizen zijn, is er geen joods leven mogelijk. En als er geen joods leven is, is de mens de Torah kwijt en daarmee de aanwijzingen ten leven van dit intrinsieke weten omtrent mens zijn en leven. Een "midrasj": "If there will be no little children, there will be no pupils; if there will be no pupils, there will be no scholars; if there will be no scholars, there will be no Torah-study; if there will be no Torah-study, there will be neither synagogues nor houses of study. If there are no synagogues and houses of study, the Holy One, blessed be He, will not permit His 'Shechinah' to abide in the world" (Midrash Rabbah,Lev.R. $X I, 7)$. 
Enkele aantekeningen.

De filosofisch-joodse auteur Emmanuel Levinas heeft eens de vraag gesteld hoe men nar Israels stem moet luisteren. Het antwoord erop is van het grootste belang, omdat, zo zegt Levinas, over het algemeen aangenomen wordt, dat het jodendom en daarmee ook zijn filosofische antropologie een achterhaalde zaak is en dat zijn konsepten opgenomen zijn in de grotere synthesen van de westerse kultuur. Bovendien, zo zegt Levinas, lijken in vergelijking met de warden van andere godsdiensten, de waarden van het jodendom niet veel meer dan gestamel. In het gunstigste geval zlet men de stem van Israël als de stem van een voorloper.

Levinas wijst er dan op dat, als men zich met de bijbelse warden bezighoudt, men deze niet los mag zien van hun bronnen. De bijbel ( $\mathrm{Te}-$ nach) staat niet op zichzelf, mar zij makt deel uit van "een specifiek joodse fysionomie: (...) de mondelinge traditie van de exegeten, die zich heeft gekristalliseerd in de Talmoed en zijn kommentaren. De manier die door deze traditie is ontwikkeld, is het rabbijnse jodendom" (Levinas 1969,1971 238 ).

Als het erom gaat het jodendom te leren kennen, moeten we ons wenden tot het rabbijnse jodendom. "Voorzover het jodendom een historische werkelijkheid is - d.w.z. het jodendom zonder meer - is het rabbijns" (id.,38).

Het is ait rabbijnse jodendom, uitgekristalliseera in de literatuur van de schriftelijke en mondelinge Torah, dat een belangrijk kleinood voor die mens blijkt te zijn die zich de vraag naar 'leven" stelt. 'Leven' moeten we hier in zijn existentieel-antropologische kontekst verstaan. De (studie van de) Torah geeft leven aan degenen die er zich mee bezig houden, tot in de lengte van jaren.

De joodse traditie is niet zozeer een traditie die starre regels en leerstellingen (theo- 
rieën) kent, die gehoorzaamd moeten worden, mar een traditie die voortleeft, omat er telkens weer mee ingestemd wordt. Met behoud van de grootst mogelijke persoonlijke vrijheid, geeft juist dit feit gezag en autoriteit aan de traditie. De essentiele vraag voor een leerling, zegt Abram, is niet: "Waarom zal ik gehoorzamen?, maar "waarom zal ik instemmen?" (Abram 1980,29).

Een traditie die telkens weer persoonlijk been geleefd en weer in woord en geschrift verwerkt wordt, zoals de joodse traditie, loopt niet het gevaar "ouderwets, versteend, wit de tijd, een dode letter, konformistisch, konservatief en doods" te worden. Traditie is in het jodendom "geen statisch, maar een dynamisch gegeven, waarin de kreativiteit van het gehele volk zich in de loop van de tijden heeft uitgedrukt en nog uitarukt" (Zuidema 1977,1982, , 156).

Het joodse weten is "de neerslag van de ervaringen die het volk heeft opgedaan in een eeuwenlange geschiedenis. Het spectrum van deze ervaringen is zeer breed. zij omvatten die van de omgang met God, met elkaar als gemeenschap, maar ook met een vijandig gezinde buitenwereld. Deze ervaringen moeten in elk geslacht opnieuw getoetst worden. Dat wil zeggen dat van de enkeling gevraagd wordt of hij, in zijn specifieke levenssituatie, zich er in kan herkennen, of hij, met de hulp ervan, kan komen tot een zingeving van zijn leven. Traditie is dus noolt een koel en objektief gegeven, maar kan alleen maar funktioneren in een zeer persoonlijke relatie. $(\ldots)$. Dat betekent dat de enkeling door een zeer persoonlijke beslissing, die niemand anders voor hem kan nemen, zich in het traditieproces inschakelt. Hij is zich ervan bewust in een geschiedenis te staan, die vóór hem geweest is, en die ook na hem verder zal gaan. $\mathrm{Hij}$ is het die in zijn persoon het verleden met de toekomst verbindt. Dit is zijn persoonlijke verantwoordelijkheid. De traditie biedt 
hem de ervaringen aan van de gemeenschap en van de mensen die hem voorgingen, mar het is an hem die ervaringen te toetsen aan zijn eigen levenssituatie, ze te onderzoeken op hun leefbaarheid. Maar dat is niet iets dat $\mathrm{zich}$ in volstrekte afzondering voltrekt. Hij stat niet alleen. Hij makt deel uit van een gemeenschap, warmee hij zich verbonden kan voelen omat zij staan voor eenzelffie verantwoordelijkheid" (zuidema $1977,19824,156-157$ ). De jood is door zijn jood zijn verbonden met de gemeenschap van de joodse traditie. Traditie wil in het jodendom zeggen dat het verleden bewaard, herdacht en getoetst wordt met het oog op heden en toekomst. Het is een doorvertellen dat niet ophoudt.

Een laatste aantekening nog. De in 3.3 .2 besproken karakteristieken van de betrekking tussen en de verbondenheid van leraar en leerling gaan mijns inziens ook in veel hulpverleningssituaties op. Ook hier is er sprake van een persoonlijke gespreksrelatie, van een gesprek onder vier ogen. "van-aangezicht-totaangezicht". Zo gaat het in de andragogische hulpverleningssituatie erom de ander "bij te staan". Dit moet, zo zegt Warmenhoven, zoletterlijk mogelijk worden opgevat en hij vervolgt: "Nader uitgedrukt, het gat om het daadwerkelijk respekt voor het leven van deze andere mens, die tot hiertoe gekomen niet langer alleen kan, wil of durft te zijn met dit, zijn bestaan. De mogelijke strekking van de 'bijstand' is in het zojuist gestelde mede gegeven. Het gaat om bijstand terzake van dit leven, terzake van dit al of niet duidelijke, dit al of nilet als leefbaar bevgnden levensontwerp" (Warmenhoven $1973,1983^{2}, 62$ ). In de (huisarts)geneeskunde is het hier verwoorde eveneens en zelfs op het meest basale nivo aan de orde.

Iedere mens heeft zijn eigen leven te leiden. Het daadwerkelijk respekt voor het leven van de ander kan alleen gerealiseerd worden als er 
sprake is van een "belangeloze toewgnding" tot die ander (Warmenhoven 1973,19832, 55). "De grond van de toewending is geen andere, kan geen andere geacht worden te zijn dan de van die ander uitgegane vraag" (id.,63). 
HOOFDSTUK 4: GEZONDHEID EN GENEZEN IN DE

JOODSE TRADITIE: EEN VERKENNING.

$4 \cdot 1$. Inleiding.

De Encyclopaedia Judaica gaat met betrekking tot de geneeskunde uit van een historisch overzicht dat uit vier grote perioden bestaat. Het eerste tijdperk beslaat de oude Hebreeuwse geneeskunde van de bijbel. De tweede periode bevat de Talmoedische tijd. De derde periode komt overeen met de Middeleeuwen. De vierde periode tenslotte is de periode vanaf het einde van de achttiende eeuw tot in onze tijd (Enc.Jud.,Vol.11,1178). Deze indeling heb ik tot leidraad genomen voor dit hoofdstuk. Gezien de in de joodse traditie kenmerkende samenhang van de schriftelijke Torah met de mondelinge (zie hoofdstuk 3), heb ik de beide eerste perioden samengevoegd tot één. Deze periode loopt tot ruwweg de vierde à vijfde eeuw na Christus. Na een overgangstijd loopt dan de midden-periode door tot in de achttiende eeuw. De derde periode neemt in de tweede helft van de achttiende eeuw een aanvang, als de gedachten van de Verlichting zich doorzetten (vgl. Buber $1957,1971^{3}, 42$; Rosenzweig 1937,378).

Het zou een studie op zich zijn om voor elke periode tot een afgerond geheel te komen met betrekking tot het thema gezondheid en genezen in de joodse traditie. Hiernaar heb ik in deze verkennende studie niet gestreefd. Het is bovendien een taak voor de terzake geinteresseerde historicus. Ik beperk me tot enkele belangrijke momenten en personen.

In het eerste deel van dit hoofdstuk ga ik in op de achtergrond en betekenis van gezondheid en genezen in de Bijbel en Talmoed. Het woord genezen komt in de Hebreeuwse bijbel veelvul- 
dig voor, in enge en, vaker, in ruime zin. Ik heb een keuze gemaakt voor één centrale tekst, die ik aan de hand van rabbijnse interpretaties nader uitwerk (4.2.1.). Vervolgens ga ik globaal in op achtergrond en betekenis van genezen en gezondheid in het oude Israël $(4.2 .2)$. Ook geef ik enkele korte karakteristieken weer van de geneeskunde in het oude Israël. In een laatste paragraaf van dit eerste deel ga ik in op het gebed om genezing, zoals dit dagelijks aan de orde is in een van de oudste gebeden uit de joodse traditie, het 'Sjemone Esre' of 'Achttiengebed' (4.2.3.).

In de midden-periode valt op dat veel joodse talmoedisten tevens arts waren. zowel door zijn positie als talmoedgeleerde en kenner van de rabbijnse traditie als door zijn inzicht in gezondheid en genezen op basis van zijn vorming als westerse wijsgeer en arts overtreft Maimonides (1135-1204) iedereen in name en faam. Maimonides was enerzijds verbonden met de rabbijnse traditie, terwijl hij anderzijds ook van de toenmalige westerse denktraditie op de hoogte was. Hij kende de oude joodse en de arabische geneeskundige en gezondheidsopvattingen. Tevens is hij een schakel in de lijn die van Galenus (129-201) naar onze hedendaagse westerse geneeskunde leidt. Malmonides trachtte de joodse wijze van weten en het westerse denken met elkaar te verbinden. Ook dit makt hem tot een sleutelfiguur. Aan hem en aan zijn werk besteed ik in het tweede deel van dit hoofdstuk aandacht (4.3).

Tenslotte besteed ik in een laatste deel aandacht aan de derde periode. In deze meest recente periode valt op, dat onder invloed van de Verilchting en de Franse Revolutie veel joden hun exfgoed hebben verlaten en zich als geassimileerde joden hebben aangesloten bij de Europees-westerse kultuur (zie hoofdstuk 2). Zij gingen universitaire opleidingen volgen, studeerden onder meer medicijnen, en leverden een bijdrage a an de verdere ontwikkeling van de westerse universitaire geneeskunde (zie 
Enc.Juc., Vol.11,1195-1211). Ik werk dit overigens niet uit, hoe interessant een dergelijk overzicht voor de geschiedenis van de geneeskunde ook moge zijn.

Hiler gat het meer om de aard en de strekking van het joodse weten als oriëntatie voor gezondheld en genezen in de meest ruime zin. Zeer kort zeg ik lets over de moderne halacha in relatie tot de geneeskunde. Ik teken hierbij aan dat het om een synthese gaat en dat de moderne geneeskunde niet in tegenspraak met de halacha hoeft te zijn. In een korte notitie ga ik ook in op de situatie in de staat Israel, met name noem ik Beer sheva. In Israël makt niet alleen de moderne gezonaheidszorg grote opgang, mar tegelijk dienen in dit land de verordeningen uit de joodse traditie als levensordening voor de daar levende gemeenschap. Hier ligt het geestelijk centrum war het joodse weten, de joodse traditie, voortgezet en verder ontwikkeld wordt. Overigens is de relatie tussen de traditie van de Torah en Israel als staat een vraagstuk apart, waarop ik niet verder inga. Ik beperk me tot deze en tot de in de betreffende paragraaf (4.4.1.) aan de orde zijnde verwijzing. Tot slot ga ik in dit deel nog in op de relatie van de filosofisch-joodse literatuur met gezondheid en genezen. Met name bespreek ik enkele aspekten uit het werk van Martin Buber (4.2.2.).

4.2. Gezondheid en genezen in Bilbel en Talmoed.

4.2.1. "Denn ICH bin dein Arzt".

Het thema gezonaheid en genezen in de joodse traditie in (de tijd van) de bijbel en de talmoed kan men op twee nivo's benaderen. Het ene nivo betreft vooral de geneeskundige toepas- 
sing en de konkrete gezondheidsregels. Het tweede nivo is van meer existentieel-antropologische aard. In 4.2 .2 . leg ik wat meer op het eerste de nadruk. Hier, en ook weer in 4.2.3. is vooral het tweede nivo aan de orde. In het voorafgaande hoofdstuk heb ik al aangegeven, dat de bevrijding uit Egypte, met alle hierbij behorende gebeurtenissen, de kern vormt van de joodse identiteit. Tot deze gebeurtenissen hoort ook de akseptatie van de Torah als richtsnoer voor het leven. Leven en daarmee gezondheid en genezen worden rechtstreeks in verband gebracht met een op de Torah betrokken levenswijze.

De beslissende keuze van het joodse volk - een keuze waar elke generatie en iedere mens steeds weer voor komt te staan - houdt de erkenning in, dat het niet de natuur of een 'natuurgod", dat wil zeggen "a mysterious deity behind the natural forces" (Epstein 1955, $1980^{\circ}, 285$ ) is, die het menselijk (gezonde) leven bepalt. Het komt niet met de menselijkheid van de mens overeen als hij zijn leven aan de natuur ondergeschikt makt. Het mens zijn is niet uitsluitend van de natuur afhankelijk (vgl.Heschel 1965,3). De Egyptenaren beschouwden het menselijk leven wel als aan de natuur ondergeschikt. zij dienden de natuur in de gestalte van de leven brengende zonnegod 'Ra'.

ook komt het niet met de menselijke waardigheid overeen, dat de mens aan een andere mens ondergeschikt is, een god van vlees en bloed, een 'Pharao' (vgl. Fromm 1975,50-65). De joodse traditie laat zien dat Mozes en degenen die met hem wegtrokken het aandurfden voor een geheel eigen en aparte wijze van leven verantwoordelijk te zijn en dat zij niet langer de gestalte van een menselijke 'godheid' dienstbaarheid wilden betonen. De Hebreeuwse denkbeelden betekenden zo een omwenteling in de wereldgeschiedenis (Chouraqui 1979,38).

overigens betreft het hier niet een strikt menselijke behoefte of verlangen naar vrij- 
heid, maar een dialogisch gebeuren. De bron van het juiste en goede menselijke leven stoelt niet op eigen behoeften en zij wordt niet langer in immanente of (boven)natuurlijke machten gezocht, maar zij is het verlangen yan de transcendente God (Heschel 1955,1976 ${ }^{3}$ ). Epstein noemt Gods liefde voor Israel "the first step to the recognition of His love for a11 men" (Epstein 1954,1980 ,285). In het verlengde hiervan moet de uitverkiezing van Israel ook nlet als een natuurlijke selektie beschouwd worden, mar als een uitverkiezing tot dienstbaarheid.

Als de Torah de dienst aan de "natuurgod" 'Ra' - en aan de "mensengod' - de 'pharao' afwijst, is dit een verwijzing naar een derde levensweg, die dan als de juiste gezien wordt. Deze weg wordt de dienst aan de Ene God genoemd. Het is de weg yan de Torah en de 'mitswot" (Leibowitz 1978 ${ }^{2}, 72$ ). Hij wordt in verband gebracht met gezondheid, ziekte en genezen en met God als de eerste en de uiteindelijke geneesheer:

"Und sprach:

Willst hören du, hören auf SEINE, deines Gottes, Stimme

und was gerad ist in seinen Augen tun, seinen Geboten lauschen

und all seine Gesetze wahren: -

will ich von aller Krankheit, die ich auf Aegypten legte, nichts auf dich legen.

Denn ICH bin dein Arzt"

(Namen 15,$26 ; \mathrm{Ex} .15: 26)$.

Leven met de Torah, leven voor Gods aangezicht (zie Gen.17:1), is geen strikt religieuze zaak, maar het raakt de gezondheid van de gehele mens. Het is een zaak, die de mens heel konkreet, aan den lijve, goed doet. De traditionele uitleg wijst ook hierop. In de Tanchoema staat: "Der Heilige, gesegnet-sei-Erl, sprach zu den Israeliten: Die Worte der Tora, die ich euch gegeben habe, die heilen euch, wie es heisst: 'Das wird deinem leibe gesund 
sein' usw. (Prov.3:8)" (Midrasch Tanchuma B, IV, 19).

Dok latere kommentatoren, zoals Rashi en Hirsch, wijzen erop, dat ziekte het gevolg is van het niet (onder)houden van de Torah. Rashi (wiens volledige naam Rabbi Sjlomo ben Jitschak luidde), een van $\bar{d}$ e bekendste kommeñtatoren uit de Middeleeuwen (1040-1105), zegt: "Eet die zaak niet, opdat het u niet tot deze ziekten ( $\mathrm{nl}$, de ziekten waamee Hij de Egyptenaren trof - J.R.) brenge; zoo ook zegt men: genezing zal het (de opvolging van de voorschriften Gods) zijn voor uw lichaam (spr. $3,8)$ " (Onderwijzer 5657/1897,Vol.II,200). Ook het kommentaar van Hirsch laat aan duidelijkheid niets te wensen over: "Keeping the divine law is the most preventive medicine against all physical and social evil" (Hirsch,Vol.II, 1976,207 ).

God wordt als een arts gezien en deze verwijzing wordt weer op de 'aanwijzingen ten leven' uit de Torah betrokken. In de Mechilta, een aan Rabbi Isjmaël toegeschreven midrasjverzameling op Exodus, staat: "And why does scripture say: 'For I am the Lord that healeth thee'? God said to Moses: Say to Israel: The words of the Torah which I have given you are life unto you, as it is said: 'For they are life unto those that find them" (Prov.4,22). They are health unto you, as it is sald: "It shall be health to thy navel and marrow to they bones" (ibid.3,8)" (Mekilta, Vol.II,96). Cassuto, een hedendaagse kommentator, geeft aan de woorden "for I am the Lord your healer" de uitleg: "and just as I (God) have now healed the water, so I wilf protect you from al1 sickness" (Cassuto 1974 , 184-185). Dit. is een verwijzing naar 2 Koningen $2: 19-22$, waar we kunnen lezen, dat door toedoen van de profeet Elisa het slechte water van Jericho gezond werd gemaakt.

In het Hebreeuws betekenen de woorden 'Rofe El': God geneest. Het woord voor arts is 'rofe'. "Rofe El' betekent niet alleen God 
geneest, maar ook: God is arts, en ook: God de genezer. De naam Rafaël is hiervan afgeleid en betekent dus: God geneest. Toen de doodzieke Franz Rosenzweig nog een zoon kreeg, was hij zo verheugd, dat hij hem de naam Rafaël gaf.

"Wahret meine Satzungen

und meine Rechtsgeheisse,

als welche der Mensch tut und lebt durch sie. ICH bins" (Er Rief 18,5; Lev.18:5).

De mens die de aanwijzingen van de Torah wil leren kennen, kan er alleen beter op worden. "Damit Ihr lebet" (Reden 4,1;Deut.4:1). Zo lemand kan alleen mar meer gaan leven, een gezonder mens worden, "but not die by them" (Bab.Ta1. Abodah Zarah 27b). Overigens gaat dit alleen op als men zonder dwang en belangeloos hiertoe overgaat (id.,54a; Abram 1980, 224).

Het zal duidelijk zijn, dat het hier om het gezonde bestaan in de meest ruime betekenis van het woord gaat (zie hoofdstuk 1). De aanwijzingen van de Torah betreffen het leven in al zijn facetten, somatisch, psychisch, sociaal. Het gaat om regels op hygiënisch, sociaal, juridisch en moreel gebied. Bij' 'leven' gaat het om een bestaan warin de mens verbondenheid ervaart met God en zijn Torah, met de wereld en met de medemens. De Misjna zegt: "Great is Torah for it gives life, unto those that practice 1t" (Mishnah, Aboth VI, 7). Ook in de Talmoed leggen de Rabbijnen een verband tussen gezondheid en (studie van) de Torah. Zo in het traktaat Berachot: "R.Simenon b.Lakish says: If one studies the Torah, painful sufferings are kept away from him" (Bab.Talm.,Berakoth $5 \mathrm{a}$ ).

Als het volk Israel zich afzijdig houdt van de studie van de Torah en de levensregels van de Torah niet opvolgt, zullen rampen, ziekte, slavernij en onrust het gevolg zijn en het gemeenschapsleven en de sociale struktuur van het leven zullen uiteen vallen. Zowel het volk als 'het weten' omtrent de joodse wijze van 
leven zullen uiteengerukt en verstrooid worden (zie Deut.28:58-62). Zowel het gemeenschapsleven als het bezit van een geestelijk thuisland verdwijnen. Het leidt tot vervreemding, leegheid en vormloosheid, zegt de Talmoed. Het betekent voor de mens een totaal verlies aan levensoriëntatie (Bab.Talm., Shabbath 88a). Als iemand wel de weg van de Torah volgt (vgl. Gen.17:1; Deut.18:13; Deut.28:9) betekent dit dat hij zich goed en gezond gedraagt, merkt Hirsch op (Hirsch, Vol v,561-562). Als hij dit niet doet, wordt hij ziek. De Talmoed zegt: "Rather (should you say): If one has the opportunity to study the Torah and does not study it, the Holy one, blessed be He, visits him with ugly and painful sufferings which stir him up. For it is said: "I was dumb with silence, I kept silence from the good thing, and my pain was stirred up" (Ps.XXXIX,3). "The good thing' refers only to the Torah, as it is said: "For I give you good doctrine; forsake not My teaching' (Prov. IV, 2)" (Bab.Talm.,Berakoth 5a). De Talmoed zegt ook: "If ye accept the Torah it is well; if not, there shall be your burial" (id., Shabbath 88a;vgl.id.,Ta'anith 7a).

4.2.2. Gezondheid en genezen in 'het oude Israèl'.

Een traditie die zo de nadruk legt op het mens zijn en op de waardigheid van de mens als de joodse, moet voor het leven wel bijzonder veel over hebben. "Judaism regards human life as being of infinite and inestimable value", zegt Bleich in zijn boek 'Judaism and Healing' (Bleich 1981,22). En Schindler zegt: "In Jewish thinking human life is valued as supreme. The preservation of human life is paramount and one is obligated to do all even if live is extended for only a short period of time. The value of human life is infinite and 
beyond measure so that a hundred years and a single second are equally precious" (Schindler 1983,12). Kortorn: "Human life is inviolably sacred" (Franck 1983,211).

Het menselijk leven is zeer bijzonder en van zeer hoge warde en de mens moet alle moeite doen het te koesteren en te bewaren (vgl.Bab. Talm. Baba Mezia 112a). "As a moral desideratum it takes precedence over virtually all other values. Exceptions to the general rule that preservation of 1 ife takes precedence over all other considerations are transgression of the three cardinal sins for purposes of preserving life. These are: murder (hardly and exception), idolatry, and sexual offenses such as incest and adultery. All other laws are suspended for purposes of conservation of life" (Bleich 1981,22). Bleich sluit hiermee aan bij een regel die de rabbijnen reeds in de literatuur van het oude Israël geformuleerd hebben en die als zodanig in de Talmoed opgenomen is (Bab.Talm., Sanhedrin 74a).

Dispensatie krijgt men zelfs bij de sabbatsheiliging. Deze mag niet ten koste gaan van eigen of andermans leven (Abraham 1980,27; zie ook Enc.Jud., Vol.14,566). De basisgedachte van deze regel werd door de rabbijnen in de Misjna geformuleerd: "R. Mittithiah b. Hersch said: If a man has a pain in his throat they may drop medicine into his mouth on the sabbath, since there is doubt wether life is in danger. and whenever there is doubt whether life is in danger this overrides the Sabbath" (Mishnah, Yoma VIII,7). Om de zieke terwille te zijn, wijken de regels van de sabbat. "If a man put out the lamp (on the night of sabbath) (...) to suffer one that was sick to sleep, he is not culpable" (id., Sabbath II, 5).

De verantwoordelijkheid die men voor elkaars leven en gezondheid heeft, leiden de rabbijnen onder andere af van de woorden: "steh nicht still bei dem Blut delnes Genossen" (Er Rief 19,16:Lev.19:16), en ook van het vers: "dann gibs $1 \mathrm{hm}$ zurick" (Reden 22,2; Deut.22:2). Ik ga 
op deze plats hierop niet verder in. In hoofdstuk $6 \mathrm{kom}$ ik erop terug.

Het 'waarmaken" en bewaren van het leven geldt zowel het eigen leven als dat van de ander. Volgens de interpretaties van de rabbijnen is de mens niet alleen persoonlijk verantwoordelijk voor zijn buurman als deze materieel verlies heeft geleden, maar ook als deze 'zichzelf' heeft verloren (Bab.Talm., Sanhedrin 73a; ook Hirsch, Vol.III, 1976,521;vgl. Lev. 19, m.n.vs. 16-18).

Niet alleen is het leven in het algemeen van de hoogste orde, maar ook met ieder moment van het leven is dit het geval (Bleich 1981,22). Bovendien is niet alleen ieder moment van het leven van onschatbare warde, mar belangrijker is nog dat het leven van elke persoon van onschatbare waarde is. Deze houding komt goed naar voren in een Misjna- en Talmoedpassage die handelt over de schepping van Adam.

"Therefore but a single man was created in the world, to teach that if any man has caused a single soul to perish from Israel (some texts omit "from Israel") Scripture imputes it to him as though he had caused a whole world to perish" (Mishnah, Sanhedrin IV,5;zie ook ARN XXXI, 125).

Overigens wordt zonde met de dood gelijkgesteld en, zoals ik al aangaf, hebben de rabbijnen vastgesteld dat "idolatry, incest, (which includes aldultery) and murder" (Bab. Talm., Sanhedrin 74a) onder geen enkele voorwaarde toegestaan zijn, ook niet om het eigen leven te redden. Dit betekent impliciet dat alleen onder dwang van de omstandigheden martelaarschap toegestaan is. Het martelaarschap is dus geen nastrevenswaardige verdienste (vgl. ook de rol van de Griekse held, o.a. bij Rosenzweig $\left.1921,1976^{4}, 83-90\right)$, maar een verdienste ondanks zichzelf.

In dit verband merk ik nog op dat ook het leven van een ander niet onder alle omstandigheden gered mag worden. De Misjna zegt: "These 
may be delivered (from transgression) at the cost of their lives: he that pursues after his fellow to kill him, or after a male, or after a girl that is betrothed; but he that pursues after a beast, or that profanes the sabbath, or that commits idolatry - they may not be delivered (from transgression) at the cost of their Iives" (Mishnah, Sanhedrin VIII, 7). Op deze tekst bestaat nog een uitgebreide 'gemara', letterlijk 'lering', die als rabbijns kommentaar in de Talmoed is opgenomen. Het zou teveel ruinte vragen op deze plaats hierop in te gaan (zie Bab.Talm. "Sanhedrin 73a-b en $74 a-b)$.

Het bewaren en "waarmaken" van het leven heeft een aantal zwaarwegende konsekwenties. De rabbijnen hebben hieraan vorm gegeven in de vorm van leefregels op de meest uiteenlopende gebieden van het leven. Een van de meest voor de hand liggende aanwijzingen, die op het behouden en doorgeven van "leven" gericht is, is de regel te trouwen en kinderen voort te brengen (zie Gen.9:7). De Talmoed vergelijkt een goede vrouw met de Torah. "How precious is a good wife with whom the Torah is compared" (Bab. Talm. "Yebamoth 63b). Ook het leren kennen van de Torah brengt leven voort! Een goede vrouw wordt evenals de Torah een kostbaar geschenk genoemd. (id., Yebamoth 63b). We zagen eerder (hoofdstuk 3), dat ook de Torah een kostbaar geschenk genoend wordt.

Niet alleen bestaat de regel dat men voor het leven en de gezondheid van de ander verantwoordelijk is, mar het is ook leders plicht en verantwoordelijkheld voor het eigen leven zorg te aragen. Dit doet men impliciet als men de aanwijzingen van de traditie volgt. voor een traditie die "slechts in én leven gelooft en die er altijd de nadruk op heeft gelegd dat de mens een geheel is in physiek, sociaal en religleus opzicht" (Baruch 1961,69) betekent dit, dat het leven in alle opzichten op gezond mens zijn gericht was en dat dit nog zo is tot 
op de dag van vandaag. Ik noem hier de aspekten van de tijdsordening, van de hygiënische voorschriften en andere leefregels, allemal aanwijzingen die reeds in 'het oude Israël' gegeven zijn. "Although the old Testament is not a medical text, its historical accounts, laws and precepts, and even its wording, yield an abundant harvest of information concerning the structure of the human body, diseases, injuries, cures and, above all, preventive and sanitary procedures" (Muntner 1971,XV-XVI).

Vooral vanuit het oogpunt van wat wij geestelijke gezondheid noemen is de tot de dag van vandaag bestaande joodse tijdsordening aktueel. "Het jodendom heeft de tijd geordend: de dag met zijn morgen-, middag- en avondgebed; de week met zijn sjabbat en werkdagen, de maand met zijn nieuwemaan-dag; het jaar met zijn cyclus van feesten die inderdaad het jaar omspannen" (zuidema $1977,1982^{4}, 87$ ). De tijdsordening is voor de mens belangrijk. De ordening van de tijd betekent tegelijk een ordening van het leven (id..89).

Een van de grootste weldaden voor de mensheid is wel het ritme van zes werkdagen en één rustdag, welk ritme door de westerse wereld van het jodendom is overgenomen (Baruch 1961, 17). De sabbat is niet alleen uit sociaal oogpunt en uit het oogpunt van lichamelijke rust belangrijk, maar vooral omdat hij het leven in een tijdsperspektief plaatst. Heschel. die een prachtig boekje over de sabbat en de betekenis ervan voor de hedendaagse mens schreef, zegt: "The Sabbath is a day for the sake of life" (Heschel 1951,1977\%,14) en hij noemt de sabbat 'een paleis in de tijd' (id., 15; vgl. Rosenstock-Huessy 1966). In het vijfde hoofdstuk kom ik hierop nog terug.

Het gezond mens zijn is in de joodse traditie van oudsher ook bevorderd door een uitgewogen stelsel van hygiënische voorschriften, door de spijswetten en door sociaal-ekonomische leefregels. De leefregels zijn niet alleen uit 
Lichamelijk oogpunt van belang, maar ook omdat zij geestelijke, morele en sociale implikaties hebben (Cohen 1932,254-255). Een rabbijns gezegde luidt: "Physical cleanliness leads to spiritual purity" (Bab.Talm. Abodah Zarah 2Ob). Zo leveren bijvoorbeeld de spijswetten een bijdrage an de (geestelijke) gezondheid van de mensen en hun gemeenschap, omdat zij "een halt toeroepen aan de veelheid van mogelifkheden, om daardoor een bepalde rem in het leven aan te brengen" (Soetendorp 1970,133; zie ook De Vries $\left.1927-1932,1978^{4}\right)$. Een rationele verklaring voor de spijswetten valt slechts tot op zekere hoogte te geven. zij bevestigen eerder het apart gesteld zijn en het eigen karakter van het volk Israel dan dat zij altijd rationeel inzichtelijk zijn.

Van de in totaal 613 voorschriften die in de Torah genoemd worden, hebben er 213 een medisch c.q. gezondheidkundig karakter. Hieronder vallen de aanwijzingen met betrekking tot de preventie van epidemieën, het onderarukken van prostitutie en van venerische ziekten, de zorg voor de huid, het veelvuldig wassen, de eetgewoonten, de sanitaire gebruiken, de aanbevelingen met betrekking tot de seksuele ongang, de regels ten aanzien van isolatie en quarantaine e.d.; maar ook de aanwijzingen met betrekking tot de naleving van de sabbat horen hiertoe (Enc.Jud., Vol.11,1179).

ook de sociale en ekonomische regels zijn weloverwogen en gericht op het gezonde bestaan in de meest ruime zin. Evenals de hiervoor genoemde voorschriften betreft het hier 'aanwijzingen ten leven warvan de joodse traditie in lange jaren van leven in uiterst moeilijke onstandigheden geleerd heeft dat zij de juiste en de beste zijn om het leven en daarmee het gezond mens zijn te behouden. Deze regels hebben dan betrekking op huwelijk en gezin, op het leven in de gemeenschap en op het elgendomsrecht (Bernant 1976:vgl. Feldman $1968,1978^{3}$, Brachfeld $\left.1975,99-127\right)$. Kenmerkend 
is ook de solidariteit binnen de eigen groep. de gastvrijheid tegenover vreemdelingen en het asielrecht voor de stamlozen (Nijs 1979).

De gerechtigheid die 'de weduwe en de wees" behoeft, wordt zo hoog opgenomen dat deze uitdrukking als pars pro toto wordt gebruikt voor ieder die op de een of andere wijze en om de een of andere reden vernederd en weerloos is: de arme, de gevangene, de gemartelde, de lichamelijk en geestelijk lijdende of ontredderde en eenzame medemens (Burggraeve 1977. 193). "Mozes en de profeten bekommeren zich niet om de onsterfelijkheid van de ziel, mar om de arme, de weduwe, de ${ }_{2}$ wees en de vreemdeling" (Levinas $1969,1971^{2}, 45$ ). Levinas verbindt hier de konsekwentie an dat deze ander voor mij niet alleen 'weduwe en wees' is, maar tegelijk ook "mijn rechter" (Kwant 1966,616). Met deze ander heeft de Ander (God) tegelijk ook een "geheim verbond" (Bakker 1979).

De zieke is iemand die weerloos is en zoals God zelf de zieken bezoekt en hen helpt, zo is de mens in staat achter de goddelijke 'sjechina! (Gods aanwezigheid in de wereld) aan te wandelen en de ander bij te staan (zie Micha $6: 8 ; \mathrm{vgl}$. Rosenzweig $1921,1976^{4}, 471$ ). "The Holy One, blessed be He, visited the sick ( $\mathrm{I}$. in de gestalte van drie vreemdelingen - J.R.), for it is written, 'And the Lord appeared unto him by the oaks of Mamre' (Gen.XVIII, 1. Since the proceeding verses deal with Abraham's circumcision, it is deduced that the occasion was when he was recovering), so do thou also visit the sick" (Bab.Talm. Sotah 14a).

De geneeskunde nam in het jodendom van bijbel en talmoed geen aparte en daardoor geisoleerde plaats in. Het jodendom kende veel minder dan bijvoorbeeld de Egyptische en Griekse kulturen een specifiek joodse geneeskunde. Ook waren er geen aparte scholen of specialisaties. De zorg voor de gezondheid was geintegreerd in het leven van de gemeenschap (Waaijman 1981,14-15). "De arts is één faktor binnen de totale ge- 
meenschapszorg" (id.,15). De literatuur wijst erop dat voor de arts een plats ingeruima moet worden. Walijman citeert Jesus sirach (tweede eeuw v.Chr.): "Voor de arts moet je ook een plaats inruimen, want ook hij is door Jahweh geschapen. Laat hij niet van je wijken. want ook hem heb je nodig. Er zijn immers ogenblikken dat de goede afloop in $z i j n$ handen ligt, want ook de artsen bidden Jahweh dat hij hun een gelukkige diagnose mag geven en genezing mag brengen tot behoud van het leven" (Jesus sirach 38:12-14, bij Waaijman 1981,1516).

De arts in het oude Israel zou men wat zijn plaats en funktie betreft wel kunnen vergelijken met de huisarts bij ons. Evenals onze huisartsgeneeskunde was de joodse geneeskunde gericht op de zorg voor individu, gezin en gemeenschap (Preuss 1911,1969,1971,10; Baruch $1961,85)$. Weliswat waren zijn therapeutische mogelijkheden beperkt. Muntner noemt de volgende: "washing, baths, orthopedic bandages, ointments and herb medicines" (Muntner 1971. XVIII). Even verder op geeft hij nog een aanvuliing: "anointments with oils, balm, compresses, squeezing of abcesses to remove pus" (id., XX).

De 'rofe' was vaak rabbijn of leraar en arts tegelijk. Overigens kende het oude Israël ook een zeker onderscheid. De handhaving van de gezonaheidsregels behoorde vooral tot de taak van de rabbijnen, terwijl de artsen zich bezig hielden met de behandeling van de zieken (vgl. 1d. , XVI).

Noch de situatie van het ziek zijn, noch de plaats van de arts hadden het gersoleerde karakter dat ziekte en geneeskunde bij ons ten deel valt en warbij een "elite van deskundigen" voor de genezing verantwoordelijk gesteld wordt (Waaijman 1981, 15). Ziekenhuizen waren onbekend, a thoewe 1 uit 2 samuel $15: 17$ en uit 2 Koningen 15:15 afgeleid kan worden, dat men wel een 'bet merhak' een 'huis ver weg' kende. waarschljniljk moet hierbij gedacht worden aan 
een quarantainebarak buiten de stad (Muntner 1971,XVIII).

Niet alleen was de positie van de joodse geneeskunde anders dan die van het oude Egypte, ook de eraan ten grondslag liggende intentie was een andere. Ik wijs er op dat in het jodendom het doen een sterke nadruk heeft. Weten is onlosmakelijk met handelen verbonden en omgekeerd. In het jodendom gaat het niet om een theoretisch-wetenschappelijke geneeskunde. De mens en zijn gemeenschap hadden de arts om praktische redenen nodig. De arts had een plaats en taak in het leven van alledag. Een leerling mag niet langer dan nodig ziek blijven. Anders kan hij niet 'lernen'. "A disciple of the sages should not reside in a city in which there is no physician" (Bab.Talm., Sanhedrin 176;id. Kidushin 66a).

Volgens de joodse traditie wordt de arts gezien als helper van God (zie Jesus sirach $38: 1-15)$. De arts heeft niet het laatste woord. "In the Israelite monotheistic conceptual scheme there was no room for "healers'. Only God could 'heal' sickness. In Israel there were only 'helpers' who treated patients" (Muntner 1971,XIX), met andere woorden "healing was in the hands of God and the role of doctors was that of helpers or instruments of God" (Enc.Jud.,Vol.11.1179; vgl.Elke Morgen Nieuw 1979,215; Wolff 1973, 217-220). Veelal wordt dan naar de eerder uitgewerkte Torah-tekst verwezen, die zegt: "Denn ICH bin dein Arzt" (Namen 15,26;Ex.15: 26). De artsen kunnen louter de patiënt behandelen, en zij hebben ook de plicht dit te doen, voorzover dit binnen de mogelijkheden van de mens en binnen de mogelijkheden van de natuur ligt. Medicijnen en andere ingrepen hebben niet het laatste woord (Abraham 1980, 14). Alleen God kan werkelijk genezen: "Er, der heilt..." (Ps.147,3).

Het vertrouwen op God betekent geen blindelingse overgave. Er wordt van de mens verwacht 
dat hil gebruik makt van de mogelijkheden van de geneeskunde en van de arts. "Whoever is in pain, let him go to the physician" (Bab.Talm., Baba Kamma 46a). Zowel de zieke als de arts hebben de verantwoordelijkheid mee te werken met de natuur en met Gods plan.

Ik moet er hier ook op wijzen dat gezondheid, zlekte en genezen in het jodendom niet a an magische of mythische invloeden toegeschreven worden (vgl.Munter 1971, XX). Okkultisme, magie, geestesverering zijn niet toegestaan. In de Torah staat: "ICH bins. Wendet euch nimmer zu den Elben und zu den Wisserischen, sucht sie nimmer auf, maklig zu werden an ihnen. Ich bin euer Gott" (Er Rief 19,31; Lev.19:31; vgl. 1d.,20:6). Steeds weer komt naar voren dat God de uiteindelijke genezer is. Met behulp van de hem hiervoor ten dienste staande natuurlijke middelen moet de mens wel al het mogelijke doen om genezing te bevorderen.

Men kan dus zeggen dat de geneeskunde, 'chokmat ha-refoea', het joodse volk van oudsher bekend was. Binnen de mogelijkheden van de natuur en van de mens werd er positief en aktief gebruik van gemaakt. In de Hebreeuwse bijbel wordt onder meer naar de geneeskunde verwezen in Exodus 21:19; verder in 2 Kronieken 16:12, wat duidelijk gezegd wordt dat koning Abba van Juda geen hulp zocht bij God, maar bij de 'heelmeester'. In 2 Koningen 20:7 stat een verwijzing nat het gebruik van bepadide middelen bij het genezen. Ook in de Misjna en in de Talmoed vindt men allerlei verwijzingen naar artsen, naar de geneeskunde en naar de zorg voor een goede hygiëne en gezondheid.

De aanwijzingen die op gezondheid en genezen betrekking hebben, staan door de hele Misjna en Talmoed heen. Dit is ook niet verwonderlijk, als men het joodse weten opvat als weten met betrekking tot leven en tot gezond (heel) mens zijn in de meest ruime zin. Specifieke aandacht krijgt de gezondheid van de mens in 
de zesde en latste seder (= deel) van de Misjna en de "Talmoed, de seder "Teharot" of 'Tohorot' (= reinheid), die op $\mathrm{zijn}$ beurt weer verdeeld is in twaalf traktaten.

Uit de Misjna en de Talmoed blijkt, dat de oude joodse geleerden een diepgaand inzicht hadden in het funktioneren van het menselijk lichaam en in wat men menselijk gezond gedrag zou kunnen noemen (Keller,z.j.,159). Preuss heeft in zijn boek 'Biblisch-talmudische Medizin' de geneeskunde van het oude Israël op systematische wijze beschreven (Preuss 1911, 1969,1971 ).

Het streven naar gezondheid en gaafheid zijn in het jodendom geen op zichzelf staande doeleinden. "'Zelfaktualisatie' is niet de uiteindelijke bestemming van de mens", zegt Frankl (Frankl 1980,35). En: "Als we van het streven naar gezondheid ons hoofddoel maken, zijn we in werkelijkheid ziek" (id.,37). Het streven naar gezondheid moeten we zien in samenhang met de reden die iemand kan hebben om gezond te zijn (vgl.id,,36; Leibowitz 5740/1980,315). Het voorgaande betreft de in beginsel gezonde mens, maar het heeft evenzeer betrekking op de genezing van een ziek iemand. "Genezing is meer dan niet meer ziek zijn; het is bevrijd zijn van de ziekte, zodat de mens weer ruimte en mogelijkheden heeft om te werken aan zijn opdracht" (Elke Morgen Nieuw 1978,218). De gezonde mens weet zich verantwoordelijk en hij zal in zijn leven(ssituatie) trachten te handelen naar Gods bedoeling: "Zend mij genezing... opdat ik je dienst kan dienen en je verordeningen kan hpuden met een volkomen hart" (Singer 1962 $2417 ; \mathbb{E} 1 \mathrm{ke}$ Morgen Nieuw 1978,218 ).

Hier vooral ligt voor de joodse traditie de 'zin' van het leven. Overigens: "in platis van over de 'zin' van het leven te spreken, spreken we in de joodse traditie liever over de bestemming van de mens; en die ligt in het zichtbaar maken in de wereld van het beeld van 
God warnaar hij is geschapen" (Aschkenasy $1978,140)$.

Daarom ook is geneeskundige hulp op de sabbat toegestaan en zelfs verplicht: "So that he (de zieke) may keep many sabbaths" (Talm.Bab. "Yoma $85 \mathrm{~b})$. En in een kommentaar op Exodus staat bij Exodus $31: 12-17$ over het onderhouden van de sabbat: "the sabbath is given to you, but you are not surrendered to the Sabbath, $R$. Nathan says: Behold it says 'Wherefore the children of Israel shall keep the sabbath or observe the sabbath troughout their generations' (v.16). This implies that we should disregard one sabbath for the sake of saving the life of a person so that that person may be able to observe many Sabbaths" (Mekilta,vol.III,198199).

Zo is het ook de bedoeling van de achtste "beracha" (bede) uit het Achttiengebed (waarover dadelijk meer) "van onze God te vragen dat $H i j$ ons geneest met een volledige genezing, opdat wij gezond en sterk zijn om ons op passende wijze bezig te kunnen houden met de Tora en alle geboden te kunnen onderhouden" (Otsar ha-Tefilot 5683-1923/5720-1960,336;Elke Morgen Nieuw $1978,87-88$ ). In ruime zin gaat het bij deze verantwoordelijkheid ook om genezen: "genezen, heel maken, heil brengen is de fundamentele opdracht van de mens in de wexeld $^{\text {"n }}$ (Poorthuis 1982,26 ). En ook - en hier richt deze studie zich op - is het leren kennen van de Torah op zichzelf een bezigheid die genezing bewerkstelligt: "Said the Holy one, blessed be He: "There is no affliction for which there does not exist a cure; the therapy and medicament for every affliction is discernible. If you seek that misfortune betall not your body engage in the study of Torah, for it is a therapy for the entire body" (Tanchuma Yitro 8 , bij Bleich 1981,VII). 
Het jodendom richt zich in heel zijn 'doen en horen' (vgl.Ex.24:7) op God. Het meest pregnant komt dit in het bidden naar voren. Het gebed is in de joodse traditie geen individuele gerichtheid op God, maar het is een sociaal gebeuren, een zaak van de gemeenschap (Misnah, Aboth III,6). Het is een 'mitswa' of gebod om elke dag te bidden, want er is gezegd: "IHM, eurem Gott, dientl" (Namen 23,25; $E x \cdot 23: 25)$. Door deze woorden in $\mathrm{zij}$ Torah heeft hij dat de mensen laten weten. De wortel van het gebed is niet zozeer de behoefte van de mens, maar het verlangen van God (Van Uden 1978,3). De kern van de joodse gebedstraditie vormt het 'sjema Israël', warvan de beginwoorden luiden:

"Höre Jissrael: ER unser Gott, Er einer!" (Namen 6,$4 ; \mathrm{Ex} \cdot 6: 4$ ).

Met dit gebed wil de vrome jood tot in het diepst van zijn hart en tot in alle vezels van zijn lichaam zijn God, "ER einer!", dienen, tot op het moment van zijn dood toe. "Het is de wens van een gelovige jood, bij volle bewustzijn te mogen sterven, met het 'sjema' op zijn lippen. Dat is de belijdenis uit Deut. $6: 4$ 'Hoor Israël, de Heer is onze God, de Heer is EENI'. En dan de klanken van het laatste woord zo te mogen aanhouden, dat zij met het wijken van de laatste adem verklinken" (Zuidema $1977,1982,188)$.

Naast het 'sjema Israël' behoort het 'sjemone Esre' of 'Achttiengebed' tot het dagelijkse gebed van de vrome jood. Het gebed wordt staande uitgesproken. Vandaar dat het ook "Amida", dat 'staand" betekent, wordt genoemd (Bab.Talm.,Megillah 17b). Dit gebed bestaat uit negentien (oorspronkelijk achttien; vandaar de naam) 'berachot' (meervoud van "beracha', zegenspreuk, bede, lofprijzing). De achtste beracha betreft een bede om genezing. Deze luidt als volgt:

"Genees ons Heer, dan zijn we genezen, 
bevrijd ons, dan zijn we bevrijd, want gij zijt onze lof (ook wel: roem). En breng volledige genezing voor al onze slagen (ook wel: voor al onze plagen). want God, Koning, een geneesheer trouw en barmhartig zijt Gij (ook wel: want God, Koning, trouw en barmhartig genezer zijt Gij). Gezegend zijt Gij, Heer, die de zieken van zijn Volk Iscaêl geneest look wel: Gezegend Gij Heer, die de zieken van Israël zijn Volk geneest)" (Elke Morgen Nieuw 1978,15 en 86).

In de uitleg die in het boek "Elke Morgen Nieuw" bij dit gebed gegeven wordt, zeggen de schrijvers dat de beginwoorden 'Genees ons, Heer" betekenen: "het begin komt van u". De woorden 'dan zijn we genezen' houden in: "dat wij het proces dan afmaken" (Otsar ha-Tefilot $5683-1923 / 5720-1960,337$; Elke Morgen Nieuw 1978,87). God is eerst en om diens plan af te maken wil de mens Gods bedoeling leren kennen. "Genezen is ten diepste in de handen van God, maar de mens kan en moet zijn kennis en bekwaamheden gebruiken" (id.,45;vgl.id. 215; Baruch 1961,14;zie ook de vorige paragraaf).

Ieder heeft zijn eigen verantwoordelijkheid en zijn eigen mogelijkheden. Maar uiteindelijk is genezing en ook gezond mens zijn een zaak van God: "Ook al laat de Heer, Hij zij gezegend, in elke generatie geneesheren en bevrijders uit de mensenkinderen voor ons opstaan, de genezing en de bevrijding die zij brengen is niet volledig; pas als de Heer ons geneest, dan zijn wijgenezen en als Hij ons bevrijdt, dan zijn wij bevrijd met een permanente bevrijaing" (otsar ha-Tefilot 5683-1923/5720$1960,336$; Elke Morgen Nieuw 1978,215$)$.

De genezing waarom gebeden wordt, is de genezing van de gehele mens. En dit is een volgend facet dat van belang is. Onder genezing wordt niet alleen lichamelijke maar ook geestelijke genezing verstaan (Elke Morgen Nieuw 1978,87 en 213). Dit komt naar voren in de bede die na 
de vierde regel van de achtste beracha gezegd wordt als een familielid, bekende of vriend ziek is. Deze toegevoegde bede luidt:

"En moge het jouw wil zijn, Heer onze God en God van onze vaderen, dat je snel zendt volledige genezing van de hemel, genezing van ziel en genezing van lichaam, aan de zieke $\mathrm{NN}$

temidden van de rest van de zieken" (id., 213).

Deze volledige genezing van de mens wordt voor elke zieke gevraagd, wat ook de aard van zijn ziekte is, somatisch of niet-somatisch (id., 214). Toch is er ook een onderscheid. Voor de genezing van het lichaam kan de mens "hoogstens de voorwaarden scheppen voor de 'natuurlijke genezingsprocessen!' maar dat dié het zijn, die de genezing voltooien. Ten aanzien van de ziel kunnen we het dus wél verder zelf, maar ten aanzien van het lichaam niet" (id., 87).

Maar er is nóg meer. Niet alleen komt in dit gebed de verbondenheid met God tot uiting en niet alleen heeft de bede betrekking op wat wij de psychosomatische dimensie noemen, ook worden de maatschappelijke omstandigheden en het matschappelijk leed waarmee mensen in de vorm van schande, onderdrukking, ongelukken, e.d. te maken kunnen krijgen, erbij betrokken. Om dit te kunnen inzien moeten we de bijbelteksten die an deze beracha ten grondslag liggen raadplegen.

Dit betreft vooreerst de reeds genoemde woorden "Denn ICH bin dein Arzt" (Namen 15,26; Ex. 15:26). Deze woorden hebben namelijk betrekking op de maatschappelijke omstandigheden en het leed dat de joden in Egypte gekend hebben en op de bevrijaing hiervan (Elke Morgen Nieuw 1978,217).

De tweede tekst die aan de beracha ten grondslag ligt is de volgende:

"Heile mich, DU, 
dann bin ich heil.

befreie mich,

dann bin ich frei.

Ja, du bist mein Ruhm"

(Jirmejahu 17,14:Jer.17:14).

De samenstellers van "Elke Morgen Nieuw" verwijzen bij dit vers naar een kommentaar van Rabbi David Kimchi (1160-1235). Kimchi betrekt in zijn uitleg ook de verzen 15 en 18. De tekst van vers 15 luidt als volgt:

"Wohl, jene sprechen zu mir:

Wo bleibt nun SEINE Rede?

komme sie doch!"

(Jirme jahu 17,15; Jer.17:15).

En het tweede stukje warnaar verwezen wordt, klinkt zo:

"Lass beschämt werden meine Verfolger, nimmer möge beschämt werden ich,

besturzt lasse jene werden,

nimmer möge besturzt werden $i c h$,

auf sie lass den Tag des Bösgeschicks kommen, mit gedoppeltem Bruch brich sie nieder!"

(id.,17,18;id.,17:18).

Hieruit blijkt, zo leert Rabbi Kimchi, dat "de profeet niet alleen om genezing van ziekte vraagt, maar ook om genezing van de smaad en de vervloeking warmee $z i j n$ vervolgers hem overladen en die hem ziek maken van ellende" (Ejke Morgen Nieuw 1978, 214).

Een viexde en laatste facet warmee genezen en gezond mens zijn te maken hebben, is de verbondenheid tussen de individuele persoon en de gemeenschap (Van Uden 1978,32-35; Kadushin 1963,109). In de joodse traditie zijn bidaen en gebed tegelijkertijd een persoonlijke zaak en een zaak van de gemeenschap. ook het individuele gebed is met de gemeenschap verbonden (zie Rosenzweig, hoofdstuk 2). "Het gebed is zeker een hoogst persoonlijke zaak, maar het isoleert de mens niet van de gemeenschap; integendeel, het verbindt hem juist met de gemeenschap" (Van Uden 1978,32). In het Achttiengebed wordt gevraagd: 'genees ons'. Dit is 
anders dan in de oorspronkelijke tekst van de profeet Jeremia. Deze zegt: 'genees mij'. De bede 'genees ons' heeft betrekking op de gemeenschap Isrä̈l zoals die nu bestaat en zoals die door de eeuwen heen in verleden en toekomst bestaat. Overigens is op een andere plaats in Jeremia, namelijk in 30,17 - "net als in vele andere Bijbelteksten die over genezing gaan", zo zegt Elke Morgen Nieuw "sprake van de genezing van het volk als geheel" (Elke Morgen Nieuw 1978,215). De tekst van het genoemde vers is als volgt:

"Ja,

ich lasse Wundhaut dich iberziehn, von deinen Schlägen heile ich dich. ist SEIN Erlauten,

'Verstossene" riefen sie dich ja schon:

'zion ists, - der fragt keiner nach!"

(Jirmejahu 30,$17 ;$ Jer. 30:17).

In het Achttiengebed wordt genezing gevraagd van de gehele mens. "zowel van de lichamelijke slagen als van de zielsverwondingen" (Otsar ha-Tefilot 5683-1923/5720-1960,337;Elke Morgen Nieuw 1978,87). Het woord genezen heeft tevens een "psychologische inhoud", in de zin van "weer helemal mens worden", zo zeggen de uitleggers van het Achttiengebed. Zij verwijzen dan naar Hirsch die het Hebreeuwse woord 'refoea' (genezing) verklaart als herstel van ziekte en het woord 'jesjoea' (bevrijding) als de gave van een vernieuwd en levenslustig, en in deze zin genezen - wezen. In de tweede regel van de $8 \mathrm{e}$ beracha wordt het woord genezen haast ongemerkt overgenomen door het woord "bevrijden". Het betekent dan verlossen van al de plagen die de mens kunnen overkomen en "redden uit de nood" (vgl. Elke Morgen Nieuw 1978,87 ). Genezing heeft betrekking op genezing en bevrijding van somatische, psychische alsmede van matschappelijke nood. En JHWH wordt aangesproken als 'helper", als 'bevrijder' en als 'schild'. Dit gebeurt in de le beracha van het Achttiengebed. De auteurs 
verwijzen naar Jawitz die de volgende uitleg geeft:

"- helper, die de mens bijstaat en hem van zijn kracht geeft om zijn daden te doen slagen:

- bevrijder, die de mens wegtrekt uit de nood warin hij is gekomen;

- schild, en hem beschermt tegen alle ellende die hem belaagt" (id.,62).

4.3. Genees - en gezondheidkunde in de Middeleeuwen: Mozes Maimonides.

Maimonides (1135-1204) hoort thuis in de rij van belangrijke joodse geleerden in de Middeleeuwen. Deze geleerden vervulden veelal tevens een brugfunktie tussen de arabische en de christelijke westerse kultuur (Stemberger 1977,107). Hun positie hield mede in dat hun werk een dubbel karakter had: rabbijns én filosofisch-joods. De aksenten lagen soms meer op de rabbijnse wijze van bijbelvertolking. soms meer op de systematiek zoals die in de filosofie gebruikelijk is.

Bekende namen uit de eerste groep zijn saadia ben Josef Gaon (892-942), Rabbi Salomo ben Isaak, kortweg Raschi genoema (1040-1105), Abraham Ibn Esra (1089-1164), de arts Mose ben Nachman, ook Nachmanides genoema (1194-1270), de staatsman Don Isaak Abravanel (1437-1509) en Joseph Caro (1488-1575). Met name het hoofdwerk van Caro, de 'Sjoelchan Aroech' (letterlijk: "gedekte tafel"), is gezaghebbend tot in onze tijd. Het bevat onder meer voorschriften die betrekking hebben op ziekte, dood en rouwbeklag en gedragsregels die op de persoonlijke levenssfeer van toepassing zijn (voor een systematische samenvatting verwijs ik naar Goldin 1953).

Vertegenwoordigers van de tweede groep zijn Solomon Ibn Gabirol (ca.1020-ca.1057), de arts en dichter Jehuda Halevi (vóór 1075-1141) die 
wij bij Rosenzweig reeds tegenkwamen (zie hoofdstuk 2), Abraham Ibn Daud (ca.1110-1180), Mozes ben Maimon, ook Malmonides genaama (1135-1204), en Levi ben Gershom (1288-1344). Veel joodse geleerden in de Middeleeuwen waren tevens arts. Aardig om te vermelden is, dat joodse geleerden, samen met arabische artsen, ook betrokken waren bij de oprichting van de eerste 'medische fakulteit' in Europa in 846 in het Italiaanse Salerno (Keller z.j.,159). Pas in 1119 volgt Bologna, waarna langzamerhand overal in Europa universiteiten gesticht worden. Keller: "Terwijl de joodse geneeskunde aanvankelijk op de kennis en de ervaringen uit de wereld van het oude Oosten stoelde, heeft later het medische speurwerk in de islamitische cultuursfeer de Joden tot in de nieuwe tijd tot vooraanstaande dragers van deze wetenschap gemaakt en het grote aandeel van de Joden in de moderne medische wetenschap voorbereid" (Keller z.j.,159;Enc.Jud.,Vol.11,1178$1211)$.

Mozes Maimonides - in het Hebreeuws Mosje ben Maimon en in het Arabisch Abu-Amran genoemd, maar ook bekend onder de naam "Rambam' "van Rabbi Mosje ben Maimon - is wel de bekenste joodse arts en wijsgeer uit de Middeleeuwen. Hij genoot in deze hoedanigheid niet alleen onder joden bekendheid, maar zijn invloed strekte zich ook uit tot de toenmalige westerse geneeskunde en de (christelijke) filosofie. ook de arabieren makten van zijn kennis en kunde dankbaar gebruik.

Maimonides was een veelzijdig geleerde: behalve geneeskundige en gezonaheidkundige was hij ook wiskundige en sterrenkundige en naast filosoof ook talmoedgeleerde, dat wil zeggen kenner van de rabbijnse literatuurtraditie.

Al deze kwaliteiten waren bij Mozes ben Maimon geen gescheiden zaken, mar hij verenigde ze in zijn persoon en hij handelde hiernaar. Voor Maimonides stond gezond mens zijn in het teken van de integriteit en de levensbesteming van 
de mens en dit beperkte zich niet tot de lichamelijke gezondheid. Zijn bekwaamheid als arts en zijn inzicht tot in de diepte van de menselijke gezondheid vertoonden een integraal karakter.

Behalve als praktiserend arts kreeg Maimonides bekendheid door zijn geschriften over gezondheid en over de vraag hoe gezond mens te zijn. Hij stelde zijn inzichten met betrekking tot het gezonde bestaan en zijn bekwaamheid als arts ten dienste van een-ieder die hem konsulteerde. Een van zijn dankbare (arabische) patiënten schreef dit loflied:

"Galen's arts heals only the body

But Abu-Amran's (Maimonides) the body and the soul.

His knowledge made him the physician of the century.

He could heal with his wisdom the sickness of the ignorance.

If the moon would submit to his arts,

He would free her of the spots at the time of the full moon,

Would deliver her of her periodic defects, And at the time of her conjunction save her Erom warning". .

(Enc.Jud. ,Vo1.11,778).

Maimonides werd op 30 maart 1135 in Cordova geboren. Omstreeks zijn dertiende jaar moest hij vluchten vanwege de vervolging van de joden. Hij kwam terecht in Fez in Noord-Afrika. Vandaar moesten $h i j$ en zijn familie in 1165 opnieuw vertrekken en via Akko, Jeruzalem en Hebron belandde hij uiteindelijk in Egypte. In Fostad - de oude stad van CaIro - werd hij de lijfarts van Al-Fadil, de vizier van sultan Saladin. Deze positie stelde hem in staat tot het schrijuen van enkele voor de joodse traditie belangwekkende werken. Daarnaast publiceerde hij nogal wat aanwijzingen over gezond mens zijn. Deze geschriften hebben soms uitsluitend op het thema gezondheid betrekking. mar soms ook maken zij deel uit van de meer 
wijsgerige werken. ook deze laatste zijn altijd - in de meest ruime zin - 'aanwijzingen ten leven". Maimonides overleed op 13 december 1204. Hij werd in Tiberias begraven (Enc.Jud., Vol.11,754-781; Twersky 1974,187-214).

De grootste verdienste van Maimonides is het schrijven van de 'Misjne Torah', letterlijk: 'de herhaling van de Torah'. De literatuur van de mondelinge traditie had langzamerhand zo'n grote omvang gekregen en was langzamerhand zo ingewikkeld geworden, dat er dringend behoefte was aan een 'handboek'.

Met zijn 'Misjne Torah' wilde Maimonides bereiken, dat men met betrekking tot de joodse levensleer aan dit nieuwe kompendium voldoende had. Dit in 1180 voltooide werk van Rambam is een systematisch kommentaar op de Misjna. Het werk begint met een algemene inleiding op de mondelinge Torah, de ketting van de traditie en de wijze van ordening van de Misjna. Vervolgens behandelt hij de halacha in vier groepen: de verhouding van de mensen tot God, de levensordeningen van de mensen (gezin, feesten, etc.), de regels die met het land Isräl 1 te maken hebben en, tenslotte, het civiel-en strafrecht (stemberger 1977,114). In de 'Misjne Torah' is ook een hoofdstuk opgenomen, dat op het thema gezondheid betrekking heeft (niet in een vertaling beschikbaar).

Met de kodeks 'Misjne Torah' slaagde Maimonides erin het gehele kompleks van de traditionele joodse leer op een overzichtelijke en stelselmatige manier samen te vatten en te rubriceren. Hij leverde zo, op weer een geheel eigen manier, een bijdrage aan "de onafzienbare zee van joodse literatuur", die steeds aangroeit en waarvan gezegd wordt, dat er "wel altijd bijkomt, maar nooit iets afgaat" , omdat "iedere duidingsmogelijkheid kostbaar is en waard om te worden bewaard" (Aschkenasy en Whitlau 1981,7$)$. Zo werd ook Rambam met zijn werk opgenomen in de keten van joodse geleerden en leraren die met Mozes begint en die 
zich tot op de dag van vandaag uitstrekt (vgl. Mishnah, Avoth I, 1).

Naast de "Misjne Torah" is ook de "More Nevoekim', letterlijk 'de Gids van de Verdoolden' een bekend en belangrijk werk van Maimonides. In deze studie onderneemt hij een grootse poging geloof en kennis met elkaar in overeenstemming te brengen. Ook het verstand is een bron van openbaring. Tussen de traditie van de Hebreeuwse bijbel en de wetenschap kan geen tegenstrijdigheid bestaan (Munz 1912,168169; Guttman 1966,175; Hartman 5737/1976).

Om een, terzake van ons thema relevant, inzicht te krijgen in het werk van Maimonides parafraseer ik enkele hoofdstukken, namelijk I,42 en III,27, uit de Gids der Verdoolden. Maimonides werkt in deel $I$, hoofdstuk 42 uit wat de betekenis is van het woord 'levend' ('chaj' in het Hebreeuws). Dit woord, zo zegt hij, wijst op iets dat groeit en dat kan gewaarworden. 'Levend" wijst ook op het (kunnen) herstellen van een ernstige ziekte. Maimonides verwijst dan naar Jesaja $38: 9$, Jozua $5: 8$ en Leviticus 13:10. Maar ook het woord 'dood' wijst, behalve naar de dood, naar een ernstige ziekte (zie 1 Samuel 25:37, 1 Koninger 17:17). Vervolgens wijst Maimonides er op, dat 'levend vak gebruikt wordt in de zin van het verkijgen van kennis. Zo in spreuken 3:22, Spreuken $8: 35$ en Spreuken $4: 22$. Juiste richtlijnen worden met 'leven' en verkeerde met 'dood' in verband gebracht (zie Deuteronomium $30: 15)$. Zo ook het goede en het kwade (zie Deuteronomium $5: 30$ en 22:7). Maimonides besluit hoofdstuk 42 met een verwijzing naar de Talmoed (Bab.Talm. Berakoth $18 \mathrm{a}-\mathrm{b}$ ), waar staat: "The righteous even in death are called living, (whereas) the wicked even in life are called dead" (Maimonides 1963, Vol. I, 92-93).

In hoofdstuk 27 uit deel II gaat Maimonides in op de betekenis van de Torah. De Torah heeft, zegt hij hier, zowel de gezondheid van de ziel (geest) als van het lichaam op het 
oog. Terwille van het eerste staan in de Torah duidelijke levensaanwijzingen, naast ook verhalen. Ten aanzien van het lichamelijk welzijn wijst Maimonides erop, dat de levensomstandigheden van dien aard behoren te $\mathrm{zijn}$, dat geweld en eigenmachtig optreden niet toegestaan worden, maar dat het gaat on het dienen van het geheel. Bovendien moet het iedereen mogelijk gemaakt worden die kwaliteit van leven te verkrijgen die van warde is voor het leven van de gemeenschap. Het geestelijk en het lichamelijk welzijn hebben ieder hun eigen warde. Gezondheid van het Iichaam vereist voedsel, onderdak, de mogelijkheid tot baden, enz... . Dit kan alleen in gemeenschappelijk verband gerealiseerd worden. Een mens die pijn moet lijden, honger en dorst kent of het koud heeft, kan nooit optimal zijn verstandelijke kapaciteiten gebruiken en studeren. De juiste levensaanwijzingen, zegt Maimonides dan, zijn die van de Torah van Mozes. Zij verwijst naar het welzijn van de mensen in hun onderlinge relaties, alsmede naar iemands persoonlijke goede gesteldheid. Zoals in Deuteronomium $6: 24$ staat:

"Er gebot uns, all diese Gesetze zu tun,

IHN unsern Gott zu fürchten,

uns zu Gute für alle Tage,

uns am Leben zu halten,

wies nun an Tag ist" (Reden 6,24).

De Torah verwijst naar welzijn en een lang leven (vgl.Deut.22:7). De rabbijnen verbinden hieraan de konklusie, dat het om een wereld gaat warin iedereen gezond en wel is en die lang mag bestaan. Een goede politieke ordening van de gemeenschap is hiervoor noodzakelijk.

Een van de bekende werken uit de 'gezondheidsleer" van Maimonides is de in het Arabisch geschreven 'zendbrief aan Al-Afdal' met als titel 'Fi Tadbir al-sikha' oftewel 'de gids voor een goede gezondheid'. Het gaat hier om gezondheidsaanwijzingen en -inzichten die ook voor ons nog leerzaam zijn. Maimonides lat in 
deze tekst onder meer zien, dat ziel en lichaam weliswaar te onderscheiden zijn, maar dat het mens zijn juist bestaat in hun eenheid. De mens is allereerst mens. Voorts wijst Maimonides erop, dat de arts zich wel degelijk met de 'uitingen van de ziel' dient bezig te houden (Van der Hoog z.j.,200-206). Dat Maimonides een gezonde geest belangrijk vindt voor de gezondheid moge onder andere uit de volgende uitspraak uit het boek 'Pirke Mosche' ("de spreuken van Mozes') blijken. "Eine freudige Erregung der seele ist fur die Gesundheit besser als die Bewegung des Körpers" (Mün 1912,282). Dit is een opvallende uitspraak in onze tijd met har nadruk op het gezonde lichaam en op lichaamsbeweging.

Maimonides verwijst met betrekking tot de 'uitingen van de ziel' naar de wijsbegeerte. Behalve de "normatieve ethica' en de 'moraliteitsleer' noemt hij de leer die de profeten en hun volgelingen ons hebben nagelaten. Dit betekent een regelrechte verwijzing naar de joodse levens- en literatuurtraditie als richtingbepaling voor het leven.

De hier bedoelde samenhang tussen gezond mens zijn en leven naar en horen (leren) van de Torah komt, behalve in de "More Nevoekiem' en de zendbrief aan Al-Afdal nog in een ander gezondheid- en geneeskundig belangrijk werk van Maimonides naar voren, namelijk in de 'sjemone Perakiem' ('de Acht Hoofdstukken'). Dit werk is een uitvoerige en fijnzinnige inleiding op een kommentaar op het Misjnatraktaat 'Pirke Avoth' ('spreuken der Vaderen'). De 'Acht Hoofastukken' zijn ook nu nog zeer de moeite van het bestuderen en bespreken waard (zie Gorfinkle 1.966; Wolff 1863).

Behalve de Acht Hoofdstukken vinden we in dit Misjna-kommentaar een ander werk, dat grote bekendheid gekregen heeft, namelijk 'de Dertien Principes (artikelen) van de (joodse) lering', in het Hebreeuws 'Sj'lossa-esser. Ikkeriem" genoemd (zie Ben Chorin 1975, 1979 ). In de gezondheid- en geneeskunde bracht Maimo- 
nides de volgende driedeling aan:

- preventieve geneeskunde. Deze kwam vooral tot uiting in zijn gezondheidkundige opvattingen;

- genezen van zieken. Hier baseerde Maimonides zich op de inzichten van die tijd, warbij hij nog het voordeel had van de kennis van de arabische geneeskunde;

- zorg voor herstellenden en voor invaliden en bejaarden (Enc.Jud., Vol.11,778).

Van Maimonides is bekend dat hij een man van het midden, een man van evenwicht en harmonie was. De harmonieuze opstelling geldt ook voor zijn geschriften. Zo wilde hij met zijn 'More Nevoekiem', de Gids der Verdoolden, een levenshandleiding bieden aan mensen die in twijfel staan of de Torah als openbaring van God opgevat moet worden of als een boek dat op menselijke ervaring en gezond verstand berust. Maimonides vatte de Torah op als een boek, dat met menselijke woorden spreekt, maar waaruit, als het ware door deze buitenkant omgeven, toch een geinspireerde bedoeling spreekt (vgl. Van der Hoog $z \cdot j \cdot, 20-21$ ).

Ook met betrekking tot het menselijk gezond gedrag hield Maimonides van een evenwichtige leefwijze. Zo is het niet goed voor de mens als hij al te passief is, maar ook is het niet gezond als hij al te aktief bezig is. Alle uitersten verdienen afkeuring, zegt Maimonides in het vierde hoofdstuk van de 'Sjemone perakiem'. Goede handelingen zijn die, die blijk geven van de gulden middenweg. Dit geldt bijvoorbeeld voor de seksualiteit. Passiviteit en zelfkastijding zijn uit den boze, evenals een al te aktieve opstelling. Het vinden en bewaren van een evenwicht hierin leidt tot een gezonde wijze van leven. En dit is weer belangrijk om voldoende rustig en ontspannen te zijn voor de studie van de Torah.

De middenpositie die Malmonides in veel opzichten inneemt, komt ook in het karakter van zijn werk naar voren. Maimonides beoogde het 
filosofische denken te verbinden met en te integreren in de schriftelijke en de mondelinge Torah. Hij veronderstelde dat de joodse traditie verrijkt kon worden door een filosofisch begrijpen van God (Hartman 5737-1976. $1977^{2}, 67$ ).

Uit de biografie van Mozes ben Maimon is nog bekend, dat hij zich eerst schoolde in 'de wijsheid van het leven'. dat wil zeggen in filosofie en in Talmoed, voordat hij de stap naar de geneeskundige studie en praktijk makte. Voor hem was dit een vanzelfsprekende volgorde. "The medical problem is but one aspect of a complex human problem", zo geeft een hedendaags wetenschapper en 'leerling' van Maimonides het hier aan de orde zijnde punt weer (Hartman 1978,42; id.1979,102).

Het verhaal over de gulden middenweg, over een evenwichtige levenshouding en over "alles met mate is in feite een klassiek Grieks verhaal. De rationele Griekse wijsheid - 'chokma' in het Hebreeuws - en de Griekse esthetica hebben de joodse traditie niet onberoerd gelaten. Toch ontwikkelden de geschriften van de Talmoed en de andere literatuur zich vrij onafhankelijk van de overheersende kulturen, zoals het hellenisme. Dit wordt anders in de Middeleeuwen. De kodices van de joodse traditie mogen dan wel de levensregels van de Torah tot inhoud hebben, maar de systematiek en manier van verwoorden wijzen op een integratie van het Griekse en Hebreeuwse denken.

Zo wilde Gabirol (ca.1020-ca.1057) het jodendom in overeenstemming brengen met de filosofie van Plato (vgl. in onze tijd Levinas). In zijn, in de vorm van dialogen geschreven, werk "Mekor Chajiem" (de Bron van het leven) gaat hij uit van een eerste principe, een eerste Idee. Deze identificeert hij met God (Enc. Jud. ,vol. 7,235-246).

Naast een neo-platonisch school $\mathrm{kwam}$ een neo-aristotelische richting tot ontwikkeling. Hiervan is Maimonides de belangrijkste verte- 
genwoordiger. Aristoteles ging uit van de samenhang tussen stof en vorm. Maimonides heeft dit principe overgenomen en toegepast op de samenhang van lichaam en ziel. Het houdt in, dat als het een verandert, ook het andere verandert. Als het lichaam verandert, verandert ook de ziel en omgekeerd. Maar een lichaam zonder ziel kan evenmin bestaan als een ziel zonder lichaam. De beweging, de verandering zelf, voert Maimonides terug tot een eerste weten: God.

De ziel is een eenheid, mar zij openbat zich wel op meerdere manieren, zegt Maimonides in zijn 'Sjemone Perachiem' (bij Garfunkle $1966,37)$. De geestelijk-rationele manier is de hoogste uitingsvorm. De hoogste geestelijke waarden met betrekking tot het leven zijn door de profeten ontwikkeld. De joodse geleerden bouwen hierop voort. In deze zin noemt Maimonides Mozes en de profeten dan ook geleerden en filosofen. Op deze wijze ook beoogt Maimonides het weten van de joodse traditie te integreren in het Grieks-westerse weten.

Met de vermogens of uitingen van de ziel gaat het erom zo dicht mogelijk bij God te komen en zijn Torah te leren kennen. De ziel moet daarom gezond zijn. De profeten hebben zo'n gezonde ziel. Mar als je wil filosoferen (= leren) en de hoogste levenswaarden (nl. die in de Torah verwoord zijn) wil bereiken, moet je ook voor je lichaam zorgen. Een gezonde ziel (geest) en een gezond lichaam hebben voor Maimonides uiteindelijk geen esthetische betekenis zoals in het oude Griekenland.

Maimonides en vele anderen in zijn tija met hem hebben het Griekse kultuurgoed op een hoger plan gebracht door het te verbinden met de profetische wijsheid van de Torah.

Dat Maimonides ook in onze tijd niet geheel vergeten is, blijkt uit het 'Ochtenagebed van Maimonides'. Het is opgenomen in de door de Koninklijke Nederlandsche Matschappij tot Bevordering der Geneeskunst uitgegeven 'Ge- 
dragsregels voor Artsen' (gebaseerd op datgene wat door de medische professie verstaan wordt onder zorgvuldig handelen, de beroepsuitoefening in ruime zin betreffende). Ik besluit deze paragraaf met dit gebed:

"sta mij bij Almachtige, in het volbrengen mijner moeilijke taak, opdat zij gelukke, want zonder UW bijstand is de mensch zelf niet tot het geringste in staat.

Beziel mij met liefde tot mijn kunst en Uwe schepselen; laat niet toe dat geld of roemzucht mijn daden beinvloeden, want deze vijanden der wartheld en menschenliefde kunnen mij licht op dwalwegen voeren en mij van mijn plicht Uw kinderen wel te doen, afhouden.

Verruim mijn hart, zoodat dit steeds bereid is arm en rijk, vriend en vijand, den kwade zoowel als den goede te helpen.

Laat mij in den lijder alleen den mensch zien; geef mij de kracht mij aan het bed van den zieke te beheerschen, zoodat $z$ ich geen vreemde gedachten aan mij opdringen en al mijn ervaring en kennis mij geheel ten dienste staan om hem te helpen. Schenk mijn zieken vertrouwen in mij en mijn kunst, opdat zij mijn voorschriften en aanwijzingen getrouwelijk opvolgen.

Verleen mij, o God, geduld en zachtheid, wanneer een zieke mij weerstreeft. Schenk mij gematigdheid in alles, behalve in mijn verlangen naar kennis.

Geef mij bescheldenheid, zoodat hoogmoedige gedachten over mijn bekwamheid ver van mij blijven.

omgord mijn lendenen als met een pantser, wanneer onkundigen mij bespotten, opdat mijn geest ongekwetst blijve en ondanks andere invloeden de warheid oprecht zoeke. Indien echter wijzere mannen het beter willen leren, laat mijn geest dankbaar den aangewezen weg volgen, want het gebiled der artsenijkunst is groot.

Amen" (Gedragsregels 1978,26,zie ook Van Es $1980,155-156)$. 
Eén korte aantekening moet ik hierbij maken. Het is opmerkelijk, dat de K.N.M.G. dit gebed, dat begint met een bede tot de God van het joodse volk, zonder meer na(ast) de Eed van Hippokrates plaatst. Deze uit een geheel andere beschaving (de Griekse) staminende eed begint als volgt: "Ik zweer bij Apol10, den genezer, bij Asklepios, bij Hygieia, bij Panceia en alle goden en godinnen, hen tot getuigen makend, naar mijn vermogen en oordeel, dezen eed, deze verbintenis ten uitvoer te zullen brengen" (Gedragsregels 1978,25; vgl.Van der Hoeven 1963,15$)$.

Als men de beginwoorden van de beide teksten vergelijkt leidt dit tot een konfrontatie van twee verschillende levenskonsepten, waarbij een keuze niet uit kan blijven. In onze westerse wereld zijn deze beide duidelijk te onderscheiden bronnen a anwezig. Maar: "Er gaapt een kloof tussen deze (de semitische) geesteshouding en de tweede geestelijke bron van waaruit onze westerse cultuur wordt gevoed, nl. de klassieke oudheid" (Wesiack 1976, 24). Zoals het nu in de gedragsregels stat lijkt het een hinken op twee gedachten te zijn.

$\frac{\text { 4.4. Gezondheid en genezen in het }}{\text { huidige jodendom. }}$

4.4.1. Rabbijnse opvattingen.

De rabbijnse literatuur met betrekking tot gezondheid en genezen valt in twee delen uiteen. Op de eerste plaats is ex de normatief-halachische literatuur. Ik geef hiernaar slechts een korte verwijzing. Daarnaast is er de meer "beschouwende" literatuur. Deze is niet direkt op gedragsregels gericht, maar meer op het geven van een levensperspektief. 
In beide gevallen betreft het literatuur die de geneeskunde en gezondheidsvragen tot uitgangspunt neemt en deze verbindt met de joodse traditie c.q. vanuit de joodse traditie uitspraken over geneeskundige en gezondheidkundige kwesties doet.

Genezen heeft tot doel "om de mens op de weg van het leven te voeren, om hem in verbondenheid met andere mensen te brengen en hem in stat te stellen de verantwoordelijkheid voor het geheel weer op te nemen" (Poorthuis 1982, 27). "The telos of human existence is service of God and the performance of his commandments" (Bleich 1981,25). De mens die gezond is kan beter hieraan voldoen dan iemand die dit niet is.

Afhankelijk van de ernst van de ziekte gelden verschillende gedragsregels voor deelname aan het gemeenschapsleven en de verantwoordelijkheid hiervoor. De moderne halacha kent vier kategorieën van ziek zijn: "the seriously i11", "the non-seriously ill", "minor illness" en "discomfort". De halacha geeft van elke kategorie een nadere, gedetailleerde, omschrijving $_{2}$ (zie Abraham 1980,1-3;Jakobovits 1959, $\left.1975^{2}, 59-81\right)$.

Zoals de zieke de plicht heeft genezing te zoeken, zo heeft de arts de plicht tot het instellen van een geneeskundige behandeling. "The very fact that the Torah has permitted the medical treatment of the sick makes it a mitzvah for the physician to do so, and, if he avoids it, such behaviour is equivalent to the "shedding of blood". If the patient is seriously ill and requests a particular physician to treat him, that physician should do so even if others are available" (Abraham 1980, 1.10; Bab.Talm., Sanhedrin 73a;vgl. Lev.19:16).

De positie van de arts wordt mede hierdoor ondersteund, doordat in het jodendom diens studie en beroep essentieel voor het welzijn van de mensheid genoemd worden. Het is de arts bijvoorbeeld toegestaan om op de sabbat zijn 
vak bij te houden (Abraham 1980,108). Ook mag zijn hulp op de sabbat worden ingeroepen, als het tenminste om een serieuze ziekte gat. overigens mag de arts zich niet op zijn deskundigheid en adviezen laten voorstaan. Hij mag hiervoor ook geen extra loon vragen. Alleen voor zijn inspanning en voor de gespendeerde tijd heeft hij recht op inkomen (id.. 14).

Een belangrijk punt in de medische halacha is, dat de medisch(-technische) mogelijkheden en gezondheidsvoorzieningen als zodanig niet ter diskussie staan. Het is de situatie die uitmakt wat wel, en wat niet gedaan moet worden (zie ook hoofdstuk 1 ). Het helpen van iemand die ziek is, is een morele plicht. "In treating a patient he (the doctor) is morally involved" (Heschel $1975^{5}, 31$ ).

In de meer 'beschouwende' rabbijnse literatuur gat het niet direkt om de konkrete halachische aanwijzingen, maar meer om opvattingen die overeenkomstig de joodse traditie zijn. Het gaat hierbij om een divers geheel van geschriften. Als thema spelen gezondheid en genezen overigens geen grote rol. Ik beperk me dan ook tot een enkele korte en met name in de persoonlijk-relationele sfeer belangrijke, verwijzing.

De eerste auteur die ik wil noemen is Abraham Joshua Heschel. Heschel wijst erop dat de patiënt op een existentieel-antropologisch nivo zijn intrede doet bij de arts. De patiënt is primair in zijn persoon zijn aangetast. alhoewel hij als patiënt mogelijk ook farager van een ziekte is (Heschel $1959,1975^{5}, 24$ ). Heschel merkt dan op dat dit van de arts eveneens een antropologische bewustwording vraagt: "You can only sense a person if you are a person" (id.,27).

De zin van het genezen ligt niet in het doen van allerlei medisch-technische handelingen, maar hierin dat deze toepassingen nodig zijn terwille van het leven van een 'bijzonder' en 
uniek iemand (vgl.Rosenzweig, hoofdstuk 2). "Every man is an extraordinary man" (Heschel 1.955. $\left.1976^{3}, 27\right)$.

Wat de arts moet bewegen is niet technische interesse, maar "human compassion". "The mother of medicine is not human curiosity but human compassion (...). Physics may be studied as a pure science, medicine must never be practiced for its own sake. In contrast to time gone by, the doctor"s role has broadened from healing the sick to serving all men, ill and well. However, I will limit myself to the role of the physician as a healer, a supreme test of this role in the life of society. What manner of man is the doctor? Life abounds in works and achievement, in areas of excellence and beauty, but the physician is a person who has chosen to go to the areas of distress, to pay attention to sickness and affliction, to injury and anguish. Medicine is more than a profession. Medicine has a soul, and its calling involves not only the application of knowledge and the exercise of skill but also facing a human situation. It is not an occupation for those to whom career is more precious than humanity of for those who value comfort and serenity above service to others. The doctgr's mission is prophetic" (Heschel 1959. $1975^{5}, 28$ ).

Dat Heschel de opdracht van de arts 'profetisch' noemt, wijst erop dat hij a an het handelen van de arts een bijzondere plates toekent (vgl.Heschel 1955,1976 339 ). Voor Heschel is een profeet iemand die zich lat lelden door de nood van 'de weduwe, de wees en de vreemdeling', zoals dit in bijbelse termen uitgedrukt wordt. De profeet is een vurig voorvechter voor een rechtvalardige wereld. De situatie en toestand van de mensen zet hem in beweging. De profeet werkt niet aan eigen grootheid, macht of rijkdom, mar hij identiflceert aich met het leven en de levenssituatie van de mensen. Een profeet is iemand, zegt Heschel, die de wereld vanuit Gods gezichts- 
punt benadert (Heschel 1962,1969 $2,3-26$ ).

Van belang is niet alleen, dat een patiënt van zijn ziekte geneest, mar dat hij als mens geneest. In de arts-patiëntrelatie behoort dit tot uiting te komen. "The relationship of the physician to the patient involves more than curing a disease", merkt David Hartman op, de tweede auteur aan wie ik hier kort aandacht besteed (Hartman 1978,42). De dokter, zo geeft Hartman aan, moet zich niet als een omnipotente vader gedragen. Dit kan in onze onvolmakte wereld slechts tot frustratie leiden. Hartman pleit voor een relatie warbij de arts en de patiënt aksepteren, dat zij van elkar afhankelijk zijn en dat zij behoren samen te werken. Van een eenzijdige afhankelijkheidsrelatie, gericht op het genezen van de ziekte van de patiënt, of van een eenzijdige 'samenwerking' kan geen sprake zijn (id.,48;zie ook id. 1979, 98-112).

Hartman merkt voorts op, dat de (preventieve) geneeskunde alleen gelegitimeerd kan worden als de arts beseft dat hij primair met levende mensen te maken heeft in plaats van met patiënten die van een ziekte moeten genezen. Dit vraagt niet om een vóótijdig ingrijpen en zeker niet om een ingrijpen dat achter de feiten aanloopt, maar om een tijdig ingrijpen, om een handelen op het juiste moment (vgl. Rosenzweig $1921,1976,297-306)$. Hartman vertelt dan deze 'misdrasj': "There is an interesting midrashic comment to one of the verses dealing with norms of assisting those in need. The next question: 'And if your brother becomes poor and his means fail him with you, then you shall strengthen him, be he a stranger or a settler, he shall live with you' (Lev.25:35). Rashi's commentary to this verse focusses on the clause 'you shall strengthen him": 'Do not let him slip down until he falls completely, for then it will be difficult to raise him; rather strengthen him as he begins to fail. To what is this comparable? To a 
burden upon an ass: while it is still on the ass, one person can hold it and set it in place; if it falls to the earth, even five people cannot set it back". One can understand this midrash as making a commonplace point about the difficulty of assisting a person who has fallen into total poverty. The midrash interprets the meaning of its example by telling the reader: Don't wait for him to fall completely. Who, one may wonder, would wait for him to fall? Given one's willingness to help, would one not need common sense and assist a person when it is easiest - when one person can easily do what five people will have difficulty accomplishing?" (Hartman 1978. $44-45$; zie Onderwijzer, D1. III , 5658/1898, $1977^{3}$, $352-353)$.

Een derde en laatste notitie in dit verband is niet uit de rabbijnse literatuur afkomstig. maar zij betreft een verwijzing naar de situatie van de medische fakulteit in Beer sheva. Israel kent niet het (westerse) onderscheid tussen kerk en staat. De levensordening van de staat Israell is konform de rabbijns-joodse levensordening opgebouwd. Dat dit wel eens spanningen geeft, laat zich raden, maar dat doet hier nu niet terzake. Van belang is dat de diverse instituties en gemeenschappen in Israël verbonden zijn met de joodse traditie, terwijl tevens allerlei westerse verworvenheden in deze instituties en gemeenschappen niet tegenstrijdig aan de halacha behoeven te zijn.

In hetzelfde jaar als in Maastricht - in 1974 - begonnen de eerste studenten in Beer Sheva met hun opleiding tot arts. De twee fakulteiten hebben veel gemeen. Beiden oriënteerden zich uitvoerig in Hamilton (Canada), waar de McMasters University al enkele jaren experimenteerde met een nieuw onderwijsmodel voor het medisch onderwijs. Meer dan elders zijn problemen uit de geneeskundige praktijk invalshoek voor het onderwijs gaan vormen. Beide 
instituten stelden ook de opleiding van artsen voor de eerste lijn c.q. voor de community voorop (Basisfilosofie 1972; Prywes 1972).

De drie belangrijkste doelstellingen van de "Ben Gurion University Medical School" zijn: "The first seeks to develop an integrated program for delivery of preventive, curative and rehabilitative care to the total population of a defined region. The second envisages the merging of this integrated health care system with the University center for Health sciences under a single authority. The third goal is to educate, in this new framework, a different type of physicians whose primary objective will be to provide service in an integrated hospital/community health care system" (Sega11 e.a.1976,112).

De medische fakulteit van Beer sheva heeft een duidelijke verbondenheid met de (regionale) gemeenschap (zie Prywes 1978,6 ). Het leven van deze gemeenschap is geordend volgens de halachische regels van de traditie. Er bestaat geen tegenspraak tussen de medische wetenschap en de medische opleiding enerzijds en de halacha anderzijds. Het is zeer wel mogelijk op moderne, medisch geavanceerde, wijze geneeskunde uit te oefenen en zich als jood te houden aan de halacha zonder dat het om een leven in twee werelden gaat. De traditionele ordening en inspiratie kan ook ordenend en inspirerend werken op de geneeskundige opleiding en praktijkuitoefening. In deze zin $i s$ de rabbijnse literatuur wel aan de orde. Er vindt een synthese plaats tussen het rabbijnse weten van de Torah-traditie en de hedendaagse ontwikkelingen. De traditie vindt hierin har voortgang.

$4 \cdot 4 \cdot 2$. Opvattingen uit de fllosofischjoodse literatuur.

Na de rabbijnse vraagt de filosofisch-joodse 
literatuur onze aandacht. Ik heb mij bij mijn onderzoek beperkt tot de twintigste eeuw. De belangrijkste auteurs $z i j n$ dan Hermann Cohen (1842-1918) met het boek 'Religion der vernunte aus den Quellen des Judentums" "Franz Rosenzweig (1886-1929). Martin Buber (18781965 ) en Emmanuel Levinas (geb. 1906). Voorts gaat het on mensen die aoor een of meerdere van deze filosofen beInvloed zijn.

Alhoewel de vraag naar leven en de levenswerkelijkheid in al zijn facetten aan de orde is, gaan de genoemde auteurs nauwelijks thematisch op vragen met betrekking tot genezen en gezondheid in. Hun inbreng betreft, in beperkte zin en meer im- dan expliciet, medisch-ethische en vooral ook pschotherapeutisch en psychiatrisch relevante kwesties. De belangrijkste auteur in dit verband blijkt Martin Buber te zijn. Ik beperk me in enkele korte notities tot hem.

Van Buber is bekend, dat hij nogal kritisch stond tegenover de psycho-analyse. Met name ook had hij kritiek op het werk van Jung. Vooral de 'religieuze' basis die Jung voorstaat en de wijze waarop hij deze uitwerkt. krijgt Bubers kritiek. De kritiek houdt in, dat Jung in zijn psychologische beschouwingen over de religie zeer onzorgvuldig is en er veel verschijnselen bij betrekt die 'pseudoreligieus' zijn.

De belangrijkste kritiek van Buber betreft Jungs opvattingen over God. "Hij (Jung) ziet Hem in het algemeen als een autonome psychische inhoud - let wel, niet als een zijn of wezen, waaraan een psychische inhoud beantwoordt, mar als juist deze inhoud; als dat niet zo is, voegt hij er aan toe, 'dan is ook God niet werkelijk, want dan grijpt Hij nergens in ons leven in". Dientengevolge zou alles, wat niet zelf een autonome psychische inhoud is, maar een psychische inhoud in ons verwekt of bewerkt of medebewerkt, niet als in ons leven ingrijpend en dus ook niet als werkelijk moeten worden opgevat" (Buber 1954 , 
$\left.1966^{3}, 85-102\right)$.

Jung (h)erkent niet werkelijk de relationele dimensie die, zoals de joodse traditie leert (vgl.Hartman 1978,38-40), de basis van het leven is. Jung kent alleen "'projecties' van de geest", en geen "wezenlijke, de grenzen van het psychische overschrijdende verhouding tussen de individuele ziel en een ander bestaand wezen" (Buber, bij De Bruin 1983,214-215).

Behalve deze polemiek met Jung heeft ook een op de band opgenomen diskussie met Carl Rogers, de auctor intellectualis van de 'clientcentered therapy' een zekere bekendheid gekregen. De bandopname is naderhand gepubliceerd onder de titel 'Dialogue between Martin Buber and Carl Rogers' (Buber/Rogers 1960, 208-211). Het gesprek vond plaats op 18 april 1957 en het makte deel uit van een konferentie over psychiatrie en psychotherapie in Ann Arbor. De nog steeds aktuele en interessante diskussie is onlangs in het Nederlands vertaald en opgenomen in een bundel die handelt over de betekenis van het mensbeeld in de joodse traditie en in de psychotherapie (De Bruin 1983, $237-256$ ).

Van de zes vragen die Carl Rogers en de diskussieleider Maurice Friedman aan Martin Buber stelden, kreeg een vraag van Rogers de meeste aandacht. Rogers veronderstelde dat, wat hij de "effektieve momenten" in de psychotherapeutische relatie noemt - dat wil zeggen de onmiddellijke, gelijkwaardige momenten tussen mensen, datgene wat de relatie waarachtig makkt - overeenkomen met de door Buber uitgewerkte 'Ik-Jij relatie'. Buber antwoordde, dat Rogers dit wel kan denken en willen, max dat dit toch niet het geval is. De therapeut heeft in de hulpverleningssituatie - ook voor de huisarts gaat dit op - een heel andere positie dan de hulpvrager. De therapeut kan iets wat de ander niet kan, terwijl hij dan toch, zoals Rogers wil, op hetzelfde vlak zou staan als de kliënt of patiënt. 
Wat de therapeut denkt te voelen, komt nog niet overeen met de werkelijke situatie. De therapeut kan wel op hetzelfde vlak als de klient willen staan, mar feitelijk is dit niet zo. Aan deze situatie kan de therapeut niets veranderen. De wens van de therapeut verandert de werkelijkheid nog niet. Buber onderscheidt wens en gevoel van de werkelijke situatie.

Buber wil overigens niet Rogers' helpende bezigheid bekritiseren en ook heeft hij geen aanmerkingen op diens methode. Hij aksepteert echter niet dat er sprake zou $z i j n$ van een symuetrische, elkar bevestigende, ik-jij relatie, terwijl Rogers veronderstelde, dat deze op de effektieve momenten in de therapeutische relatie aan de orde zou zijn.

De verdere bijdragen van Buber betreffen allereerst een nogal fundamenteel artikel "Schuld und Schuldgefúhle" (Buber 1958), dat naderhand in een door sborowitz geredigeerde verzamelband over 'personale Psychotherapie in antropologischer sicht' opgenomen is (Sborowitz 1969, 1979\%,106-117;00k in De Bruin 1983, 207-236). Voorts betreft de bijdrage van Buber aan de hulpverlening een inleiding in 'Heilung aus der Begegnung " 3 an Bubers leerling Hans Trüb (Trub 1951,1971, $9-13$ ).

Het artikel 'schuld en schuldgevoelens' is hierom van belang, omdat Buber de door de mens ervaren schuld niet tot het louter psychischgevoelsmatige terugbrengt, mar haar primair met de werkelijkheid in verband brengt. Bubers kritiek op de hulpverleners is, dat deze schuld tezeer interpreteren vanuit de innerlifke schuldbeleving van de mens en dat de werkelijke met schuld beladen gebeurtenissen in het leven van de patiênt te weinig aan de orde komen.

Buber stelt aan de hulpverlener de eis, dat deze zich met zijn hele inzet in de werkelijke levenssamenhangen inleeft, "alsof hij persoon- 
lijk in de situatie van zijn patiënt geraakt is" (Buber, in De Bruin 1983,211). De hulpverlener en ook de patiënt dienen de schuldgevoelens niet in termen van door onduidelijke maatschappelijke bindingen bepaalde "taboes, remmingen en verdrukte verlangens te beredeneren" (id.,211-212), mar de therapeut dient de patiënt te helpen weer daadwerkelijk kiezend en antwoordend in de levenswerkelijkheid te staan. De schuld moet aangepakt worden "als een existentieel gekarakteristeerd iets, dat niet in de ziel, mar in het zijn zetelt" (id. 213).

Van de patiënt verlangt dit een (leren) inzien, dat hij bij zichzelf dient te beginnen, dat hij zijn "trots" 6 oet laten varen (vgl. Rosenzweig $1921,1976^{6}$ ) en moet bekennen en ervaren, dat hij werkelijk persoonlijk schuldig is (Buber, in De Bruin 1983,230-231). Deze "zelfverheldering" is echter niet voldoende. Het vergt ook "volharding" en "verzoening", dat wil zeggen een aktieve opstelling ten opzichte van de eigen persoon alsmede ten opzichte van de betrokken ander(en).

Buber heeft zich zeer kritisch opgesteld tegenover die therapie die alleen op psychische bevrijding uit is. Zij leidt tot een pseudo-verlossing uit het lijden en $z i j$ heeft het gevar in zich, dat de aldus 'genezen' patiênt zich mechanisch gedraagt. De genezing is dan gedachte of gedroomde genezing, maar zij is niet echt verbonden met de werkelijkheid. Het "pijnlijke en vermanende hart" is vervangen door een "apparaat" (id.,218).

Buber is er voorstander van, dat de mens die hulp nodig heeft, geleerd wordt zijn problemen aktief tegemoet te treden en de grond ervan te ontdekken. Hij gat ervan uit, dat problemen niet los staan van de leefsituatie en van de levenswerkelijkheid. Door dit te onderkennen sluit iemand $z i c h$ niet voor zijn problemen af; hij isoleert zich niet, mar blijft in dialoog met de werkelijkheid. Ook vlucht zo lemand niet in allerlei gedachten, fantasieên en 
belevingen, die de aandacht van de werkelijke situatie en van de werkelijke problemen afleiden. Juist dit zou wel eens stress kunnen veroorzaken. Het is de opdracht van de hulpverlener de aan de orde zijnde problemen in het perspektief van de levenssituatie van de betrokken persoon te plaatsen en deze situatie dient werkelijkheid-betrokken te zijn. Vanuit zijn situatie (zie hoofdstuk 5) behoort ook de huisarts hier oor en oog voor te hebben.

Van de 'Leerlingen" van Martin Buber, die op het gebied van de gezondheidszorg werkzaam zijn (geweest), moet ik behalve de hiervoor al genoemde Trüb en Sborowitz, ook Ernst Michel noemen met zijn boek 'Rettung und Erneuerung des personalen Lebens' (Michel 1951). Verder lat in Duitsland met name Rudolf Diepen zich door Buber leiden (Diepen 1961; Buber 1975, 592-593). Ook Viktor von weizsäcker is door Buber beinvloed (Von Weizsäcker $1951^{2}, 25-26$ ). Uit de Verenigde staten tenslotte kan ik nog Leslie Farber noemen (Farber 1963,508-531). Van de overige auteurs, die ik nast Buber noemde, heb ik Franz Rosenzweig reeds uitvoerig besproken in hoofdstuk 2. Rosenzweig heeft zich met gezondheid en genezen als zodanig nauwelijks bezig gehouden. Dit is wel weer het geval met Erich Fromm, die in de twintiger jaren deel uitmaakte van de joodse studiekring rond Franz Rosenzweig. In het zesde hoofdstuk kom ik nog op From terug.

Een andere al genoemde auteur, Emmanuel Levinas, heeft zich evenmin als Rosenzweig rechtstreeks met gezondheid en genezing bezig gehouden. zijn werk en zeggingskracht is echter nog onvoldoende doorgedrongen en uitgekristalliseerd on nu al te kunnen zeggen, in hoeverre hij voor de gezondheidszorg betekenis kan hebben. Van direkt belang reeds is een studie van Burggraeve, die in zijn boek "Van zelfontplooilng nar verantwoordelijkheid" een synthese zoekt tussen het psychoanalytisch mensmodel van Freud-Lacan en de ethische visie 
van Levinas. Ik acht deze studie van groot belang, omdat hierin het strikt filosofisch denken van Levinas verbonden wordt met een andere, belangrijke zaak, namelijk aie van de psychiatrie en van het psychisch gezond bestaan. Het is Burggraeve niet geheel gelukt een synthese tot stand te brengen. Het is Burggraeve daarentegen wël gelukt een inzicht te geven in de aan de orde zijnde vraagstukken. Niet de van de werkelijkheid gersoleerde zelfontplooiing is gezond menselijk leven zij is narcistisch van aard - maar de op de werkelijkheid betrokken verantwoordelijkheid door en voor de ander, die tot stand komt in "de epifanie van het gelaat" (Burggraeve 1981).

4.5. Enkele aantekeningen.

De levensordening van Israël in de tijd van Bijbel en Talmoed was gericht op de Torah en op een leven naar de Torah. "Extending to all. details of life, the Torah became the means for establishing the supremacy of the will of God as the measure of all directions and strivings of the human heart. All the common ways of life, all political, social, cultural and domestic interests come under its rule (...), the Torah discipline penetrates every moment in the life of the Jew, to strengthen him not only in the service of God, but also to bring all human occupations into relation with the will of God. Given this accord, the will of God is no longer something other than, or opposed to, man's real nature, but is man's real nature" (Epstein,1954,1980 2 ,288). zoals ik in het eerste deel van dit hoofdstuk heb aangetoond, staan ook gezondheid en genezen in verband met (de opdracht van) de Torah. Studie van en leven nat de Torah wordt als een gezonde en helende wijze van leven gezien. Israël heeft $z i c h$ hiermee duidelijk van de 
andere volkeren onderscheiden. Uit de dienstbaarheid aan Egypte bevrijdde het zich tot een op de mens en de wereld betrokken dienstbaarheid a an de Fne God. Vervolgens werden de afgodendiensten van Kanaän en Babylon - de mannelijke Baäl en de vrouwelijke Astarte ten diepste verfoeid. ook ten aanzien van de Griekse goden- en helden-kultuur bleef de Torah-traditie zich als een geheel eigen traditie onderscheiden. Dit latste is van belang, omdat de geschiedenis van de westerse geneeskunde teruggat tot de Griekse.

Hippokrates (ca.460-ca.377 v.Chr.) wordt wel de vader van de geneeskunde genoemd. Van hem is bekend, dat hij een zeer hoge persoonlijke taakopvatting kende, gericht op feitelijke observatie (Van der Hoeven 1963). Het voert te ver hier een vergelijking te maken tussen de Griekse geneeskunde, met name die van Hippokrates, en de geneeskunde van het oude Israël. Ongetwijfeld zullen er naast een verschil in geesteshouding ook vele overeenkomsten zijn. Van belang is, dat Hippokrates het ziek zijn niet langer toeschrijft aan mythische en demonische invloeden, maar dat hij de oorzaak zoekt in verstoorde, fysiologische samenhangen van het Iichaam.

Het optreden van Hippokrates moeten we platsen in de bloeitijd van Hellas (Van der Hoeven 1963:00k Ten Have 1982,106-115). De Griekse beeldhouwkunst en het Griekse denken stonden toen op een hoogtepunt. De hoge esthetische waarde van het 1 ichaam werd vooropgesteld en hier ligt de basis voor de hoge taakopvatting van de Griekse arts.

De joodse geleerden en artsen hebben dit principe niet als een eerste beginsel overgenomen. Wel is, met name in de Middeleeuwen, een synthese tussen het Griekse en Hebreeuwse denken tot stand gekomen, maar steeds bleef de Torah voorop staan.

Toen op het eind van de achttiende eeuw de 
joodse burgers in de diverse landen van Europa dezelfde rechten kregen als de andere inwoners, begonnen zij op grote schaal deel te nemen aan het Europese (en later ook Amerikaanse) geestes- en kultuurleven. Dat hield onder andere in dat zij medicijnen konden gaan studeren en ook wetenschap konden gaan beoefenen. Veel joden hebben sindsdien een bijdrage geleverd aan de ontwikkeling van de moderne natuurwetenschappelijke geneeskunde (Enc.Jud., Vol.11, 1195-1211). Het eigen joodse erfgoed verdween in dit proces van assimilatie naar de achtergrond.

De opkomst van de medische wetenschap betekende voor de rabbijnen, dat zij er niet onderuit konden de moderne ontwikkelingen te toetsen aan de Torah. Dit proces is vooral in onze eeuw tot ontwikkeling gekomen. In het laatste deel van dit hoofdstuk heb ik een korte verwijzing gegeven naar de joodse medische halacha. In hoofdstuk $6(6.3)$ ga ik hierop verder in.

De openheid van de moderne tijd en de assimilatie van veel joden brachten, zoals gezegd, Franz Rosenzweig en Martin Buber tot het besef, dat de oude joodse woorden niet mochten verdwijnen. Beiden hebben geprobeerd tot een synthese tussen het Grieks-Europese en het joodse denken te komen. Dit zien we ook bij Heschel en Hartman, de beide auteurs naar wie ik een korte verwijzing gegeven heb.

De joodse geleerde Achad Ha-Am (= Eén van het Volk: pseudoniem van Ascher Hirsch Ginsberg. 1856-1927) - die evenals de hiervoor genoemde auteur Hartman door Maimonides beInvloed is schreef eens dat er twee vormen van assimilatie zijn. De ene vorm is die waarin je je eigen identiteit ontkent. Je zegt dan, dat je geen jood (meer) bent, maar bijvoorbeeld Europeaan, Christen, Nederlander, Fransman, Duitser. Achad Ha-Am noemt dit de assimilatie van de zelfvernietiging. De tweede vorm stelt niet de vraag waarom men jood is of jood moet blijven. Jood zijn is een gegeven en je aksep- 
teert wie je bent. Assimilatie houdt dan in. dat men het andere, nieuwe en/of vreemde opneemt en verwerkt zonder de eigen identiteit te verliezen. Dit noemt Achad Ha-Am de gezonde en vruchtbare vorm van assimilatie (zie ook Enc.Jud. , Vol . 2, 440-448).

Zo kan men van een vruchtbare assimilatie spreken als de naar de Torah levende arts verworvenheden uit de westerse geneeskunde konform de richtlijnen van de halacha integreert in zijn leef-en werksituatie. In de Middeleeuwen was het werk van Maimonides een voorbeeld van een dergelijke vruchtbare assimilatie. In onze tijd gat dit op voor de hiervoor genoemde auteurs Hartman en Heschel en voor de eerder genoemde filosofisch-joodse denkers Buber, Levinas en Rosenzweig. Rosenzweig nam zijn tijd en de situatie waarin hij leefde, ernstig en kwam zo tot zijn "Neues Denken" en "Neues Lernen". Men kan, tenslotte, ook van een vruchtbare assimilatie spreken als de niet-jood de Torah-traditie, met behoud van zijn eigen niet-jood zijn, wil leren kennen en integreert in zijn bestan. 
HOOFDSTUK 5: ENKELE HUISARTSGENEESKUNDIGE KONSEPTEN NADER GEINTERPRETEERD VANUIT HET JOODSE WETEN.

5.1 . Inleiding.

$5 \cdot 1 \cdot 1$. Een "nieuw leren' : vanuit onze situatie naar de joodse traditie.

In de voorafgaande hoofdstukken heb ik geprobeerd aan te tonen, dat het joodse weten een bijdrage kan leveren en een perspektief kan geven aan onze levensoriëntatie en dat zij al-dus het gezond mens $z i j n$ in de meest omvattende zin kan bevorderen. Verder heb ik er een beeld van gegeven hoe door de eeuwen heen in de joodse traditie de genees- en gezondheidkundige opvattingen gestalte hebben gekregen. In dit hoofdstuk wil ik trachten enkele konsepten uit de huisartsgeneeskunde naast opvattingen uit de joodse traditie te leggen.

Rosenzweig en Levinas hebben erop gewezen, dat in onze tijd en kultuur een terugkeer naar het rabbijnse jodendom van Torah en Talmoed niet zonder meer mogelijk is. Het betreft een voor velen onbekend terrein. Niet iedereen ook kan of wil deze ommekeer maken. De invloed van de christelijk-humanistische kultuur is daarvoor te belangrijk en de westerse kultuur heeft een eigen-waarde waaraan niet kan worden voorbijgegaan.

In een tijd van heroriëntatie - "het begin van een nieuw tijdperk in de geschiedenis" (Sperna Weiland $\left.1966,1972^{\circ}, 25\right)$ - kan het van belang zijn wetenschappelijke en handelingskonsepten uit de westerse traditie te relateren aan relevante inzichten uit de joodse traditie. Dit sluit aan bij wat ik. in de inleiding zei over 
de joodse achtergronden van onze westerse kultuur. Het is deze wijze van studeren die Rosenzweig een 'Neues Lernen' noemde (Rosenzweig $1937,96-97)$.

In de beward gebleven ontwerp-openingsrede voor het joodse leerhuis in Frankfurt am Main schreef Rosenzweig over dit nieuwe leren dit: "Es entsteht, nein, es ist entstanden, ein neues Lernen. Ein Lernen In umgekehrter Richtung. Ein Lernen nicht mehr aus der Tora ins Leben hinein, sondern umgekehrt, aus dem Leben, aus einer welt, die vom Gesetz nichts weiss oder sich nichts wissen macht, zurück in die Torah, Das ist die signatur der zeit" (id.,1937,96-97). En hij vervolgt: "Die Signatur der zeit, weil es die Signatur der Menschen der zeit ist. Es ist heut keiner, der nicht entfremdet ist, oder der nicht wenigstens ein Stück Entfremdung in sich hat (...). Wir alle, soweit uns das Judentum, das Judesein wieder die zentrale Tatsache unsres Lebens geworden ist - und ich weiss, dass ich hier nicht fir mich allein spreche - wir alle wissen, dass wir unserm Judesein zwar alles opfern missen, aber nichts opfern dirfen. Nichts preisgeben, nichts verleugnen, aber alles zum Jüdischen zurückführen. Von der Peripherie ins Zentrum zurick, vom Aussen ins Innen" (id..97). Voor hem betekende dit terug naar het joodse leven en vooral terug naar het joodse leren.

Met zijn "Neues Lernen' stond Rosenzweig overigens geen nieuwe methode voor. Het aloude joodse (leven), de joodse traditie, bleef zijn methode $(1 \mathrm{~d} .1935,407 ; \mathrm{id} ., \mathrm{Bd} .2,1979,720)$. Wel bedoelde hij met een nieuw leren een leren dat aan de situatie van vandaag de dag is aangepast. De oude leervormen voldoen niet meer, mar dit wil niet zeggen dat leren van de Torah en hat traditie niet meer van betekenis zijn. Dit is wel degelijk het geval, maar er doen zich nu eenmal steeds andere situaties voor. Rosenzweig wil juist dat de aktualiteit 
van het moment, de situatie zoals ze nu is, tot vertrekpunt voor het (nieuwe) leren wordt opgenomen.

Van dit leren in omgekeerde richting, waarbij niet de joodse inzichten tot vertrekpunt genomen worden, maar de situatie en opvattingen van onze tijd, wil ik in dit hoofdstuk iets laten zien. Ik makk hierbij een keuze uit enkele met betrekking tot de huisartsgeneeskunde belangrijke konsepten, om vervolgens enkele terzake relevante opvattingen uit de joodse traditie ernaast te leggen.

$5 \cdot 1 \cdot 2$ Huisartsgeneeskunde en enkele van haar basisopvattingen.

Veel levens- en gezondheidsklachten komen in eerste instantie bij de huisarts terecht. En uit de literatuur blijkt dat de huisarts hiervoor ook beschikbaar wil zijn, althans theoretisch en als ideaal. De huisarts werkt in een positie waarin hij met iemands persoon en levensloop gekonfronteerd kan worden en waarin hij kennis kan nemen van de leefsituatie van zijn patiënten. De verwevenheid van lichamelijke, psychische en sociale faktoren in het licht van de levensgeschiedenis van de mensen geeft aan de huisartsgeneeskunde een bijzonder karakter, wat er toe leidt, dat de huisarts een geheel eigen klacht- en probleembenadering voorstaat. "De huisarts wét, op grond van directe contact(en) met de omstandigheden en de persoon, dat achter ledere klacht een verhal verborgen ligt" (Bergsma, 1981, 3).

Dit wil nog niet zeggen dat de huisarts zichzelf geen vragen stelt en geen twijfel kent met betrekking tot zijn funktioneren en taak. Volgens het auteursduo 'Breung' vraagt de huisarts zich dagelijks af warmee hij zich eigenlijk bezig houdt: met somatische problemen of met problemen van matschappelijke, sociale, psychische, geestelijke en existentiéle 
aard (Breung 1980,62). Of met belde, in een dan nader te onderzoeken samenhang, zo meen ik hieraan toe te moeten voegen. Het voorgaande howdt ook niet in, dat de huisarts altijd werkelijk doet wat hij (in de literatuur) voorstaat. Ik memoreerde in hoofdstuk 1 al het onderzoek van Boots (Bobts 1983).

In de eerste jaren na de tweede wereldoorlog werd de huisarts al spoedig met twee problemen gekonfronteerd. Door de groeiende medischtechnische mogelijkheden die vooral in institutioneel verband door steeds meer specialisten werden toegepast, bleef de huisartsgeneeskunde relatief achter, ofschoon het bezoek aan de huisarts toenam. Vooral de lichtere aandoeningen kwamen nog bij de huisarts terecht (Ruhe 1957,38$)$. Tegelijk echter werd de huisarts in toenemende mate aangesproken door de sociale en psychische nood van zijjn patiënten. In deze situatie ging de huisarts zich opnieuw bezinnen op zijn tak en funktie.

Een van de eersten die zich met het werk van de huisarts ging bezig houden was Buma (Buma 1950). Buma registreerde in zijn studie, dat een percentage van $28 \%$ van de problemen die hij tegenkwam, gerekend moet worden tot wat hij "sociale problemen" noemde. Ook vond hij een zeer grote groep (in een percentage uitgedrukt: $32 \%$ ) van aandoeningen, die hij niet bij de klassieke ziektekundige syndromen kon onderbrengen. Buma sprak van "symptomatische aandoeningen". Deze hebben betrekking op patiënten die "in het een of ander opzicht niet kunnen voldoen aan de eisen die het leven hun stelt". Dit is de situatie warmee de huisarts steeds meer te maken kreeg. "Om deze grote en belangrijke groep patiënten te beoordelen en te begrijpen is nodig" "zegt Buma dan, "een in het anthropologisch denken geschoolde huisarts" (Buma 1950,161-164).

Dertig jaar nadien gaat het hier mijns inziens nog steeds om een zaak van belang. De mensen klagen veel over "onwelbevinden". Op grote 
schaal, zo zegt Van Es, komt de huisarts in aanraking met wat momenteel "probleemgedrag" genoemd wordt. Aan onwelbewinden kan ziekte ten grondslag liggen. De omgang met dit onwelbevinden rond een wel of niet reele ziekte noemen we ziektegedrag. Bij probleemgedrag is sprake van problemen die niet direkt op ziekte betrekking hebben. Te denken valt dan aan intrapersoonlijke problemen, aan relatieproblemen en aan arbeidsproblemen (Van Es 1980,5861). Bergsma ziet op grond van onderzoek het patroon, dat veel vragen aan de huisarts niet met "ziekte" als zodanig te maken hebben, bevestigd (Bergsma 1981,5). Van de huisarts mag, zo stelt Van Es, verwacht worden, dat hij "inzicht moet hebben in het probleemgedrag van patiënten". Bovendien betitelt hij het als "nuttig", dat de huisarts zich verdiept in de verdere achtergrond van het probleemgedrag (Van Es 1980,59-63).

Er zijn hier belangrijke zaken aan de orde. Ziektegedrag en probleemgedrag duiden er niet alleen op, dat de menselijke heelheid in het geding is, maar ook dat, voorzover er niet echt van ziekte sprake is, de gezondheid van de mens desondanks wordt bedreigd. Van Es noemt een aantal aspekten, die met probleemgedrag te maken hebben en die de gezondheid bedreigen: "het razende tempo warin veranderingen op allerlei gebied zich voltrekken, de problematische arbeids-, gezins- en huwelijkssituaties, het niet meer deel uitmaken van een buurt of gemeenschap, het probleem van de schalvergroting en ook het grote skala van riskante leefgewoonten" (id.,77-78).

Van de huisarts van de toekomst - "de anthropologisch geschoolde huisarts" - verwachtte Buma dat deze het in de geneeskunde gebruikelijke begrip "diagnose" zou gaan vervangen door "een beschrijving van de gezondheidstoestand van een individu". Buma noemde deze diagnose die het geheel der levensomstandigheden in ogenschouw zou moeten nemen, een "anthropologische diagnose" (Buma 1950,102; 
vgl.van Es 1980,185-186). De arts dient - ook als er van een somatische aandoening sprake is - niet alleen na te gaan wat de aard van het ziek zijn is en hoe deze aandoening tot stand gekomen is. mat hij dient ook na te gaan warom deze patient ziek is en warom hij juist op deze wijze ziek (geworden) is. Als de arts zijn patiënt "als mens" tegemoet wil treden, kan hij hier niet onderuit, aldus Buma (id. .70).

Intussen zijn veel van Buma's inzichten gemeengoed geworden. De huisarts neemt in meerdere of mindere mate de integrale benadering tot uitgangspunt, waarbij hij niet alleen de somatische, maar ook de psychosociale aspekten bij zijn werk betrekt (zie o.a. Brouwer 1962). In veel situaties heeft dit geleid tot de oprichting van gezondheidscentra en van andere vormen van samenwerking (zie 'Hoe helpt de dokter?" 1975; zie voor de ervaringen met een gezondheidscentrum: Riphagen 1981). Ook neemt de huisarts betreffende ziekte en gezondheid in wetenschap en praktijk het gezinsfunktioneren tot richtsnoer (Huygen 1978) en/of de levensloop van de mens (Medalie 1978; Van Es $1980,217-279)$.

De huisarts heeft verder een eigen wijze van werken ontwikkeld (zie 'Hoe helpt de dokter?' 1975: 'De taken van de huisarts' 1977; HoltenVriesema e.a. 1978, Van Aalderen e.a. 1982) en hij bezint zich sinds de 'Woudschotenkonferentie' in 1959 op zijn taak en funktie (zie 'Woudschotenrapport' z.j.;'De plaats van de medikus in het eerste echelon' 1976:'De funktieomschrijving van de huisarts' 1981; 'Basistakenpakket van de huisarts' 1983). In 1956 werd een wetenschappelijke organisatie voor huisartsen gesticht, het Nederlands Huisartsen Genootschap. In 1965 werd het Nederlands Huisartsen Instituut opgericht. De eerste hoogleraar huisartsgeneeskunde werd in 1967 in Utrecht benoemd, in het begin van de jaren zeventig gevolgd door benoemingen elders. In de- 
ze jaren ook werd een begin gemakt met de beroepsopleiding tot huisarts.

ook in het buitenland heeft in vele landen een herwardering c.q. opwaardering van de huisartsgeneeskunde plaats gevonden. Ik denk aan Australiè, België, Canada, Engeland, Frankrijk, Hongarije, Isrä̈l, Joegoslavië (waar in 1961 in Zagreb de eerste beroepsopleiding tot huisarts begonnen werd), Oostenrijk, de Verenigde staten, West-Duitsland, zuid-Afrika en de Skandinavische landen. Ik moet hierbij overigens wel aantekenen, dat in sommige landen, meer dan in Nederland, de gerichtheid van werken van de huisarts medisch-somatisch is en dat daar ook de opleiding tot huisarts een sterk klinisch karakter heeft (zie o.a. Medalie 1978; Fry 1980).

Van belang is voorts, dat in de huisartsgeneeskunde gewerkt wordt aan een wijze van verslaglegging warin plaats is voor niet-somatische aspekten en warbij ook de subjektieve gegeveris, zowel die op de patiënt als op de arts betrekking hebben, verwerkt worden (van der Horst e.a. 1 en 2, 1981). Deze wijze van verslaglegging veronderstelt, dat de genoemde aspekten in het hulpverlenend handelen dan ook verhelderd worden.

Tenslotte is nog een belangrijke ontwikkeling in de huisartsgeneeskunde, dat "de kloof die gaapt tussen het probleern van de patiënt (de klacht) en de interpretatie die de huisarts hiervan geeft (de diagnose)" onderkend wordt. sinds 1978 wordt in internationaal verband een klassifikatie van redenen om naar de huisarts te gaan ontwikkeld. Deze 'Reason for encounter classification (RFEC)' staat geheel op zichzelf, dat wil zeggen de diagnose blijft principieel buiten beschouwing. Central staat de probleemverheldering, niet de probleeminterpretatie van de huisarts. Het projekt bevindt zich nog in een experimenteel stadium (Lamberts $1982,301-310)$. Het wetenschappelijk belang van dit onderzoek ligt vooral in de realisatie van een voor de huisartsgeneeskunde 
geschikt klassifikatiesysteem.

De ervaringen uit de algemene praktijk hebben de huisarts geleerd, dat in meerdere of mindere mate aan iedere aandoening een "antropologisch" probleem ten grondslag ligt (Buma 1950, 228). De huisartsgeneeskunde is op het appèI dat 'de mensen geen leven hebben' (Weijel 1970) ingegaan. De huisartsgeneeskunde houdt zich niet alleen met 'ziekten' bezig, maar zij is gericht op het in stand houden en bevorderen van de gezondheid in de meest brede $z i n$. Bovendien weet de huisarts dat ziek zijn ook altijd een existentielle krisis inhoudt, merkt Dokter op (Dokter 1973). De huisarts is hierdoor niet alleen geneeskundige, maar ook 'antropoloog" en 'gezondheidkundige' .

Dit behoeft geen afbreuk te doen aan de grote verdiensten van de natuurwetenschappelijke, medisch-technische en medisch-somatische geneeskunde (vg1.Buma 1980,88), maar deze worden door de antropologisch-gezondheidkundige richtingbepaling in de kontekst van de mens en diens situatie geplaatst. "De huisarts brengt de duurzame relatie met zijn patiënten a prio$r i$ onder in een verhouding, waarin patiëntzijn meer is dan een kwestie van ziek-zijn of niet ziek-zijn. Het is een verhouding waarin de basale zorg wordt onderworpen aan de intentle van de huisarts het patiënt-zijn naar warheid te beantwoorden, de patiënt als mens tot zijn recht te laten komen en zo het vertrouwen van de patiënt waardig te zijn" (De Geus 1973,254 ).

Tegen de achtergrond van de Funktieomschrijving uit 1981 en het Basistakenpakket uit 1983 beschrijft De Geus de positie van de huisarts - ideaal gezien - als volgt: "De huisartsen bieden, als personen en collektief, zorg aan die:

- direkt, permanent en vrij toegankelijk is;

- gesitueerd is in de nabijheid van degenen die de zorg behoeven; 
- gericht is op mensen in hun leefmilieu. Huisartsenhulp is in dit aanbod zonodig altijd en zonder uitstel beschikbaar. Er is geen drempel en de afstand hoeft niet groter te zijn dan die tot het eigen telefoontoestel of een pand in de buurt.

De huisarts is bekend met dezelfde leefgemeenschap als de patiënt: als stads-, dorps- of buurtgenoten leven beiden in eenzelfde ekologisch en sociaal milieu. Daarbinnen heeft de huisarts door zijn funktie toegang tot het privé-domein van $\mathrm{zijn}$ patiënten.

Dat schept de mogelijkheid opvattingen, ongevingscondities en levenssfeer te betrekken in de zorg, die gevraagd en verleend wordt.

Patiënt en arts ontmoeten elkaar op eigen terrein, mar er is meer. Met het oog op de zorg is er een persoons- en veelal gezinsgebonden relatie voor onbepalde tijd tussen beiden. In die relatie neemt de huisarts deel an het leven van velen, leert hij hen kennen en begrijpen. Dat is van onschatbare waarde, telkens wanneer zijn hulp nodig is. (...).

Binnen het systeem van gezondheidszorgvoorzieningen is de huisarts de geneeskundige van de eerste lijn of frontlinie. In principe stat hij voor alle vragen om hulp open.

zijn medische deskundigheid is richtinggevend voor de wijze warop hij op deze vragen ingaat.

In korte trekken is hiermee de positie van de huisarts getekend. Daaraan ontlenen zijn rol, zijn taakvervulling en dus ook het huisartsgew neeskundig handelen specifieke kenmerken" (De Geus 1983, II/1-1 en 1-2).

Het konsept van de hedendaagse huisartsgeneeskunde bevat een aantal kenmerken of elementen, die steeds weer naar voren komen, merken de auteurs van het tweede rapport 'Kenmerken van de huisarts' op. Zij noemen dan de volgende drie (die ik hier kort samenvat):

- De huisarts is werkzaam in de eerste linie van de gezondheidszorg. 
- De huisarts biedt een kontinue zorg aan die patiënten die regelmatig hulp of begeleiding nodig hebben.

- De hulpverlening van de hulsarts speelt zich af in een persoonlijke, duale relatie met de hulpzoekende, warin de levensgeschiedenis van de hulpzoekende steeds de kontekst vormt zowel van klachten en symptomen als van de hulpverlening, naast de inbedding in het gezin of een andere primaire groep (Van Es e.a. $1983,7-9)$.

Uit de hier genoemde elementen destilleren Van Es c.s. een aantal konsekwenties voor het funktioneren van de huisarts:

"- In de eerste plaats zal de huisarts in staat moeten zijn hulp te bieden bij patiênten met funktionele en psychosomatische aandoeningen. (...).

- In de tweede plaats zal de huisarts qua kennis en vaardigheden goed moeten worden toegerust om tal van lijden aan lichamelijke ziekten, in het bijzonder de veel voorkomende, goed te kunnen behandelen en begeleiden. (...)" (id.,11).

"Samenvattend zijn wij van oordeel", zeggen de auteurs, "dat de grondslag van het werk van de huisarts ligt in een duale, continue, integrale relatie van patiënt en huisarts, warin ook de levensloop van de patiënt tot uiting komt. Binnen deze relatie moet de arts een verantwoord handelend, medisch deskundige zijn, die tot $z i j n$ handelen mede besluit op grond van zijn voorkennis van de persoon, de voorgeschiedenis en het milieu van de hulpzoekende" (id., 11).

Hierbij moet ik een aantekening maken. Onderzoek heeft namelijk aangetoond, dat het funktioneren van de huisarts in de praktijk niet altijd in overeenstemming is met hetgeen de literatur op het gebied van de huisartsgeneeskunde ons voorhoudt. Ik stelde dat hiervoor ook al aan de orde. De bedoelde diskrepantie komt naar voren in de wijze warop de huisarts zijn tijd besteedt in relatie tot de 
opvattingen die hij hierover heeft (Boots 1983), maar betreft ook een diskrepantie tussen de arts die "objektieve feiten" wil vaststellen en de patiënt die met een geheel eigen "subjektieve werkelijkheid" aanwezig is; met andere woorden: er bestaat een onderscheid tussen "het benoemingsproces van de arts" en "de biografie van de patiënt" (Kimsma en Ten Have 1984).

De belangrijkste inhoudelijke kenmerken $c . q$. benaderingswijzen van de huisarts zijn volgens Van Es: de levensloopgeneeskunde, de integrale benadering en gezinsgeneeskunde (Van Es 1980", 24-26;id., 217-279; Van Es e.a. 1983,23-28). Deze inhoudelijke kenmerken vormen als zodanig niet de basis van het huisartsgeneeskundig handelen. Huisartsgeneeskunde is niet een synthese van integrale, gezins- en levensloopgeneeskunde, maar in de persoonlijke geneeskunde van de huisarts spelen de genoemde konsepten een belangrijke rol. De persoonlijke zorg van de huisarts - de op 'leven' gerichte verantwoordelijkheid van de een voor de ander (zie hoofdstuk 6) - krijgt op een bepaalde wijze gestalte. De omschrijving hiervan vinden we in de genoemde konsepten.

Op twee van deze konsepten, namelijk de integrale benadering en de levensloopgeneeskunde ga ik verder in, waarbij ik zal proberen de woorden integraal en levensloop te interpreteren en te verdiepen vanuit hetgeen de joodse traditie in deze te zeggen heeft.

5.2 . Integrale geneeskunde en de betekenis van de woorden 'integer' en integriteit' in het joodse weten. 
Het konsept van de integrale geneeskunde is van grote invloed geweest op de ontwikkeling van de na-oorlogse huisartsgeneeskunde. De basis van dit konsept ligt in de opvatting, dat met betrekking tot de zieke mens een drietal aspekten of "betrekkingsvelden" (Trimbos 1976, 65) te onderscheiden zijn "waarbinnen verstoringen van evenwicht kunnen optreden" (id.). Het gaat hierbij om een biologisch (ook aangeduid als het fysische of somatische), een psychisch (geestelijke) en een sociaal (maatschappelijk) aspekt. Door de integratie van deze aspekten in de benadering van een patiënt c.q. In de diagnose en therapie, tracht de geneeskunde het ldeal van de mens als ondeelbare eenheid (weer) te bevorderen.

In 1950 sprak Buma in dit verband van 'antropologie". Hij bedoelde hiermee "de gecombineerde studie der somatische, psychische en sociale funkties van de mens" (Buma 1950, 105). Buma pleitte ervoor, dat de geneeskunde antropologisch van karakter zou zijn, zij behoorde: "haar belangstelling gelijkelijk te verdelen over de somatische, de psychische en de sociale zijden van het mens-zijn" (id.). Buma had hierbij vooral voor de huisartsgeneeskunde een taak op het oog. Zijn inzichten waren gebaseerd op ervaringen in de huisartspraktijk.

Het woord antropologische geneeskunde is gelieerd aan von Weizsäckers opvattingen over wat hij de 'medizinische Anthropologie' noemde. Von Weizsăcker, die bevriend was met Martin Buber en Franz Rosenzweig, bedoelde met zijn geneeskundige antropologie die vorm van geneeskunde, warin de mens (weer) als subjekt, als persoon en medemens, tegemoet getreden wordt en warin bovendien de situatie van de mens in diens kultuurhistorische, sociale en metafysisch-existentiële kontekst betrokken wordt (zie Von Weizsäcker 1949,35-179; Hartmann 1973,78; Van der Hoeven $1965,28-43$ ). Bij Buma is deze 'diepte'dimensie minder aan de orde. 
De term antropologische geneeskunde werd geen gemeengoed in Nederland. Toch vond Buma's konsept ingang. Een belangrijke stimulans hiertoe vormde het boek van Querido: "Inleiding fot een integrale geneeskunde' $\left(1955,1973^{2}\right)$. Querido noemt de integrale geneeskunde het specialisme van de algemeen arts (id.,248). Het is, zo zegt hij, met name de huisarts die gekonfronteerd wordt met de mens als eenheid. "De mens is een eenheid - de patiënt is een persoon - dit zijn geen lege leuzen, die alleen met de lippen beleden kunnen worden" (id.). Het isoleren van bepaalde onderdelen of facetten noemt Querido een hulpkonstruktie en alleen als zodanig is deze konstruktie geoorloofd. "De geneeskunde is gericht op de mens en de mens is een ondeelbare eenheid" (id.,1). Querido memoreert dat de geneeskunde zich tot nu toe vooral met fysische en biologische oorzaken van ziekten heeft bezig gehouden. De oorzaken die liggen in "de psychosociale struktuur van de mens" en in "het sociaal milieu" hebben tot nu toe onvoldoende aandacht gekregen $(i d ., 2)$. Het konsept van de integrale geneeskunde moet men zien tegen de achtergrond van "een behoefte aan synthetisatie van datgene wat orgaangeneeskunde en laboratoria hebben geanalyseerd" (id.,3). Querido adviseert om de onderlinge samenhang van de somatische, psychische en sociale facetten na te gaan, teneinde langs die weg tot een totalibeeld met betrekking tot de mens en zijn ziekte, c.q. de zieke mens te komen $(i d ., 3)$.

op de reeds genoemde konferentie in woudschoten in 1959 werd het konsept van de integrale geneeskunde als een belangrijk uitgangspunt van het huisartsgeneeskundig handelen aanvaard. Het ging niet alleen een belangrijke rol spelen in de huisarts-patiëntrelatie, maar ook diende het als onderbouw voor multidisciplinaire samenwerking in de eerste lijn (zie o.a. het rapport 'Hoe helpt de dokter' 1975). Overigens zijn de hoge verwachtingen die aanvankelijk aan de integ-ale geneeskunde gesteld 
werden, niet uitgekomen. In 1974 konstateerde De Geus, dat zij niet langer een aanbod van de individuele arts kon zijn (De Geus 1974,2538). Trimbos zou graag zien, dat het wel haalbare, namelijk "een goed gecoördineerde geneeskunde en gezondheidszorg" " hetgeen "teamwork" inhoudt, verwerkelijkt zou worden (Trimbos 1976). Menges noemt de "integrale arts" een weinig reele zaak. "Hoewel de huisarts dit nieuwe type arts nog het dichtst zou kunnen benaderen, kan ook van hem onmogelijk worden gevraagd dat hij in letterlijke zin integraaldeskundig én vaardig is. Tegen de achtergrond van hedendaagse inzichten zou hij dan een kombinatie van medicus, psycholoog en matschappelijk werker moeten zijn, iemand die een redelijke kennis van uiteenlopende psychologische en sociologische visies part an vardigheden op terreinen als de individuele psychotherapie, gezins-, echtpaar- en groepstherapie, situationele interventies en andere terreinen van begeleiding en zorg. Dit beeld van de arts als duizendpoot moet worden verworpen, in de eerste plaats reeds omdat we aan de gezondheid van de arts zelf moeten denken" (Menges 1980,84). Menges noemt de interdisciplinaire samenwerking wel een basisvoorwaarde voor de ontwikkeling van de integrale geneeskunde (id.,85).

Samenvattend zou ik willen zeggen dat het konsept van de integrale geneeskunde in de huisartspraktijk - als ideaal - vrij algemeen ingang gevonden heeft. "Dit houdt in dat hij (de huisats) zodanig hulp verleent, dat lichamelijke, geestelijke en sociale faktoren in hun onderlinge verband worden gezien. Zuiver matschappelijke of psychologische hulp biedt hij dus niet" (Van Es e.a. 1981,11). De huisarts biedt in deze zin geen integrale geneeskunde of zorg. Wel is zijn benadering integraal. In het verband van een samenwerkend team kan overigens wel een aanzet tot integrale zorg gegeven worden. 
Het woord 'integraal' behoeft verdere toelichting. Verbonden met geneeskunde of de dito zorg $c . q$. benadering heeft integraal vooral betrekking op een diversiteit van aspekten, waarbij wordt beoogd, in de wisselwerking en samenhang ervan, de mens als geheel te benaderen en waarbij de arts integrerend werkzaam is. "De integrale geneeskunde (in het Engels 'comprehensive medicine') makt als het ware een aantal dwarsdoorsneden, warin het lichamelijke, het geestelijke en het matschappelijke in hun onderlinge relatie zichtbaar worden. In de integrale geneeskunde staat juist deze wisselwerking in het centrum van de aandacht" (Van Es 1980',233).

Spreeuwenberg vermeldt dat het woord integraal op twee te onderscheiden zaken betrekking kan hebben: "Ten eerste dat iets heel, volledig en ongedeeld is. Ten tweede dat een aantal delen zodanig zijn samengevoegd, dat er zowel sprake is van een "kwalitatief plus' als van het herkenbaar zijn van de oorspronkelijke eenheden in de uiteindelijke heelheid" (Spreeuwenberg $1982,89)$. Met name de eerste betekenis van het woord 'integraal' is nog onvoldoende doordacht.

Als we naar de betekenis van het woord kijken heeft integraal in eerste instantie de betekenis van: "op zichzelf bestaand", "een geheel. uitmakend". Voorts betekent het: "waraan niets ontbreekt", "alles omvattend", "in zijn gehegl", "volledig" (De Grote Oosthoek, d1.10, $1978,276)$. 'Integraal' stant af van het latijnse woord 'integer' dat, zo vermeldt het woordenboek, 'in materielle zin' de betekenis heeft van "gaaf", "in zijn geheel", "volledig". "ongedeerd" en "in psychische en morele zin" van "onbeslist" "onuitgemaakt", "nog vrij staand". Ook spreeuwenberg en voorts onder andere Fortmann vermelden dat het adjektief integraal afstamt van het latijnse 'integer', dat, zo zegt Fortmann, oorspronkelijk "onaangetast" betekent (Spreeuwenberg 1982,89; Fortmann $1968,1974^{2}, 311$ ). 
Als we integraal in de betekenis van "heel, volledig en ongedeerd" gebruiken - de eerste door spreeuwenberg onderscheiden betekenis staat het nog het dichtst bij de oorspronkelijke betekenis van het woord. Het heeft dan niet zozeer betrekking op een 'aanbod' van de kant van de arts, maar op de beleving en de situatie van de patiënt - de patiënt die zichzelf, zijn persoon en zijn leven als 'integer' ervalart en opvat (vgl. De Geus 1974, 2538). Deze meer oorspronkelijke betekenis komt ook in ons woord "Integriteit" (= ongeschondenheid) tot uiting. Buma, die het genoemde onderscheid ook makt, spreekt hier van de tweede betekenis van het woord integer. Hij geeft aan dat de hulp van de huisarts die gericht is op de mens als totaliteit ook het herstel van de integriteit van deze totalitelt" dient te beogen (Buma 1950,$139 ; 1 d .180)$.

vanuit deze meer oorspronkelijke, met het woord integriteit verbonden, betekenis wil ik nu verwijzen nar de joodse traditie.

5.2.2. Joodse stemmen over integriteit.

Ofschoon in de joodse literatuur de woorden "integer" en "integriteit" weinig voorkomen, is in het jodendom de menselijke integriteit wel voortdurend an de orde. In de Talmoed staat: 'When man is led in for judgment he is aked, Did you deal faithfully - i.e. with integrity" - en dan volgen nog een aantal zaken die op het gaaf mens zijn betrekking hebben (Bab.Talm. Shabbath,31a). Voor Hesche1 is de integriteit van de mens geen vanzelfsprekende zaak, mar een opdracht ("mitswa" in het Hebreeuws) die telkens weer vervuld moet worden. "Jewish tradition, though conscious of the perils and pitfalis of existence, is a constant reminder of the grand and everlasting opportunities to do the good" (Heschel 1955, $\left.1976^{3}, 377\right)$. De Talmoed zegt hierover: "We who 
walked in integrity, of us it is written, "The integrity of the upright shall guide them" (Prov.XI, 3). But of others, who walked in perversity, it is written, "but the perverseness of the treacherous shall distroy them' (ibid.)" (Bab.Talm., Shabbath 88a-b).

Het is voor de mens een opgave integer te zijn. "It is easier to discipline the body than to control the soul. The pious man knows that his inner life is full of pitfalls. The ego, 'the evil arive", is constantly trying to enchant him. The temptations are fierce, yet his resistance is unyielding. And so he proves his spiritual strength and stands victorious, unconquerable. Does not his situation look glorious? But the 'evil drive' employs a more subtle device, approaching him with congratulations: what a pious man you are! - He begins to feel proud of himself. And there he is caught in the trap" (Heschel 1955,1976 3 ,388).

Integriteit heeft niet alleen op het menselijk handelen betrekking, maar ook op het denken, merkt Heschel voorts op. "Psychological (and sociological) research has disclosed not only how the motivations of our conduct are entangled in the functions of instinctual desires, but also how the vested interests of the ego penetrate not only moral motivation but also acts of cognition" (id.,389).

Heschel wijst erop, dat de mens vrij van zichzelf en van zijn egolstische behoeften moet zien te worden (id..397-399). Het zou goed zijn als hij zich bewust ist van zijn innerlijke slavernij aan zijn 'ego'. Van de mens wordt niet gevraagd dat hij een volmakte zienswijze bereikt. Wel, dat hij van moment tot moment zijn eigen ik overstijgt. Hij moet, aldus Heschel, vermijden om al te lang bij zichzelf stil te staan, hij behoort zich op zijn taak konsentreren. Als hij juist en goed handelt wordt het goede versterkt, ook al is dit handelen niet volmakt. "Whatever we do is only a partial fulfillment; the rest is completed by God" (id.,406;vlg.Buber 1953,290- 
293).

Integriteit heeft te maken met hoe met het kwade wordt omgegaan. Het onderscheid tussen goed en kwaad noemt Heschel van groot belang. "To teach humanity the primacy of that distinction is the essence of the Biblical message" (id.,372). Goed en kwaad zijn geen waarden zoals andere warden. zij gaan veel verder en zij hebben met de keuze en met hiet onderscheid tussen leven en dood te maken. "Good is life and evil is death" (id.,373). Integriteit wil zeggen dat bewust voor het leven wordt gekozen en dat alles wat iemand voor heeft en wat hij doet in dit perspektief wordt geplaatst. Het leven is er om te worden 'gerealiseerd" of, zoals dit in de joodse traditie uitgedrukt wordt, om te worden 'geheiIigdi (zie Buber 1933,25; Rosenzweig 1921, $\left.1976^{4}, 426-427\right)$.

Deze heiliging van het leven wordt in de konfrontatie en in de relatie met de ander opgeroepen. "The problem of living does not begin with the question of how to take care of the rascals, of how to prevent delinquency or hideous crimes. The problem of living begins with the realization that all of us blunder in our dealings with our fellow men" (Heschel $\left.1955,1976^{3}, 383\right)$. In de konfrontatie met de ander kan de mens niet neutraal blijven. "Neutrality is an illusion", zegt Heschel (id., $382)$ en het is onze primaire taak "how to deal with the neutral" (id.,383). Heschel raakt hier de kern van ons gezond, dat wil zeggen op leven gericht, bestaan. "To be is to stand for, and what man stands for is the great mystery of being $H i s$ partner. God is in need of $\operatorname{man}^{\text {in }}$ (id.,413; zie id.,1951,1977², 241-251; verder hoofdstuk 6).

Zo handelen dat we daadwerkelijk voor het leven van de ander instaan, is niet alleen van betekenis omdat het iets zegt over de integriteit van de handelende persoon (vgl.Heschel). maar ook omdat men daarmee instaat voor de in- 
tegriteit van de ander. Ook in de geneeskunde, als vorm van helpende omgang met de ander, gaat het erom, dat de ander weer ruimte krijgt om te leven. Op sublieme wijze heeft David Hartman enkele jaren geleden uitgewerkt wat het wil zeggen om ruimte te scheppen voor de integriteit van de ander (Hartman 1982,5-10; zie ook op 't Root $1982,59-62$ ).

Aansluitend bij Maimonides vat Hartman de geschiedenis op als een beweging die van openbaring naar verlossing leidt (vgl.ook hoofdstuk 2). Hij karakteriseert dit gebeuren "as the movement from the tyranny of subjectivity from the framework in which man sees the world and God out of his own hungers and fears - towards the stage in which reality can be perceived and understood in terms of its own intrinsic worth" (Hartman 1982,5).

Dit weten berust niet zozeer op een louter kognitief kenproces, maar eerder op "the ability to hear and respond to that which is other than myself in terms of its own intrinsic worth". (id.,5). Hartman ziet deze beweging als een beweging die overgaat van een "narcistische egostruktuur" naar "objektiviteit", dat wil zeggen als de beweging van een leven dat op angst ("jir'aah" in het Hebreeuws) gebaseerd is en hierdoor het leven (subjektief) vorm geeft naar een leven van volledige objektiviteit, dat in liefde ("achavaah") gericht is op het primat van de ander en diens integriteit. Hartman benadrukt dat dit proces van verlossing niet theocentrisch mar antropocentrisch van opzet is: "it always must be seen in changes in the human condition" (id.,5). De mens moet hierbij de beslissingen nemen. Hij moet veranderen.

In de verlossende beweging die gericht is op de ontwikkeling van de integriteit van de ander onderscheidt Hartman drie stadia. Het eerste stadium betreft de situatie van het kind. Als kind is de mens totaal afhankelijk, ook al is hij iemand anders (iemand met een eigen in- 
tegriteit) dan zijn ouders. De centrale vraag, die zowel opgat voor de gezinsstruktuur als in matschappelijk-ekonomische situaties, is dan deze: "Can those who sustain a person, enable the person to become other? or does the sustaining become a key for manipulation? Is hunger used as a way to create control? (...). or can hunger be used in a very gentle way in order to create a distancing, using Buber's term? Can there be the experience of distancing, although man is an utterly dependent being? Are dependency and intrinsic dignity mutually contradictory experiences?" (Hartman $1982,8)$.

In het tweede stadium makt de ouder plaats voor de school. In de school heeft de leerling de ander nodig om te leren, om kontakt te maken met de kultuur en de geschiedenis. Behalve op het gebied van de (eerste) levensbehoeften, met andere woorden op ekonomisch gebied, behoort de mens ook kognitief de mogelijkheid van ruimte voor de eigen integriteit te krijgen. Hartman merkt hierbij nog op dat de vrees van de moderne mens voor het hebben van kinderen uitgaat van de illusie, dat men als individu op zichzelf "heel' kan zijn. Wat men als vrees voor het kind aanduidt, houdt echter eerder in dat men bang is dat de eigen kwetsbaarheid aan het licht komt. Iedereen die kinderen heeft weet immers dat hij niet volmakt is. Kinderen zijn voor (de toekonst van) het leven van wezenlijk belang. "If there is anything which is redemptive, it is living with children. When modern man seeks the illusion of perfection, he seeks building families without children. In a sense, therefore, the fear of dependence, the fear of having to recelve from others, makes it possible to create room for a genuine sense of otherness" (id.,9). Ik verwijs hier ook naar de op het eind van hoofdstuk 3 geciteerde 'midrasj', war gezegd wordt, dat, als er geen kinderen zijn, er ook geen Torah-leerlingen zijn en daarmee ook geen leerhuizen. En dit 
betekent dat de integriteit van God en van de medemens niet wezenlijk erkend wordt (zie Midrash Rabbah, Lev.R.XI.,7).

Het derde stadium betreft de volwassen mens. "The third stage in the creation of the dignity of the other is the movement from the cognitive to the erotic, the sensual, the sexual, the passionate love between man and woman. Here, the fulness of otherness begins to emerge" (Hartman 1982,9 ). Seksualiteit kan een instrument voor manipulatie zijn, maar het houdt ook de mogelijkheid in de ander te bevestigen in diens volle persoonlijke wardigheid en integriteit. Hartman geeft aan hoe in de intimiteit van de liefdesrelatie ruimte voor integriteit aanwezig is. "There can be distance and yet intimacy. The highest challenge is to enter into an authentic relationship in which people live totally naked with each other, and yet feel a distance which guards their personal integrity. This final stage is really the redemptive mode1" (id.,9).

Als Hartman deze drie stadia uitgewerkt heeft gaat hij nog een stap verder. Hermann Cohen (leraar van o.a. Franz Rosenzweig) heeft erop gewezen dat de bijbel de volgende twee geboden kent: 'heb je naaste lief' ep 'heb de vreemdeling lief' (Cohen 1919,1978, $137-140$ ). Hierbij aansluitend stelt Hartman dat de liefde twee stadia kent. Het eerste stadium is de liefde tot de naste. Kenmerkend is dat je vast gelooft dat je degene van wie je houdt werkelijk kent. Maar er is van een tweede, nog diepere, dimensie sprake. Ook hier gaat Hartman uit van de liefde tot iemand die je nabij is: "the deeper dimension of love, the greatest gift that occurs in love, is that after having loved a woman for years in intimacy, one says one day: You know, I really don't know you. You're a mystery. I thought I knew you. Suddenly you are shocked into awakening: that what you thought you had and possessed, turns into an independent mystery, Your neighbour turns into the stranger" (Hartman 1982, 
10).

De vraag is of we déze ruimte voor de integriteit van de ander - de ander die een ander is en dit wil zijn en met wie we toch verbonden zijn - kunnen scheppen. Zo'n ander is namelijk de vreemdeling. Hartman neemt zijn plaats in en zegt: "The question is, when $I$ walk as the stranger, will you be able to still say: 'Him I love?" (id.,10).

Bij Hartman heeft het woord integer weinig te maken met een eenheid of heelheid van de mens op basis van samengevoegde of samen te voegen aspekten. Integer heeft betrekking op een oorspronkelijk gegeven, dat voorafgaat aan en uitgaat boven mijn mogelijkheden over de andere mens integraal te denken. Doordat de mens integraal, dat wil zeggen integer, mens is, wijkt hij als het ware steeds terug als ik hem wil vangen, al mijn goede, dat wil zeggen van mijn kant integere, bedoelingen ten spijt. Op antropologisch nivo laat de ander zich niet volledig kennen. De ander blijft zichzelf. Hij is niet tot mijn leven terug te brengen. zijn levensloop is niet mijn levensloop. Hij is als mens "bijzonder', zo drukt Rosenzweig dit uit (zie hoofdstuk 2).

Dit wil niet zeggen, dat zijn bijzonderheid of integriteit voor mij en mijn bijzonderheid voor hem geisoleerde posities zijn. Beslist nilet, en zo hebben Hartman en ook Rosenzweig dit niet bedoeld. De bijzonderheid en integriteit van de ander kan men eerst leren kennen in de relatie met de ander. Eerst als men bereid is de ander in zijn bijzonderheid tegemoet te treden opent de ander zich in zijn integriteit. Hiervoor is het nodig dat men van diens plaats uitgaat.

ook de arts heeft met deze bijzonderheid c.q. integriteit van de andere mens te maken. Deze eigenheid van de patiênt mag niet als 'weerstand' opgevat worden, weerstand die dan doorbroken moet worden. De ander is geen "prooi" voor de arts of iemand die zich tegen de arts 
teweer stelt. Integendeel, "hij kan zich ook en dán toont hij mij zijn gezicht - boven iedere mat uit, tegenover mij stellen - door de totale onbedektheid en de totale naktheid van zijn weerloze ogen, door de (op-) rechtheid en de absolufe openheid van zijn blik" (Levinas $1969,1971,145)$. Op zo' $n$ moment komt een relatie tot stand, een relatie tot het absoluut Andere, en wordt aan mijn imperialisme een halt toegeroepen (id.,145). Eerst dan krijgen patiënten de kans "het lied te zeggen dat zij hadden willen zingen" (De Geus 1970,49). De arts die de ander werkelijk integraal benadert doet dit niet alleen vanuit een vooraf gedacht konsept over de 'hele' mens, maar eerder omgekeerd: de akseptatie en bevestiging van de integriteit van de ander leidt ertoe, dat de huisarts integrale geneeskunde bedrijft. Het integrale konsept vraagt als het ware om een beweging vooraf, om een handeling warbij (de integriteit van) de ander vooropstaat. Het is deze persoonlijke geneeskunde die de basis vormt van een geneeskunde die integraal, dat wil zeggen integer, is. Het joodse weten omtrent integriteit kan hierbij verrijkend $z i j n$ en tevens een toetssteen voor een werkelijk integrale geneeskunde.

5.3. Levensloopgeneeskunde en de levensen tijdsbeleving vanuit de joodse traditie.

$5 \cdot 3 \cdot 1$ Levens loopgeneeskunde.

Een tweede kenmerk dat in de huisartsgeneeskundige literatuur wordt genoemd, is de levensloopgeneeskunde. Alhoewel de achterliggende gedachten al van veel oudere datum zijn, wordt eerst de laatste jaren de levensioopgeneeskunde als een belangrijk konsept van de 
huisartsgeneeskunde nader uitgewerkt. Met name Van Es houdt zich hiermee bezig. Hij wijst erop dat voor de huisarts inzicht in de levensloop van zijn patiënten met het oog op ziekte en gezondheid een relevante zaak is. Dat de levensloopgeneeskunde door de huisarts erkend wordt is voor hem "een impliciet pleidool voor een vele jaren durende relatie tussen een huisarts en een patiënt" (Van Es $1980,228)$.

Huygen, die de term levensloopgeneeskunde in 1978 in het zogenaamde paradigmanummer van "Huisarts en Wetenschap" naar voren bracht, ziet de levensloopgeneeskunde als een aparte dimensie die aan de integrale geneeskunde toegevoegd behoort te worden. "De participerende observaties van de huisarts" zo zegt hij, "stellen hem in principe in staat tot de ontwikkeling van een levensloopgeneeskunde, waraan naar mijn mening juist grote behoefte is door steeds verdergaande fragmentatie van de klinische geneeskunde" (Huygen 1978b,449). Van Es noemt niet alleen de levensgeschiedenis van iedere patiënt met diens specifieke persoonlijkheidsstruktuur als een relevante faktor waarmee de huisarts rekening moet houden, maar hij zegt ook dat de huisarts er attent op moet $z i j n$, dat gebeurtenissen in het leven als stoornissen op het gebied van de gezondheld beschouwd kunnen worden (Van Es 1980,24-25). Door deze aandacht kan het werk van de huisarts "een min of meer specifieke verdieping" ondergaan (Van Es 1983, II/3-1).

In het rapport 'Kenmerken van de huisarts II' stat de levensloopgeneeskunde als een hoofdof basiskenmerk van de huisartsgeneeskunde genoemd. "Eén van de basiskenmerken van de huisartsgeneeskunde is dat de huisarts een kontinue of episodische relatie met zijn patienten onderhoudt. Hij is daardoor in de gelegenheid voort te bouwen op voorafgaande ervaringen met een patiënt en op de kennis en het inzicht, die hij daarbij heeft opgedaan. ook als de huisarts een patiënt nog niet zo 
lang kent is hij hiertoe al in staat door gebruikmaking van dossiers van vorige huisartsen. Het meest belangrijke is echter de gerichtheid van de huisarts; hij zal de levensloop van de patiënt altijd tot zijn aandachtsveld rekenen en hiervan gebruik maken bij preventie, diagnostiek en therapie. Dit kan ook al gebeuren als hij de patiënt nog maar kort kent. Bij de eerste kontakten met de patiënt dient hij aan deze aspekten in het bijzonder andacht te besteden" (Van Es e.a. $1983,26)$.

De faktoren die in de levensloopgeneeskunde relevant zijn en waaraan de huisarts bewust en aktief aandacht behoort te besteden betreffen zowel "faktoren uit het gezin van herkomst" als faktoren die te maken hebben met "de gang door de eigen geschiedenis" (Van Es 1983,II) 3-3 en 3-5). Voor de huisarts relevante aspekten zijn dan:

"- voorafgaande ziekten,

- preëxistente afwijkingen,

- het periodiek optreden van klachten,

- reaktie op ziek zijn.

- reaktie op behandelen.

- problematiek gekoppeld aan levensfasen".

(Van Es e.a. 1983,26-27).

De levensloopgeneeskunde is volgens Van Es en het genoemde rapport niet alleen van belang voor preventie, diagnostiek en therapie, maar ook omat zij uitgaat van het respekt voor de persoonlijkheid van de patiënt en dit stimuleert (id., 27,Van Es 1980,228). "Dit respect is een basisvoorwaarde om de patiểnt op de juiste wijze terzijde te kunnen staan, te adviseren, te behandelen en nar hem te luisteren. Zonder dit respekt is een echte communicatie niet mogelijk" (Van Es 1980,228). De grondslag van de levensloopgeneeskunde, zo stelt Van Es, "is de fundamentele belangstelling die men voor de medemens koestert" (Van Es 1983,65$)$. Ik wijs er overigens op dat de joodse traditie niet zozeer wil spreken van 
belangstelling voor de medemens, mar zegt dat het fundament warom de een zich met de ander inlaat, de verantwoordelijkheid voor die ander is (zie o.a. Strasser 1981,105-108).

Het konsept van de levensloopgeneeskunde is in de huisartsgeneeskunde wel benoemd, maar men kan nog niet zeggen dat het om een reeds uitgekristalliseerde opvatting en benaderingswijze gat. Eén facet ervan is van wat oudere datum: het natrekken van de levensgeschiedenis van de patiënt - ook wel de biografische methode of psychosociale anamnese genoemd (Brouwer 1962) - dit met het oog op een nadere verklaring van de gezondheidstoestand van een patient op dit moment.

Er is één aspekt dat betrekking heeft op de levensloopgeneeskunde, maar dat in de literatuur veelal apart aandacht krijgt. Ik doel hier op de 'levensgebeurtenissen'. Binnen de levensgeschiedenis van patiënten gat het hier om voor het leven van de patiënt relevante gebeurtenissen. Van Eijk omschrijft een levensgebeurtenis als: "elke gebeurtenis, die leidt tot een voor de betrokkenen betekenisvolle verandering van een bepalde situatie, zodanig, dat gedurende een langere periode de aanpassing aan een nieuwe situatie noodzake1ijk is" (Van Eijk 1979,81).

Levensgebeurtenissen kunnen een belangrijke rol spelen bij het ontstaan van ziekte. Zo is bijvoorbeeld bekend, dat tijdens perioden van rouw meer ziektes voorkomen en dat het overlijdensrisiko dan groter is. Inzicht in de betekenis ervan is mede hierom van groot belang voor de huisarts. Dit belang is des te groter omdat bij de levensgebeurtenissen ook de omgeving en met name het gezin van de betrokken patiênten in het geding zijn (id.,170172).

Levensgebeurtenissen betreffen zeer individuele ervaringen en de betekenis ervan kan per persoon zeer verschillend zijn. Men kan hierbij denken aan gebeurtenissen die algemeen als 
ingrijpend ervaren worden zoals het overlijden van iemand die men lief heeft of de ervaringen in een konsentratiekamp (zie Frank1 1978). Maar ook andere, op het eerste oog of voor buitenstaanders soms onbetekenend lijkende gebeurtenissen of ervaringen kunnen antropologisch-gezondheidkundig van zeer grote betekenis zijn of worden. Zo hebben de gesprekken die Franz Rosenzweig met Eugen Rosenstock en enkele andere vrienden voerde, diens leven ingrijpend veranderd en van hem een 'gezond' mens gemaakt (zie hoofdstuk 2).

Nader onderzoek is geindiceerd in hoeverre juist dergelijke heel persoonlijke, soms verborgen en soms onbelangrijk lijkende momenten, gezondheidkundig van groot belang kunnen zijn. Wellicht ook geeft zo'n persoonlijk-kwalitatief onderzoek meer zicht op leven en op gezond mens zijn dan veel kwalitatief onderzoek van dit moment.

Naast het reeds genoemde aspekt van de levensgebeurtenissen is 'de tijd' en, samenhangend hiermee, het einde van de tijd van de mens, de dood, een belangrijke komponent van de levensloopgeneeskunde. Dat de levensloop met de dood eindigt, wil nog niet zeggen dat de dood bepalend is voor het leven. Ik kan aan deze zaak, hoewel van grote importantie, hier geen uitvoerige beşchouwing wijden (zie o.a. Heidegger $\left.1927,1976^{13}, 235-267\right)$. De levensloop wordt niet alleen, en Rosenzweig en de joodse traditie volgend juist niet, door de dood bepald, maar door het leven (Enc.Talm.,Vol.1, 206), het leven dat "leeft" van gebeurtenissen. Ik verwijs hiervoor naar de voorafgaande hoofdstukken.

Dit wil niet zeggen, dat dit leven niet an tijd en tijdelijkheid gebonden is. De mens is, in tegenstelling tot de dieren, zich van de tijd bewust, zegt Whitrow (Whitrow 1974,34). Tijd is voor de mens een belangrijke ervaring. De vraag nat "wat 'tijd" nu precies is, daarover hebben $z i c h$ vele filosofen het hoofd gebroken", merkt Van Benthem van den Bergh op 
in de inleiding van een themanummer over de tijd in het tijaschrift "De Gids" (Van Benthem van den Bergh 1974,597). Hij haalt dan Augustinus aan, die ooit heeft gezegd: "als me mar niet gevraagd wordt wat tijd is weet ik het wel, mar als ik het moet gaan ultleggen weet ik het niet meer" (id.,597).

De mens beleeft de tijd. Dit betekent een leven in het heden. Het betekent ook dat we vroegere ervaringen en gebeurtenissen integreren in het leven nu. We zoeken in ons leven tevens houvast in de tijd. De ordening van het leven ordent ook de tijd. Naast de levensgebeurtenissen en de dimensie van de tijd is de ordening van het leven een derde komponent die voor de levensloop van betekenis is. Het beleven van de tijd houdt voots in dat de mens hoop koestert - soms vrees heeft - en verwachtingen heeft. De levensloop is op de toekomst gericht, en toekomst is leven.

Hoe in de joodse traditie over 'leven' gedacht wordt is in het voorafgaande, en met name in hoofdstuk 3, al aan de orde geweest. Over de levensloop en met name over de ervaring van de tijd en over de ordening van het leven heb ik nog weinig gezegd. Tijd en tijdsbeleving zijn echter belangrijke dimensies in het menselijk bestaan. "Time is the heart of existence" (Heschel $\left.1951,1977^{3}, 3\right)$.

$\frac{5.3 .2 .}{\text { Levens- en tijdsbeleving in de }}$

Levensgebeurtenissen, geschiedenis, tijd en de hiermee samenhangende ordening van het leven zijn ook belangrijke konsepten in de joodse traditie. "Judaism is a religion of history, a religion of time", zegt Heschel. "The God of Israel was not found primarily in the facts of nature. He spoke through events in history. While the deities of other people were associated with places or things, the God of the 
prophets was the God of events: the Redeemer from slavery, the Revealer of the Torah, manifesting Himself in events of history rather than in things or places" (Heschel $\left.1955,1976^{3}, 200\right)$. Op zijn eigen, soms konfronterende, manier van schrijven plaatst Heschel Israëls verworvenheid, namelijk "to have experienced history, the world of time". tegenover wat de trots van de Griekse kultuur is, namelijk het idee van de ruimtelijk gedachte kosmos. En hij vervolgt: "Judaism claims that time is exceedingly relevant. Elusive as it may be, it is pregnant with the seeds of eternity. Significant to God and decisive for the destiny of man (onderstreping van mij - J.R.) are the things that happen in time, in history. Biblical history is the triumph of time over space" (id.,206).

In een andere publikatie drukt Heschel zich als volgt uit: "The Bible is more concerned with time than with space. It sees the world in the dimension of time. It pays more attention to generations, to events, than to countries, to things; it is more concerned with history than with geography. To understand the teaching of the Bible, one must accept its premise that time has a meaning for life which is at least equal to that of space; that time has a significance and sovereignty of its own" (id. $1951,1977^{3}, 6-7$ ).

Heschel wijst op een belangrijke ervaring van mensen, als hij vertolkt hoe wezenlijk de tijaservaring voor de mens en de menselijke existentie is. Het betreft hier de ervaring dat het 'momenten' $z i j n$ die indruk op mensen maken. "What is retained in the soul is the moment of insight rather than the plaçe where the act came to pass" (1d.,1951,1977 ,6). We moeten niet vergeten, zegt hij, "that it is not a thing that lends significance to a moment: it is the moment that lends significance to things" (id.,6;vgl.Rosenzweig, hoofdstuk 2 ). 
Het menselijk bestaan is zo niet alleen met ruinte, maar als 'leven' veel meer met tijd verbonden. "It is obvious that the relation of existence to time is more intimate and unique than its relation to space. There is nothing in space which is so necessary to existence. or belongs so intimately to it, that we could not abandon it without incurring any radical harm. Existence implies no possession of property, no mastery over other beings. Even the particular position we occupy in space we can freely exchange for another one, while the years of our lives are of absolute importance to us. Time is the only property the self really owns. Temporality therefore, is an essegtial feature of existence" (Heschel 1951. $\left.1977^{2}, 100\right)$.

De oude Grieken en ook wij westerlingen denken veelmeer in ruimtelijke kategorieën. "Reality to us is thinghood, consisting of sybstances that occupy space" (Heschel 1951,1977, 5 ). Wij ordenen, meten, tellen. Zo doen we ook met onze levensloop, met de tijd en met de levensordening. Wij gaan ermee om en beschouwen hen als ruimtelijk voorgestelde, gesloten, systemen. "We know what to do with space but do not know what to do about time, except to make it subservient to space" (id., 5). We meten de $t i j d$ en op basis van de als ruimtelijk-1ineair voorgestelde tijd(seenheden) $z i j n$ we in stat tot plannen. Kortom: "Unsere Handlungen werden objektiv, unpersönlich, räumlich orientiert, die Hebrâer denken subjektiv, persönlich, zeitlich" (Boman 1952,1977 ,125).

Een traditie die met de tijd omgaat alsof het lets dingmatigs is, zou wel eens een minachting voor de tijd en voor het menselijk jeven kunnen hebben (vgl. Heschel 1951,1977\%,5). "Contempt for time seems to be characteristic of human thought almost everywhere. To the Hindu as well as to the Greek mind, time, compared with eternity, appears empty, irrelevant and essentially unreal. Things that happen in history are of little significance; 
only the fimeless is truly relevant" (Heschel $\left.1955,1976^{3}, 205\right)$. Daardoor zijn we blind voorzover het Griekse denken bepalend is voor ons westerse denken - "to all reality that

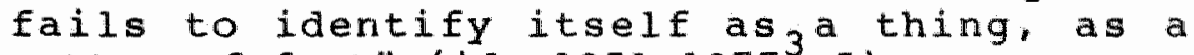
matter of fact" (id.,1951,1977 3 ,5).

We kunnen de tijd nu eenmal niet beheersen. "Wij menen de tijd te hebben mar hij heeft ons", merkt Beerling op. "Wij denken hem te kunnen gebruiken, maar hij verbruikt ons. Wij kunnen hem meten, maar alleen binnen de ons toegemeten tijd. De tijd die achter ons ligt, kunnen wij niet meer terughalen en die nog voor ons ligt is van ongewisse duur. Aan de tijd die wij beheersen zijn wij tegelijk onderworpen" (Beerling 1974,643). En Heschel zegt: "Time, however, is the most flimsy of things: a mere succession of perishing instants. It is something we never hold: the past is gone forever, what is yet to come beyond our reach, and the present departs before we can perceive it. How paradoxical and true - the only property $y_{2}$ we own we never possess" (Hesche1 1951,19772,200).

Hiervoor zei ik al dat de tijd in de Griekse oudheid en in ons westerse denken ruimtelijk opgevat wordt. Dit nu vraagt om enige differentiatie. In tegenstelling tot hetgeen in het westerse denken gemeengoed geworden is, had de tijd en ook het leven bij de Grieken een meex cyclisch karakter. Tijd en leven hebben met verandering te maken. De Grieken beschouwden alle veranderingen als uiteindelijk in eindeloze herhaling ondergeschikt an het onveranderlijke zijnde. De levensloop was voor hen een natuurlijk proces. Aan de natuurverschijnselen en daarmee ook aan de tijd kende men een cyclisch karakter toe (Kaar1s 1977,17; Whitrow 1974,11 en 14).

Het ruimtelijk-cyclisch denken veranderde met de doorwerking van het jodendom. Onder invloed hiervan èn van de christelijke geschiedenisopvatting zijn wij de tijd als een lineair 
proces gaan beschouwen (Van Arkel 1974,610: Whitrow $1974,12-15)$. Het christelijk geschiedenisachema begint met de schepping. De gebeurtenissen die in het oude Testament beschreven worden, lopen vervolgens uit op de gestalte van Christus die door zijn kruisdood en opstanding voor verzoening en verlossing zorg draagt. De fase warin wij sindsdien zitten is gericht op de voleinding (Loen 1973,123 en 131). Zo is het karakter van de christelijke geschiedenisopvatting

strikt ruimtelijk-lineair. Levensloop en menselijke tijdservaring worden geacht van deze geschiedenis deel uit te maken en eraan ondergeschikt te $z i j n$.

withrow makt een subtiel onderscheid als hij exop wijst, dat de geschiedenis volgens het Hebreeuwse denken niet ruimtelijk-lineair, maar historisch-voortschrijdend opgevat wordt (withrow 1974,14 ). In de joodse traditie heeft geschiedenis niet de betekenis van het geheel van het leven c.q. van de tijd of, zoals Loen zegt, van "gebeuren als geheel van zijn tijde1ijke uitgestrektheid" (Loen 1973,191), maar van geschiedenis 'als tijd', van gebeurtenissen die telkens heden platsvinden. Geschiedenis is "het gebeuren dat zich heden aan het voltrekken is" (id.,101). Dit gebeuren kent goede en slechte momenten, mar het blijft om één gebeuren gaan. Ook in tijden van verval is er nog altijd joods leven. Het kent geen caesuur die of een punt dat bepalend voor de geschiedenis zou zijn. Het is deze subjektiefpersoonlijke geschiedenisopvatting die kenmerkend is voor de joodse traditle. De christe1ijk-westerse opvatting is hiertegenover meer objektief-procesmatig. Bovendien kent zij twee fasen vóór en ná Christus.

In de joodse traditie is de levens- en tijdsbeleving van verleden-heden-toekomst van een geheel eigen karakter. Boman neemt in zijn studie 'Das hebräische Denken im Vergleich mit dem griechischen" met instemming kennis van de opvatting van Van orelli die in 1871 noteerde: 
"Er hätte dann gefunden, dass in den indogermanischen sprachen die zukunft ganz uberwiegend als vor uns liegend betrachtet wird, während auf Hebräisch die zukünftigen Begebenheiten immer als nach uns kommend ausgedruckt werden, und dass diese Vorstellung im notwendigen zusammenhang mit der hebräischen zeitauffassung als ganzer steht" (Boman 1952, $\left.1977^{6}, 111\right)$.

Er is van een ruimtelijke voorstelling sprake als we zeggen dat het verleden achter ons ligt en de toekomst voor ons. De joodse traditie spreekt eerder van gebeurtenissen die ons voorgegaan $z i j n$ c.q. van gebeurtenissen die na ons komen en ons toegemoet komen. De nadruk ligt hier op de historie als voortschrijdende gebeurtenis(sen) en niet zozeer op de geschiedenis met een lineair procesmatig karakter. In schema:

\begin{tabular}{|l|l|l|l|}
\hline & verleden & heden & toekomst \\
\hline Grieks-westers & $\frac{\text { ligt ach- }}{\text { ter ons }}$ & is nu & $\frac{\text { ligt }}{\text { voor ons }}$ \\
\hline Hebreeuws & $\frac{\text { ging ons }}{\text { voor }}$ & $\frac{\text { gebeurt }}{\text { nu }}$ & $\frac{\text { komt naar }}{\text { ons toe }}$ \\
\hline
\end{tabular}

De woorden 'liggen' en 'zijn" die met betrekking tot het Grieks-westerse denken gebruikt worden, hebben een ruimtelijk-statisch karakter. Hiertegenover arukken de woorden 'voorgaan", 'gebeuren' en 'komen' een heel andere ervaring uit, namelijk een ervaring van tijd en beweging (zie Boman $1952,1977^{6}, 125$ en 211 ).

In de joodse traditie hebben de tijden en levensituaties die ons voorafgegaan zijn betekenis in het heden. De toekomst is ook niet een situatie, die we in de verte voor ons 
zien liggen, maar het 1 s leven dat na ons komt. De gebeurtenissen komen eraan: zij zijn op komst. zij liggen niet voor ons, mar zij komen nat ons toe. Letter 1 ijk toe-komst dus. Verleden, heden en toekomst zijn in de joodse ervaring van het leven in veel sterkere mate met elkaar verbonden dan bij ons het geval is. Het verleden 1 s vor ons primair geschiedenis die achter ons 1igt, die voorbij is. Zij heeft har warde toen en daar gehad, maar haar aktualiteit geldt niet direkt voor ons. Deze opvatting gaat op voor de Griekse en Romeinse kulturen, voor de christelijke midaeleeuwen en staks voor de nieuwe en nieuwste tijd. De joodse traditie en het joodse kultuurgoed darentegen wordt door de eeuwen heen als éen traditie ervaren en opgevat.

Voor de individuele mens heeft zijn levensloop met geschiedenis en met tija te maken. Vroegere ervaringen $z i j n$ belangrijk voor het leven nu en ervaringen die nu opgedaan worden, werken later door. Er is een 'zusammenhang zwischen Tat und Geschick" (Rosenzweig 1978, $2,1 d ., 21)$. De keuze waarvoor de mens komt te stan, is orm datgene wat hem in zijn leven overkomt, in zijn bestaan te integreren. Dit houdt dus in, dat men als mens de vrijheid en de mogelijkheid heeft om zowel voor het verleden als voor de toekomst verantwoordelijkheid te aragen. Dit betekent niet, dat men zich op het verleden alent te fixeren. Het betekent evenmin, dat het verleden in het nu geen rol behoort te spelen en dat men zich op het nu Elxeert. Ik wijs erop dat het hier eveneens voor de hulpverlening om relevante zaken gat. Als men de verantwoordelijkheid voor het verleden in relatie tot de hulalge situatie (en omgekeerd) niet op zich durft te nemen. dan kan men een gezond bestaan in de toekomst we 1 vergeten $(v g l, 10,26)$ Franz Rosenzweig (zie hoofdstuk 2) heeft in vrijheid deze verantwordelijkhela op zich genomen en zijn "gaaf mens" zijn verbonaen met de ervaring en oparacht een "whole Jew" te zijn (zie Abram 
$1980,219)$. Met het oog op de toekomst verbond hij zijn verdere levensloop met gebeurtenissen in het verleden, die hem nu nog bleken te raken.

Natuurlijk kent de joodse traditie een zekere opeenvolging van gebeurtenissen. Kenmerkend is echter dat de gebeurtenissen van vroeger mede van toepassing zijn op situaties nu. Het leven nu is als het leven vroeger. De 'binding van Jitsjak" uit Genesis 22 wordt bijvoorbeeld vandaag de dag herhaald war de jood om zijn jood zijn, of wie dan ook om zijn zijn zoals hij is, geknecht en vernietigd wordt (zie Zuidema 1980;id.,1982). "Dass die heilsgeschichtlichen Ereignisse in alter zeit stattfanden und in einer bestimmten Reihenfolge nacheinander eintrafen, ist den Israeliten und uns gemeinsam", noteert Boman. Maar: "dass sie aber die vergangenen Ereignisse als gegenwärtig erleben konnten, ist nur hebraisch" (Boman $\left.1952,1977^{6}, 123\right)$.

Boman is er voorstander van, dat ook wij Europeanen leren om het leven, om dat wat gebeurt, "als Tatsachen zu betrachten, welche sind und bleiben" (id.,119). Ook wij zouden lets van de Hebreeuwse levenshouding kunnen ervaren "sobald wir aufhören, die Zeit als etwas Răumliches, statisch Festlegbares, fast sichtbares aufzufassen und statt dessen die Zeit als das transzendentale Schema der Geschichte (...) anerkennen. Dann missen wir uns selbst als lebende Menschen vorstellen, die auf Wanderung von der Wiege $z u$ dem Grabe sind und in lebendiger Verbindung mit der Menschheit stehen, die auch unaufhơrlich vorwäts wandert" (id., 129).

Juist dit makt de eenheid van het leven uit, zoals deze in de joodse traditie geldt. De gebeurtenissen uit het verleden die in de joodse traditie centraal staan (dat wil dus zeggen, ook nu aktueel zijn), zijn de gebeurtenissen van de uittocht uit het Egyptische slavenhuis. Ik verwees hier al eerder naar. De 
aktualiteit en relevantie van deze gebeurtenissen - de bewustwording van de slavendienst aan de Egyptische meesters, het woord bij de brandende brambos, de uittocht uit Egypte en de doortocht door de schelfzee, het verbond aan de Sinaĩ, de rondzwervingen door de woestijn, de intocht in het Land war leven is zijn tot op de dag van vandaag beleefde werkelijkheid.

Deze verlossende gebeurtenissen staan voor het leven nu, met andere woorden: "die Vergangenheit ist Gegenwart" (Friedlander 1978,32). Elke generatie heeft opnieuw weet van deze ervaring. Zij is permanente realiteit. "In jeder Generation zieht jeder Mann aus Agypten weg $^{\text {"t }}$ (id. "32;0ok Rosenzweig $1921,1976^{4}, 337$ en 354). Telkens weer wordt van de mens verlangd uit Egypte, het land van de dienstbaarheid, weg te trekken en geen slaaf meer te zijn, maar een vrije en als zodanig een 'gezond' mens. Het gaat hier om een wel heel basale ervaring van het mens zijn (Midrash Rabbah, Ex.R.XVIII, 10)

In navolging van Kierkegaard voert Boman voor deze ervaring de term 'gelijktijdigheid" in (Boman 1952,1077 ,126-128). "Der Begriff der Glelchzeitigheit, den $\mathbf{S}$. Kierkegaard und wir nur mit grösser Mihe bilden können, weil wir durch unsere Denkweise von den drei zeitspharen (van verleden, heden en toekomst J.R.) gehindert werden, ist den semiten und besonders den Hebraern in ihren Sprachen muhelos gegeben. Die Gleichzeitigkeit des Redenden mit der Handlung und dem Geschehen, von dem er redet, ist das einfachste und natúrlichste, das er sich denken kann. Wenn das Vermögen, die Gleichzeitigkeit mit der betreffenden Handlung $z u$ erleben, die wichtigste Voraussetzung fir geschichtilches verstehen ist, waren die Israeliten als ein Volk der Geschichte geboren; und wenn Gleichzeitigkeit mit den entscheidenden offenbarungsbegebenheiten die wichtigste Bedingung des Glaubens ist, hatten die Israeliten die besten natur- 
lichen Voraussetzungen, das Volk der offenbarung $\mathrm{zu}$ werden" (id.,128;vgl.id.,126).

De uittocht is zo model voor alle verlossing (Zuidema $\left.1977,1982^{4}, 115-116\right)$. Niet de slavendienst is gezond leven, maar juist de uittocht uit de slavendienst. De verlossing ging ons voor, zij gebeurt nu op dit moment én zij komt na ons. Ons leven is nu hetzelfde als het leven dat ons voorafgegaan is. Zo exvaren de Hebreeërs de tijd, zo ervaren zij hun leven. "In Wahrheit ist das Geschichtliche in ihngn ganz dichte Gegenwart" (Rosenzweig 1921,1976". 352). Het is tegelijk het leven dat naar ons toekomt. Het betekent verlangen, verwachting, uitzien nar datgene wat komt. Wij westerlingen echter zijn geneigd het leven als een ontwikkelingsproces te hanteren in plats van de levensgebeurtenissen als verlossend handelen te interpreteren. "We are today conditioned to conceive the origin of things in terms of their developments, and lack the ability to grasp suddenness, pure events, creativeness. (...). The Bible asserts that man has given himself neither his existence nor his wisdom; that both are derived from the will of God. It teaches us also that certain insights come to us not by the slow process of evolution but by His direct, sudden grant" (Heschel 1955,1976 , 207), met andere woorden door openbaring en als openbaring (zie Rosenzweig $1921,1976^{4}$;vgl. hoofdstuk 2).

In onze kultuur is het niet ongewoon in de menselijke levensloop een aantal fasen te zien. Ook de joodse traditie onderkent de levensloop als een ontwikkelingsproces met een aantal fasen. Dit proces wordt echter niet beschouwd als de gang van geboorte naar dood, een gang die op een einde gericht is en die faseerbaar en hanteerbaar is (zie Enc.Talm., Vol.1,206). Als we ten aanzien van de levensloop al van een ontwikkelingsproces willen spreken, wordt in de joodse traditie dit proces betrokken op de Torah en op de studie 
van de Torah. De levensloop is in de joodse traditie verbonden met de aard en strekking van dit leven: studie en houden van $(=$ dogn van) de Torah (Travers Herford 1945,1978'. $144)$.

In een van de belangrijkste misjna-traktaten, het traktaat "Pirké Avot", (Spreuken der Vaderen) zegt Jehoeda ben Tema: "At five years the age is reached for (the study of) the scripture, at ten for (the study of) the Mishnah, at thirteen for (the fulfillment of) the commandments, at fifteen for (the study of) the Talmud, at eighteen for marriage, at twenty for pursuit of righteousness (for seeking a livelihood), at thirty for (entering into one's) full strength, at forty for understanding (for discernment), at fifty for counsel, at sixty a man attains old age, at seventy the hoary head (for grey hairs), at eighty the gift of special strength (for 'labour and sorrow'-Ps.XC,10), at ninety he bends beneath the weight of years (for decrepitude), at a (one) hundred he is as if (thought) he were (already) dead, and has passed away and faded from the world" (Mishnah, Aboth V, 21; Hegtz 5705/1945,101-103;Travers Herford $\left.1945,1978^{9}, 144\right)$.

Direkt hierna volgt dan een uitspraak van Rabbi Yochanan ben Bag Bag: "Turn it (the Torah) and turn it over again, for everything is in it, and contemplate it (look in it), and wax (grow) grey and old over (in) it, and stir not (turn not away) from it, for thou canst have no better rule than this" (Mishnah, Aboth $\mathrm{V}, 22)$.

Travers Herford licht toe, dat de in de misjna genoemde veertien fasen weer in drie groepen ingedeeld kunnen worden. De eerste groep bevat de eerste vijf levensstadia. Deze hebben betrekking op de voorbereiding op de taken en verantwoordelijkheden die straks door de volwassene gedragen moeten worden. Deze volwassenheid vormt de tweede groep. zij omvat de periode van het twintigste tot het zeventigste 
levensjaar. De derde groep heeft op de laatste levensstadia betrekking. Uit deze gegevens blijkt, dat de mens gedurende vijftig jaar in staat kan zijn het beste van zijn leven te geven voor de praktische vervuliing van de Torah, "the doing of all the mitzvoth with the most perfect devotion of heart and will, the giving of all the personal force he can do that service of God for which Torah is the guide" (Travers Herford $1945,1978^{9}, 144-145$ ).

De levensloopgeneeskunde richt zich op de individuele persoon en diens leven. Tijd en gebeurtenissen spelen in ieder mensenleven een belangrijke rol. Het is in de huisartsgeneeskunde van belang de voor de (geestelijke) gezondheid van de patiënt belangrijke gebeurtenissen te traceren en hier een gezond, dat wil zeggen een op leven gericht, perspektief aan te geven. Het joodse weten is een model hiervoor, zoals degene die de keuze makt dit te leren kennen, zal ervaren.

De tijd en de gebeurtenissen die de tijd konstitueren zijn niet alleen bepalend voor het leven van de individuele mens, maar zijn zijn tevens een belangrijk gegeven voor het leven van de gemeenschap (en omgekeerd). De gebeurtenissen zoals de joodse traditie die als essentieel voor het leven geinterpreteerd heeft zijn ook essentieel voor de ordening van het leven. In de joodse traditie wordt de tijd en daarmee het leven van de mens en de gemeenschap wel op een bijzondere manier geordend. In een aparte paragraaf ga ik hier uitvoerig op in. Niet alleen de Torah geeft leven (zie hoofdstuk 3), maar ook de hiermee verbonden levensordening.

5.3.3. ordening van het leven.

Een traditie die ruimtelijk denkt zal de ordening van het leven ook in ruimtelijke termen 
en kategorieën ter hand nemen. In vergelijking hiermee zal een traditie die de ervaring van de tijd het meest nabij is, haar leven ordenen vanuit de gebeurtenissen die zij als de bron van haar levenstraditie beschouwt. De architectuur van de joodse traditie is geen architectuur van de ruimte en in de ruimte, maar een architectuur van de tijd. "Judaism is a religion of time aiming at the sanctification of time (Heschel $1951,1977^{3}, 8$ ).

Het is een dag die in de joodse traditie tijd en leven ordent, namelijk de sabbat. "The sabbaths are our great cathedrals" (id.,4). Het levensritme van de dagen wordt gedragen en gevoed door de zevende dag. "The meaning of the Sabbath is to celebrate time rather than space. Six days a week we live under the tyranny of things of space; on the Sabbath we try to become attuned to holiness in time. It is a day on which we are called up to share in what is eternal to time, to turn from results of creation to the mystery of creation; from the world of creation to the creation of the world (id.,10); Deze woorden zijn van Abraham Joshua Heschel in zijn prachtige boekje "The Sabbath. Its meaning for modern man'.

Wat de joodse traditie an de mensheid gegeven heeft is ruimtelijk weinig imponerend. De joodse traditie schonk ons wel iets van een bijzondere orde: een paleis in de tijd. "The seventh day is a palace in time, which we built" (1d, 14-15). De sabbat is 'het grote geschenk van Israël aan de wereld' (Ehrlich $1978,9)$. Vanuit het oogpunt van de (geestelijkel gezondheid is de sabbat van het grootste belang.

De sabbat is niet door Israël ingesteld, maar hij is a an Israël gegeven (zie Gen.2:2-3). "The Holy One, blessed be He said to Moses, I have a precious gift in My treasure house called the Sabbath, and desire to give it to Israel, zegt de Talmoed (Bab.Talm., Shabbath 10b). De traditie leert dat de Torah op de sabbat aan Israël werd geschonken. "All agree 
that the Torah was given to Israel on the Sabbath. (For) there it is written, Remember "the Sabbath day, to keep it holy" (Ex.XX,8); whilst elsewere it is written, 'And Moses said unto the people', Remember, 'this day" (Ex. $\mathrm{XIII}, 3)$ : just as there (he spoke) on that very day, so here too it was on that very day" (Bab.Talm., Shabbath 86b).

In het scheppingsverhaal kunnen we lezen hoe God zes dagen met de ruimte en met 'ruimtelijke' en fysieke zaken bezig is. Mar de zevende dag wordt apart gesteld. De zevende dag wordt de dag om te rusten en bovendien wordt deze geheiligd, hetgeen op lets bijzonders duidt. De zevende dag wordt de dag van de tijd.

"Vollendet hatte Gott am siebenten Tag seine Arbeit, die er machte,

und feierte am siebenten Tag von all seiner Arbeit, die er machte.

Gott segnete den siebenten Tag und heiligte ihn" (Im Anfang 2,2-3;Gen.2:2-3;zie Bab.Talm, Shabbath 86b).

Het is op dat moment dat het woord heilig, "kadosj", voor het eerst uitgesproken wordt. Het heeft niet op een plaats betrekking, maar op tijd (zie Zuidema 1977,1982,85-109). "One of the most distinguished words in the Bible is the word 'qadosh', holy; a word which more than any other is representative of the mystery and majesty of the divine. Now what was the first holy object in the history of the world? Was it a mountain? Was it an altar?" (Heschel 1951,1977\%,9). Noch de altaren die de oude volkeren op een door hen als heilig bevonden plaats bouwden, noch de berg olympus in het antieke Hellas was het eerste heilige objekt. Het was trouwens niet eens een ding, maar een dag die de naam 'heilig" kreeg. "It is, indeed, a unique occasion at which the distinguished word 'qadosh' is used for the first time: in the Book of Genesis at the end of the story of creation. How extremely sig- 
nificant is the fact that it is applied to time: "and God blessed the seventh day and made it holy" (Gen.2:3). There is no reference in the record of creation to any object in space that would be endowed with the quality of holiness" (1a.,9).

De zevende dag, de dag van de tijd, wordt geheiligd, dat wil zeggen apart gesteld van de andere dagen, de dagen van de ruimte. Zoals een bruid gezegend en apart gesteld wordt en verbonden met haar bruidegom, zo wordt de sabbat gezegend en apart gesteld en verbonden met Israë1. In een midrasj over de sabbat staat: "Therefore the Lord blessed the Sabbath day and sanctified it. (The literal meaning of 'sanctify' is 'to separate'. So God separated the Sabbath). It has no partner. All the other days of the week go in pairs, but the seventh day has no partner. The sabbath said to God 'The other days have partners; I have no partner'. God said: 'Israel shall be thy partner" (Pesikta Babbati 117b, in Montefiore and Loewe $\left.1974,1978^{3}, 195\right)$. Dit vraagt van Israël de sabbat in ere te houden. En ook hier gat de vergelijking met de bruidegom en de bruid op.

Behalve een 'persoonlijk' heeft de sabbat ook een 'legaal' karakter. Het legale karakter komt hierin nar voren, dat aan de sabbat vorstelijke soeverelniteit toegekend wordt. De sabbat wordt een koningin genoemd. Het persoonlijke karakter van de sabbat komt naar voren, zoals al gezegd, wanneer de sabbat als 'een bruid' betiteld wordt. Ook dit wijst op lets heel bijzonders. Heschel vat het soevereiniteits- en het persoonlijke aspekt in én zin samen als hij zegt: "The sabbath is $3^{\mathrm{a}}$ queen as well as a bride (Heschel 1951,1977 . 62). De Talmoed zegt: "R. Hanina robed himself and stood at sunset of sabbath eve (and) exclaimed, 'Come and let us go forth to welcome the queen Sabbath' Rabbi Jannai donned his robes on sabbath eve and exclaimed, 'Come, 0 briae, come o bridel" (Bab.Talm., Sabbath 
119a). En op een ander moment leert de Ta1moed: "R.Hanina used to say: "Come, let us go forth to meet the bride, the queen!' some (explicitly) read: '...to meet Sabbath, the bride, the queen". R.Jannai (however) while dressed in his Sabbath attire used to remain standing and say: "Come thou, $O$ queen, come thou, O queen!" (Bab.Talm. "Baba Kamma $32 a-$ $32 b)$.

In onze westerse samenleving gaan we ervan uit dat we een wekelijkse rustdag nodig hebben om 'bij te komen' van ons werk. We kunnen niet voortdurend blijven werken. We hebben een rustdag nodig om weer voldoende op krachten te komen voor het werk dat we moeten doen. "Dat de mens één dag zal rusten van zijn werk, lijkt ons een vanzelfsprekende, sociaal-hygiënische matregel", zegt Erich Fromm. De bedoeling hiervan zou dan zijn "om de mens de lichamelijke en geestelijke ontspanning en rust te geven, die hij nodig heeft om niet door zijn dagelijkse werk overspoeld te worden, en om hem in staat te stellen gedurende de zes werkdagen zijn werk beter te doen" (Fromm 1975,138).

De vrije dag is een sociale verworvenheid. Hiermee wordt alle nadruk gelegd op het werken, op arbeid. Toch is dit niet de bedoeling van de sabbat als rustdag, hoe belangrijk deze rustdag als "sociale institutie" ook is. "De Sabbat ist nicht nur eine soziale Institution, die auf Grund eines Abkommens zwischen Arbeitspartnern geschaffen wurde, sondern er erhält seine letzte Begrindung durch Gott. Es ist ein Ruhetag Gottes, ein daher durch Ihn gehelligter und gesegneter Tag" (Ehrlich $1978,9 ; i d ., 1978 b, 15)$. De week is niet alleen "Dienst der Erde" - "die Arbeit der 'Kultur' soll sie rhythmisch regeln" - zij is niet alleen een menselijke ordening van de kultuur, max zij is ook "iraisches Gleichnis des Ewigen; als gottgesetztes Gesetz des Kults zieht sie das Ewige nicht bloss gleichnishaft, 
sondern in Wirklichkeit hinein ins Heute" (Rosenzweig 1921, 1976,324 ).

De sabbat staat niet ten dienste van de werkdagen, mar het omgekeerde: "The weekdays are for the sake of the Sabbath" (Heschel 1951, $\left.1977^{3}, 114\right)$. Als de sabbat ten dienste van de werkdagen zou staan had de sabbat de funktie van "relaxen" om weer nieuwe kracht op te doen voor het werk. "To the biblical mind, however, labor is the means toward an end, and the Sabbath as a day of rest, as a day of abstaining from toil, is not for the purpose of recovering one's lost strength and becoming fit for the forthcoming labor. The sabbath is a day for the sake of life" (id.,14). Immers, daarom gat het in de joodse traditie: om leven. "The purpose of the Torah is "to bring life to Israel, in this world and in the world to come" (id.,17). En feitelijk is al het werk hierop betrokken, ook het doordeweekse. Uit de chassidische literatuur is het volgende verhal bekend over wat het belangrijkste doel van ons leven en werken is: "De Gerer Rabbi zei: 'De Talmoed noemt 39 verschillende soorten werk, die noodzakelijk zijn voor de bouw van de tabernakel. Al deze vormen van arbeid hadden één hoofddoel: de Tabernakel'. En de rabbi vervolgde: 'In onze verschillende bezigheden op de gewone werkdagen zouden we eveneens op één hoofddoel de nadruk moeten leggen: namelijk de plicht on de sabbat te eerbiedigen. Dan zullen al onze handelingen geheiligd worden" "(Newman 1976,51).

De sabbat is zó belangrijk voor Israël, dat niet alleen het werk op de doordeweekse dagen op de sabbat betrokken is, mar dat ook de ordening van de dagen zelf gericht is op de sabbat. "R.Jizchak lehrte: Du sollst die Wochentage nicht nach der Art der anderen Völker benennen, sondern sie im Hinblick auf den Sabbat zăhlen (als den ersten, zweiten, dritten Tag der Sabbatwoche usw...." (Zobel 1935,51).

In onze samenleving met zijn geweldige tech- 
nische verworvenheden lijkt het ex een beetje op alsof het werken voor deze verworvenheden het belangrijkste levensdoel is (zie Fromm $1982,51-52)$. Toch $\mathrm{zijn}$ werken en het resultat van ons werken niet bepalend voor ons menselijk leven. Op de sabbat leren we om verder te kijken dan onze technische beschaving. "The Sabbath is the day in which we learn the art of surpassing civilizatiqn" (Heschel 1951, $1977^{3}, 27$; vlg.id..1959,1975, 233$)$. "The aim of the sabbat is to show what should be the finality, the right orientation, the just use of man"s scientific-technical process" (Kahn $1983,5)$.

Fromm merkt op dat in de bijbel en in de latere talmoedische literatuur werken niet verbonden wordt met lichamelijke inspanning alleen. "Werk is", zo zegt hij, "ieder ingrijpen van de mens in de fysieke wereld, hetzij constructief, hetzij destructief. Rust is een toestand van vrede tussen de mens en de natuur" (Fromm 1975,139). De sabbat is dan de steeds weer komende dag van de volkomen samenhang tussen de mens en de natuur, de mens en de mens, en de mens en God. Met andere woorden: "Op de sabbat is hij (de mens) volledig mens, met geen andere taak dan ook inderdaad mens te zijn" (id.. 139;vgl. Tomson 1981,68). Op de sabbat bereikt de mens wat hij is: heel, gezond mens te zijn. Het ritme van de sabbat laat zien dat het menselijke leven op antropologisch nivo volledig verschilt van elke natuurlijke cyclus (Terracina 1984,22 ).

Dat de sabbat "surpassing of civilization" (Heschel) is, wil zeggen dat deze ene dag anticipatie is op de ene sabbat, op het 'Rijk Gods" (Rosenzweig), op "de messiaanse tijd, die dan ook soms de tijd van de eeuwigdurende sabbat genoemd wordt" (Fromm 1975,140). Fromm wijst erop dat hiermee niet louter en alleen een symbolische anticipatie van de messianse tijd bedoeld wordt - nee, "het is de reële voorbode ervan". Ik citeer verder: "Zoals de 
Talmoed zegt: "als geheel Isräl slechts eenmal twee sabbatten (achter elkaar) volledig in acht zou nemen, dan zou aaristonds de messias komen' (Talm.Bab. Shabbath 118b). De sabbat brengt een moment van eeywigheid in het leven nu (Rosenzweig $1921,1976^{4}, 324$ ). De sabbat is de reèle anticipatie van de messiaanse tijd, niet door een magisch ritueel, mar door een gedragspatroon dat de mens in een werkelijke toestand van harmonie en vrede (van gezond mens zijn - J.R.) brengt" (id.,140-141; v1g. Rosenzweig $1921,1976^{4}, 324 ;$ Kahn 1977,6). Op deze dag wordt de dood en de angst voor de dood opgeheven en regeert het leven. Op de sabbat is er geen tijd; de tijd en de druk van de tijd zijn opgeheven. Op deze dag staan naast de studie van de Torah de vreugde van eten, drinken en liefdesspel centraal (Fromm 1975,141-142). De traditie schrijft evenzeer de sexuele omgang en goed eten voor als het rusten en leren.

De levensordening met de sabbat als centrale dag én de Torah onderscheiden de joodse traditie van alle andere beschavingen. Heschel: "Things are our tools; eternity, the Sabbaths, is our mate. Israel is engaged to eternity. Even if they dedicate six days of the week to worldiy pursuits, their soul is glaimed by the seventh day" (Heschel 1951,1977 ,48). De arbeld van de werkaggen wordt geheiligd door de studie van de Torah en door de Sabbat. Het dagelijkse werk en de resultaten hiervan staan ten dienste van het leven. Zij zijn geen doel op zichzelf, maar in hun ruimtelifke vormen zijn zij aan de tijd, aan het leven van de mens dienstbaar. De sabbat met de studie van de Torah staat centraal en overstijgt alle andere verworvenheden. We zien naar de sabbat uit "as our homeland, as our source and destination" (id.,30).

Elke week staat een tekst uit de Torah centraal en daarmee (de studie van) de Torah. Zo wordt in een jar de Torah doorgenomen en 
daarmee de tijd en het leven geordend (zie Grunewald 1970). Mede hierom is de sabbat van levensbetekenis voor de mens. Voorts benadrukt Heschel in zijn boek over de sabbat weer de waarde van levensgebeurtenissen boven die van de dingen. "New in the teaching of Judaism was that the idea of holiness was gradually shifted from space to time, from the realm of nature to the realm of histgry, from things to events" (Heschel 1951,1977, 79). Voor de mens heeft dit tot konsekwentie: "to conquex space and sanctify time" (id..101). De sabbat is de borg dat dit laatste ook waargemakt kan worden. Van ieder wordt gevraagd de heiliging van de sabbat vanuit zijn eigen situatie en op zijn eigen wijze te verwerkelijken: "R.Hiyya ben Abba said: The sabbath was given for enjoyment. R.Samuel ben Nahmani said: The Sabbath was given for studying the Torah. The one saying does not contradict the other. R.Hiyya referred to scholars who spend the week studying the Torah; when the Sabbath comes, they enjoy themselves, whereas R.Samuel was thinking of labourers, who are busy with their work all the week, and on Sabbath they come and study the Torah" (Pesikta Rabbati $121 \mathrm{a}$, in Montefiore and Loewe $\left.1974,1978^{3}, 195\right)$.

De sabbat geeft de mens de gelegenheid om bij de essentie van het leven stil te staan en deze te ervaren. De Misjna leert: "This was the singing which the levites used to sing in the Temple. On the first day they sang 'The earth is the Lord's and all that therein is, the round world and they that dwell therein' (Ps.24); on the second day they sang "Great is the Lord and highly to be praised in the city of our God, even upon his holy hill" (Ps.48); on the third day they sang "God standeth in the congregation of God, he is a judge among the gods (Ps.82); on the fourth day they sang 'o Lord God to whom vengeance belongeth, thou God to whom vengeance belongeth show thyself' (Ps.94): on the fifth day they sang 'sing we 
merrily unto God our strength, make a cheerful noise unto the God of Jacob' (Ps.81); on the sixth day they sang "The Lord is king, and hath put on glorious apparel" (Ps.93). On the Sabbath they sang A Psalm: a song for the Sabbath Day (Ps.92); a Psalm, a song for the time that is to come, for the day that shall be all Sabbath and rest in the life everlasting" (Mishnah, Tamid VII,4).

De Leldse hoogleraar Dresden eindigde zijn afscheidskollege, met als titel "het Einde", als volgt: "In het joodse denken bestat een legende die zegt dat er, zoals op aarde leerscholen bestaan, ook een hemelse academie is. In de Midrasj, een uitvoerig en dikwijls "allegorisend" commentaar op boeken van het oude Testament, wordt daarvan gesproken en vooral de beschouwingen over het boek prediker gaan er uitgebreid op in. zij mogen van betrekkelijk jonge datum zijn (VIIde eeuw), er worden zeker ook veel oudere tradities in vermeld. Altijd weer komen de opmerkingen van de verschillende geleerden erop neer, dat zij als geleerden - mar eigenlijk zullen alle waarlijk gelovigen dat zijn - na hun dood in een halve kring om God zitten en onder zijn leiding voortgaan met het lezen en nader bewerken van de Tora. Er is geen einde aan en er heerst voortdurende vreugde die gelegen is in de eeuwige opgave om woorden van onuitputtelijke inhoud steeds beter te begrijpen en te bewonderen. - Ik vind het een groots visioen, soms zou ik wensen dat het werkelijkheid was..." (Dresden 1980,70-71; v1g.Ginzberg 5727-5730/ 1967-1969, Vol. IV, 218; id. ,Vol.VI, 332).

5.4 . Enkele aantekeningen.

Kennis nemen van de joodse traditie houdt in: een leren kennen van deze traditie en dit met het oog op onze elgen toekomst en die van onze samenleving. Het is dan van belang na te gaan 
wat de belangrijkste konsepten, warden en ervaringen uit deze traditie zijn en te onderzoeken welke konsepten, waarden en ervaringen van belang kunnen zijn voor onze levenssituatie en in hoeverre zij perspektief aan ons leven en aan (facetten van) onze samenleving kunnen geven.

Dit betekent niet dat we zonder meer de betreffende konsepten binnen onze situatie kunnen gebruiken en toepassen. De Torah is geen voorwerp dat we vanuit onze eigen autonomie kunnen gebruiken naargelang het ons uitkomt. Eerder is het omgekeerde het geval: de Torah is een levenswerkelijkheid waarvoor we moeten instaan. Vanuit zijn positie schreef Franz Rosenzweig eens aan zijn ouders: "Wenn der Jude (...) angegriffen wird, dann hat er die Tora nicht als Schild vor sich zu halten, sondern er gehört vor die Tora" (Rosenzweig 1935,46; id.1979, Bd.1.95). Ofschoon de Torah zich niet als een willekeurig schild of gebruiksvoorwerp laat behandelen, is het wel zo, dat de Torah een extra dimensie aan ons leven en onze levenssituatie kan geven. Dit nu is ook het geval met betrekking tot de hier naar voren gebrachte, voor de huisartsgeneeskunde relevante. konsepten integraal en integriteit, levensloop, levensgebeurtenissen, tijd, en levensordening. Zonder dat er (op theoretisch nivo) direkt van een synthese sprake is, voegen de genoemde konsepten, zoals zij in het joodse weten aanwezig zijn, een dimensie toe aan hetgeen in de huisartsgeneeskunde over de integrale en de levensloopgeneeskunde gezegd wordt.

De huisarts is een kind van zijn kultuur. Ook $h i j$ is opgevoed en opgeleid in een samenleving die 'ruimtelijk' denkt en die gebruik heeft leren maken van de medisch-technische verworvenheden van onze kultuur. Tegelijk is er voor hem de voortdurende konfrontatie met de individuele persoon en met de vraag wat diens leven betekent. Het risiko bestaat dat de per- 
soon

"leeg" achtergelaten of weggezonden wordt. Het leven van de patiênt wordt dan, in de woorden van Heschel, wel veroverd, mar niet geheiligd (vgl.Heschel 1951,1977, 101 ). Het gezochte gezonde leven wordt dan niet echt gevonden.

Binnen de geneeskunde kan de huisarts een korrektieve funktie vervullen. Hij kan proberen, tegen de stroom in soms, in de patiëntenzorg het verhullende karakter van technische interventies te reduceren. In de wetenschap kan hij proberen niet alleen oog te hebben voor ruimtelijke kategorieên, maar ook voor de existentieel-antropologische dimensie van het leven, zoals die in het voorafgaande aan de orde waren.

De huisarts heeft voorts een bewakende funktie. De geneeskunde is, zoals zij zich op natuurwetenschappelijke basis ontwikkeld heeft onpersoonlijk en autonoom van karakter. Van belang is wanneer en hoe deze geneeskunde toegepast wordt. Terwijl de specialist meer gezien wordt als een vertegenwoordiger van de autonome geneeskunde, is de huisarts veel beter in staat een trait d'union te vormen tussen de medische mogelijkheden en het elementair verlangen van de patient naar wat we 'heling, genezing en verlossing' noemen (zie hoofdstuk 6).

Het is een hachelijke onderneming, maar ook 'de trots' van de huisarts deze moeilijke korrektieve en bewakingsfunktie in de samenleving te mogen vervulien. De huisarts neemt binnen de geneeskunde de positie van "vreemdeling" in. De huisarts laat de trow aan (het leven van) de patiènt voorgaan boven de trouw aan de geneeskundige mogelijkheden. Anders gezegd: de huisarts is degene die voor de verbinding tussen beide zorg dient te dragen. Het is onder andere dit aspekt dat het werk van de huisarts moeilijk kan maken en dat niet altijd goed begrepen wordt.

Als de wetenschap en ook de huisartsgeneeskun- 
de tezeer een intellektueel-abstrakte opstelling kiezen, valt er veel te zeggen over de mens in somatisch, psychisch en sociaal opzicht, mar zij missen dan de individuele manifestaties, dat wil zeggen de hoogst persoonlijke ervaringen die op existentieel-antropologisch nivo het leven gezond of ziek maken. Het joodse konsept van integriteit laat zien, dat het leven nooit op intellektueel-abstrakte wijze benaderd kan worden. Het mens zijn kan integraal benaderd worden, mar nooit als zodanig volledig begrepen en gevat worden. Het konsept 'integraal' in de huisartsgeneeskunde geeft een duidelijke verbreding als we gezondheid en genezen op het oog hebben, mar het is een monologisch konsept, dat geen antwoord geeft aan het mens zijn van de ander. Dit gebeurt eerst in de dialogische ontmoeting met de ander, waarbij we bij voorbaat het anderszijn van (het leven van) de ander respekteren. Het joodse integriteits-konsept is van een transcendent karakter. Het betekent een verrijking voor de huisartsgeneeskunde als zij zich dit persoonlijk-dialogisch nivo bewust wordt.

De geneeskunde loopt het gevaar, dat zij op voorhand voor zichzelf kiest en dat zij niet eerst luistert naar déze patiënt met zijn zieke of als ziek ervaren leven. Zij slaat dan de vraag over wat ziek c.q. gezond leven voor deze patiènt betekent. In het voortijdig hanteren van haar eigen weten grijpt ze over de konkrete en bijzondere levensloop van de patiënt heen. De geneeskunde hecht op voorhand door haar eigen wetenschappelijk bezit en haar ervaring - (te) veel waarde a an diagnostiek, aan de geobjektiveerde vaststelling van een klacht of probleem. De arts stelt dan te weinig het gesprek, de kommunikatie, het gezamenlijk overleg, primair. Men kan ook zeggen dat "het wat' in de geneeskunde prioriteit krijgt boven 'het hoe' en 'het wartoe' (vgl. Warmenhoven 1973,19832,35-41), terwijl 'het wat' juist in 'het hoe' en 'het wartoe' zijn be- 
vestiging vindt.

Rosenzweig wijst er in "Der Stern der Erlösung" op dat, als we over menselijk leven praten, hier nooit het leven van het lichaam of het leven van de ziel mee bedoeld kan worden, maar dat het om een eigen dimensie gaat. Leven is een gebeuren van een geheel eigen orde en de levensloop van iedere mens is een bijzonder gebeuren. "Das Leben nicht als Leben des Leibes oder der seele, sondern als etwas fir sich, das Leib und seele in sich, in sein Schicksal hineinreisst. Das Leben ist der Lebenslauf. (...). Das Eigenste des Menschen ist eben sein Schicksal. Leib wie seele hat er noch irgendwie mit andern gemein; sein Schicksal hat er für sich selber. Das eigene Schicksal ist zugleich Leib und seele, es ist das, was man 'am eigenen Leibe - erfährt'" (Rosenzweig $1921,1976^{4}, 314$ ).

Dit laatste woord, het woord "ervaring", heeft bij Rosenzweig een betekenis die verder gaat dan wat wij onder beleving of een ervaring die ons gevoel aangaat, verstaan. Het is voor hem de geintegreerde ervaring van gevoel, intuitie en verstand. Bovendien is voor hem ervaring verbonden met de levensgebeurtenissen zoals deze in de joodse traditie gestalte hebben gekregen (zie hoofdstuk 3 ) en zoals het in de ordening van het leven naar voren komt. Wat wij ervaren is niet louter een intra-psychisch gebeuren, maar het is de verbondenheid met "een buiten". Wat wij ervaren zijn werkelijke gebeurtenissen.

In het Duitse woord 'Erfahrung' zit het woord "fahren'. Dit heeft betrekking op de weg die afgelegd moet worden. Hier gaat het dan om de levensweg, de weg van de Torah. De weg van de Torah is geen weg die op zoek is naar het wezen, naar de waarheid, - die vraag is niet te beantwoorden -4 maar naar leven (zie Rosenzwe 19 1921, 1976 4,342 ).

Rosenzweig benadrukt dat 'leven' een geheel eigen dimensie kent, die wij wel ervaren, maar 
die we niet kunnen terugbrengen tot een bepaald facet. Hij wijst er in zijn boek ook op, dat dit leven eerst zin $\mathrm{krijgt}$ als we het invoegen in de gebeurtenissen uit het verleden en in de toekomst, zowel die van ons eigen leven als die van de wereld (id.,314-315). In deze zin is ons leven verbonden met de geschiedenis van de mens en met de ordening die in de gebeurtenissen besloten ligt.

Ons aan de tijd gebonden leven en onze levensloop vragen erom 'levend' gemaakt te worden (id.,320). De mens kan dit 'leven" proberen te zoeken in natuurlijke processen. Hij kan zich ook proberen open te stellen voor die ordening die niet alleen het individuele leven, maar ook de gemeenschap ordent en die in de Torah verwoord is. Rosenzweig: "Indem so die heilige Gesetzlehre - denn beides, Lehre und Gesetz in einem, umschliesst der Name Thora - das Volk aus aller Zeit- und Geschichtlichkeit des Lebens heraushebt, nimmt sile ihm auch 4 die Macht über die Zeit" (Rosenzweig 1921,19764.337).

Rosenzweig wijst dan op de levensordening van het jodendom en hij noemt de sabbat met zijn anticipatie op de eeuwige sabbat, de hoeksteen van het leven (id.,348). De Torah, Israël, is echo van de eeuwigheid, zei Heschel eens.

Een van de kenmerken van de levensloopgeneeskunde is, dat de huisarts door zijn positie als eerstelijns arts een (episodisch) kontinue en persoonlijke relatie met de patiënt heeft. Mede hierdoor is hij op de hoogte van de levensgeschiedenis van de patiënt en van de in diens leven en met betrekking tot diens gezondheid relevante data en gebeurtenissen. Dit heeft de huisarts voor op de specialist. Bovendien is de huisarts minder dan de specialist afhankelijk van een eenmalig konsult, of althans van een beperkt aantal konsulten. Deze positie houdt in, zei de bekende psychiater Michael Balint eens, dat de huisarts in feite op een goudmijn zit om de levensloop, het 'levensontwerp' en de levenssituatie van zijn pa- 
tiënten mede $\mathbb{i n}$ zijn behandeling te betrekken. De huisarts behoort te weten wat "leven" voor de patiënt betekent en wat de door de patiënt ervaren bedreigingen voor diens leven inhouden.

Hierbij is niet in de eerste plaats aan de orde of de betrokken patiënt psychosociale problemen heeft of dat lichamelijke klachten psychosoclaal van aard zijn, maar het levenslot en de levensloop van de patiënt en de betekenis hiervan is van belang - en dit in de relatie tot de klacht. De integrale benadering is er in het algemeen tezeer op gericht, op basis van de klacht waarmee een patiënt komt, te ontdekken wat het (eigenlijke) probleem is, en te ontdekken wat de samenhang is tussen fysieke, psychische en omgevingsfaktoren. In feite wordt hiermee de integriteit van de patiënt onvoldoende recht gedaan.

Veel beter is het samen met de patiënt na te gaan wat de klacht voor hem of haar betekent. Niet wat er fysiek, en ook niet wat er psychisch en sociaal aan de hand is, is voor de patiènt primair van belang, maar wat er met hem of har gebeurt. De eerste vraag is dan ook wat de patiënt bezig houdt en wat hij eigenlijk hoopt en verwacht dat de arts voor hem zal betekenen. Het behoort mijns inziens tot het goed vakmanschap van de huisarts deze zaken samen met de patiënt te verhelderen en hierbij een verband te leggen met de klachten (zie Van Aalderen e.a. $1982^{2}$; Holten-Vriesema e.a. 1978; Schouten 1982). Voor de huisarts is vooral een goede en juiste werkmethodiek van belang, een methodiek die rekening houdt met het betekenisaspekt van de klachten en die verbanden weet te leggen met de levensloop en levenssituatie van de patiënten. Ik ben stel1 ig van mening, dat dit proces van 'konsultvoering!, zoals we dit in de Maastrichtse huisartsopleiding (Van Thiel 1984) genoemd hebben, in opleiding, onderzoek en praktijk nog onvoldoende aandacht krijgen (vgl.Kimsma en Ten Have 1984). 
Een samenleving die geen raad (meer) weet met het leven en warin niet-organische, materiële, mechanische zaken een hogere waarde vertegenwoordigen dan liefde voor de medemens en de natuur of de wil werkelijk menselijk gezond te leven (zie Fromm 1982,52), weet ook niet goed om te gaan met de tijd en de ordening van het leven. Ook deze worden dan 'mechanisch' tegemoet getreden (zie RosenstockHuessy 1966).

Fromm komt met het voorstel ernstig te overwegen of het basisprincipe van de joodse sabbat in onze samenleving in praktijk gebracht kan worden op een dag van rust (zaterdag). Deze dag dient dan onderscheiden te worden van de huidige zondag die intussen vooral het sociaal-hygiënisch karakter gekregen heeft om de mens lichamelijke en geestelijke ontspanning te geven. Deze speciale dag zou de mens weer de mogelijkheid geven zijn betekenis en warde als mens te beleven, waar hij nu zijn bestaan op grote schaal als leeg en ongezond, als versnipperd en niet heel, ervaart. Fromm: "Aange-zien het in steeds toenemende mate de gewoonte wordt, dat men twee vrije dagen heeft, lijkt een dergelijk idee in geindustrialiseerde landen op zichzelf niet onuitvoerbaar. Als ik het principe van de joodse sabbat zeg, dan bedoel ik niet alle details van de joodse sabbatswet, zoals het zeifs niet dragen van een boek of een zakdoek of het niet maken van vuur. Hoewel ik geloof, dat zelfs deze details van belang kunnen zijn voor het scheppen van een volkomen atmosfeer van rust, kan men, dunkt mij, niet van de mensen verwachten - afgezien misschien van een kleine minderheid - dat zij dergelijke lastige gebruiken in acht nemen. Maar ik ben ervan overtuigd, dat het principe van de sabbatsrust overgenomen zou kunnen worden door een veel groter aantal mensen - christenen, joden en mensen, die buiten iedere religie staan. De sabbat zou voor hen een dag van contemplatie, lezen, goede gesprekken, een dag 
van rust en vreugde kunnen zijn, volkomen vrij van alle praktische en wereldse zorgen" (Fromm $1975,190)$.

Het konsept van de sabbat, en dan niet als religieus-kultische dag, mar als een dag van studie met betrekking tot het leven, zou wel eens essentieel voor onze geestelijke (volks)gezondheid kunnen zijn. Het gaat hierbij niet alleen om rust, mar ook om bezinning op het leven. En niet alleen gaat het om bezinning op het leven, maar ook om leven met elkaar in gezin en gemeenschap. Ook de studie van de Torah is in de joodse traditie lets dat men samen doet. Als onze samenleving dit voorstel van Fromm zou weten te realiseren en de steeds groter wordende vrije tijd voor een deel aan dit 'lernen' zou weten te besteden, dan is de sabbat wat zij is, namelijk 'een wereldrevolutie' (Rosenzweig 1935, 509;id.1979,Bd.2. 985), die elke willekeur 4 uit de loop van het leven halt (id.1921,1976*,342). 
HOOFDSTUK 6: "GELIEFD IS DE MENS".

6.1. Inleiding

In de vierde 'seder' (deel) van de Misjna staat een belangrijk traktaat. Het is het traktaat Pirke Avot, 'Spreuken der Vaderen'. In dit traktaat staan vele 'misjnot (leringen) die op de mens betrekking hebben en op de mens en zijn verhouding tot God, tot de medemens en tot de wereld. De joodse traditie acht de lering van dit traktaat 'Pirke Avot' van een dermate grote zeggingskracht, dat zij het in de 'siddoer', het boek met de dagelijkse gebeden, opgenomen heeft.

In het derde hoofdstuk van de "Spreuken der Vaderen' staat een 'misjna' die specifiek op de mens en zijn handelen gericht is. De beginzin hiervan luidt: "Beloved is man for he was created in the image (of God)". Het slot is als volgt "It is written: For I give you good doctrine; forsake ye not my Torah" (Mishnah, Aboth III, 15 soms 14). "Geliefd is de mens" (Aschkenasy en Whitlau 1981) - het is de mens, die in antropologisch opzicht en naar zijn handelen in dit hoofdstuk, het slothoofdstuk, aan de orde is.

over het leven van de mens en over 'de mens" kan niet alles gezegd worden (vgl.Buber 1967, 523). Het probleem war de wetenschapper onder andere mee te maken heeft, is dat de mens "geen onveranderlijke zijnstoestand" bezit, zegt Landmann. Hierdoor is het niet goed mogelijk voldoende wetenschappelijke objektivi teit in acht te nemen. Kennis nemen van de mens brengt tegelijk verandering teweeg (Landmann $1966,1972,11)$. Strasser stelt de vraag of de mens wel in staat is zichzelf tot object van wijsgerigantropologisch onderzoek te maken. Hij noemt dit het "antropologisch dilem- 
ma" warvoor de onderzoeker komt te stan (Strasser $1962,1973^{4}, 18$ ). De vraag naar de mens wordt meestal verkeerd gesteld, zegt $\mathrm{He}-$ sche1. "Even the form in which we ask the question about man is based by our own conception of man as a thing. We ask: What is man? Yet the question should be: Who is man? (Yet) the problem is not whether I function, or whether I am, but who I am" (Heschel 1965, 28).

We hebben bij Rosenzweig reeds gezien dat de joodse traditie over de eigen ard van het mens zijn zeer duidelijk is. De mens neemt een geheel eigen en aparte plaats in naast de fysieke wereld, de wereld der dingen, en naast God. En het is vanuit dit uitgangspunt dat we vanuit het weten van de joodse traditie een aantal aantekeningen zullen maken met betrekking tot de mens en zijn handelen.

Met dit latste is ook het patroon van dit hoofdstuk vastgelegd. In een eerste deel ga ik in op de vraag naar het beeld van de mens in de joodse traditie. Daarna besteed ik aandacht aan de weg die de mens heeft te gaan. Ik spits dit toe op de geneeskundige situatie Tenslotte plaats ik in het laatste deel het handelen van de mens in het perspektief van het eindpunt van alle menselijk handelen, terwijl ik in een slotparagraaf de vraag naar de mens in het perspektief tracht te plaatsen van de grondslag van het leven en van de weg van het leven.

$\frac{\text { 6.2. Het beeld van de mens in de joodse }}{\text { traditie. }}$

6.2.1. Geschapen naar Gods beeld, naar zijn gelijkenis.

Het jodendom heeft een antropocentrische kijk 
op de wereld. "Man is the centre and measure of existence" (Cohon 1971,286). Heschel noemt de Torah een boek dat over de mens gaat. "Het is geen theologie vanuit het gezichtspunt van de mens, maar meer een antropologie vanuit het gezichtspunt van God" (Heschel in De Bruin 1983,$45 ;$ id. 1960,$\left.113 ; i d .1955,1976^{3}, 412\right)$.

De kern van het jodendom is, zegt Heschel. "het bewustzijn van de wederkerigheid van God en de mensen". God is met de mens verbonden en "het besef van een verbond, het besef van God"s belangstelling in de mens", is de enige manier om het jodendom te omschrijuen (id.,5455). Nu valt er over God moeilijk iets te zeggen, maar wel over $\mathrm{zijn}$ Torah en over wat hierin over de mens wordt gezegd. Niet voor niets zet Levinas boven een van zijn artikelen: "Meer van de Thora houden dan van God" (Levinas $1969,1971^{2}, 55$ ).

Gods verbondenheid met de mens en de speciale positie van de mens (antropocentriciteit) komt in de Torah al direkt in het verhaal van de schepping naar voren: "Machen wir den Menschen in unserem Bild, nach unserem Gleichnis" (Im Anfang 1,$26 ; G e n .1: 26)$. Uit het verhaal van de schepping blijkt dat de schepping van de mens iets bijzonders is. De mens is schepsel en de schepping van de mens is het kulminatiepunt van de scheppende arbeid van God (vgl.Cohen 1932,72 ).

Dat de mens naar het beeld van God, op Hem ge1 ijkend, geschapen is, is een belangrijk gegeven in de joodse traditie (Enc.Talm. Vol.1 203-204; Cohen 1932,72; Epstein 1954,19806,209210). Ik kom op de betekenis hiervan nog terug. Van belang is verder, dat de mens schepsel is en dat hij van al het geschapene als laatste geschapen is. Dat de mens 'schepsel' is, houdt in dat de mens, evenals het andere dat 'schepping" (Rosenzweig) is, 'goed" is. "Gott sah", maakt de Torah ons bekend, "dass es gut ist" (Im Anfang 1,10-31;Gen.1:10.31).

Als God dan ziet wie Hij geschapen heeft, zegt hij niet dat het goed is, mar, zo leert de 
Torah, op dat moment spreekt Hij zelfs over "zeer goed" (Gen.1:31). "All our Rabbis said the following in $R$. Hanina's name, while $R$. Phinehas and $R$. Hilkiah said it in $R$. Simeon's name: Me'od is identical with adam (man), for the letters of both are identical. Thus it is written. "And God saw every thing that He had made, and, behold, it was very (me'od) good', i.e., and behold, adam (man) was good" (Midrash Rabbah, Gen.R.IX,12). In het Hebreeuws wordt aan een dergelijke woord- of letterverwantschap dikwijls betekenis toegekend. Hier worden overigens de betreffende medeklinkers verwisseld.

Het mens zijn heeft, evenals al het andere dat geschapen is, een eigen mat. Het leven van de mens is begrensd. De mens heeft ook weet hiervan. Daarom kon Rosenzweig zijn hoofdwerk 'Der stern der Erlösung" ook met deze woorden openen: "Vom Tode, von der Furcht des Todes, hebt alleg Erkennen des All an" (Rosenzweig 1921. $\left.1976^{4}, 3\right)$. Maar, omdat hij kon vertrouwen op iets dat zonder mat is kon hij zijn boek afsluiten met de openende woorden "ins Leben" (id.,472). "Everything has a measure, haven and earth have a measure, except one thing which has no measure: and what is it? The Torah" (Midrash Rabbah, Gen.R.X, I).

Er is nog een tweede versie van de schepping van de mens in de Torah te vinden: "Und ER, Gott bildete den Menschen, Staub vom Acker,

er blies in seine Nasenlöcher Hauch des Lebens, und der Mensch wurde zum lebenden Wesen" (Im Anfang 2,7 8; Ger. 2:7-8).

Hier wordt de mens beschreven als gevormd uit het stof van de aarde. Heschel zegt over deze tweede versie: "Beeld en stof drukken beide de polariteit uit van de aard van de mens. Uit de nederigste materie is hij gevormd tot het hoogste beeld. De polariteit van de mens hoeft geen onontkoombare tegenspraak te behelzen. Er schuilt zelfs betekenis en zegen in het feit 
dat hij gevormd is uit het stof der aarde. Want alleen dardoor kan hij zijn opdracht vervulien om de aarde te bebouwen en te bewaren. Maar hoewel de dualiteit van de menselijke aard geen onoplosbare tegenspraak herbergt, houdt zij wel een spanning in tussen grootheid en nietigheid; een verbondenheid zowel met de aarde als met God" (Heschel, in De Bruin 1983, 70).

Heschel wijst erop, dat de mens uit de aarde gevormd is, mar op een geheel andere wijze dan de dieren. Stof is het einde van de mens. Stof is ook het einde van het dier. Maar toch is er een verschil tussen beiden. "Planten en dieren werden voortgebracht door de arde, door de wateren (Gen.1:11,20,24). Ze ontstonden uit de "natuur" en werden tot 'organisch" deel van de natuur. In de taal van het tweede Genesis-hoofdstuk werd ieder dier van het veld en iedere vogel van de lucht, gevormd uit de bodem. De mens is evenwel niet gemakt uit de bodem die de bron is van alle plantaardige en dierlijke leven; en evenmin uit het water, dat symbool staat voor verfrissing, zegen en wijsheid. Hij werd gevormd uit droge stof, het stof van de woestijn, tegelijkertijd waardeloos en overvloedig (Zefanja 1,17; Zacharia 9,3; Job 22,24)" (Heschel, in De Bruin 1983, 72).

De mens is dus tweevoudig gebonden. Aan de tweevoudige gebondenheid ligt het scheppend handelen van God ten grondslag (vgl. Rosenzweig 1979, Bd.2,824-827). Door deze tweevoudige gebondenheid heeft het mens zijn een geheel eigen dimensie. "Both Adam and the beasts were blessed by the Lord, but man was also charged with conquering the earth and dominating the beast. Man is always faced with the cholce of listening either to God or to the snake. It is always easier to envy the beast, to worship a totem and be dominated by it, than to hearken to the Voice" (Heschel 1960,116). Alleen de mens is tot luisteren, tot kiezen, tot bewust en vrij handelen in staat. 
De mens is anders dan de natuurlijke orde van de dingen, de planten en de dieren. "De mens gat boven de natuurlijke orde der dingen uit" (Levinas $1969,1971^{2}, 35$ ). Ook Rosenzweig geeft in 'Der Stern der Erlösung' aan dat de mens iets is van een geheel eigen orde en dat de mens in de bijzonderheid van zijn levensioop en zijn zelf-ervaring onderscheiden moet worden van de wereld der dingen (zie Rosenzweig $1921,19764,67-90$; id., 314). Heschel: "Man is man not because of what he has in common with the earth but because of what he has in common with God" (Hesche1 1959,1975,152).

Het geschapen zijn naar Gods beeld wil niet zeggen dat de mens uiterlijk op God zou gelijken. Het wil ook niet zeggen dat God op de mens zou lijken of dat God zoiets als een andere naam voor het oerbeeld van de mens zou zijn. "God is qivine and man is human" (Hesche1 $1959,1975,151$; zie ook Rosenzweig 1937, 378). De God van Israël is een God zonder beeld. "Wanneer wij met het anthropomorfisme zo ver zouden gaan, dat wij ons God als het oerbeeld van de mens, dus in menselijke gestalte, zouden voorstellen, zou daarmee een heilloze breuk met de bijbelse geloofswereld voltrokken zijn" (Ben-Chorin 1973,10).

Rosenzweig heeft in zijn hoofdwerk gezegd, dat voor de mens (onder andere) kenmerkend is, dat hij de vrijheid bezit om te handelen (zie hoofdstuk 2). De mens kan iets wel of niet willen en ernaar handelen. Dat de mens geschapen is naar Gods beeld en gelijkenis, wil zeggen, dat de mens evenals God gekenmerkt wordt door zijn daden. Weliswaar bezit de mens niet de 'oneindigheid van macht' die God eigen is. Het handelen van de mens is beperkt, maar juist in het felt van het handelen zelf ligt de gelijkenis. "The idea of man having been created in the limage of God was interpreted. it seems, not as an analogy of being, but as an analogy of doing. Man is called upon to act 
in the likeness of God" (Heschel 1959,1975", 160-161).

De Italiaanse arts Shabbatai Donnolo, die leefde van 913 tot ca. 982, gaf op de volgende wijze uitdrukking an wat het wil zeggen dat de mens op God gelijkt: "As God is supreme and rules over man and over all the world, beneath and above, so is man; as God knows and discerns things that happened and foresees things to come, so man, whom God has granted wisdom to know; and as God supplies and gives food to all flesh, so does man sustain all the members of his household, his attendants, and his animals; and as the creator built the world and laid the foundations of the earth, stretched the heavens and gathered the waters together, so man is able to build, to found, and to call and gather together, to sow, to make grow, to plant and to do (...) and in most things man is likened in small measure to God, in accordance with the limitations of the strength and the short span of the 1 ife ${ }_{6}$ which God has given him" (in Epstein 1954,1980',210211).

Geschapen zijn naar Gods beeld en gelijkenis wil zeggen dat de mens niet God is en evenmin God kan worden, zegt Fromm, "maar hij kan worden als God, hij kan God als het ware imiteren. En dit idee van de imitatio dei, van het God benaderen, is alleen denkbaar als men vooropstelt, dat de mens gemakt is naar Gods beeld" (Fromm 1975,50). Heschel bedoelt iets dergelijks als hij zegt: "Treat thyself as an image of God" (Heschel 1959,1975, 156).

Rosenzweig noemt dit handelen als God het eerste wat de mens te doen stat. Hij sluit dan aan bij Micha 6,8 waar staat: "Recht tun und von Herzen gut sein und einfältig wandeln mit deinem Gott" Alleen dit handelen als God leidt "ins Leben" (Rosenzweig 1921,1976",471.472). 'Imitatio Dei' zo zegt de Torah, wil zeggen: "IHM eurem Gott gehet nach, ihn firchtet, seine Gebote wahrt, auf seine stimme hört, 
ihm dienet und haftet an ihm!"

(Reden 13,4; Deut.13:4).

Van Boxel attendeert erop dat het in de joodse traditie niet zozeer om liturgie gaat, maar om ethiek: "Je zult achter de Heer je God aanwandelen" (Van Boxel 1982,36). Hij citeert dan de Talmoed waar de rabbijnen Deuteronomium 13, 45 interpreteren. De vraag die gesteld wordt, is hoe men achter God kan aanwandelen. Hij is immers als een verterend vuur! (Deut.4:24). De betekenis van deze tekst is echter, dat men zich moet gedragen als God. Zoals God de naakten gekleed heeft (Gen.3:21), zo behoort ook de mens dit te doen. De rabbijnen geven dan meerdere voorbeelden, zoals het eerder genoemde bezoeken van de zieken, het bijstaan van de rouwenden en het verzorgen en begraven van de doden (Bab.Talm., Sotah 14a).

Het bijbels verhaal van de schepping van de mens geeft ons twee belangrijke lessen: "the personal value of each individual, of each human being (God created only one man and hence every human being is a whole universe). and the unity of the human race (all men have one and the same father)" (Gottlieb 1979,53). Dit laatste moet echter niet verstaan worden alsof God het oerbeeld van de mens is (zie hiervoor; Ben-Chorin 1973,10). De warde van ledere individuele persoon wordt zo hoog geschat, dat de Misjna een verband legt met de wereld als geheel. "Therefore but a single man was created in the world, to teach that if any man has caused a single soul to perish Scripture imputes it to him as though he had caused a whole world to perish; and if any man saves alive a single soul scripture imputes it to him as though he had saved alive a whole wor 1d "(Mlshnah, Sanhedrin IV,5;zie ook ARN XXXI, 125).

De persoonlijke warde van ieder individu houdt in dat er geen verschil is tussen (het handelen van) lemand van het ene ras boven dat van iemand van het andere ras. "De verschilien 
die er tussen individuele personen, groepen mensen en volkeren bestaan, doen niets af aan de fundamentele gelijkwaardigheid van alle mensen (zie Mishnah, Sanhedrin IV,5), (...). Ondanks de niet te loochenen intellectuele en fysieke verschillen (..), zijn alle mensen gelijkwaardig, omdat een ieder geschapen is naar het beeld van God" (Abram 1980,120).

De mens die is als God, gat de weg van de Torah, en door de weg van de Torah te gaay is de mens "Gods partmer" (zuidema 1977,1982, 9; Heschel $1959,1975,152 ;$ id.,1960,128; vgl.Enc. Jud., Vol.11,844). "Life is a partnership of God and man" (Heschel 1959,1975,160). "Het betekent tegelijkertijd God kennen. (...). In de traditie van de $B i j b e l$ tot Maimonides betekent 'God kennen' en 'als God zijn' Gods handelen navolgen en niet kennis dragen van of speculeren over Gods wezen" (Fromm 1975,52). Kennis dragen van Gods handelen en van Gods bedoeling met het leven gebeurt door de studie van de Torah. "It is a privilege for man to have been created by God's image', says Rabbi Akiba, but it is a still greater privilege for him to have been able to learn that he has been created by God, and in God's image" (bij) Gottlieb $1979,52-53$ ).

6.2.2. Handelen in vrijheid.

Een van de belangrijkste dingen wardoor de mens een geheel eigen positie inneemt is zijn vrijheid tot het doen van keuzen. Menselijk leven houdt een nooit eindigende opdracht om te kiezen in (Fromm 1982,144-145). De mens kan het één doen of het ander. Hij kan iets wel of iets niet doen. De grondslag van deze vrijheid van wil valt te lezen in het Torah-verhal over het gebeuren in de hof van Eden:

"ER, Gott, gebot uber den Menschen, sprechend: Von allen Bäumen des Gartens magst essen du, essen, 
aber vom Baum der Erkentnis von Gut und Bóse. von dem sollst du nicht essen"

(Im Anfang 2, 16-17; Gen. 2:16-17).

"In a supreme act of self-limitation the Absolute God gave man freedom of moral choice. He could will to do right or wrong, to obey or disobey his maker. It was heaven's greatest gift to man: he was not to be an automaton" (Enc.Jud. "Vol.11,844).

Deze aan de mens gegeven vrijheid van keuze voor het goede of voor het slechte pakte verkeerd uit. De mens rebelleerde tegen zijn schepper. Dit $\mathrm{kreeg}$ reperkussies in alle volgende generaties met als dieptepunt de dans om het gouden kalf (Gen.32). "There is no generation in which there is not an ounce from the sin of the Golden Calf", citeert Cohen uit de Talmoed (Cohen 1932,102).

De rabbijnen beschouwen zonde als rebellie tegen God. "He has revealed His will in the Torah and to run counter to any of its ordinances is transgression. Virtue is conformity to the Torah; sin is its disregard" (Cohen 1932,102).

Van al het geschapene bezit alleen de mens de vrijheid iets wel of lets niet te willen. Deze vrijheid van wil is, zo zegt Epstein, "intellectual and determined by reason" (Epstein $\left.1954,1980^{6}, 215\right)$. Epstein sluit hiermee aan bij twee eigenschappen die, zo zeggen de rabbijnen, aan de mens toebedacht zijn: 'chokma' (wijgheid) en 'bina" (begrip). Alleen de mens is in stat bewust van zijn ervaringen te leren en wijoheid te verzamelen en alleen de mens bezit de bekwaamheid het ene ding van het andere te onderscheiden, het te benoemen en ervoor of ertegen te kiezen.

Toen Mozes aan het volk Israel de Torah voorlegde, antwoordde het volk: "Alles, was ER geredet hat, wir tuns, wir hörens!" (Namen 24, 7:Ex.24:7). Er is een miarasj die zegt, dat God met de Torah de volkeren afging. Niemand echter wilde haar hebben, behalve Israël dat haar in vrijheid aksepteerde (Midrash Rab- 
bah,Ex.R., XXVII,9). De (studie van de) Torah betekent geen dwang voor de mens, maar vrijheid (Mishnah, Aboth VI, 2). "Daar waar de Torah in liefde vervuld wordt, wordt ze niet als dwang ervaren" (Ben-Chorin 1973,54).

Het principe dat de vrijheid van wil karakteristiek is voor de mens geeft de mens de opdracht te kiezen tussen goed en kwaad, "tussen leven en groei enerzijds en dood en stagnatie anderzijds" (Fromm 1982,124;Midrash Rabbah,Gen.R.VIII,1I). En ieder mens kan daarom ook zijn eigen weg in het leven kiezen (Kaplan 1979,27). De weg van de mens is echter geen weg meer waar, zoals in de hof van Eden, een harmonie tussen de mens en de wereld, de mens en de medemens en de mens en God bestaat. sinds de rebellie van de mens heeft hij weet van het kwade in de wereld. "Man is free to act in freedom and free to forfeit. (...). We are free to choose between good and evil; we are not free in having to choose" (Heschel $\left.1955,1976^{3}, 412\right)$.

De Miranda wijst erop dat er twee soorten kwaad in de wereld bestaan, - "kwaad dat in onze hedendaagse wereld bestreden moet worden". De eerste soort is dat kwaad, dat teweeg gebracht wordt als iemand zijn doen en laten afhankelijk laat zijn van zijn stemmingen, van zijn 'zin' op dat moment. Zowel het goede als het slechte zijn bij iemand die zo in het leven staat afhankelijk van stemmingen, van 'invallen'. Diens gedrag heeft daardoor lets toevalligs en het goede, maar ook het kwade, berust op willekeur. De tweede soort is dat kwaad, dat moedwillig bedoeld is, dat het doen van het kwade c.q. "het doen-lijden tot het doel van iemands leven heeft gemaakt", omdat, zo citeert Miranda Dírrenmatt, "Das Böse seine Moral, seine Philosophie darstellt". De Miranda noemt zo iemand "gewetenloos", dat wil zeggen iemand "voor wie het onderscheid tussen goed en kwaad is weggevallen", omdat hij het kwade "net zo fanatiek nastreeft, als een 
ander het goede" (De Miranda 1983,59).

De joodse traditie onderkent goede en kwade drijfveren in de mens (zie o.a. Schechter $\left.1909,1975^{5}, 66-68\right)$. De goede drijfveer tot handelen, de intentie en gerichtheid juist en goed (rechtvaardig) te handelen, is de 'jetser ha-tov', letterlijk: de goede drijfveer. De slechte drijfveer is de "jetser ha-ra". "The Holy One, blessed be He, created two impulses, one good and the other evil" (Bab.Talm., Berakot 61a). Het is van het grootste belang dat de mens ook deze 'jetser ha-ra' plaatst binnen het uitvoeren van Gods plannen, dat hij deze kwade impulsen dus ten goede aanwendt. Dit bevordert ook de geestelijke gezondheid, de gaafheid van de mens. "The character of a person is determined by which of the two impulses is dominant within him" (Cohen 1932, 94). De mens die overwegend goede keuzen makt is een gaaf, een (geestelijk) gezond mens. "The wicked are under the control of their heart (i.e. their evil impulse), but the righteous have their heart under their control" (Midrash Rabbah,Gen.R.XXXIV,10).

De juiste manier on met de "jetser ha-ra" om te gaan is haar niet te onderdrukken of te doden. Dit lukt immers toch niet. Bovendien: de 'jetser ha-ra' is ${ }_{5}$ ook door God geschapen (Schechter $1909,1975^{5}, 66-68$ ). Zoals al het andere dat geschapen is, is de 'jetser ha-ra' goed. Het is an de mens er een juist gebruik van te maken, niet ten kwade, maar ten goede. "Consequently it is not something so far as it is 1iable to be misused" (Cohen 1932,96). De Talmoed noemt de 'jetser ha-ra' ook wel "het zuurdesem in het deeg" (Bab.Talm. Bereshit 17a). Dit zuurdesem is altijd aanwezig, mar

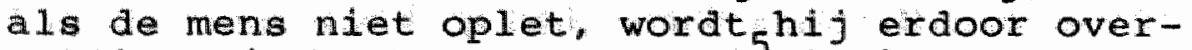
weldigd. (Schechter $1909,1975^{5}, 248$ ). "Een verkeerde dosering van het zuurdesem bederft het gistingsproces, maar zonder het zuurdesem is het deeg smakeloos", zegt Abram (Abram 198,132) Op dezelfde wijze als met het zuurdesem omge- 
gaan moet worden (dit heeft immers een funktie), op dezelfde wijze moet de mens de "jetser ha-ra" aksepteren en gebruiken. "Man has the power in his own hands, and it is only by man"s own neglect and weakness that the 'evil yezer", who appears first quite effeminate and powerless, gains masculine strength, enabling him to dictate man. If man does well, he finds forgiveness; but if he does not well, he is delivered into the hands of the 'evil yezef' who lies at the door" (Schechter 1909,1975". 270).

Goed en kwaad liggen als twee polen in de menselijke aard besloten, zegt De Bruin. En de mens moet een keuze daartussen doen. "Goed en kwaad zijn met elkaar vermengd; er bestaat ook geen absoluut goed of absoluut kwaad. De mens heeft de opdracht om het goede en het kwade te ontwarren. Dat is ook wat de joodse traditie "verlossing" noemt, nl. scheiding aanbrengen tussen goed en kwaad. De Torah dient daarvoor als programma, de halacha (normatieve leefregels) en de mitswot (opdrachten) zijn daarbij de dagelijkse leidraad" (De Bruin 1983, $38)$.

Als we scheiding aanbrengen tussen goed en kwaad is dit iets wat we in konkrete situaties doen. De werkelijkheid van alledag verlangt steeds weer dat we kiezen. Daarbij gaat het niet om de keuzen die men zou kunnen maken, maar om de keuzes die men werkelijk makkt (Abram 1980,122). Kiezen voor het goede wil niet zozeer zeggen kiezen voor het goede als een abstrakt iets, maar kiezen voor een richting, een weg in het leven die we te gaan hebben (vgl.Buber, bij De Bruin 1983,252). Het is kiezen voor het ten goede gebruiken zowel van de 'jetser ha-tov" als van de 'jetser ha-ra'.

Als remedie tegen de 'jetser ha-ra' noemt Schechter: "Occupation with the study of the Torah and works of loving-kindness" (Schechter $\left.1909,1975^{5}, 273\right)$. Als de mens zich met de studie van de Torah bezighoudt en handelt volgens 
dit plan, dan kan de mens de "jetser ha-ra" beheersen. In sommige kringen is het gebruikelijk psychosociale c.q. psychiatrische problematiek aan te pakken door studie van de Torah. (persoonlijke mededeling B. Maoz, Beer Sheva). De therapeut leert dan samen met de hulpvragende in een "relatie van sympathisch partnerschap" (Abram 1980,249-257). De Talmoed zegt: "A man should always incite the good impulse (in his soul) to fight against the evil impulse. For it is written: Tremble and sin not (Ps.IV,5). If he subdues it, well and good. If not, let him study the Torah" (Bab. Talm. Berakoth 5a).

De mens die de "jetser ha-ra" beheerst en ten goede gebruikt is ook een vrij mens. Zo lemand kiest telkens weer voor zijn eigen vrijheid. Mar, "de mens moet $z i j n$ vrijheid leren uitoefenen", zegt Abram, "hij moet leren te kiezen en hij kan dit leren door de Torah te bestuderen" (Abram 1980,129;vgl.id.,226-227).

Vrijheid van keuze betekent niet dat het onverschillig is welke keuze de mens makt:

"Sieh,

ich gebe heuttags vor euch hin segnung und Verwinschung,

die segnung, wofern ihr hört auf SEINE eures Gottes Gebote, die ich heuttags euch gebiete, die verwinschung, hört ihr nicht auf SEINE eures Gottes Gebote.

weicht inr $a b$ vorn Weg, den ich heuttags euch gebiete" (Reden 11,26-28; Deut.11:26-28).

Er is geen tussenweg mogelijk. Kiezen gebeurt of fout of goed, mar nooit 'neutraal'. De keuze is altijd beslissend: zij is gezond of ongezond. $2 i j$ makt de mens beter of ziek. $\mathrm{zij}$ leidt tot leven of $\mathrm{zij}$ werkt vernietigend. Het gaat er dan ook om het betere te kiezen, dat te kiezen dat ons een gezonder mens makt. Fromm: "Vrijheid is niets anders dan het kunnen luisteren naar de stem van rede, gezondheid, welzijn en geweten tegenover de lokroep van irrationele passies" (Fromm 1982,123). Israël makkte de keuze "whole Jews" te zijn 
(vgl.Abram 1980,219).

"Sieh,

gegeben habe ich heuttags vor dich hin das Leben und das Gute,

den Tod und das Böse"

(Reden 30,15: Deut.30:15).

"Das Leben und den Tod habe ich vor dich hin gegeben,

die segnung und die Verwinschung, wähle das Leben" (id.,30,19).

Vrijheid is een belangrijk thema in het werk van de al eerder genoemde joods-humanististische denker Erich Fromm. Fromm had in Frankfurt am Main Franz Rosenzweig leren kennen en er deelgenomen aan het werk van het Leerhuis. Hij studeerde in die tijd sociologie en psychologie in zijn geboortestad Frankfurt. In Heidelberg makte hij kennis met de psychoanalyse. De groep waarvan Fromm deel uitmaakte, bestond uitsluitend uit joden. Dit was de reden, dat in plaats van 'Therapeutisch Praktikum' met een grapje ook wel van 'Thorapeutisch Praktikum' gesproken werd. Fromm zou, vermengd met zijn joods-bijbelse achtergrond, zijn hele leven lang zijn scholing in de psycho-analyse blijven toepassen. Hij is een goed voorbeeld van een synthese tussen het joodse en het westerse weten.

Door te eten van de boom van kennis van goed en kwaad is de oorspronkelijke harmonie tussen mens en natuur verbroken, geeft Fromm aan. De mens heeft hiermee zijn oorspronkelijke verbondenheid met de natuur doorgesneden en hij begint aan het proces van individuatie. De mens moet echter niet alleen de banden met de natuur doorsnijden, maar ook de band met zijn vader en moeder, zoals uit Genesis $2: 24$ blijkt. De volgende stap is, dat de mens ook alle banden die hem tot slaaf maken, doorsnijdt. Abram trok weg lit zijn land (Gen.12:1) en veel later alweer bevrijdde de groep Hebreeën zich uit de slavernij en afgodendienst van Egypte. Vrijheid wil zeggen dat de mens zich van de 
incestueuze banden van bloed en bodem bevrijdt en dat hij zich van elke wereldse dwang en macht bevrijdt. Onvrij is de mens die aan de natuur (c.q. aan zijn eigen lichaam) gefixeerd is en die gefixeerd is aan zijn sociale ongeving. "Fixatie is een emotionele binding die de mens affectief aan een ander bindt" (Fromm $1975,56)$.

Fromm onderscheidt fixatie van gehoorzaamheid. Gehoorzaamheid is een bewuste daad; het is eerder een gedrag dan een gevoel. De mens die God gehoorzaamt, wil daarmee uitdrukken, dat hij onathankelijk is van elke menselijke autoriteit (id.,57;Micha 6:8;Bab.Talm., Sotah 14a). De stap die de joodse traditie vervolgens makt, is dat de bijbelse eis tot gehoorzaamheid aan de vader ontwikkeld wordt tot een punt "war de bloedverwantschap met de vader ondergeschikt geworden is an de geestelijke verwantschap met de leraar" (Fromm 1975,58; vg1.Mishnah, Baba Metsia II, 11). In de joodse traditie, zoals die zich in de mondelinge Torah als leertraditie ontwikkeld heeft, wordt God niet zozeer als vader, maar als leraar gezien. Dat God schepper, 'openbarer' en verlosser is (vgl.Rosenzweig $1921,1976^{4}$ ) wil zeggen dat God Schepper, leraar en verlosser is (Peli 1983, 7, Hartman 198, $\overline{82-10}$ ).

Stap voor stap werkt Fromm uit wat zijns inziens het doel is van de menselijke ontwikkeling, namelijk vrijheid en onathankelijkheid. Het is deze vrijheid die in ieder mens in beginsel aanwezig is, maar die hij moet leren ontwikkelen en in ledere situatie opnieuw weer warmaken. Vrijheid is geen eigenschap, maar iets dat gerealiseerd moet worden. "Freedom is not a continual state of man, (...). It is not, it happens. Freedom is an act, an event" (Hesche1 $1955,1976^{3}, 411$ ).

Alleen de mens die onafhankelijk is van incestueuze banden, is in staat om werkelijk in vrijheid te kiezen. Deze onafhankelijkheid wil niet zeggen dat de mens geIsoleerd is van zijn medemensen en van de wereld en ook wil zij 
niet zeggen dat de mens vrij is van God in de zin van dat er geen God zou zijn. Integendeel: God is en $\mathrm{Hij}$ beleeft vreugde an een vrij en onafhankelijk menselijk gedrag. Fromm verwijst in dit verband naar een talmoedisch verhaal warin de wijzen in een vurige discussie verwikkeld zijn. Toen Rabbi Eliëzer hierbij een beroep op de hemel deed, klonk daarop een hemelse stem. Maar zijn gesprekspartner Rabbi Joshua sprong op en zei: "Het is niet in de hemel' (Deut.30:12). Rabbi Jeremia verklaarde dat hiermee bedoeld was, dat de Torah reeds op de berg Sinai gegeven was en dat men op hemelse stemmen geen acht hoeft te slaan. Alleen de stemmen van de aanwezigen tellen (Ex.23:2). Dit verhaal eindigt dan hiermee dat Rabbi Nathan eens de profeet Elia ontmoette en hem vroeg wat de Heilige, gezegend zijHij, op dat uur deed. Elia antwoordde: Hij glimlachte en zei: mijn zonen hebben mij verslagen, mijn zonen hebben mij verslagenl "(Bab.Talm., Baba Metsia 59b;zie Fromm $1975,59-60$ ).

6.2.3. Verantwoordelijk zijn.

De mens kent niet alleen "vrijheid van will", maar $h i j$ is ook verantwoordelijk voor zijn leven, voor dat van anderen en voor de keuzes die hij makkt. Vrijheid en verantwoordelijkheid horen bij elkaar. Vrijheid zonder meer loopt het gevar van willekeur wanneer zij niet samengaat met verantwoordelijkheid (Frank1 1978,161).

Dat de mens geschapen is naar Gods beeld, naar zijn gelijkenis, legt de mens ook verantwoordelijkheid op zijn schouders. "Van een wel heel bijzondere liefde getuigt het dat Hij de mens te kennen heeft gegeven ( $\mathrm{n}$. door de Torah) dat hij naar zijn beeld geschapen is" (Misjna, Avoth III, 14). Bij de bespreking van deze tekst zeggen Aschkenasy en Whitlau: "Dat betekent dat de mens nu ook beseft dat er iets 
van hem verwacht wordt. Dit besef is bij alle individuele mensen, bij alle volken en kulturen, war en wanneer ook ter wereld, antoonbaar aanwezig" (Aschkenasy en Whitlau 1981. 20).

Evenals vrijheid is verantwoordelijkheid geen algemene, statische kwalifikatie, mar een handeling die telkens weer wargemaakt moet worden. "Verantwortung ist nie etwas Abstraktes (...), sondern immer", zo drukt Wisser dit uit, "die verlegenheit des wirklichen Mensen im Geschehen" (Wisser 1967,7). Verantwoordelijk zijn is zich door de konkrete situatie aangesproken weten en zich dan niet terugtrekken en verbergen, maar antwoorden. Toen Eva en Adam de vrucht van de boom van kennis van goed en kwaad gegeten hadden, verborgen zij zich voor God om zo geen rekenschap te hoeven afleggen voor wat ze gedaan hadden. Maar God riep Adam en zei: "Waar ben je?" (Gen.3 9). Het is deze vraag die ten alle tijde en telkens, in alle situaties weer aan de mens gesteld wordt: 'Adam, mens, waar ben je?' Martin Buber: "Om de verantwoording voor het geleefde leven te ontlopen wordt het bestaan zelf tot een schuilplaats gemaakt. En terwijl de mens zich zodoende voor het 'aangezicht Gods" verbergt en telkens weex opnieuw verbergt, raakt hij steeds dieper in het verkeerde verstrikt. Zo ontstaat er een nieuwe toestand, die van dag tot dag, van schuilhoek tot schuilhoek voortdurend onzekerder wordt. Deze toestand kan nauwkeurig gekenmerkt worden: de mens kan aan het oog Gods niet ontkomen, maar terwijl hij tracht, zich er voor te verbergen, verbergt hij zichzelf" (Buber $1968,9)$.

Het verhaal van Adam krijgt een vervolg als Abram aangesproken wordt en gevraagd wordt weg te gaan van zijn "bodem" en te vertrekken naar een land dat hem gewezen zal worden. Abram nam de verantwoordelijkheid hierin voor $z i c h z e l f$ en zijn familie op zijn schouders en vertrok (Gen. 12:1-4). 
Als nog weer later Abrahams nakomelingen in Egypte terecht gekomen zijn en zij in Egypte onderdrukt worden, onder slavernij zuchten en het uitschreeuwen van ellende ( $\mathrm{Ex} \cdot 2: 23)$, wordt Mozes bij een braambos in de woestijn aangesproken. Het antwoord van Mozes is: "Hier ben ik" (Ex.3:4). Het vervolg is bekend: Mozes neemt de verantwoordelijkheid op zich on de Israëlieten uit Egypte te bevrijden en hen door de woestijn te begeleiden. "To be is to stand for", zegt Heschel en hij geeft hiermee duidelijk an dat mens zijn wil zeggen 3 verantwoordelijk zijn (Hegchel 1955,1976 413 ; vgl.Rosenzweig $\left.1921,1976^{4}, 195-196\right)$.

Met Mozes begint de geschiedenis van het volk Israel dat in de woestijn de verantwoordelijkheid voor de Torah op zich heeft genomen. "The decisive thought in the message of the prophets is not the presence of God to man but rather the presence of man to God": het "hier ben ik' van Mozes en het 'wij zullen doen en horen' van het Volk Israël. "This is why the Bible is God's antropology father than man's theology" (Heschel 1955,1976 ,412).

Een Chassidische vertelling: "Toen Rabbi Sjneur Salman, de raw (rabbi) van Reussen, in Petersburg gevangen zat, omdat zijn inzichten en zijn weg door een leider van de mitnagdim (tegenstanders, bestrijders van de chassidische beweging) bij de regering waren zwart gemaakt, en op het verhoor wachtte, kwam de overste van de gendarmerie in zijn cel. Het groots en kalm gezicht van de raw, die hem eerst, verzonken in zichzelf als hij was, niet bemerkte, liet de nadenkende man vermoeden, van wat voor soort zijn gevangene was. Hij kwam met hem in gesprek en bracht al gauw verschillende vragen naar voren die bij hem bij het lezen der schrift waren opgekomen. Tenslotte vroeg hij: Hoe moet dat worden opgevat, dat God de alwetende tegen Adam spreekt: waar ben je? Gelooft gij, sprak de raw op zijn beurt, dat de schrift eeuwig is en 
iedere tijd, ieder geslacht en iedere mens daarin besloten zijn? Ik geloof dat, zei hij. Goed, sprak de tsaddik, in ledere tijd roept God elk mens toe: Waar ben je in de wereld? Zoveel jaren en zoveel dagen van het getal dat je is toegemeten zijn al voorbij, hoever ben je intussen in je wereld gekomen? zo ongeveer spreekt God: zesenveertig jaar heb je geleefd, war sta je ongeveer? Toen de overste het getal zijner levensjaren hoorde noemen hield hij zich goed, legde de hand op de schouder en riep: bravol Maar zijn hart beefde" (Buber $1967,289)$.

In het middelpunt van de joodse opvatting omtrent de weg van de mens staat de ommekeer (Buber 1968,39): "Turn away from evil by doing good" (Reb Shlomo of Karin, bij Heschel 1973, $\left.1977^{3}, 39\right)$. Het woord van de Torah, dat aan de ommekeer ten grondslag ligt, luidt: "da du ja umgekehrt bist, auf SEINE stimme hörst" (Reden 30,8, Deut. $30: 8$ ).

Het Hebreeuwse woord voor ommekeer is 'tesjoeva'. 'Tesjoeva' betekent echter niet alleen 'ommekeer', het betekent ook 'antwoord' (Heschel $\left.1955,1976^{3}, 141\right)$. Ommekeer in de betekenis van antwoord wil zeggen, dat het gat om een antwoord aan een konkreet iemand. Gevoelens van spijt, berouw en boetedoening zijn nog geen 'tesjoeva'. Er is dan sprake van een op elgen persoon gericht gebeuren en niet van een dialogische beweging warin de mens zjch tot de ander richt (vgl.Buber 1958,1977 ). "Doe ons terugkomen in volledige omkeer tot voor je aangezicht", staat in het Achttiengebed (E1ke Morgen Nieuw 1978,79,189).

'Tesjoeval is niet alleen een innerlijk lets of lets dat tussen God en de mens zou bestaan, mar het is ook altijd een sociaal gebeuren. Als je iemand lets hebt aangedaan of ook als je lets nagelaten hebt, ben je verplicht je tot de betrokken ander te wenden. Je behoort zowel de ander vergeving te vragen als, vooral ook, het goed te maken. 'Tesjoeva' houdt dan terugkeer tot de juiste weg, de weg van de 
Torah, in. Het is een teruggaan naar de weg van leven en (geestelijke) gezondheid (zie Rosenzweig 1978,101).

Ommekeer, "tesjoeva", wordt in het Achttiengebed nog met twee andere kernwoorden verbonden. Het wordt namelijk voorafgegaan door een bede om inzicht en begrip, een bede om kennis. "Het gaat dus om weet te hebben van de Torah, van de "richtlijn ten leven" zoals J. Soetendorp 'Tora' placht te vertalen" (Elke Morgen Nieuw 1978,77). Voorts wordt 'tesjoeva' gevolgd door "het verlangen naar genezing in de zin van vergeving" (id.,189-190;zie ook Bab. Talm. Megillah $17 \mathrm{~b}$ ).

De eerste stap voor "tesjoeva" moet die mens zetten die het aangaat, de mens van wie een antwoord gevraagd wordt, maar volledige ommekeer zonder hulp, zonder een tegen-antwoord is niet mogelijk. "zonder Gods hulp is volledige omkeer onmogelijk. Maar verondersteld is, dat de mens zelf de eerste beweging makt" (Elke Morgen Nieuw 1978,192). Als de mens deze stap gezet heeft en de ander antwoord gegeven heeft, mag hij op zijn beurt steun, antwoord verwachten. "If one comes to cleanse himself, he is helped" (Bab.Talm., Shabbath 104a).

De beweging van de ommekeer bestaat uit drie stadia. Aan de hand van de betreffende 'beracha" (bede, lofprijzing) in het Achttiengebed kunnen we dit goed nagaan Deze vijfde "beracha" luidt: "Doe ons omkeren, Onze Vader, tot je Tora en breng ons nader, onze Koning, tot je dienst en doe ons terugkomen in volledige omkeer tot voor je aangezicht. Gezegend ben je, Heer, die de omkeer wil" (Elke Morgen Nieuw 1978,189 ). De drie stadia in het proces van 'tesjoeva' zijn: "Ten eerste; als de mens de weg van de overtreding volgt, dan is het eerste wat hij moet doen: zich omdraaien en de andere kant uitgaan. Daarom begint onze beracha met 'doe ons omkeren'. Ten tweede: Maar tesjoeva is niet alleen het zich afwenden van de verkeerde weg; het is ook het zich toewen- 
den naar de goede weg; het is niet alleen het zich verwijderen van de overtreding, het is ook naderen tot God. Daarom luidt de tweede bede 'breng ons nader'. Ten derde: als de mens zich zo volkomen van de overtreding heeft losgemakt, dat hij zelfs als hij weer in de gelegenheid komt, de overtreding niet herhaalt, dan is de omkeer volledig geworden en stat hij tegenover God. Daarom is de derde bede: "Doe ons terugkomen in volledige omkeer" (id.,193). Ook hier blijkt dat "tesjoe$\mathrm{va}$ ' niet alleen 'ommekeer' betekent, maar ook 'antwoord'. Ommekeer als zodanig is onvoldoende. Het gaat ook om het juiste antwoord en om de bestendiging hiervan zoals in het woord "verantwoordelijkheid" naar voren komt. op Grote Verzoendag. "Jom Kippoer", en de negen voorafgaande dagen worden de mensen speciaal tot het doen van "tesjoeva' opgeroepen. Deze dagen, ook wel de 'Tien Dagen van Ommekeer' genoemd zijn echter niet speciaal bestemd om alleen dan 'tesjoeva' te doen. Zij zijn niet de enige dagen voor "tesjoeva". Wel herinneren zij aan het belang ervan (Mishnah, Yoma VIII,9). "Tesjoeva" is iets dat elke dag, elk moment en in elke situatie mogelijk is (zie Schechter 1909,1975, $342-343$; Rosenzweig $\left.1921,1976^{4}, 363-364\right)$.

Ommekeer is iets zeer ingrijpends. Het is "de aboolute verandering van leven, van levensvisie, die plaats vindt" (Safrai 1982,13). De schrijver verwijst naar het verhaal van de profeet Jona. Toen Jona, na eerst Gods roep "Adam, war ben je?" niet beantwoord te hebben, toch naar Minivé ging, luisterden de mensen van de stad en deden 'tesjoeva'. Daarop werd Ninivé tot teleurstelling van Jona niet verwoest. Jona begreep echter niet dat het ondersteboven keren van Ninivé niet verwoesting betekende, maar 'tesjoeva'. De stad is 'omgekeerd'। De mensen hebben hun leven veranderd en leven nu naar de Torah (Safrai $1982,13)$. 
Verantwoordelijkheid is ook een belangrijk gegeven in het denken van Emmanuel Levinas. Een van de vertrekpunten in de filosofle van Levinas is het zesde van de Tien woorden (Geboden). Dit wordt meestal vertaald als 'Gij zult niet doden', maar ook wel door 'Gij zult niet moorden". Dit vertrekpunt van Levinas" denken is mede ingegeven door zijn persoonlijke ervaringen in de tweede wereldoorlog, toen hij in een Duits krijgsgevangenkamp verbleef. Maar het thema is van een verdergaande strekking dan dat het alleen door de autobiografische achtergronden van Levinas ingegeven zou of hiertoe terug te brengen zou zijn.

De uitwerking die Levinas aan het thema "Gij zult niet moorden' geeft, is gebaseerd op het omgekeerde van deze levensichtlijn. In de filosofie van Levinas is richtingbepalend: "Gij zult de ander het leven mogelijk maken". De filosofie van Levinas is de 'filosofie van de Ander'. Het westerse denken is veel meer 'filosofie van het Zelfde". Het denkt autonoom. Het denkt vanuit een eigen zelfbewustzijn en in termen van zelfverwerkelijking. Levinas sluit met zijn filosofie, dat het de Ander is die mij met zijn gelaat en stem overvalt, aanroept en ter verantwoording roept, aan bij het gedachtengoed van de joodse traditie (Bouckaert 1976,83; De Boer 1976,36$37,121-136)$. In zijn verwoording is Levinas echter geen rabbijn, maar (westers) filosoof. "De Andere is bij Levinas - in tegenstelling tot nagenoeg alle sociale filosofen - de totaal Andere en hij verontrust mij juist door zijn vreemdheid. De andersheid vooral van de in nood verkerende Andere - de vreemdeling, de weduwe, de wees - verstoort mijn egolstisch genot" (strasser 1981, 106). Het is de konfrontatie met het Gelaat van de ander, die het eigen vrije bewustzijn uit het zadel werpt. Het is het gelaat dat ons toeroept: 'Gij zult niet doden". "Het weerloze gelaat is een absolute weerstand tegen de hartstocht zich- 
zelf te zijn" (De Boer 1976,130). Een andere auteur zegt: "Negatief verschijnt het Gelat als inbreuk op en overschrijding van het narcistisch autonomiestreven van het ik (...). (Positief:) De Ander verschijnt tegenover het narcistisch-totaliserend ik als een gegeven dat door het ik niet gereduceerd kan worden tot de eigen totaliteit. Het ik dat in zelfzekerheid de wereld naar zich toehaalt, wordt als het ware opgeschrikt door de verschijning van de Ander" (Burggraeve 1981,55).

Burggraeve werkt het voorgaande verder uit en ik volg zijn uitwerking. De beweging die plaatsvinat is, dat het Gelaat zich tot mij wendt en het doet dit in zijn 'naaktheid" en niet vanuit een vooraf door mij bepaald kader of systeem. Daarom ook is de Ander de totaal Andere, "absolute alteriteit'. De situatie van de mens heeft een transcendent karakter. De naaktheid van het Gelat komt konkreet tot uiting in de blik, de ogen van de Ander. "Het meest eigene van het Gelaat is echter dat het spreekt. of liever, dat het mij aanspreekt" (Burggraeve $1981,57-58$ ).

De konfrontatie met het Gelaat van de Ander betekent, dat vanuit een volstrekt heteronome positie een (ethisch) appel op mij gedaan wordt. De ander openbaart zich aan mij. "Ik ben niet de ontwerpende, max de ontvangende, de luisterende, de ge-hoorzamel" (id.,59). "Ongevraagd word ik door de verschijning van de Ander verantwoordelijk gesteld. Deze verantwoordelijkheid gebeurt aan mij, vóór ik in stat ben ertoe te beslissen" (id, 66). Met andere woorden: aan mijn verantwoordelijkheid ligt geen menselijk-autonome "wilsact of intentie" ten grondslag, maar zij is een verantwoordelijkheid "die ouder is dan ik zelf" (Strasser 1981,107). "Het is een uitverkiezing tot verantwoordelijkheid die $\overline{\text { aan }}$ elk kiezen mijnerzijds voorafgaat" (De Boer $1976,132)$. 
De verantwoordelijkheid, die door het Gelaat van de Ander gewekt wordt, is niet autonoom maar heteronoom. In een interview - getiteld: 'Wat men van zichzelf eist, elst men van een heilige" - antwoordt Levinas op een vraag over de idee van de autonomie van het ik: "Heel zeker is de autonomie geen hoogste warde voor mij. Dat is een bijbelse gedachte: onwaardig is het om slaaf of knecht te zijn, mar beter dan de autonomie is het om in dienst van God de mens te dienen" (Levinas, bij Goud 1983, 85).

Nast leven zijn ook genezen en gezondheid geen doeleinden die op zichzelf staan. "The essence of "Iife' (...), lies in doing good deeds and cleaving to Him", zegt de bekende kommentator Abravanel uit de vijftiende eeuw (Abravanel, bij Leibowitz, 5740-1980,315). Dit dienen is geen slavernij, maar een gezonde, vrije, levenswijze. "Deze dienstbarheid is zelfs vrijheid, namelijk uitverkiezing", stelt Levinas (Levinas, bij Goud 1983,85). De mens moet vrij en bevrijd zijn, uitverkoren zijn om te kunnen dienen. In het op de juiste wijze in de wereld werkzaam zijn, namelijk in dienst van God, is hij uitverkoren en een vrij en gaaf mens.

Levinas stelt in plaats van de autonomie de uitverkiezing die in de onoverdraagbare verantwoordelijkheid gelegen is. "Voor de door Nietzsche geInspireerde moderne mens staat het dienen van God gelijk aan slavernij. Naar mijn mening echter is God te omschrijven door het feit dat dienen geen slavernij is. Dat is zelfs één van de manieren waarop God konkreet wordt. Sartre meende dat de mens gedoemd is om vrij te zijn, ik daarentegen ben van mening dat de mens bevrijd is om te dienen. Dat correspondeert met wat de Bijbel zegt: "Ik heb U uit het land Egypte doen uitgaan, opdat $U$ mij zoudt dienen'" (Levinas, bij Goud 1983,85). het is deze verantwoordelijkheid waruit het: 'Gij zult niet moorden' voortspruit. 
Deze verantwoordelijkheid heeft echter nog verdergaande konsekwenties. Zij is, ik herhaal, onoverdraagbaar. Strasser: "zij is de werantwoordelijkheid van mij en van niemand anders; ik kan ze niet overdragen, niet delegeren; an haar dank ik mijn identiteit" (Strasser 1981,107$)$. Met dit laatste verwijzen strasser en Levinas naar het antropologisch relevante gegeven, dat mijn mens zijn gerealiseerd wordt doordat de ander zich aan mij openbaart. Vergelijk Bubers: 'Ich werde am Du'. Ik kom over dit punt verderop nog te spreken. Hier is van belang dat ik en niemand anders aangesproken en verantwoordelijk gesteld ben en dat ik mij van mijn eigen menselijkheid vervreemd als ik hier niet op inga. (vgl.De Boer 1976,71-72). Een passieve houling van 'Gij zult niet moorden' is niet voldoende. Het appèl dat de ander op mij doet betekent, dat ik persoonlijk verantwoordelijk word gesteld de ander het leven mogelijk te maken; met andere woorden ik heb voor de ander in te staan, zijn leven te bevestigen. Als ik deze aktieve opstelling ontvlucht en mij afzijaig. mij neutraal houd, negeer ik toch (het appèl van) de ander die niet alleen vraagt 'Gij zult mij niet doden', maar ook de bevestiging hiervan gerealiseerd wil zien in de zin van: "makk mij het leven mogelijk'. Ik ben er ook verantwoordelijk voor, dat er niet 'gemoord' wordt. Het passief blijven bij moord en bij elke andere vorm van geweld makt mij al tot medeplichtige. De mens is geen onschulaige toeschouwer in een kosmisch drama (Heschel 1959. $1975^{7}, 160$ ).

Eén aantekening nog met betrekking tot het werk van Levinas. De zedelijke verhouding die ik tot mijn naste heb, merkt strasser op. berust niet op reciprociteit. "De vraag of de Andere" mijn gevoelens beantwoordt, of hij zich van zijn kant als broeder gedraagt, of hij mij bemint, wordt in het geheel niet gesteld. Wanneer de Ander koud is, liefdeloos, wanneer hij zich misdraagt, dan is mijn ver- 
antwoordelijkheid alleen mar groter. Want Ik ben voor de vrede met hem verantwoordelijk, de Ander niet" (Strasser 1981,107). Het is deze persoonlijke litverkiezing tot verantwoordelijkheid die Levinas "de moeilijke joodse vrijheid" noemt (De Boer 1976,83).

Ten tijde van zijn overlijden was Franz Rosenzweig samen met Martin Buber bezig met de "Verdeutschung der Schrift" (zie hoofdstuk 2). Rosenzweig en Buber waren op dat moment gevorderd tot hoofdstuk 53 in Deutero-Jesaja (Jesaja 40-55), tot het verhal van de knecht Gods (Buber $1979^{9}, 44$ ). In het tweede hoofdstuk liet ik impliciet al doorschemeren dat het beeld van de Godsknecht zich niet laat beperken tot de gestalte van één enkele persoon - hoe groot c.q. absoluut ook de betekenis van zo iemand in de geschiedenis van de mensheid geacht wordt te zijn. "Het is een beeld, dat in meerdere of mindere mate van helderheid dóór de tijden voortbestaat en zich van moment tot moment aan deze of gene mens actualiseert" (De Miranda 1983,250$)$.

Iemand die in vrijheid dient, is een Godsknecht. Hij is "de helper-ten-goede", iemand die gericht is op het doen van het wezenlijk goede. Hierbij gelden kriteria, die niet bij voorbaat in regel of 'wet' vast te leggen zijn, merkt De Miranda op. "Het zijn kriteria ten aanzien van het goede, warbij de mens niet in de eerste plaats zichzelf, mar keer op keer en konsekwent de ander zoekt: waarbij hij an de ander steeds opnieuw het goede signaleert en hij het goede bij de ander oproept en tot ontplooilng brengt" (De Miranda $1983,246-247$ ).

Degene die zo de ander het leven mogelijk makkt, is een Godsknecht. De Godsknecht die gericht is op het doen van het wezenlijk goede laat zich niet door wetten leiden, maar door de ander. Levinas: "Ik beschouw de wettelijkheid geenszins als essentieel. (...). Niet de wet, maar het gelaat is het essentiele moment. 
(...). Naar mijn mening (...) gat aan de joodse wettelijkheid de ethiek van de nabijheid vooraf. Het is evident dat het bezit van universele wetten de beste manier is om de naaste te beschermen. Rechtvaardigheid is noodzakelijk, maar wordt in laatste instantie gemotiveerd door het gelaat van de Ander" (Levinas, bij Goud 1983,148). "Het gelaat is het essentiële moment": zo niet overal, dan gaat in elk geval hier op dat joodse woorden woorden zijn die niet het jodendom tot objekt van studie hebben, mar dat zij menselijke woorden zijn, overal en altijd.

Al eerder kwam naar voren, dat de Torah als een blauwdruk van de werkelijkheid moet worden gezien (Bab.Talm., Pesahim 54a;Midrash Rabbah, Gen.R.I.1). Kennis van de Torah is essentieel om de opdrachten die het leven telkens weer geeft, op een ethisch verantwoorde wijze te kunnen vervulien. En met betrekking tot de verplichting tot handelen betekent kennis van de Torah dat men op de hoogte is van de 'halacha', van de weg die gegaan moet worden (zie hoofdstuk 3). Dit betekent allereerst dat men op de hoogte is van de 'mitswot' (het enkelvoud mitswa betekent 'opdracht') die in de Torah genoemd worden.

De schriftelijke Torah bevat 613 geboden - 248 positieve aanwijzingen en 365 negatieve. Deze 'aanwijzingen ten leven' worden de 'mitswot d'oraita", de mitswot van de Torah genoend (oraita is aramees voor Torah). Daarnaast zijn er de richtlijnen uit de mondelinge traditie die de rabbijnen geformuleerd hebben. zij worden de 'mitswot de-rabbanan', de richtlijnen van de rabbijnen genoemd (zie Bab. Talm., Pesahim loa). Ik merk nog op dat het aantal van 365 verboden overeenkomt met het aantal dagen van het zonnejaar. Het aantal 
positieve richtlijnen is gelijk an het aantal dagen van het jaar. De joodse jaarordening is op het manjaar gebaseerd. Het a antal van 248 positieve levensregels komt volgens de Tosefta en de Talmoed overeen met het aantal botten van het lichaam dat, naar men aannam, eveneens 248 was (Bab.Talm.,Nedarim 32b;Preuss 1911, $\left.1971^{3}, 66-74\right)$.

Een 'mitswa' wordt wel een 'goddelijke opdracht' genoemd. Hiermee wordt bedoeld dat zij gericht is op het bevorderen van het leven en dit tot in alle aspekten die aan het leven te onderscheiden zijn. Een 'mitswa' is dus geen religieuze opdracht in de zin van een rituele verplichting. Het onderscheid tussen "ritualistic' en 'ethical mitswot' is, vanuit het perspectief van de joodse traditie niet goed te maken (Jakobovits $1959,1975^{2}, 93$ ). Ook de zogenaamde rituele richtlijnen zijn bestemd voor iedereen en zij maken deel uit van de dagelijkse gang van het leven (Kadushin 1938, 98-99;id., 105).

Een zeer belangrijke 'mitswa' is 'pikoeach nefesj', het redden van het leven. Alle geboden wijken hiervoor terug, ook het gebod om de sabbat te houden (Bab.Talm., Yoma 85b;zie ook Rosner/Tendler $1980,122-132)$. Andere belangrijke 'mitswot' zijn de regels van de rouwtijd. Iemand wiens naste gestorven is, is zelf vrij van alle positieve mitswot. De rouwregels zijn heel nauwkeurig vastgelegd. zijzijn erop gericht de nabestaanden te laten stilstaan bij hun verlies en ook hen weer te laten terugkeren naar het leven. Een geritualiseerd en geordend rouwproces houdt verder in, dat het gebeuren zich niet in afzondering voltrekt, maar in de gemeenschap (zie zuidema 1983,73-80; Enc.Jud. ,Vol.12,485-493; in Poorthuis $1982,35-40)$. Het is een heel gezonde zaak dat het rouwproces sterk geritualiseerd is. Het verwerkingsproces kan zo het beste tot zijn recht komen.

Sommige auteurs maken nog een onderscheid tussen de 'mitswot' (tussen de als zodanig ge- 
autoriseerde geboden) en 'goede daden', de "gemilloet chassadiem', die van iedereen verwacht worden, zoals het doen van gerechtigheid (= 'tsedaka'). "Man's entire function on earth, according tot the Rabbis, is to do Good Deeds and to engage in the study of Torah and to avoid transgression" (Kadushin 1938,113). Het doen van 'goede daden' kan men ook zien als het praktiseren van de 'mitswot'. Het is het resultaat $c . q$. de konsekwentie van het leren kennen van de Torah (zie id.,114).

"Tsedaka", gerechtigheid of rechtvaardigheid heeft niet alleen betekenis op sociale gerechtigheid in de zin van lonen, arbeidsvoorwarden, het recht op een bestaansminimum, maar het kan ook inhouden, dat men tijd voor iemand heeft. Het is ook de hulp die men geeft en het vriendelijke woord of de glimlach. Het beste dat men kan geven, zegt Landau, is Torah-kennis. "Als je hem Tora leert en hem helpt weer op het goede pad te komen, heb je hem tsedaka bewezen, de hoogste vorm van een goede daad" (Landau 1983-1984,9).

Kadushin noemt naast de 'mitswot' en de 'gemillot chassidem' nog een derde konsept dat met het menselijk handelen te maken heeft, namelijk 'derech erets". De letterlijke vertaling van 'derech erets' is: "de weg van het land' of 'de weg van de aarde'; ook 'de weg van de wereld'. Deze heeft betrekking op de ethische richtijjnen en op het juist handelen van de mensen onderling (Kadushin 1938,70-72). ook de strikt ethische richtlijnen vinden hun basis in de Torah: "The Torah taught derek erez" (Kadushin 1963,42). Het hebben van zuivere motieven, een juiste houding en een goed gedrag hoort tot de 'derek erets' (Kadushin 1938,121-122). Evenals alle andere warde-konsepten is het konsept van de 'derek erets' voortdurend in ontwikkeling (Kadushin $1963,51)$.

ook de joodse medische ethiek is nog voortdurend in beweging. Eeuwenlang hebben rabbij- 
nen en artsen in goed overleg kunnen samenwerken. Niet weinig joodse artsen ook hadden Torah en Talmoed bestudeerd en lieten $\mathrm{zich}$ in hun leven en werk door de beginselen ervan leiden. Maar vooral in deze eeuw en zeker in de laatste decennia is de medisch-technische vooruitgang dermate groot geweest, dat er een heel nieuwe situatie ontstaan is. De medischtechnische geneeskunde is overheersend geworden (zie hoofdstuk 1). "The current tendency in medicine to use modern techniques of growing complexity, and to socialize medical practice, replacing the personal relationship between doctor and patient based on the respect of medical ethics, are becomjing rapidly prevalent" (Jakobovits 1959,1975 ${ }^{2}$,XIX). In onze technische tijd wordt de mens als een 'homo mechanicus' gezien. Dit vraagt om bezinning op de aard van het menselijk leven.

Jakobovits noemt in een andere publikatie geneeskunde en ethiek twee van de gewichtigste bijdragen die het jodendom an de mensheid geschonken heeft. (zie hoofdstuk 4) De basis van de preventieve geneeskunde en de openbare gezondheidkunde zijn in de Torah te vinden en veel 'mitswot' hebben hierop betrekking. Ook voor wat we tegenwoordig medische ethiek noemen legt de bijbel de grondslagen: "the sanctity and dignity of human life, the duty to preserve health, an uncompromising opposition to superstition and irrational cures, including faith-healing, a rigid code of sexual morality, and many basic definitions on moral imperatives in medical practice, including the rights of the dead" (Jakobovits 1977,332 ).

In het jodendom wordt momenteel hard gewerkt aan het (opnieuw) leggen van verbindingen tussen de rabbijns-joodse traditie en de medisch-technische, vaak zeer geavanceerde geneeskunde. Dit gebeurt niet alleen in israël, mar ook in Engeland (Jakobovits 1955. $1959^{2}$ ) en in de Verenigde Staten (Bleich 1981; Rosner/Tendler 1980;Abraham 1977,1980; Feldman 
$\left.1974,1978^{3}\right)$. De situatie waarin onze gezondheidszorg verkeert, zegt Jakobovits, "demands the restoration of confidence between rabbis and physicians, so that by joint consultations, built on mutual trust and goodwil1, a formula can be devised to ensure health for the living, respect for the dead, and compassionate sympathy for the bereaved" (Jakobovits $1977,335)$.

Voor een overzicht van de belangrijkste joodse medisch-ethische regels verwijs ik naar de hiervoor genoemde auteurs. Voor richtlijnen in konkrete situaties, zoals ten aanzien van abortus en euthanasie verwijs ik eveneens naar hen.

De plicht tot genezen leidt de joodse traditie uit verschiliende teksten af. Ik noem de belangrijkste. De eerste bron is: "Und lasse hellen ihn, aushellen" (Namen 21,19;Ex.21:19). Deze tekst betekent niet alleen dat er kompensatie gegeven moet worden voor enig aangedaan onrecht, "but is also interpreted as authorizing healing through the medical arts" (Golding 1983,272). Golding steunt hierbij, zonder dat hij dit overigens vermeldt, op de volgende Misjna-regel: "If a man wounded his fellow he thereby becomes liable on five counts: for injury, for pain, for healing, for loss of time, and for indignity inflicted" (Mishnah, Baba Kamma VIII, 1 ).

De rabbijnen zetten hun discussie voort in de Talmoed. De vrij uitvoerige diskussie eindigt dan met de woorden: "This was necessary for the lesson enunciated by the school of R.Ishmael, as taught: "And to heal he shall heal" (Ex.21:19) (are the source) whence it can be derived that authorisation was granted (by God) to the medical man to heal" (Bab.Talm., Baba Kamma 85a).

Een tweede bron waruit de verplichting tot genezen afgeleid wordt, luidt: "Steh nicht still bel dem Blut delnes Genossen" (Er Rief 19,16:Lev.19:16). Juist de negatieve formu- 
lering geeft aan deze richtlijn een buitengewoon verplichtend karakter. Jozef Caro, de auteur van de 'Sjoelchan Aroech' heeft opgemerkt dat, indien de arts niet zou helpen, dit beschouwd wordt als het vergieten van bloed van de naaste (Bleich 1981,4$)$. Ook naar aanleiding van deze tekst bestaat een 'misjna' (Mishnah, Sanhedrin VIII,7) en een 'gemara' (in de Talmoed opgenomen kommentaar op de misjna) en wel in het traktaat Sanhedrin (Bab.Talm., Sanhedrin 73a).

Een derde bron is de tekst: "dann gibs ihm zurick" (Reden 22,2; Deut.22:2). De Talmoed leidt hieruit de verplichting af dat men iemand zijn leven (gezondheid) weer moet teruggeven - "implying him himself, i.e., his person". Is dit niet meer mogelijk, met andere woorden als men iemand dood aantreft, dan geeft de Talmoed ook richtlijnen hoe dan te handelen (Bab.Talm.,Baba Kamma 81b). Mozes Maimonides (zie hoofdstuk 4) sluit bij Deuteronomium 22:2 aan, in zijn Misjna-kommentaar op het traktaat Nedarim $(I V, 4)$. Hij zegt dan: "It is obligation from the Torah for the physician to heal the sick and this is included in the explanation of the scriptural phase 'and thou shalt restore it to him', meaning to heal his body" (Maimonides, bij Rosner 1983,226 ).

De 'mitswa" tot helpen heeft konsekwenties voor de arts-patiëntrelatie en voor de ethiek van de arts. Het juiste gedrag van de arts steunt op drie noodzakelijke bestanddelen, zegt Gordon: "respect for the person, compassion, and knowledge of modern sciences" (Gordon 1983,245-250). De arts behoort het respekt voor de patiênt als een integraal deel van zijn professioneel handelen te zien. "This respect should be that with which he would want to be treated if he himself, or someone in his family, or a close friend were a patient" (id.,245). Gordon sluit hiermee aan, zonder dit overigens expliciet te vermelden, 
bij de uitleg die in de joodse traditie gegeven wordt van de tekst: "halte lieb deinen Genossen, dir gleich" (Er Rief 19,18; Lev.19: 18).

Deze uitleg bevat twee aspekten. Het ene aspekt heeft betrekking op het gegeven, dat de ander lemand is als jij - lemand die aan jou gelijk is, geschapen naar Gods beeld, naqu Zijn gelijkenis (zie Rosenzweig 1921,1976", 267). Het tweede aspekt betreft de uitleg dat je met de ander behoort on te gaan alsof jij op zijn plaats zou zitten. De ander is even menselijk als jij. Ook hij heeft tekortkomingen, kwalen en zwakheden of hij is tekort gedaan en kan in nood verkeren. Een proseliet vroeg aan Hillel hem in enkele woorden (letterlijk: in de tijd dat hij op één been kon staan'), de hele Torah te leren. Hillel zei daarop, zo zegt de Talmoed - en dit wordt wel 'de Gouden Regel' genoemd - : "What is hateful to you, do not to your neighbour: that is the whole Torah, while the rest is the commentary thereof; go and learn it" (Bab.Talm. Shabbath 31a;vgl.Lev.19:18). En leren betekent in de joodse traditie ook altijd toepassen, ernaar handelen.

Een tweede aspekt van juist ethisch gedrag in de arts-patient relatie is: "compassion for the patient and family" (Gordon 1983,247;vlg. Heschel $\left.1959,1975^{5}, 28\right)$. Terecht noemt Gordon hier, behalve de patiënt, ook degenen die in de nabijheld van de patiënt verkeren. 'Compassion" is een verwijzing naar het Hebreeuwse 'chèsed'. "Het woord betekent zoliets als 'verbondenheid" of "trouw" ". (Van Uden 1981,104). 'Compassion" sluit veraer aan bij het Hebreeuwse woord 'emet' dat 'trouw' en 'waarheid" betekent, en het hiervan afgeleide woord 'emuna', "vertrouwen'. Gordon wijst op de verbinding 'hessed ve-emet', 'betrokkenheid en trouw" (Gordon 1983,247), een verbinding die in Tenach vaker voorkomt (bijv: Gen.24:49; Gen.47:29; Jozua 2:14).

Het woord 'chèsed' staat voor Gods betrokken- 
heid bij de mens en bij de wereld (id.,104). Het woord 'chèsed' wordt nader gekonkretiseerd in het woord "chassidiem" (= degenen die trouw zijn, de vromen), dat we hiervoor in verbinding met het woord "gemillot" als "goede daden' hebben leren kennen. "Gemillot Chassidiem', goede daden, zijn dus daden van verbondenheid (Van Uden 1981,106-107). De betrokkenheid op de ander, verbondenheid, is een belangrijk basiskonsept in de joodse traditie. "Chèsed duidt op een relatie en niet op identificatie" (id.,109). "Chesed is dat het je pijn doet dat een ander pijn heeft" (id.,109). Van Uden spreekt van "een relatie tussen de ene mens en de ander" - en de beroepsmatige relatie is hier een bijzondere vorm van -, waarbij chèsed vooral betrekking heeft op "de persoonlijke betrokkenheid van de hulpverlener bij de cliënt" (id.,109). Het aspekt 'trouw' is hier altijd bij inbegrepen: "het is niet beslissend of we het altijd halen, mar of we het al dan niet opgeven" (id.,110). Gordon verwijst bij 'compassion' nog naar het hiervoor al genoemde woord 'tsedeka', dat zoveel betekent als gerechtigheid. Ook dit is een aspekt dat in de arts-patiëntrelatie mede aan de orde is (Gordon 1983, 248).

De opdracht tot het doen van "mitswot" brengt de joodse traditie tot uitdrukking in een van haar belangrijkste konsepten, namelijk 'kiddoesj ha-sjem', het heiligen van de naam. De meest direkte betekenis hiervan is, dat afgezien wordt van afgodendienst (Kadushin 1963, 231). 'Kiddoesj ha-sjem' kan in uiterste zin martelaarschap betekenen. Het jodendom denkt overigens niet zozeer aan de rol van de held of aan 'uitzonderlijke indiviauen'. "Iedereen is in staat zijn leven te heiligen" (Abram 1980,127). De Torah-tekst die an deze levensheiliging ter grondslag ligt, is onder andere deze:

"Ihr sollt heilig werden,

denn heilig bin ICH euer Gott" 
(Er Rief 19,$2 ;$ Lev. 19:2).

Verder ils de volgende tekst belangrijk:

"Wahret meine Gebote,

tut sie.

ICH bins.

Preisgebet nicht den Namen meiner Heiligung, gehelilgt will ich werden

inmitten der solhne Jissraels.

ICH bins, dex euch heiligt:

der euch fuhrt aus dem Land Aegypten,

euch Gott zu sein,

ICH bins"

(Er Rief 22,31-33; Lev.22:31-33).

'Kiddoesj ha-sjem' wordt ook betrokken op ethisch (halachisch) juist gedrag. Het heeft betrekking op de verantwoordelijkheid van de mens om Gods Naam in de wereld hoog te houden (Enc.Jud., Vol.10,978-982). "Ihr sollt heilig werden, denn heilig bin ICH euer Gott" (Er Rief 19,2;Lev.19:2), staat, ik herhaal het, in de Torah. Vervolgens volgt een groot aantal richtlijnen hoe deze levensheiliging in de praktijk gestalte te geven.

De dienst van God houdt in dat men meewerkt aan het tot stand brengen van een rechtvaardige wereld, een wereld warin aan de ander recht gedaan wordt en de ander tot zijn recht kan komen. 'Kiddoesj ha-sjem' is het heiligen van het leven van alledag, het is een streven naar een op elk moment 'halachisch' juist handelen. Abram geeft aan dat deze levensheiliging geen vanzelfsprekende, moeiteloos te verwerven vaardigheid is, mar lets dat geleerd moet worden en ook kán worden (Abram 1980,127128). Het fodendom beoogt geen training in volmaaktheid, maar een training in rechtvaaralg handelen te geven. 'Kiddoesj ha-sjem" houdt in dat het leven bevestigd wordt. 'Kiddoesj ha-sjem' is levensheiliging. 
Genezen, helen, verlossen.

In een artikel 'Huisartsgeneeskundig handelen' herinnert De Geus eraan, dat huisartsen vroeger wel als toevoeging achter hun naam zetten: "Med. drs., genees-, heel- en verloskundige". "In oorsprong", zegt hij, "verwijst deze aanduiding naar de basisvakken interne, chirurgie en verloskunde, mar ze roept associaties op die verder gaan. Bij genezen, helen en verlossen staan ons voor ogen mensen, die weer gezond worden, die heel groeien, bevrijd en ontbonden zulien zijn" (De Geus 1983, II, 1-7); vgl.Van Es 1980,73 ). De Geus geeft hiermee aan de woorden "genezen, helen, verlossen" niet alleen een medisch-geneeskundige mar ook een gezondheidkundig-antropologische oriëntatie.

Dat genezen, helen en verlossen niet alleen met ziekte verbonden worden, maar ook met het leven van de mens en met leven als mens, is van betekenis voor elke vorm van geneeskundig handelen en voor elke gezondheidkundige bemoeienis. Dat desondanks de wereld van de patiënt en de wereld van de arts twee werelden kunnen zijn, is een algemeen voorkomende ervaring in het kontakt van arts en patiënt (vgl.Schouten 1982,13-23). De arts heeft een professioneel medisch-gezondheidkundig interpretatiekader. Een patiënt verbindt ziekte altijd met zijn persoon en met zijn leven(sloop). (id.,20).

Het is deze kontekst - die verder gat dan de kontekst van ziekte alleen - war evenzeer vragen om hulp en aandacht liggen en wat de geneeskundige niet goed omheen kan. De huisarts rekent het in elk geval tot zijn taak hiervoor oor te hebben: "Het is de taak van de huisarts in principe open te staan voor vragen on hulp, (...), ongeacht de aard van de problematiek" (Basistakenpakket 1983,13). Dit openstaan vraagt van de huisarts niet alleen een bepaalde deskundigheid op genees-, heel- 
en verloskundig gebied, merkt De Geus op, maar ook een bepalde hoedanigheld in diens handelen "met betrekking tot het weer gezond worden, heel groeien, bevrijd en ontbonden zijn" van de mensen die zich tot hem wenden (De Geus 1983, II, 1-7). "Als de huisarts voorkomt in het verhal, hoop je altijd, dat hij de kennis, de moed en de toewijding heeft getoond om bij te dragen aan genezing, heling en verlossing" (id..II, 1-9).

De basis-'hoedanigheid' van waruit en waarin de huisarts deze 'bijstand' (vgl. Warmenhoven $\left.1973,1983^{2}, 62\right)$ zou kunnen geven was in de voorafgaande oriëntatie voortdurend aan de orde. Een oriêntatie voor gezond mens zijn ook. De schriftelijke en de mondelinge Torah heb ik een leerboek hiervoor genoemd (zie o.a. Ps. 19:8-11).

Door het bestaan van deze openbaring bezitten we de kennis, dat we de wereld als 'geschapen". moeten zien. Naast schepping en openbaring (lering) is er een derde bestanddeel in deze beweging, namelijk de verlossing of, zoals Rosenzweig dit uitdrukt "die ewige zukunft des Reichs" (Rosenzweig $1921,1976^{4}, 229$ ). Verlossing wil zeggen dat Gods schepping door het werk van de mens tot Rijk Gods moet worden (Buber 1968,41). Het is hierdoor dat de mens vanuit zijn geslotenheid "zum ganzen Menschen erschliesst" " zich "zum ganz erschlgssenen Menschen rundet" (Rosenzweig $1921,1976^{4}, 233$ ), niet terwille van zichzelf, "maar terwille van het werk, dat hij aan Gods wereld moet volbrengen" (Buber 1968,42).

Verlossing geeft de geschiedenis van mens en wereld een messiaans perspektief, het perspektief van hoop en voltooilng. "De geschiedenis kan worden geacht als een geweldige, doelloze kringloop - wat geweest is dat zal er zijn - maar ook als een weg naar een doel. Aan dat doel kunnen verschillende namen worden gegeven: het rijk van de vrijheid, Königtum Gottes (Buber), de eeuwige vrede. De eerste 
opvatting van de geschiedenis, waarin eigenlijk van geschiedenis in de echte zin van het woord geen sprake is, vinden wij in het oosten; De tweede is ontstaan in Israell en heeft zich voortgezet in het christendom en in de westerse kultuur. Het grote verhaal in de joodse bijbel is het verhaal van de exodus uit het land van de onderdrukking naar het land "dat ik U zal geven" en er is een weg door de woestijn" (Sperna Weiland 1978,48). De messiaanse verwachting die het jodendom als het begin van de uiteindelijke verlossing voortdurend overeind houdt, betekent: "geloof in de geschiedenis en haar betekenis" (Werblowsky, bij Aschkenasy en Van Uden 1981,116).

Verlossing, 'geoela' in het Hebreeuws, is in de joodse traditie: "in de allereerste plats verlossing uit onderdrukking en slavernij. Het verlossingsgebeuren bij uitstek is dan ook de Uittocht uit Egypte" (Aschkenasy en Van Uden 1981,119). Het zijn de ballingschapservaring en het verlangen naar verlossing die diep verankerd liggen in de joodse mensbeleving. Het zijn deze ervaringen die voor de jood de wereld om hem heen en zijn bestaan in een heel bijzonder perspektief plaatsen (vgl.zwi Marx $1983,8)$.

'Geoela' duidt niet alleen op bevrijding uit slavernij, op bevrijding uit machtsverhoudingen, maar ook op verlossing uit de dagelijkse nood en beklemming, uit "de benauwenissen die elke dag weer over ons komen" (Rashi, geciteerd in 'Elke Morgen Nieuw' 1978,210). "Verlossing omvat heel de mens, geestelijk en lichamelijk, de mens in zijn politieke en in zijn sociale situatie" (Elke Morgen Nieuw 1978, 210). Het "hele skala van mensiljke zorgen en noden" dient in het perspektief van 'geoela' te staan. "Het gaat hier over verlossing in vele facetten: national en individueel, geestelijk en materieel" (id., 210). Verlossing is een gebeuren nu, mar dit gebeuren is ook anticipatie op de toekomst, op de anwezigheid van een geheel andere situ- 
atie dan nu het geval if (zie Enc.Jud., Vol.14, 1 ; Rosenzweig $\left.1921,1976^{4}\right)$. Hierbij denkt de joodse traditie niet aan een hiernamals, maar: "The Kingdom of God, as Judaism sees it, as Judaism orlginally created it, is full of life, of earthiy life. It is a kingdom which is to be built here on earth, under divine guidance, by the hands of man, and realised as the result of human struggles and divine discipline, which constitute the very warp and woof of the process of human history" (Epstein $\left.1954,1980^{6}, 315\right)$.

In de 'geoela' hier en nu, de bevrijding van de dagelijkse noden klinkt de uiteindelijke verlossing mee - het is het (voortdurend) begin van de verlossing - ("Elke Morgen Nieuw" 1978,211-212). In alle opzichten is het verlossingsproces van mens en wereld een aardse en geen hemelse zaak. "The prophets of Israel (thus) become the originators of the conception of a divine purpose, moving toward fulfilment in the transcendental reality of an earthly future" (Epstein 1954,1980',316). Het is de opdracht van de mens "de wereld te ordenen tot Gods koninkrijk, Gods koningschap in de wereld gestalte te geven" (Aschkenasy en Van Uden 1981,117). Het Rijk Gods krijgt gestalte in de wereld, als de wereld er zorg voor draagt (Rosenzweig 1921,1976, 266).

Het Koninkrijk van God, "Malkoet Sjaddai" heeft twee kanten: het is verwachting, hoop, toekomst, maar het is ook: verantwoordelijkheid, opdracht en keuze hier en nu. "Enerzijds is het een opdracht die wij moeten uitvoeren, anderszijds een gebeuren warnaar we uitzien. $(\ldots)$. Deze twee elementen, die elkaar lijken tegen te spreken - het voortdurend in gedachten uitzien en het zich op het geschikte moment inzetten - moet men sámen in het oog houden, als men de verwachting van de bevrijding ten diepste wil doorgronden" (Koek, bij Aschkenasy en Van Uden 1981,127). "De verwachting van de verlossing, zegt Rav Koek, is enerzijds 
een steeds blijven uitkijken, ook al lijkt er niets te gebeuren, en anderzijds een daadwerkelijk meehelpen aan de voorbereiding en het ontspruiten van de verlossing" (11.,128).

Dit betekent dat de mens moet meewerken aan de verlossing. Het betekent ook dat de verlossing mede afhankelijk is van de houding van de mens. De mens die er telkens weer voor kiest 'Gods partner' te zijn, helpt mee aan de verlossing. Verlossing is, zo zegt de Talmoed uitdrukkelijk, afhankelijk van 'tesjoeva'. ommekeer, van 'gemilloet chassadiem' goede daden en van 'derek erets', de weg van het leven (Bab.Talm. Yoma 86b;id., Sanhedrin 97b). Verlossen wil zeggen scheiding aanbrengen tussen het goede en het kwade. Bij Rosenzweig hebben we gezien wat het betekent als de mens zich op het geschikte moment inzet (zie hoofdstuk 2). "Das rechte Tun" betekent dat de mens weet dat verlossend handelen met "die rechten zeit" te maken heeft. Het houdt in dat het Rijk Gods niet wordt vertraagd en niet wordt versneld, dat het op geen enkele yijze wordt afgedwongen (Rosenzweig 1921,1976 ,295-330). Bovendien betekent het dat verlosing geen eenzijdige, anonieme, aktie is, maar een gebeuren warin de ander (vgl.Levinas) de primaire plaats inneemt en als zodanig aangesproken en beantwoord wordt. Rosenzweig: "denn was ist die Erlösung sonst als dies, dass das Ich zum Er Du sagen lernt?" (id.,305;zle ook Bab.Talm. Sanhedrin 98a).

Behalve om verlossing vraagt de mens ook om heling. Verlossen heeft enigszins het aksent van een overgaan van een minder gewenste, minder volledige of minder goede situatie naar een gewenste, volledige en goede situatie. Er is sprake van een bevrijding, van vrij worden. Zolang men niet verlost is, is men gevangen in of slaaf van het een of ander. Bij het helen is meer aan de orde, dat lets dat beschadigd is, en dit wellicht oorspronkelijk niet was, weer gezond wordt (zie hoofdstuk 1;vlg.Bollnow 
$\left.1958,1967^{2}, 109-116\right)$. Niet alleen het woord verlossen, mar ook het woord helen heeft de associatie met een realiteit die transcendent van karakter is.

Helen en heel zijn taalkundig verwant met heil en heilig (zie hoofdstuk livlg.Van Es 1980, 73). Naar de woordinhoud bezien gaat het om heel, om integer (geintegreerd), om gaaf te worden en te zijn. Het Hebreeuwse woord hiervoor is "tamiem". "Geh einher vor meinem Ant1itz! sei ganz" (Im Anfang 17,1;Gen.17:1). "Ganz sollst du mit IHM deinem Gott seinl" (Reden 18,3; Deut.18:3).

Heel maken en helen betekent ook dat het geheelde weer zijn oorspronkelijke eenheid terugkrijgt of dat het één wordt. Helen is veréén-igen. En dit woord één, 'echad' in het Hebreeuws, is in de joodse traditie een belangrijk woord. Er is sprake van één God, één Israêl, één werkelijkheid, één toekomst, er is één Torah en de levensordening wordt verbonden met één dag. de sabbat. Het woord één staat bovendien in het voornaamste dagelijkse gebed, dat begint met de woorden: "Höre Jissraël, ER unser Gott, Er Einer" (Reden 6,4;Deut.6:4). En, zegt Sperna Weiland, omdat de Schepper van hemel en aarde één is, moet ook het werk van zijn handen één worden" (Sperna Weiland 1978, $58-59$ ).

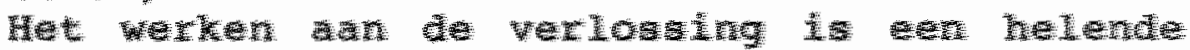

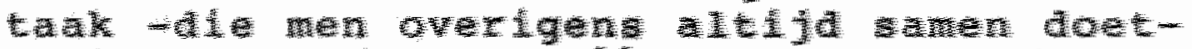

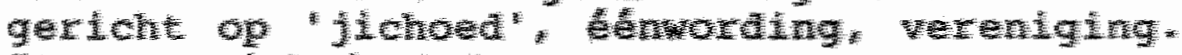

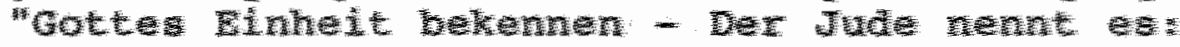

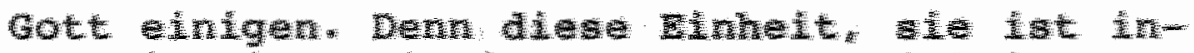

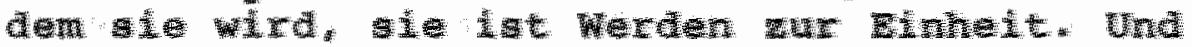

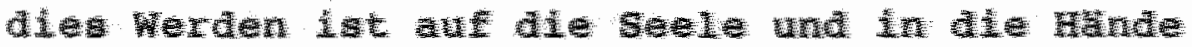

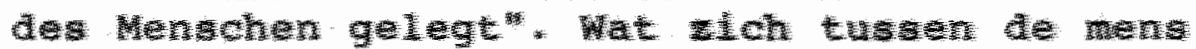

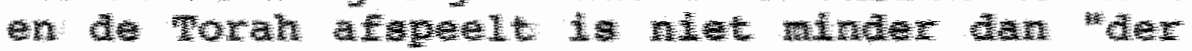
gott-, welt- und wenschumasande Morgang der

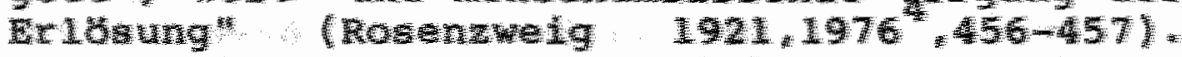

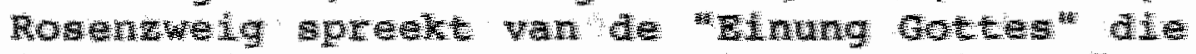

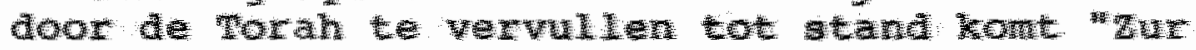

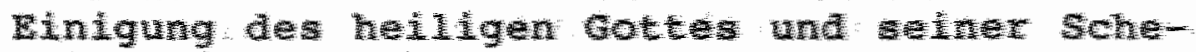

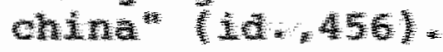


Met het woord "Sjechina" wordt Gods aanwezigheid in de wereld a angeduid. God, niet tot mens of wereld te herleiden, de transcendente God, is in de wereld aanwezig (Nave Leyinson $1982,41-46$; zie ook Kadushin 1952,1972,222261). Bij Gods aanwezigheid moet niet aan een plaats gedacht worden, mar aan "Zijn manifeste en verborgen present zijn" (Urbach 1975. $\left.1979^{2}, 40\right)$. "The concept of the shekhina does aim (...) to give expression to His presence in the world and His nearness to man, without, at the same time, destroying the sense of distance" (id.,65).

Buber noemt het woord 'jichoed' eveneens in verband met de 'Sjechina'. "Jichoed' is een belaggrijk gegeven bij Buber (Buber 1968. $\left.1978^{2}, 153-154\right)$. Sperna weiland noemt het het diepste motief van zijn leven en denken (Sperna Weiland 1978,58$)$. "Het doel van alle handelen is "jichoed", de eenmaking, de verbinding tussen God en zijn sjechina op aarde" zo verwoorat Wehr Bubers inzichten met betrekking tot wat de opdracht voor de mens inhoudt (Wehr 1971,78). "Met elk handelen kan de mens werken aan de vormgeving van de sjechina" (Buber, bij Wehr 1971,81). Schechter spreekt hier van de dienst van de jichoed en hij bedoelt hiermee "the unification of the glorious and the only Name. But the essence of Love is the true Unity, and the true Unity is what is termed Love ..." (Schechter 1909, 1975 ,75).

Jichoed gebeurt als in het gewone dagelijkse leven juist en goed gehandeld wordt. Het is geen verheven ideaal, maar het wordt in het konkrete handelen gerealiseerd. Ook de seksuele gemeenschap van man en vrouw wordt 'jichoed' genoemd. Er is een overlevering die zegt, dat als man en vrouw samen slapen, de goddelijke 'sjechina' bij hen aanwezig is. "Jichoed zegt dus voor wie de joodse taal kent veel meer dan ons woord eenheid en ook meer dan Bubers woord Einung, maar deze woorden wijzen in ieder geval in de goede richting. Jichoed is daar waar mensen een worden met 
zichzelf. Jichoed is daar waar mensen werkelijk met elkaar en voor elkaar leven en werken" (Sperna weiland 1978,59). Verwant met het woord 'jichoed' is het woord 'jachad' dat samen betekent. Buber formuleerde de betekenis van het woord 'jichoed' eens als volgt: "Der einzelne Mensch fur sich hat das Wesen des Menschen nicht in sich, weder in sich als moralischem, noch in sich als denkendem wesen. Das Wesen des Menschen ist nur in der Gemeinschaft, in der Einheit, in der Einheit des Menschen mit dem Menschen enthalten - eine Einheit, die sich aber nur auf die Realität des Unterschileds von Ich und Du stutzt" (Buber $1954,287)$.

"Mein Ich entsteht im Du".

De Torah is ook een leerboek en voor wie de Torah bestudeert blijken de woorden van de Torah levende woorden te zijn, woorden van levende mensen, woorden die op de werkelijkheid van het leven betrekking hebben, woorden die de mensen aanspreken. De Torah is een wijze van weten die handelingsbetrokken is. Dit handelen is niet mechanisch-procesmatig van aard, maar persoonlijk, en dit persoonlijke vindt in het levende woord zijn uitdrukking.

kunnen spreken, het bezit van het woord is geen 'natuurlijke' zaak. Het spreken en de taal horen niet tot de orde van de dingen, tot de orde van de wereld, van de natuur, van de kosmos. Het gebruik van het woord moet de mens aanleren. Dit kan hij alleen, zegt Ebner, als van te voren het woord in hem gelegd wordt, als hil eerst aangesproken wordt (Ebner 1921, 20). Leven is aangesproken worden en wie dit nilet gelooft, kan het alsnog gaan horen en gaan nalezen in de Torah.

"Ich habe dich bei deinen Namen gerufen. Du bist mein" (Rosenzweig 1921,19764,204). Het is dit dialogisch fundament dat in de joodse tra- 
ditie bewaard is gebleven en volgens de traditie de basis van ons bestaan vormt. In het begin van deze eeuw is het, als een antwoord op de krisis van het westerse weten, opnieuw geformuleerd door mensen als Eugen Rosenstock, Franz Rosenzweig, Ferdinand Ebner en Martin Buber. Daardoor is het 'dialogisch principe" (Buber) ook buiten het jodendom als 'sprachdenken' (Rosenstock) bekend geworden. Ik wil dit hoofdstuk besluiten met beknopt het antropologisch gehalte van dit denken onder woorden te brengen.

Nadat Rosenstock 'op geloofsnivo' in 1916 de zogenaamde joods-christelijk briefwisseling met Rosenzweig gevoerd had (zie hoofdstuk 2), was ook hij ervan doordrongen dat de Europese opvattingen omtrent leven en geschiedenis een nieuwe oriëntatie nodig hadden. Bovendien realiseerde hij zich dat deze oriëntatie het gehele mens zijn zou moeten betreffen en niet beperkt kon blijven tot een louter religieuze levensdimensie. Als blijk van zijn nieuw verworven inzicht schreef Eugen Rosenstock een artikel, 'Angewandte seelenkunde', dat hij eind 1916 als 'Sprachbrief' naar Franz Rosenzweig stuurde.

Rosenstock bekritiseerde hierin onder andere de akademische psychologie, die als enige vaste grootheid het ik naar voren brengt. Hij zegt dan: "Das Du, das Er und Sie, das "Es' der Dinge, alles andere wird erst beachtlich dadurch, dass es von dieser ersten Person der Grammatik, von dem Ich psychisch aufgenommen wird. Das 'Nichtich' oder der Nächste, oder Gott oder der 'Gegenstand" werden vom Ich gesichtet" (Rosenstock-Huessy 1963,Bd.1,753). Rosenstock meent dat het Europese denken te zeer eenzijdig vanuit de oude Griekse denkwereld is opgebouwd. Als we goed bij ons eigen mens zijn stil staan, gaat dit echter tegen elke eigen ervaring in. "Denn alle unsere eigene Erfahrung erfährt genau das Gegentell von dieser griechischen Lehre des Primats des 
Einze1-Ichs!" (id. .754).

Aan de hand van de ouder-kind situatie laat Rosenstock dan zien wat mens zijn betekent. De mens realiseert $\mathrm{zich}$, dat de eerste ervaring de ervaring van het bestaan van iets anders dan het eigen ik is. Het kind is voor de ouders werkelijk iets anders dan hun eigen ik, "es ist zuerst ein Du" (id.,754). De konklusie van Rosenstock is dan: "Alle Selbsterkenntnis, Icherkenntnis, wird hervorgerufen durch Anruf und durch ein bestimmtes sichgetroffenflihlen, das in konkreter und dem Einzelnen widerfahrender Weise das Ich herausfordert" (id.,765). Mens te $z i j n$ houdt volgens Rosenstock in: "die Antwort auf ein Du oder die sehnsucht nach dem Du" (id..768).

In een brief van 14 oktober 1917 aan Rosenstock nam Rosenzweig de vraag naar wat het is om mens te zijn weer op, alhoewel nog niet expliciet. "Die sprache muss weder deutsch noch undeutsch sondern von Angesicht $\mathrm{zu}$ Angesicht sein", schrijft hij (Rosenzweig 1935, 252;1d.1979 Bd.1.469). Deze uitspraak gaat in een brief van 19 oktober over in een werkelijke antropologie: "Vor allem aber: das eigentliche Wunder, das meine Ich, entsteht gar nicht im Ich, sondern das Ich als die Substanz ('ante festum') ist durchaus nicht mein Ich, sondern eben Ich tiberhaupt, und durch das Er wird es zwar vervielfacht, aber nunmehr Ding unter Dingen. Sondern Mein Ich entsteht im Du" (id.,254;id.,471). Het is op orientatie van deze 'Korrelation' dat Rosenzweig van 1917 tot 1921 zijn hoofdwerk "Der Stern der Erlösung" schreef.

In de winter van 1918-1919 werkte in Oostenrijk een man, Ferdinand Ebner, in alle stilte aan een boek, dat in 1921 onder de titel 'Das Wort und die geistigen Realitäten" werd gepubliceerd. ook deze man, een niet-jood, komt tot een voor het westerse denken nieuwe standpuntbepaling, namelijk "dass das Ich im Menschen auf ein Verhaltnis zum Du, ausserhalb dessen es gar nicht existierte, angelegt ist" 
(Ebner 1921,28$)$. Zowel in de praktijk van alledag als in de wetenschap vergeet het ik "ihre eigene Voraussetzung oder will sie vergessen: das Bewusstsein von der Existenz des Du" (id.,36). Het thema blijft in het boek terugkeren: "Persönliches Sein ist, vom Standpunkte des Menschen aus und fur ihn absolut geltend, immer das Existieren des Ichs im Verhältnis zum Du" (id.,36; ook $37,43,48,89$ ). Een laatste verwijzing: "Das Ich ist etwas "Werdendes"; etwas, das im Verhältnis zum Du wird oder auch entwird, je nachdem es sich eben in diesem zum Du hin - oder von ihm wegbewegt" (id.,178).

ook voor Martin Buber is "het besef hebben van de ander" karakteristiek voor het mens zijn (Buber 1970,142). Alhoewel nog niet zozeer vanuit het primat van de ander en vanuit een vooropgesteld "Du" formulerend - en daardoor (aanvankelijk) minder duidelijk dan Ebner, Rosenstock en Rosenzweig - beschreef Buber reeds in 1913 de aard en strekking van het mens zijn als "Beziehungswesen". In dat jaar publiceerde hij een boekje met als titel 'Daniel; Gespräche von Verwirklichung', waarin hij een onderscheid maakte tussen een "oriënterende, tot objekt makende grondhouding" en een "realiserende, present stellende grondhouding" (Buber 1913;id.,1970,141).

In de toen volgende jaren kreeg Buber kontakt met Rosenstock en met Rosenzweig. Bovendien leerde hij Ebners boek kennen. Dit versterkte hem in zijn opvatting van de mens als 'Beziehungswesen'. Als dan in 1923 "Ich und Du' gepubliceerd wordt, staat hier in alle helderheid een van Bubers belangrijkste uitgangspunten geformuleerd: "Ich werde am Du; Ich werdend spreche ich Du. Alles wirkliche Leben ist Beziehung" (Buber 1923,1947,23). En - even later nog eens en naar mijn idee net even scherper: "Der Mensch wird am Du zum Ich" (id.,40).

'Als je leven zoekt': het is de ander die bepalend is voor de zijnswijze van het ik. (De 
Boer 1976,35). "Leben heisst angeredet werden" (Buber 1973, 153 ). Anders gezegd: "Du lehrst mich kennen den pfad des Lebens" (Psalm 16, 11). Enkele aantekeningen.

Franz Rosenzweig heeft erop gewezen, dat een zoeken naar het wezen van het al zinloos is, en wel om twee redenen. Dat er zoiets als één al, één totaliteit zou zijn, is een fiktie. Hij wijst dan op het bestaan van God, de wereld en de mens als niet tot elkaar te herleiden 'elementen'. De tweede reden is dat het zoeken naar het wezen de mens niet verder helpt. De vraag naar het wezen laat zich alleen mar in een wirwar van tegenstrijdigheden beantwoorden, zegt Rosenzweig, en daarmee laat zij zich eigenlijk niet beantwoorden. Maar degene die zelf levend is vraagt niet naar het wezen, die vraagt naar (het) leven (Rosenzweig $\left.1921,1976^{4}, 342\right)$.

Een joodse antropologie is niet op onderzoek naar het wezen van de mens gericht, maar op 'leven'. De mens heeft een bijzondere positie: hij leeft op een geheel eigen wijze, hij wil leven. Het is de drang naar leven, zo drukt Rosenzweig dit in "Der stern der Erlösung" uit, of beter elgenlijk, het verlangen naar leven (vgl.Burggraeve 1981), dat de mens die zich in zijn menselijk leven en in zijn leven als mens bedreigd weet, bij de arts terecht doet komen. Het zoeken naar leven raakt ook de geneeskunde, de gezondheldszorg en de gezondheldkunde. Deze existentieel-antropologische gehechtheid ligt zelfs ten grondslag aan elk genees- en gezondheldkundig handelen. De geneeskunde als toegepaste wetenschap vindt haar begin-en eindnorm niet in de techniek van de toepassing. maar in het leven van de mens. Hier ligt ook het belang van de medische halacha, die in de joodse traditie van grote 
waarde is en die een groot gezag heeft.

Eén van de vragen waarvoor de arts (en niet alleen hij) zich gesteld ziet, is of hij een ontwerp van de mens dient te maken. Als hij dit doet, zit hij met het probleem dat de mens, in dit geval patiënt genoemd, in de hulpverleningssituatie aan dit ontwerp moet beantwoorden. De arts kan in zijn mensontwerp de patiënt vooral in zijn lichamelijk funktioneren zien en dit dan nog op nader te differentiëren en nader te specificeren wijzen. De arts kan de patiënt als een psycho-somatische of als een somato-psycho-sociale eenheid zien. ook dit is dan een ontwerp waar de patiënt aan moet voldoen (zie ook hoofdstuk 5) Men kan deze kwestie ook van een heel andere kant proberen te benaderen. Hierbij gaan we er niet vanuit dat de mens aan mijn of aan ons ontwerp moet beantwoorden, maar dat het om een ontwerp gaat dat aan de mens, aan de ander beantwoordt. Het is zelfs de vraag of we wel van een ontwerp kunnen spreken. Een ontwerp is een abstrakt iets. Eerder gaat het om een beweging in het leven. Als we over de ander praten, gaat het in werkelijkheid niet om wat ik of wij vanuit een autonome opstelling denken, mar om een konkrete ander. De andere mens komt op onze weg en hij treft ons. Dit leidt van mijn kant niet tot een ontwerp of een inpassing in een ontwerp, maar tot een antwoord en tot ommekeer. De ander roept mij ter verantwoording en hij vraagt van mij mijn autonome gang af te leggen, om te keren en het tot op dat moment vreemde leven in mijn eigen leven(sontwerp) mee te nemen. Hier ligt de kern van Rosenstock-Huessy's 'Sprachdenken' en Franz Rosenzweigs 'Neues denken' en 'Neues Lernen'.

Het belangrijkste is daarom niet dat ik met spreken begin. Dit kan alleen maar monoloog zijn, het geven van informatie, zolang dit geen antwoord op een vraag is, gaat het om iets voortijdigs. De tijd en daarmee de ander, 
wordt geweld aangedaan (zie Rosenzweig, hoofdstuk 2). Ook in de hulpverlening is dit aan de orde. Het belangrijkste is ook niet dat ik mij luisterend opstel om de ander te begrijpen. ook dan blijf ik binnen mijn autonoom ontwerp steken. Wel zal dit in de hulpverlening een facet zijn (zeker in de geneeskunde) dat niet verwaarloosd mag worden. Het belangrijkste is dat ik zó luister, dat ik mij in de levende ander en in diens levenssituatie kan verplaatsen en dat ik daarin de vragen beluister die die ander mij aanbiedt en daarop antwoord, al is het mar met een wedervraag (vgl.Buber $1933,25)$. Eerst dan is er ruimte voor een echt gesprek, voor wat wij samen vinden (zie Rosenzweig 1937,387 ; Kreider 1983-1984,5-7). Ook in de hulpverlening is het van essentiëel belang de ander niet alleen in zijn ziekte of vanuit een of ander gedacht ontwerp te benaderen. mar vanuit zijn mens zijn en zijn leven. Eerst dit leidt tot een werkelijk geneeskundig ' leergesprek'.

In onze huidige situatie van onzekerheden en krises, ook in de geneeskunde, kan de medische halacha en de joodse traditie in het algemeen een bijdrage leveren aan ons eigen "leergesprek' voor een betere gezondheidszorg en een betere wereld. Het jodendom ligt aan de basis van onze kultuur en het maakt tot de dag van vandaag er een deel van uit. De basisvoorwarden uit de Torah gelden bovendien voor alle mensen. Volgens de traditie zijn joden verplicht de gehele Torah na te leven - en of $\mathrm{zij}$ dit doen behoort tot ieders persoonlijke vrijheid en verantwoordelijkheid -, terwijl iedere niet-jood als 'een zoon van Gods verbond met Noach' (Gen.9) beschouwd wordt (Enc.Jud. Vol. $12,1189)$.

De erkenning hiervan brengt, naast een zekere verbondenheid met de Torah-traditie (zie Bab. Talm., Avodah zarah 64b), ook zekere verplichtingen met zich mee. Het zijn deze verplichtingen die bekend staan onder de naam van de 
zeven Noachiedische geboden. (vlg.Cohen 1919, $\left.1978^{4}, 140-145\right)$. "Seven precepts were the sons of Noah commanded: social laws; to refrain from blasphemy; idolatry; adultery; bloodshed; robbery; and eating flesh cut from a living animal" (Bab.Talm.,Sanhedrin 56a). De zeven Noachiedische levensaanwijzingen hebben op alle mensen betrekking, zegt de Talmoed. Eerst op de Sinal ontving het volk Israël de Torah (zie id.,Sanhedrin 56.60). De Torah begint niet met Israël, maar met de mens.

Deze studie van de joodse traditie als levensoriëntatie en daarmee voor gezondheid en genezen eindigt hier. Ik beschouw de Torah als een burcht voor het leven en een leerhuis, of, zoals dit in het oude Israël het geval was, een tent (zie Scheepstra 1983,17-18;Midrash Rabbah, Gen.R.LXIII, 10), voor gezondheid en genezen, "um deines Lebens willen" (Reden 30,6; Deut. 30:6).

"Schau Zion an,

die Burg unsrer Begegnung!

deine Augen sehen Jerusalem, eine sorglose Heimat,

ein Zelt, stets unaufgepackt,

unausgezogen seine pflöcke auf Dauer,

unzerrissen all seine Seile.

Denn ist dort ein Mächtiger:

Mit uns ist ER!

(..)

Doch braucht nun kein Anwohnender zu sprechen: Ich bin krank!"

(Jeschajahu $33,20-24$; Jes . 33:20-24). 
SAMENVATTING.

In het eerste hoofdstuk van dit proefschrift wordt ter sprake gebracht, dat de woorden 'gezond' en 'gezondheid', niet alleen betrekking hebben op de lichamelijkheid van het mens. zijn, maar ook op de psychische gesteldheid en de sociale situatie van de mens. Gezond mens zijn is bovendien gebonden aan de kultuur, de geschiedenis, de traditie, waarin de mens leeft. De woorden 'gezond' en 'gezondheid' komen hiermee op existentieel-antropologisch nivo te liggen. Ze hebben betrekking op heel de mens en het menselijk leven.

De vraag naar wat het is om mens te zijn, naar wat 'leven' wil zeggen, is daarom een relevante vraag. Dok de geneeskunde - en door zijn positie aan de basis de huisarts als eerste wordt met deze vraag gekonfronteerd. Frankl konstateert dat de samenleving in een existentieel vakuim verkeert. Dit betekent dat een als zodanig te ervaren existentieel-antropologische basis voor het mens zijn en daarmee voor het gezond mens zijn ontbreekt.

Speciaal in tijden van $k r i s i s$ en snelle veranderingen is het van het grootste belang voeling te houden met de geestelijke uitgangspunten die aan onze kultuur ten grondslag liggen. Met het oog op 'leven' en op het gezond mens zijn is dit niet alleen voor de lijdende mens, 'de patient', van belang, mar ook voor artsen en andere hulpverleners.

Het weten omtrent de mens en zijn leven dat de basis vormt van onze christelijke en humanistische wereld, ligt verankerd in de Grieks-romeinse en in de joodse wereld- en levensbeschouwing. In deze studie gaat de volle aandacht uit naar het weten van de joodse traditie. Dit joodse weten geniet weinig bekendheid en de relevantie ervan voor gezond menselijk leven wordt niet gezien. Het kent, wat weinigen beseffen, kontinuiteit tot op de huidige 
dag.

Uitgangspunt is dat dit weten wordt opgevat als "het vooronderstelde" (Loen). Dit wil zeggen dat dit weten als zodanig niet ter diskussie staat, maar dat men het wel kan leren kennen, als men het eenmal als voorondersteld weten heeft aanvaard. In dit weten gaat het niet om een (menselijke) theologie, maar om een (goddelijke) antropologie (Heschel). In de joodse traditie staan de mens en het gezonde bestaan als mens centraal.

In deze studie worden twee hoofdlijnen of -vormen onderscheiden waarlangs het joodse weten verwoord is en wordt: een rabbijnse en een filosofische. De auteur kwam in eerste instantie in kontakt met het filosofisch-joodse weten, met name met het werk van Martin Buber, Franz Rosenzweig en Emmanuel Levinas. Rosenzweig bleek hierbij een centrale positie in te nemen.

Zoals in het tweede hoofdstuk wordt uitgewerkt, (her)ontdekte, mede door de persoonlijke konfrontatie met zijn eigen jood zijn, Franz Rosenzweig in het begin van deze eeuw, dat het joodse weten zijn relevantie voor onze levenswerkelijkheid niet heeft verloren. In een wereld die het zicht op de joodse traditie op grote schaal was kwijtgeraakt look voor de joden zelf gold dit), ging Rosenzweig het als zijn taak zien, met het oog op de toekomst van de mensheid, de oude woorden van de joodse gedachtenwereld opnieuw te formuleren en het leven hieraan te "toetsen". Hij sprak van een "Neues Denken" en van een "Neues Lernen". Het gat niet om het wezen van de werkelijkheid, maar om de werking ervan, zo stelde hij. Daarbij kan men niet van één zijnde spreken, maar er zijn er drie: God, de wereld, de mens. Deze zijn ieder op een eigen manier op elkaar betrokken, stelt Rosenzweig in zijn hoofdwerk

'Der Stern der Erlösung'. Ieder hebben zij hun eigen handelingsmogelijkheid c.q. hun eigen werking. 
Kenmerkend voor de wereld is, dat zij' schepping" is. Dat de mens hiervan weet heeft, benoemt Rosenzweig met het woord "openbaring". Dat de mens als openbaringsontvanger een taak in de wereld heeft, benoemt hij als 'verlossing". Mens zijn houdt in: in betrekking staan tot de medemens, tot de wereld, tot God. De mens $\mathbb{i s}$ primair betrekkingswezen. Als zodanig is hilj 'gezond' mens.

In het derde hoofdstuk gaat alle aandacht naar het rabbijnse denken en de rabbijnse literatuur. Dit weten vormt ook de grondslag voor het filosofisch-joodse weten, mar tegelijk is het een geheel eigen genre. Als we van joodse traditie spreken, heeft dit veelal betrekking op dit rabbijnse weten.

In dit hoofdstuk wordt het eigen karakter en het ontstaan van de joodse traditie beschreven. Kenmerk bij uitstek is dat zij een traditile is van "permanent leren" (Abram). De studie van de zogenaamde schriftelijke Torah en de literatuur hier rondom heen, de zogenaamde mondelinge Torah, staat centraal en de levensvragen worden hierop betrokken en omgekeerd. Alleen al van de studie van de Torah wordt gezegd, dat zij leidt tot gezond leven.

Leren om te leven en leven om te leren, dit is wat de rabbijnen altija met de Torah gedaan hebben en nog doen. De speciale plaats hiervoor is het leerhuis en dit leerhuis is daar war men (joods) leert. Het leerhuis is een van levensbelang zijnde instelling. Franz Rosenzweig onderkende dit, toen hij in de twintiger Jaren van deze eeuw in Frankfurt am Main het Vrije Joodse Leerhuis oprichtte.

Het vierde hoofdstuk is de verwerking van een verkennend onderzoek naar de joodse traditie met betrekking tot het thema gezondheid en genezen. Enkele belangrijke karakteristieke gegevens uit leder van de drie grote perioden van onze geschiedenis - de oudheid, de midaeleeuwen, de nieuwe en moderne tijd - worden be- 
sproken.

Met betrekking tot de eerste periode komt onder andere naar voren dat gezondheld een ruime, op 'leven' gerichte, betekenis heeft. Dit blijkt uit een van de centrale gebeden van de joodse traditie, het Achttiengebed. Hieraan wordt daaarom apart aandacht besteed. Daarnaast, zo blijkt uit de literatuur, zijn er in de bijbels-talmoedische tijd allerlei voorschriften en voorzieningen geweest die gericht waren op verzorging en genezing van de gebrekkige en zieke mens. Ook bestonden allerlei voorschriften die een goede lichamelijke gezondheid moesten waarborgen. De zorg voor de gezondheid en de hygiëne was niet opgedeeld in specialismen, maar $\mathrm{zij}$ was een algemene voorziening die ingebouwd was in het leven van de gemeenschap.

Wat de tweede periode betreft, de middeleeuwen, valt op, dat er toendertijd veel joodse artsen waren die tevens talmoedgeleerden waren. Een van de bekendste is Mozes Maimonides. Diens werk krijgt expliciet aandacht.

Betreffende de derde periode worden enkele belangrijke aspekten uit de rabbijnse literatuur genoemd. Ook wordt met betrekking tot het huidige Israël een verwijzing gegeven. Tenslotte worden uit de filosofisch-joodse literatuur enkele vooral psychotherapeutische belangrijke punten ter sprake gebracht.

Franz Rosenzweig heeft aangegeven dat, nu het leren rond de Torah voor veel geassimileerde joden niet meer het middelpunt van hun leven uitmaakt, het beter is de omgekeerde weg te bewandelen. Dit houdt in dat het leven, zoals het in onze tijd vorm gekregen heeft en zoals wij dat nu ervaren, aan de Torah en de traditie moet worden gerelateerd. Vanuit de situatie waarin de auteur werkzaam is en waarin hij met huisartsen kontakt heeft, tracht hij in hoofdstuk 5 deze procedure te volgen door naast enkele konsepten uit de huisartsgeneeskunde relevante konsepten uit de joodse tradi- 
tie te leggen.

De huisartsgeneeskunde beoogt open te staan voor gezondheidsproblemen in de meest ruime zin, met andere woorden haar benadering is integraal van karakter en is gericht op de somatische en ook op de psychische en sociale aspekten van het mens zijn. zij stelt zich bovendien open voor de levensloop van de mens. De vraag die aan de orde is, houdt in dat de theoretische konsepten van de integrale geneeskunde (benadering) en van de levensloopgeneeskunde wel eens aan verdieping kunnen winnen door het joodse weten hierbij te betrekken. Deze toetsing, zo blijkt in dit hoofdstuk, leidt weliswaar tot een voortgaand inzicht in het joodse weten, mar toch ook tot de konstatering dat een synthese niet eenvoudig is.

In het laatste hoofdstuk gaat de meeste aandacht naar een aantal antropologisch relevante aspekten uit het joodse gedachtengoed. De mens is, om te beginnen, geschapen naar het beeld van God, naar zijn gelijkenis. Kenmerkend is zijn vrijheid van wil en dat hij in zijn handelen kan worden 'als' God (Fromm). De mens die 'gaaf' en gezond is, weet zijn verantwoordelijkheld in de wereld - in de konfrontatie met het gelaat van de ander (Levinas) - op zich te nemen.

ook in het medisch handelen is de verplichting tot verantwoordelijkheid en tot juist en rechtvaaxdig handelen een kernpunt. Het is de medische "halacha" die hiervoor richtiijnen geeft. In het tweede deel van dit hoofdstuk gat de schrijver hierop in.

In het derde deel komt aan de orde hoe genezen in het perspektief van het 'helen' gezien moet worden en hoe dit een verlossend karakter draagt. De kern van dit verlossend gebeuren antwoord op de titel-vraag 'als je leven zoekt' - is dat het uitsluitend om de ander (de Ander) gaat in het leven: "Du lehrst mich kennen den Pfad des Lebens" (Psalm 16,11). 
De woorden "Der Mensch wird am Du zum Ich" (Buber) en "Mein Ich entsteht im Du" (Rosenzweig) bevatten het antwoord op de antropologisch-gezondheidkundig belangrijke vraag "als je leven zoekt'. Het valt na te lezen en te horen in de Torah, de schriftelijke én de mondelinge: "Alles is in haar vervat" (Mishnah, Aboth V, 22). 
SUMMARY.

'IF YOU SEEK LIFE'.

HEALTH AND HEALING IN ANTHROPOLOGICAL PERSPECTIVE: JEWISH TRADITION AS AN

ORIENTATION FOR LIFE.

The terms 'health" and "healthy', - discussed in the first chapter of this thesis - do not only refer to the physicality of man, but also to his psychological and social condition. To be healthy is also a function of the culture, history and tradition in which man lives. Thus, the terms "health' and "healthy' are existential and anthropological in their implication; they concern the whole human being, his whole life.

Thus it is relevant, to ask what it means to be human, what 'life' means. Such questions also confront the medical profession and, in the first place, the family physician. Frankl observes that society is in an existential vacuum, meaning that it lacks a conscious existential-anthropological basic consensus concerning human existence, healthy human existence, human health.

Especially in times of crisis and rapid change it is of the utmost importance to keep in touch with the spiritual principles that underly our culture. In as much as 'life' and healthy human existence are concerned, this is not only important for the suffering human. the 'patient', but also for doctors and those others who provide help.

The teaching regarding man and his life which forms the basis of our Christian and humanistic world is rooted in Graeco-Roman and Jewish views on world and life. It is this Jewish tradition that is the specific object of the present study. This form of teaching is often overlooked, and its relevant value for truly healthy life is not recognized. It has. 
though not many are aware of it, a continuity down to the present day.

This teaching is perceived as a set of preconceived ideas, which, though in itself not open to discussion, is open to investigation, having been presupposed. What is at stake in this teaching is not (human) theology, but (divine) anthropology (Heschel). The Jewish tradition especially concerns man and his healthy existence as such.

In this thesis the author has distinguished between two main lines in the formulation of Jewish learning: the rabbinical and the philosophical. The author became acquainted in the first place with the philosophical form of Jewish learning, particularly with the work of Martin Buber, Franz Rosenzweig and Emmanuel Levinas. Rosenzweig proved to hold a central position in this context.

As can be found in chapter two, Franz Rosenzweig ( $r e)$ discovered, early this century, that Jewish teaching had not lost its relevance for the realities of our 1 ife. This was also due to a personal confrontation with his own Jewishness. In a world which had largely lost sight of the Jewish tradition, even among Jews themselves, Rosenzweig made it his aim, with a view to the future of mankind, to formulate anew the old tenets of Jewish thought and to 'test' them. He spoke of a "Neues Denken" and of a "Neues Lernen".

As he puts it, what matters more than the essence of reality, is its working. Furthermore, one cannot speak of one form of being: there are three, namely God, the world and man. Each of these, described by Rosenzweig in his main work "Der stern der Erlösung', is related to the others in a particular way. Each of these has a particular possibility of activity, a particular effect.

A characteristic of the world is, that it is 'creation'. Rosenzweig calls the fact that man is aware of this, "revelation; the fact that 
man, as receiver of revealed knowledge, has a task in the world, he calls "redemption". To be human means to stand in relation to one's fellow-man. to the world, to God. Man is primarily a relational being; it is in this capacity that he is "healthy".

The third chapter concentrates on rabbinical thought and literature. This teaching also forms part of the basis underlying Jewish philosophy, but it is at the same time an independent genre. When we speak of the Jewish tradition we often mean rabbinical teaching. In this chapter the origin and character of the Jewish tradition is described. Its foremost characteristic is that it is a tradition of 'Iifelong learning' (Abram). The study of the so-called written Torah, and of its collateral literature, the so-called oral Torah, takes a central position; questions of life are related to it, and vice versa. The study of the Torah is said to lead in itself to a healthy life.

Learning in order to live, living in order to learn, that is what the rabbis have always done, and still do, with the Torah. The assigned place for this Jewish study is the House of Learning. This House of Study is an institution of vital importance. Franz Rosenzwelg realized this when he founded, during the 1920's, the Free Jewish House of Learning at Frankfurt/Main.

Chapter four is the result of an inquiry into the Jewish tradition as related to the themes of health and healing. Certain characteristics of each of the three perlods of our history antiquity, midale ages, and the new modern period - are enumerated.

In the first of these periods it appears that "health" has a wide meaning, embracing all of life. In one of the central prayers of the Jewish tradition, the 'Shemoneh Esreh', this point is a theme; for that reason I have paid 
special attention to it. Furthermore it can be gathered from the literature, that in the biblical-talmudic era a large number of rules and provisions existed for caring for, or curing, the handicapped or the diseased. A number of precepts also existed which intended to ensure good physical health. Care for health and hygiene was not divided into specialties, but was a general provision which formed part of the daily life of the community.

In the second of these periods, the middle ages, it is striking that there were many Jewish physicians who also were Talmudic scholars. Among the best known is Moses Mallmonides, to whose work special attention is paid.

Concerning the most recent period some important aspects of rabbinical literature are indicated. Reference is also made to the case of present-aay Israel. A few important points - especially therapeutic - in philosophical Jewish literature are enumerated.

Franz Rosenzweig has indicated that, since studying the Torah is no longer the central focus of the lives of assimilated Jews, it is better to do the converse, i.e. to relate present-day life and our experience of it back to the Torah and to the tradition. The author attempts to apply this procedure starting from his own situation, which brings him in contact with family physicians. This forms the substance of chapter five, in which certain ldeas in family medicine are collated with Jewish tradition.

Family medicine aims to be open to health problems in the widest sense of the term: in other words, its approach is comprehensive and holistic. It is directed not only at the somatic, but also at psychological and social. aspects of human existence. It is also open to the patient's personal life history. This raises the question whether theoretical con- 
cepts of holistic medical care and of medical care involving patient's personal histories can profit from the insights of Jewish teaching. As this chapter makes clear, such mutuality may lead to a progressively deeper insight into Jewish learning. However, it is also concluded that a synthesis is not altogether simple.

The final chapter concentrates on a few aspects of the Jewish heritage which have anthropologically relevant implications. To begin with, man has been made in God's image, and in His likeness. He is characterized by his freedom of will and by the fact that in his actions he can become 'as" God (Fromm). The human being who is whole and healthy, knows how to shoulder his responsibility in the world, in his confrontation with an other human being (Levinas).

In medical practice too, the duty of responsibility and justness, is a central issue. It is the medical 'halacha' which provides cues in these matters. This is dealt with in the second part of the chapter.

The third part deals with the way in which a cure must be seen within the perspective of "healing", and how this can have the character of redemption. At the core of this redemption - the answer to the question: "if you seek life" - lies the fact that in all of life it is exclusively the other (the other) who matters: "You make me know the path of life" (Psalm 16,11).

The expressions "Man becomes I by you" (Buber) and "My I originates in you" (Rosenzweig) contain the answer to the anthropologicallymedically important question if you seek iffe". It can be read and heard in the Torah, both the written and the oral: "all is within it" (Mishnah, Aboth V, 22). 
ZUSAMMENFASSUNG.

"WENN DU AUF DER SUCHE NACH DEM LEBEN BIST" . GESUNDHEIT UND HEILUNG IN ANTHROPOLOGISCHER PERSPEKTIVE: JUEDISCHE TRADITION ALS LEBENSORIENTIERUNG.

Im ersten Kapitel dieser Dissertation wird ausgearbeitet, dass die wörter "gesund" und 'Gesunaheit' sich nicht nur auf aie körperlichkeit des Menschseins, sondern auch auf das psychische und soziale. Befinden des Menschen beziehen. Gesundes Menschsein ist ausserdem verknüpft mit der Kultur, der Geschichte und der Tradition in der der Mensch lebt. Die wörter "gesund' und 'Gesundheit" geraten hier mit auf eine existenziell-anthropologische Ebene. Sie beziehen sich auf das ganze Menschenleben.

Deshalb ist die Frage, was es bedeutet Mensch zu sein, was 'Leben' bedeutet, relevant. Auch die Medizin und zwar aufgrund dessen Basisposition an erster Stelle der Allgemeinarzt, wird mit dieser Frage konfrontiert. Frankl stellt fest, dass die Gesellschaft sich in einem existenziellen Vakuum befindet. Dies bedeutet, dass eine als solche empfundene existenziel1-antroplogische Basis, sowohl fur das Menschsein, wie auch fur das damit verbundene Gesundsein und die menschliche Gesundheit. fehlt.

Besonders in Zeiten der Krise und schneller Aenderungen ist es von grosster Bedeutung, den Kontakt mit den geistigen werten, die ihn unserer Kultur verwurzelt sind, aufrechtzuerhalten. Im Hinblick auf das 'Leben' und des gesunde Menschsein ist dies nicht nur fur den leidenden Menschen, den Patienten, sondern auch fur den Arzt und sonstige medizinisch Tätige, von Bedeutung.

Das Wissen im Hinblick auf den Menschen und dessen Leben, das unserer christlichen und hu- 
manistischen Welt zugrundeliegt, ist in der griechisch-römischen Kultur und in der judischen Welt- und Lebensanschauung verwurzelt. In der vorliegenden Untersuchung steht die judische Tradition (das jüische Wissen) zentral. Dieses jualsche wissen ist nicht allgemein bekannt und wird wohl deswegen nicht in seinem Wert und in seiner Relevanz für wirklich gesundes Leben anerkannt. Dieses Wissen hat sich, obwohl sich dessen nur Wenige bewusst sind, bis in unsere zeit kontinuiert. Dieses Wissen wird als etwas 'Vorausgesetztes" (Loen) aufgefasst, d.h. ein Wissen, das, einmal als etwas Axiomatisches bejaht, man sich als solches aneignen kann. Darin geht es nicht um eine (menschliche) Theologie, sondern um eine (göttliche) Anthropologie (Heschel). Die judische Tradition bezieht sich besonders auf den Menschen und auf dessen gesunde menschliche Existenz.

In dieser studie werden zwei Hauptlinien bzw. Formen untexschieden, in denen das jüdische wissen nach wie vor formuliert wird, und zwar eine rabbinische und eine philosophische Form. Die Bekanntschaft mit den philosophisch-juidischen Werken von Martin Buber, Franz Rosenzweig und Emmanuel Levinas, wobei Rosenzweigs Philosophie eine zentrale stelle einnahm, bildeten die ersten Ansätze zu dieser studie. wie im zweiten Kapitel dargelegt wird, kam Franz Rosenzweig - auch durch eine persönliche Konfrontation mit der Tatsache, dass er selber Jude war - am Anfang dieses Jahrhunderts zur (Wieder)entdeckung, dass das judische Wissen noch immer seine Relevanz fur unsere Lebenswirklichkeit besitzt. In einer welt, die ihren Kontakt mit der judischen Tradition grösstentelis verloren hatte (auch unter den Juden), fing Rosenzweig an, - hinsichtlich der zukunft der Menschheit - es als eine Aufgabe zu sehen, die alten Worte der judischen Gedankenwelt neu zu formulieren und zu beleben, und das Leben mit dieser Gedankenwelt zu konfrontieren. Er 
sprach von einem "Neuen Denken" und von einem "Neuen Lernen". Es gehe, so sagte er, nicht um das Wesen der Wirklichkeit, sondern um deren Wirkung. Dabei kơnne nicht von einem seienden gesprochen werden. Es găbe drei Arten von Seiendem, nămlich: Gott, die welt und den Menschen. Diese sind alle auf jeweils eigene Weise miteinander verbunden, wie er in seinem Hauptwerk "Der Stern der Erlösung" darlegt. Alle drei haben ihre eigene Handlungsmöglichkeit, bzw. ihre eigene wirkung.

Charakteristisch für die Welt ist, dass sie "Geschöpf' ist. Dass der Mensch dieses kennengelernt hat, nennt Rosenzweig 'Offenbarung'. Dass der Mensch als Offenbarungsempfänger eine Aufgabe in der Welt hat, nennt er 'Erlösung'. Menschsein bedeutet: Das sich Befinden in einem Verhältnis zum Mitmenschen, zur Welt und zu Gott. Der Mensch ist primär ein Beziehungswesen. Als solcher ist er ein 'gesunder' Mensch.

Im dritten Kapitel steht das rabbinische Denken und die rabbinische Literatur im Vordergrund. Dieses Wissen ist zugleicherzeit die Basis für das philosophisch-juaische Denken, ist jedoch eine selbstandige Form an $\mathbf{s i c h}$. Wenn wir von der juidischen Tradition sprechen, bezieht sich dies meistens auf dieses rabbinische Wissen.

Im obigem Kapitel wird der eigentliche Charakter der jüdischen Tradition und dessen Entstehen dargelegt. Wesentlich kennzelchnend ist hier, dass sie eine Tradition des 'lebenslangen Lernens" (Abram) ist. Das studium der sogenannten schriftlichen Torah wie auch der mündichen, später schriftlich festgelegten, Torah, steht zentral. Die Lebensfragen werden mit diesen studium in verbindung gebracht, so wie auch umgekehrt. Schon vom studium der Torah wird gesagt, dass dies zu gesundem Leben funrt.

Lernen um $z u$ leben und leben um $z u$ lernen; das ist was die Rabbiner nach wie vor mit der To- 
rah tun. Der geeignete ort hilerfür ist das Lehrhaus, und dieses Lehrhaus ist dort, wo man (judisch) lernt. Das Lehrhaus ist also eine lebensnotwendige Einrichtung. Franz Rosenzweig erkannte dies als er in den zwanziger Jahren dieses Jahrhunderts in Frankfurt am Main "das Freie Judische Lehrhaus' errichtete.

Das vierte Kapitel befasst sich mit der Verarbeitung einer Untersuchung in bezug auf das Thema Gesundheit und Gesundwerden. Einige wichtige charakteristische Aspekte aus jeder der drei grossen Perioden unserer Geschichte der Antike, dem Mittelalter, der neuen bzw. modernen zeit - werden hervorgehoben.

Hinsichtlich der ersten Periode ergibt sich unter anderem, dass Gesundheit eine weite, auf das 'Leben' gerichtete, Bedeutung hat. In einem der zentralen Gebete der judischen Tradition, dem 'Achtzehngebet', kommt dies zum Ausdruck. Deshalb wird dies auch eigens hervorgehoben. Ferner, so lehrt uns die Literatur, hat es in biblisch-talmudischer zeit allerhand vorschriften und Vorkehrungen gegeben, die auf Versorgung und Genesung der gebrechlichen und kranken Menschen ausgerichtet waren. Auch gab es allerhand Vorschriften, die eine gute körperliche Gesundheit garantieren mussten. Die Sorge fur die Gesundheit und die Hygiene war nicht in Fachgebiete aufgeteilt worden, sondern war eine allgemeine Vorkehrung, die im Leben der Gemeinschaft eingebaut war.

Was die zweite Periode, das Mittelalter, anbetrifft, so fallt auf, dass es damals viele jlidische Aerzte gab, die gleichzeitig talmudische Gelehrte waren. Einer der bekanntesten unter ihnen war Moses Maimonides, dessen Werke in dieser studie berlicksichtigt werden.

Im Hinblick auf die dritten Periode, werden, neben einigen wichtigen Aspekten der rabbinischen Literatur und einem Hinweis auf das heutige Israel, auch einige, besonders therapeutisch wichtige, punkte der philosofisch-juidschen lititeratur erwähnt. 
Franz Rosenzweig hat angedeutet, dass, wo das Lernen der Torah flir viele assimilierte Juden nicht mehr die zentrale Tatsache ihres Lebens ist, es besser wäre, den umgekehrten weg zu gehen. Dies bedeutet, dass das Leben, wie es in unserer zeit sich gestaltet hat und wie es jetzt empfunden wird, auf die Torah und die Tradition ruckbezogen werden muss. Der Autor hat, aus seiner eigenen Arbeitssituation, bei der er mit Allgemeinarzten in Verbindung steht, versucht im funften Kapitel diese Prozedur anzuwenden durch einige 'Konzepte' aus der judischen Tradition neben die der Allgemeinmedizin zu legen.

Die Allgemeinmedizin beabsichtigt, fur Gesundheitsprobleme im weitesten Sinne aufgeschlossen zu sein. d.h. ihre Betrachtung hat einen Integralcharakter und richtet sich auf die somatischen wie auch auf die psychischen und sozialen Aspekte des Menschseins. Sie berlicksichtigt ausserdem den eigenen Lebenswandel. Die hier zur Diskussion stehende Frage ob die theoretischen Konsepte der Integral-Medizin und der Lebenslauf-Medizin zu einer Vertiefung fuhren wird, wenn das judische Wissen hier miteinbezogen wird, - ein solcher Versuch ergibt sich in diesem Kapitel - fuhrt zu der Feststellung, dass eine synthese nicht einfach ist. Die Einsicht in das judische Wissen wird jedoch vertieft.

Im letzten Kapitel wird eingegangen auf eine Reihe anthropologisch relevanter Aspekte aus dem judischen Gedankengut. Einer dieser Aspekte ist, dass der Mensch geschaffen ist nach dem Bild Gottes, nach Seinem Gleichnis. Von Bedeutung sind die Willensfreiheit des Menschen und die Tatsache, dass er in seinem Handeln 'wie" Gott werden kann (Fromm). Der Mensch, der heil und gesund ist, kann seine Verantwortlichkeit in der Welt - in der Konfrontation mit dem Antlitz des Anderen (Levinas) - auf sich nehmen. 
Auch in der Medizin soll die Pflicht zur Verantwortichkeit und zu rechtem und rechtfertigem Handeln ein Kernpunkt sein. Es ist die medizinische "Halakha", die Anweisungen dazu gibt. Der Verfasser erortert dies in einem zweiten Teil dieses letzten Kapitels. Im dritten Teil wird nachgegangen wie Genesung in der Perspektive der Heilung gesehen werden muss und inwiefern dies einen erlösenden Charakter trägt. Der Kern dieses erlösenden Ereignisses - Antwort auf die Frage: 'wenn du auf der Suche nach dem Leben bist" - ist, dass es sich im Leben ausschliesslich um den Anderen handelt: "Du lehrst mich kennen den Pfad des Lebens" (Psalm 16,11).

Die Worte "Der Mensch wird am Du zum Ich" (Buber) und "Mein Ich entsteht im Du" (Rosenzweig) enthalten die Antwort auf die anthropologisch-medizinisch wichtige Frage "wenn du auf der suche nach dem Leben bist'. Man kann es nachlesen und horren in der Torah, in der schriftlichen wie inder mundlichen: "Alles ist in ihr erfasst" (Mischna, Abot V, 22). 
GEBRUIKTE AFKORTINGEN .
$\operatorname{ARN}^{1}$
Aboth de-Rabbi Nathan (version 1 ).
b. ben (zoon van).

Bab.Talm. Babylonische Talmoed, Talmoed Bavli.

Deut. Deuteronomium (Buber/Rosenzweig: Reden).

Enc.Jud. Encyclopaedia Judaica.

Enc.Talm. Encyclopedia Talmudica.

Ex • Exodus .

(Buber/Rosenzweig: Namen).

Gen. Genesis

(Buber/Rosenzweig: Im Anfang).

Jer. Jeremia.

Jer.Talm. Jeruzalemse Talmoed, Talmoed Jerusjalmi.

Jes. Jesaja.

Lev. Leviticus

(Buber:Rosenzweig: Er Rief).

Num. Numeri

(Buber/Rosenzweig: In der Wuiste).

Prov. Proverbs (spreuken).

Ps. Psalm.

R. Rabbi.

R. Rabbah (Midrasj Rabba).

Spr. Spreuken. 
VERKLARENDE WOORDENLIJST.

Achawaah, liefde, broederschap.

Adam, mens, de eerste mens.

Adama, akker, grond, aarde.

Aggada, vertelling. Die passages van de Talmoed en Midrasj die de Torah op verhalende wijze vertolken. Het betreft uitspraken, opvattingen, verhalen, legendes die geen halacha zijn.

Amida, lett.: staande. Ook Achttiengebed, Sjemone Esre of Tefilla genoemd. Een van de belangrijkste gebeden uit de joodse traditie. Het gebed wordt staande uitgesproken. Vandaar de naam.

Beraita, meerv. beraitot, lett.: er buiten staand. Uitspraken van Tanna'iem (schriftgeleerden die in de eerste eeuwen van onze jaartelling de Misjna samenstelden) die niet in de Misjna opgenomen zijn.

Ben, zoon van.

Beracha, meerv. berachot, bede, dankzegging, zegespreuk.

Bet ha-midrasj, huis van de uitlegkunde, leerhuis.

Bina, begrip.

Chaj, levend, in leven zijnd.

Chajiem, leven, de levenden.

Chassidiem, lett.: vromen. Ook: degenen die goede daden doen. Aanhangers van het chassidisme, een mystieke beweging in het jodendom. Chassied, lett.: een vroom iemand. Aanhanger van het chassidisme.

Cheroet, vrijheid.

Chesed, verbondenheid, trouw, solidariteit.

Choemasj, de Torah, de Pentateuch. De eerste vije boeken van Mozes.

Chokma, wijsheid.

Chtoewiem (ook: Ktoewiem), de Geschriften. Samen met de Torah en de Newie'iem de Tenach de Hebreeuwse bijbel, vormend.

Codex, handboek van de joodse levensleer (speciaal in de Middeleeuwen). 
Dawar, woord; ook: daad. Verder nog: ding. Derasj, uitleg. Aggadische uitleg van de Torah (zie ook pesjat).

Derech erets, lett.: de weg van het 1 and. Richtlijnen voor het juiste handelen in deze wereld.

Diaspora, verstrooiing. Joden die in de verstrooiing buiten Erets Israêl wonen.

Echad, één.

Emet, waarheid.

Emuna, vertrouwen.

Erets Israë1, Land van Israël. Galoet, ballingschap.

Gemara, lett.: aanvullende lering. Kommentaar op en uitleg van de Misjna. Misjna en Gemara vormen samen de Talmoed.

Gemilloet chassidiem, goede daden.

Geoela, bevrijding, verlossing.

Haggada, zie Aggada.

Halacha, lett.: weg, levenswandel. Meerv. halachot. Geaksepteerde levensaanwijzingen van de rabbijnen. De regels die bestemd zijn om in de praktijk te worden toegepast. Ook: het geheel van de joodse levensregels. Veelal in samenhang gebruikt met aggada (zie aldaar).

Haskala, Verlichting. Beweging die de moderne Europese kultuur in de tweede helft van de $18 \mathrm{Be}$ en in de $19 \mathrm{e}$ eeuw onder de joden verspreidde. Jachad, samen.

Jesjoea, bevrijding, verlossing, heil.

Jesjiva, hogeschool voor de studie van de rabbijnse literatuur. Talmoedakademie.

Jetser ha-ra, de kwade arijfveer in de mens.

Jetser ha-tov, de goede arijfveer.

Jichoed, eenwording, eenheid (zie ook jachad en echad).

Jir'aah, angst, vrees.

Jom Kippoer, Grote Verzoendag.

Kadosj, heilig, apart, afgezonderd.

Kasjroet, joodse spijswetten.

Kiddoesj ha-sjem, lett.: heiligen van de Naam. Heiliging van het leven. Strikt integere levenswijze en, in het uiterste geval, martelaarschap. 
Malkoet sjaddai, Koninkrijk van God. Mechilta (ook: Mekilta), lett.: maat, vorm. Midrasj-verzameling op Exodus. Me'od, zeer (goed), heel. Midrasj, lett.: uitleg. Rabbijnse vertolking. intepretatie. Rabbijns kommentaar. Zowel de wijze van vertolken als het resultaat ervan wordt midrasj genoemd.

Minjan, groep van tien mannelijke joden van dertien jaar of ouder. Het minimum dat verlangd wordt voor gemeenschappelijk gebed.

Misjna, meerv. misjnot. Lett.: herhaling van de leer. De oudste op schrift gezette halachische uitspraken (misjnot) van de mondelinge leer.

Mitswa, meerv. mitswot. Goddelijke opdracht, gebod. Bijbels of rabbijns voorschrift. Ook: goede daad.

Mitswot d'oralta, de voorschriften van de Torah.

Mitswot de-rabbanan, de voorschriften van de rabbijnen.

Newie'iem, de profeten. Samen met de Torah en de Chtoewiem de Tenach, de Hebreeuwse bijbel, vormend.

Pesjat, woordelijke uitleg van de Torah (zie ook derasj).

Pikoeach nefesj, het redden van het leven.

Rab, rabbi, rabbijn.

Rachamiem, barmhartigheid, medelijden.

Raw, rabbijn.

Reb, rebbe, jiddisch voor rabbijn. In het algemeen: leraar.

Refoea, genezing.

Rofe. arts.

Rosj ha-sjana, Nieuwjaarsdag.

Seder, lett.: orde. Deel van de Misjna of van de Talmoed (ook: de avond waarmee Pesach, het paafeest begint).

Siddoer, lett. : ordening, gebedenboek.

Sjaleem, (ge)heel, gaaf, volledig, wel, gezond.

Sjechina, Gods (verborgen) aanwezigheid in de wereld. 
Sjema, lett.: Naam. joodse levensbelijdenis, Deut.6:4, uitroepend de absolute eenheid van God (s jem=naam).

Sjemone Esre, het Achttiengebed (zie ook bij Amida)

Talmoed, lett.: leer, studie. De Misjna samen met de uitleg, verklaringen en kommentaren van de Gemara. Er zijn twee versies: de Babylonische Talmoed of Talmoed Bavli, en de, veel minder gebruikte, Jeruzalemse of Palestijnse Talmoed, De Talmoed Jeroesjalmi.

Talmoed Torah, het leren van de Torah, joods Ieren.

Tamiem, heel, gaaf, integer.

Tenach (ook: Tenak), de Hebreeuwse bijbel, bestaande uit de drie delen: Torah, Newie"iem en Chtoewiem.

Tesjoeva, ommekeer; ook: antwoord.

Toharot, reinheidsregels. De zesde seder van de Misjna en de Talmoed.

Torah, lett.: lering. Levensleer, het geheel vande traditionele joodse leer en joodse literatuur. Onder "de Torah" worden de vijf boeken van Mozes (Genesis, Exodus, Leviticus, Numeri, Deuteronomium) verstaan.

Torah sje'be'alpe, de mondelinge Torah. Torah sje'bichtav, de schriftelijke Torah. Tosefta, lett.: toevoeging. Toevoegingen van de schriftgeleerden op de Misjna.

Tsaddiek, lett.: rechtvaardige. Chassidische rabbi.

Tsedaka, rechtvaardigheid, gerechtigheid. Tsédek, rechtvaardigheid. 
H dexth, Heman van, en Hane Hollenbeek Browwer, Syllabus Metho-

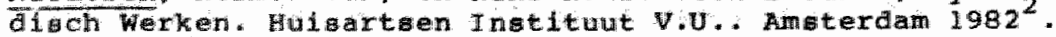
Aald A.J. van der. Aantekeningen blj de hellenibering van het Thidendom. Wifmegen-Den Hag 1974. Aboth de-Rabb1 Mehin (version 1, ed.schechter, 1887, ARk'); The Fathere afeording to Rabbl Nathan (tranal.judah Goldin). New work $195,1974^{2}$

Abraham, Abraham 5 . Mealcel halachah for everyone. A comprehensve guide to Jewilh medical law in sicknegs and health. JerusaLem-wew 1980 .

Abram, I.B.H. Joodse tradite als permanent leren (diss.). Hilversm 1980 .

Abram, I.B.H. Jodendom en permanent lexen. In: Id. e.a." Beth ha-MIdras - Iferhuls. Ervaringen van Joden en Chrigtenen. Kampen 1983.

Aaxiadnge, H., M.J. Drop, R. Halfens, H. Philipsen, Leeft NederIand oke? verag van een onderzoek nar de beleving, opvatingen en gedragingen inzake gezondheid. Mastricht-zeist 1981.

Anir, Yehoshua, 50 Jahre nach dem Tod von Frarz Rosenzweig In: Felburger Rundbrief XXXI/1979,117/120,24-26.

Amir, Yehoshum, Das pezifisch Jialiche im Denken Rosenzweigs. In: Rlchard schaeffer u.a., Offenbarung im Denken Rosenzweigs. Essen $1979(\mathrm{~b})$.

Antonoviky. Aaron, Healtg, stres and coping. San Francisco-Washington-London $1979,1980^{2}$.

Arke1, D. wan, over ontwikkeling en gevolgen van het westers tijdabewustzijn. In: De Gids $1974,9 / 10,609-619$.

A echkenasy. $Y$, Vexhal. In: L. Lubbers, De latste dingen. Een pedagogisch-humanistische bezinning omtrent leven en sterven. Nijkerk 1978 .

Achkenasy, $Y$, en D.J. van Uden, De messiamse verwachting in het Jodendou. In: $Y$.Aschkenasy e.a., Geliefd $1 \mathrm{~s}$ de mens. Hilversum $1981,116-130$.

Aschkendey, $Y$, en W.A.C. Whitlau, Joodse hermeneutiek. In: id. e. Geldefd is de mene. Hilver un $1981,25-39$.

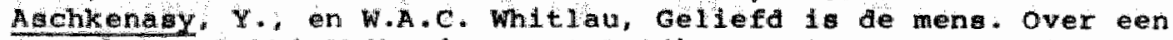
Bpreuk van Rabbi Akiba (Avoth III,14). In: id. e.a., Geliefdis de meng. H1 lveram $1981,7-24$.

The Babylomidn ialmud, Trandated into English with notes, glossary and Indlce under the editorahip of Rabbi Dr. I. Epstein. London $1935=1952,1961,1978$

Dadt-gtrauss, Bertha, Wort des Gedenkent. In id. u.a., Franz Rocentwig. EIn Buch des Gedenkens. Berlin 1930,5-7.

Bask, Leo, Das Wegen des Judentumb. Frankfurt am Man 1906-1926. Baggen, J. In., De onnogelijkheid vart hulartsgeneeskunde in onze hedendagie westerse cultuur. In Medisch Contact 31,1976,10331038 .

Bakker, R. Niet Ik, mar de Ander. De fllosofie van Levinas. In: Trour, 27 januar 1977 .

Bakker " Wijsgerige antropologie van de twintigste euw. Asan 1981. $\frac{\text { Balint }}{\text { pen } 1965 \text {. }}$. De dokter, de patient, de ziekte, utrecht-Antwer-

Baruch, J. 2 , ceneegunde in het oude Israel. Amsterdam 1961.

Bajgakenpakket van de huisarts. Rapport Landelijke Huisartsen 
Vereniging. Utrecht 1983.

Beek, M.A. en J. Sperna Welland, Martin Buber. Barar 1964. Beeriling . R.F., De tija, ons een zorg. In: De Gids 1974,9/10 643658.

Bein, Alex, Die Judenfrage. Biographie eines Weltproblems I, II. Stuttgart 1980 .

Ben-Chorin, Schalom, .... En schlep hen nar zijn beeld. Een joodse visie op de lichamelijkheid van de mens. Baarn 1973.

Ben-chorin, Schalom, Jlkdischer Glaube. Strukturen einer Theologie des 2 Judentums anhand des Maimonideschen Credo. Tubingen 1975 , $1979^{2}$

Ben-Chorin, schalom, "Dein Relch komme". Reich-Gottes-Erwartungen in Jưdischer und christlicher Sicht. In: Hans Hermann Henrix, Unter dem Bogen des Bundes. Aachen 1981 .

Benjamin, Walter, Illuminationen. Frankfurt am Main 1961 . Benthem van den Bergh, G. van, Inleiding. In: De Gids 1974,9/10, 597-599.

Bergma, Jurrit, De huisarts in de storm. Opmerkelijke felten over de huisartsenpraktijk. In: Intermediair 17,1981,20.

Berkovits, Eliezer, Rabbijnse gedachten in verband met Jeruzalem.

In: Gesprekken in Israël (Nes Ammim), 7, 1980,4-22.

Bernant. Chaim, Joods gezinsleven. Traditle en levend heden. Ame-

Fongen 1976 .

Bernstein, Judith, Aaron Antonowsky, Lechaim Naggan, Community

Health orientation in the curriculum of the school of Medicine. Ben-Gurion University of the Negev. Beersheba 1980 .

Bleich, J.David, Contemporary Halakhic Problems. New York 1977. Bleich, J.David, Judaism and healing. Halakhic perspectives. New York 198.1.

Bochenski. I.M., Geschiedenis der hedendaagse Europese wijsbegeerte. z.p. 1952.

Boer. A.A. de, Wijsheid en verhalen uit de Babylonische Talmoed. Assen-Amsterdam 1976.

Boer. Theo de, Tussen filosofie en profetie. De wijsbegeerte van Emmanuel Levinas. Baarn 1976.

Boertien. M. Het Joodse Leerhuis van 200 vobr tot 200 na Christuis. Kampen 1974.

Bolinow, otto Friedrich. Nieuwe geborgenheid. Een bijarage en

overwinning van het existentialisme. Utrecht $1958,1967^{2}$.

Boman, Thorleif, "Das hebrtische penken im Verglelch mit dem griechischen. Gottingen $1952,1977^{\circ}$.

Boon, Rudolf, ontmoeting met Israji. Het volk wan de Torah. Kampen 1974 .

Boote. J.M.J., Het werk van de huilarta. Result ten var een funktie-analyse in 93 hulsartspraktijken (diss.). Mastericht 1983. Bouckaert, Luk, Emanuel Levinas. Een fllosofie van het gelat. Nijmegen-Brugge 1976.

Boxel, piet van, Je zult achter de Heer je God aamandelen. Met rabiljnen de bijbel lezen. Hilversum 1982 .

Brachfeid, Sylvain Salomon, Uw joodse butrman. Antwerpen-Amsterdam 1975.

Breek, B.; Over het probleem der joodse wijbbegeerte. In: Tijdschift woor Filosofie $34,1972,2,227-281$.

Breung, Gepa, Geneeskunde. Een verkenning van een toeribt. Alphen aan de Rijn-Brusgel 1980 .

Brouwer, W., Frvaringen met psycho-sociaal-anamnestisch onderzoek als diagnostisch hulpmiddel in een huisartsenpraktijk (diss. Groningen). Finmeloord 1962 .

Bruin. Tom de (amenstellex). Adam war ben je? De betekenils van het mensbeeld in de joodse traditie en in de psychotherapie. Hil- 
Weraum 1903

Eubar. Matin, Daniel. Gesprache von der Verwiklichung. Leipalg TII3.

vuber. Matin, Der hellige Weg. Ein wort an die Juden und andie Whlkr. In id. Reden fuex das Judentum. Frankfurt am Main 1923. Buber, wartin, Dje chasidichen Bther. Beriln 1927.

Fuber, Martin, Das Juaentum und ale neve Weltfrage. In: ld., Kampi um Iare 1 . Reden und schriften 1921-1932. Berlin 1933,21-28.

Eubex. Mrein. Die Eennpunk der Judachen Seele. In: id., Kampt um I rati. Reden und Schriften 1921-1932. Bex1in 1933, 50-67.

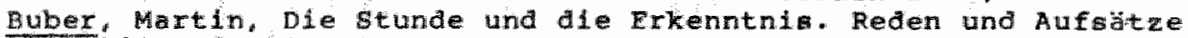
$1933-1935$. Berifin 1936 .

suber. Martin Ich und Du. In: id., Dialogisches Leben. Gesammelte philosophiche und padagogische schriften. zurich 1947 .

Buber, Martin, Da Problem des Menachen. In: id. "Dialogisches

Leber. Gesammelte philosophisehe und padagogische schrifter. Zurich 1947 .

Euber, Martin, Was ist zu tun?. In: id, Hinweise. Gesammelte

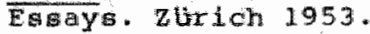

Euber, Martin, schuld und Schuldgefthle. Heidelberg $1958,1977^{2}$

Took in: Sborowitz en in: De Bruin. zie aldaar).

Buber, Martin, Chassidiache vertelingen. Katwijk 1967.

Buber. Martin, De weg van de mens volgens de chaosidische lëer.

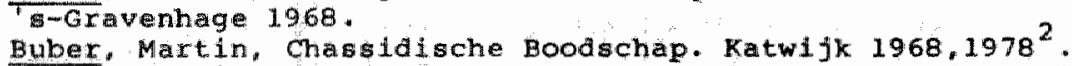

Buber, Martin, voordrachten over opvoeding en autoblografloche Eragmenter. Utrecht 1970 .

auber, Martin, Das dialogische Frinap. Helselberg 1973 $3^{3}$ Herin ZIn opgenomen. 1.Ich und Du (1923), 2.2w1esprache (1930).3.01e Frage an den Elmzelnen (1976). 4. Elemente des zwischenmenschlichen (i95), 5 . Nachwort $(1954)$.

Buber. Martin, zu einer neuen Verdeutachung der Schrift. Beilage zum ersten Bana 'Die flinf Blicher der weisung'. Heidelberg 1979" Buber/Rosenzwelg, Die Schrift. zie ldar.

Buma, J.T., De hulgarts en z⿺jn patient. Grondsiagen van het medieh denken en handelen. Amsterdam 1950 ,

Burggraeve, Roger, Ethische grondslagen voor en menswardige samenleving. De bijdrage van Emanuel Levinas. In Ethische vragen voor onze tija. Antwerpen-Amsterdam 1977 .

Burggraeve, R., Van zelfontplooilng naar verantwoordelijkheid. Fen thische lezing van het veriangen ontmoeting tusen pyehomalyse thi Leving. Luver 1981 .

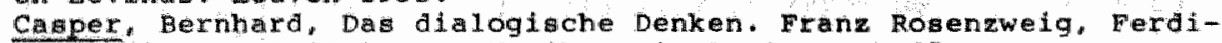
nand Ebnex, Martin Buber. Frelburg in Brelegau 1967.

cassee, wout mh. Enkele achtergronden van ziektegedrag en gezondhe datorg. Mepped 1973 .

Cagyko, U., A commentary on the book of Exodus. Jerusalem. 1951 , $1.974^{6}$

Chouragul. A. Leven voor Jeruzalem, Hilversum 1979.

Cohen. "Everyman Talmua. London 1932.

Cohen, Hermann, Reilgion der vernunft as den quelien des Juden-

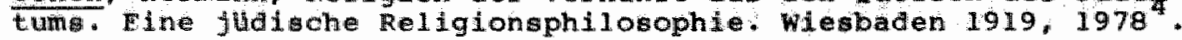
Cohon. Samuel $\mathrm{s}$. Jewilsh theology. A historlcal and systematic Interpretation of judaism and 1 to foundations, Assen 1971. Danby, Herbert (ed.). The Mishnah. Zie aldar.

Dasberg, Lea, Padagogie in de schaduw van het jaar 2000 of hula arn de hoop. (17ug rede). Meppe1-Amoteram 1980.

Dilogue between Martin Buber and Carl Rogers Int Payohologia. An International journal of psychology in the orient. vol.3. kyoto (Japan) $1960,208-221$ (ook in De Bruln 1983,239-256).

Dlepen, Rudolf, Lelb, Peran, Rrankhelt. Antropoliache Gedanken. 
In: Giessener Hochschulblatter 8,1961 .

Dokter. H.J.. Tat een hoeksteen. Am terdam 1973.

Draper, peter and Fslen L.Smits, The primary-care practitioner

- specialist or jack-of-ali-trades. In: The New England Journal of Medicine, October 30,1975,903-907.

Dresden, S.. Het Einde (afacheidacollege). Den Hag 1980.

Drijvers, Pius, op zoek nat de Alef. Verkenningen op het gebled van de Joods-christelijke schriftbenadering. Hilversurn 1983 .

Dubois, Jacques Marcel, Gemeinsames Bezeugen des Gedenkens und der Hoffnung. In: Freiburger Rundbrief XXXII/1980,121/124,42-48. Ebner, Ferdinand, Das wort und die geistigen Realitaten. pneumatologiache Fragmente. Innsbritrk 1921.

Ehrlich, Ernst Ludwig, Die 10 Gebote - aktuel1. Wien 1978.

Ehrlich, Ernst Iudwig, Die 10 Gebote. In: Gothold Milder (Hisg.), Israel hat dennoch Gott zum Trost. Festschrift fur Schalom BenChorin. Trier $1978(\mathrm{~b})$.

Elke Morgen Mieuw, Inleiding tot de foodse gedachtenwereld aan de hand van een van de centrale joodse gebeden. 'sjemone Eare' of Achttiengebed. Samengesteld doox D.J.van der sluis, P.J.Tomson, D.J.van Uden en W.A.C.Whitlau. Hilversum 1978 .

Encyglopaedia Judaica, Val.1-16 and 5 Vol.suppl. Jerusalem 1972, $\sqrt{978^{4}}$.

Encyclopedia Talmudica, Vol.I-III. Jerusalem 5729(1969)-5734(1974) $5739(1978)$.

Fpstein, I. (ed.). The Babylonian Talmud. Zie aldar.

Epstein. I sidore, The falth of judalsm. An interpretation for our times. London-Jerusal em-New York $1974,1980^{6}$.

Epstein, Isidore, Judaism. A historical presentation. Baltimore 1959,1960 .

Epstein, I sodore, Geschiedenis van het jodendom. Utrecht-Antwerpen 1964 .

Es, J.C. van, Mogelijkheden van de huisarts als gezondheldubevorderaar. Handelingen van het 28 Ledencongres der K.N.M.G. (II). In: Medisch Contact $31,1976,1357-1363$.

Es, J.C. van en R.A. de Melker, Wat voor gezondheldszorg wllen wij? In: Medisch Contact 33,1978,961-965.

ES. J.C. Van, Patiënt en huliarts. Een leerboek hulsartsgenesskunde (tweede, geheel herziene druk). Utrecht 1980 .

Es. J.C. van, Levensloopgeneeskunde en de diagnastiek van de

huisarts. In: Huisarts en wetenschap $26,1983,62-65$.

Es, J.C. van. Hularts en leven loopgeneeskunde. In: Nieuw konpas voor de huisarts. Lefirad voor de praktijk met huisartgigeneeskundige methoden en praktiache informatie. Utrecht-Antwerpen 1983 , $I I / 3$.

Es. J.C. van, R.A. de Melker, F.C.L. Goosman, Kenmerken van de hulisarts II. Utrecht-Antwerpen 1983 .

Eijk, J.Th.M. van, Lewenggebeurtenissen en ziekte. Een verkennend onderzoek nar het effekt van enkele levenggebeurtenisen op het ontstaan van zlekte bij personen met een terk en zwak probleemoplossend vermogen (diss.). Wijmegen 1979 .

Farber, Lesile H., Martin Buber und die Psychotherapie. In taul Arthur Schilpp und Maurice Friedman (Hg:), Martin Buber. Stuttgart $1963,508-531$.

Feldman, David M., Marital relgtione, bleth control an abortion in Jewish 1 aw. New Xork $1968,1978^{3}$.

Fortmann. Han, Wat is er met de mens gebeurd? over de taak van een vergelijkende culturpsychologie. Bilthowen 1959,1971 8 .

Fortgann, Han M.M., Als ziende de onzienIljke II. Hilversum 1968, $1974^{2}$.

Fortmann, Ean, Heel de mens. Reflektles over menselijke mogelijkheden. Bilthoven 1972 . 


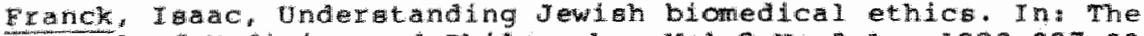
Journal of Mediclne and Philogophy. Vol.B,Ho.3,Aug.1983,207-224. Fank1, viktor . De zin wan het bestan. Een inieiding tot de logotheraple. Roterdam 1978 .

Frank1, Viktor E., De wil invol te leven. Lagotherapie als hulp In deze tida. Roteram 1980.

Funl. Viktor E. Heet het leven zinz Fen moderne psychotherapie. Rotterdam 1981 .

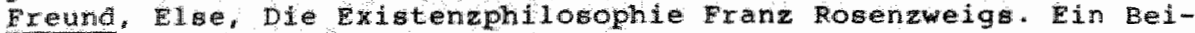
trag zur Anelyse seires Werkes "Der stern der Erlobung" Hamburg 1959

Exidentald, Hary, The Jews and medicine. Vol.I-II. New Hork 1969 .

Friedlander, Abert : Die Exodua-Traition. Geschichte und Hellogemichte aum Jualecher sicht. In: Hang Hermani Henrix/Martin stohr (Hg.), Exadus und Kauz Im Bkmenischen Dialog zwischen Juden urd Ghisten. Aachen $1978,30-44$.

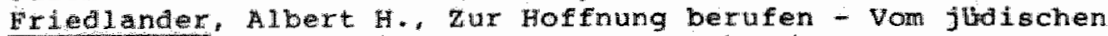
Glubenweg. In. Hanb Hemann Hentix (Hg.), Unter dem Bogen aes Bundes. Aachen 1981 .

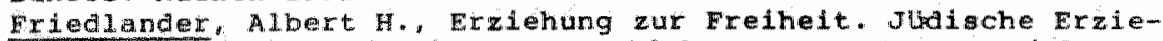

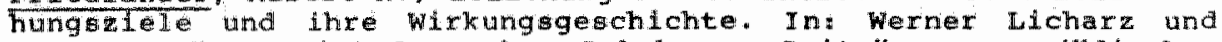
Martin stohr, Einjadurg ing Lehrhaus. Beitrage zum jlisishen Selboteratandnis Frankfurt am Main $1981(\mathrm{~b})$.

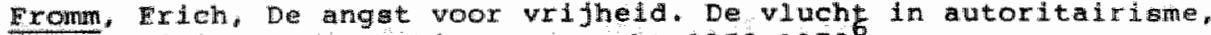
dentructivine, conformiane. Utrecht $1952,1972^{6}$.

Fom, wich, Het hart van de mens. onze geneigaheld tot goed en kinad, utrebrit 1982 .

Fomm, Eich, Gij zult zijn als goden. Een radical humanlstiche interpretatie van het oude Tetament. Utrecht 1975 .

Fy. John (t.), Primary Care. London 1980.

De funkteomschr1julng wan de huisarts. Landelijke Huleartgen

Vereniging "Utrecht 1981.

Gadourek, I. Socialogische onderzoektechnieken. Inlelding tat de wexkijze bij het socia 1 en gedragswetenschappelijk onderzoek. Deventer 1972 .

Gedragregello voor Arten. K.M.M.G. Wtrecht 1978 .

Geug, C.A. de, Huisart, Matechappij en Wetenechap. In: Huisarts ar Weterischap $16,1973,251-256$.

Geus, Co. de, Bagle Patentenbetreung. In: Der Praktische Arzt $21,1974,253-2543$.

Qeus, $C$. de, Mul artsgeneegkundig handelcn. In: Nieuw kompa

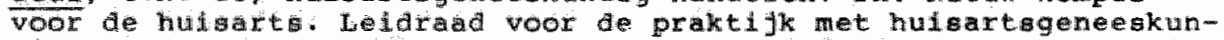
dige methoden en praktische informate. Utrecht-Antwerpen 1983 , III 1 .

Q1mzberg, Woul The Legenda of the Jews. Vol.I-VII philadelphia $5727-5730 / 1967-1969$.

ginaberg, Wowis, Jewilh thought as reflected in the Halakah. In: Judah Goldin (ed.), The Jewdih expresion. New Haven-London 1976. Q.1.tes, Nahum Norbert, Geschichte der talmudischen zeit. Berlin 1937, Weukit chen-U1uyn, 1901 .

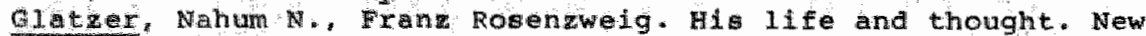
101K $753,192$.

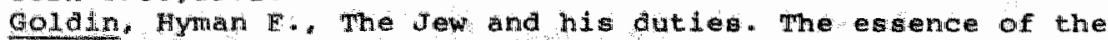
Kiturix shulchan Aruch. New York 1953.

goldin, Juck (tranal.) Aboth de-Rabbi Nathan.zie aldar.

GoldIn, Matin p., preventive vs. curative medicine perspectives of the Jewish legal tradition. In: The Journal of Medicine and Ph110sophy * Wo1.8, No.3. Aligugt 1983,269-286.

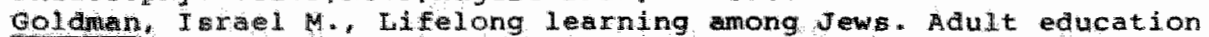
Jin Jud am rom biblical times to the twentieth century. New York 
1975.

Goldochmidt. Herman Levin, Dile Botschaft des Judentums. Grundbegriffe, Geschichte, Gegenwartsarbelt, Auseinandersetzung. Frank-
furt am Main 1960 .

Gordon, Harry H., The doctor-patient relationship. In: The Journal of Medicine and Philosophy, Vol1.8, No.3, August $1983,243-256$. Gorfinkle, Joseph I. (ed.). The eight chapters of Maimonides on ethics (Shemonah Perakim). New York 1966.

Gottlieb, Danlel, Man and God: a Jewish pexspective. In: SIDICService international de documentation judeo-chretienne lenglish eaition), Vol.XII, Nos 1, 2, 1979,52-58.

Goud. J.F., wat men van zichzelf eist, eist men van een heilige. Een gesprek met Emmanuel Levinas I. In: Ter herkenning 11,1983. $2,19-24$; id. II, in id.,1983,3,49-57; id. III, in $10 ., 1983,4,82-$ 87; id. IV, in id.,1983,5,147-154.

Grayzel, Solomon, A history of the Jews. From the Babylonian exile to the present. New York 5728/1968.

Groot, A.D. de, Methodologie: Grondslagen van onclerzok en denken in de gedragswetenschappen. 's-Gravenhage 1961,1970".

De Grote oosthoek. Encyclopedie en woordenboek. Utrecht 1976-19817 Grinewald, Hans I.. Die Lehre Israels. Bemerkungen, Erklarungen und Hinweise zu den wöchentichen Lesungen der Juden aua der Thora. München-wien 1970 .

Guttmann, Julius, Philosophies of judaism. The history of jewish philgsophy from biblical times to Franz Rosenzweig. New York 1966.

Haggada (Seder-Haggada), z*p. $5731,5743^{3}$.

Hamel, B.Remno, Abraham, een mens op weg.... 's-Gravenhage 1981 . Hamminga, $H .$, Levinas en het menselijk gelaat. In: Metamedica $50,1971,10,289-294$.

Hartingsveldt, P.C. van, De verdeelde mens nader beschouwd. Geneeskunde, ethiek en filosofie. In: Intermediair 17,1981,16,4954.

Hartman, gavid. Torah and philosophic quest. Philadelphia $5737 /$ Gartman, David, Joy and responsibility. Israel, modernity and the renewal of judaism. Jerusalem 1978.

Hartman, David, Moral uncertainties in the practice of medicine: the dynamics of interdependency from a halakhic perapective. In: The Journal of Medicine and Philosophy, Vol.4, no.1.1979,98-112. Hartman, David, Creating space for the integrity of the other. An educational challenge for Jew and Chribtians. In: SICIC-service international de documentation judeo-chretienne (english edition). Vol. $X_{\text {N }}$ no. $2,1982,5-10$.

Bartmann, Fritz, Aerztliche Anthropologie. Das Problem des Menschen in der Medizin der Neuzeit. Bremen 1973.

Hartmann, Helnz, Empirisch soclat onderzoek. Utrecht-Artwerpen 1973.

Hasselaar, J.M., Inleiding tot het denken van E Rosenstock-HuevSY. Barn 1973 .

Have, Henk ten, Geneeskunde in de splegel der historie I. In:

Metamedica 61, 1982, 106-115.

Heering, H.J.. Franz Rosenzweig. Joods denker in de twintigste euw. s-Gravenhage 1974 .

Heering. H.J." Die alten fthischen Worte. Over Franz Rowenzweilg als joods filosoof. In: Tijdschrift voor filosofie 38,1976,4, $535-558$.

Heidegger, Martin, sein und zejt. Tubingen $1976^{13}$.

Hertz, Joseph $H$. (ed.), Sayings of the Father or Pirke Aboth. New York $5.705 / 1945$.

Heschel. Abraham Joshua, Man is not alone. A philosophy of reli- 
gion. New rork $1951.1977^{2}$.

Hesche1, Abraham Jgahu, The sabath. It meaning fot modern man.

New Work $1951,1977^{3}$.

Hegche1, Abraham Joghua, God in search of man. A philogophy of

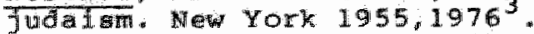

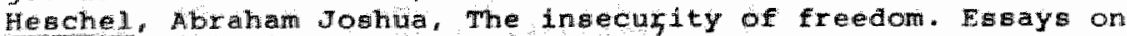

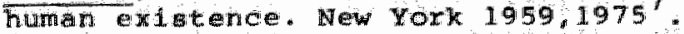

Hesche1, Abrahan J."The prophets. vol.1. Waw York 1962,19692.

Terehe1, Arraham I.. Wo Is Man? Stanfora 1965.

Wesche1, Alrahan Joahwe, The concept of man in Jewish thought. In:

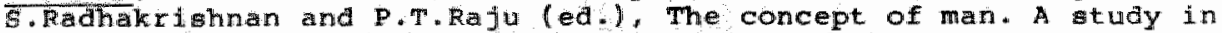
comparatue philosophy. London 1966,108-157 Cook in Tom de Bruin, $(35-8 \mathrm{~B}$ te adar).

Heschel, Abraham Joshua, A pasion for truth New York 1973 , $197 \%$

Hitach, Samon phael (trang1.), The Pentateuch. zie aldaa. Hoe helpt de dokter? Hulartageneeskunde als onderdeel wan de eretelijns hulpverlening. NHG-rapport, utrecht 1975 .

Hoven, J.A. van der, Hippokrates. Arte en Ethiek. Lejden 1963. Hoeven, J.A. van der. Het gehel 1 a meer an de gam der delen. Een Winleding tot de peychosomatiche geneeskunde. Leiden 1965.

Holten-Vriesema, J., $C$, Tompot, H, van Aalderen, $K$. Blanken, J. Tbellings, $F_{*}$ Riphagen, $K$. Scholwstra en G. Venhoret. Methodisch werken over en algemene methode van hulpuerlening en de opbouw van en funkionele relatie, coegespltat op de hula artepraktijk. In: Hulartis an wenschep $21,1978,322-335$.

Moog, P.H. van dex, Rabbi Mozes ben Malmon. Den Hag z.j. Herst, $F$, var der, W. Vierhout, , stalenhoef, Probleemgeorienteerde vers aglegging in de huisartspraktijk 1 ; ervaringen. In: Hulsarts wetenschap $24,1981,252-258$.

Horst, $F$, van der, w. vierhout en W. Meulders, Probleemgeoridnteerde versiglegging in de hulsartapraktijk 2; analyse van even congult. In: Huisarts en Wetenechap $24,1981,325-331$.

Horwitz, Rivka, Buber's Way to "I and Thou". An historical analywis and the first publication of Martin Buber"s lectures "Religion als Gegenwart" Heidelberg 1978 .

Hurwitz, Shimon, Being Jewish. Jerusalem $1978,1981^{3}$.

Huygen, F.J.A. Family medicine. Nijmegen 1978 .

Huygen, F.J.A." paradigma" s voor de hularartggeneeskumae. In: Huisart en wetenschap 21,1978 (b), 44-450.

Hymar, Arthur, De joodse fllosofle. In: Elle Kedourie (red.). De Joodse wereld. openbaring profetisme en gerchiedenis. Antwerpen $1980,209-216$.

Ilar. Yehtel. Theologiohe Apekte des Holdcaust. In: Freiburger

Rundbr lef XXXI I $/ 1980,121 / 124,33-40$.

Jacobopin, Dan, The story of the etories. The chosen people and its God. London 1982 .

Takobovita. Immanul. Jewioh medicalethlea A conparative and hitorical study of the Jewish religion attitude to medicine and ite practice. Rev. Ed. Wew York 1975.

Jakobovlts, Tmanuel. The tlmely and the timelese. Jews, judalsm and society in a sorm-tosald decade. London 1977 .

Iakob. Louis, we have reason to belleve some aspects of Jewish thaojogy examined in the light of modern thougt. London 1957 , 1.963

Karle, R., wat is (zomer)tija? In: Intermediair 13,1977,13.17-21. Kaduhin, Nax, organje Jhinking. A stuay in rabbinic thougt. New Totk 1938 .

Kedushin, Max, The rabbluid mind. New York 1952,1972.

Kadustin, Max, Worship and Ethics . study in rabbinic judaism.

New Tork 1963 . 
Kahn, Isodoro, The Sabbath in Jewish life. In:STDLC-serulce International de Documentation judeo-chretienne (angligh edition Vol. $x, n 0.1,1977,4-7$.

Kaplan, Aryeh, The handbook of Jewish thought. New Wom-werusalem 1979

Keller, werner. .. En zij werden verstrooid onder alle wolken. De geschiedenis van het jodendom na het bijbelse tijdvak. Twolle $z$. Kimsma, G.K. en H.A.M.J. ten Have, De arts-patidntrelatie tussen beeld en werkelijkheid. In: Medisch contact 6, 1984,173-177.

Kreidler, Eugene, Joods-christelijke dialoog en chribtelijke theom logie. In: Gesprekken in I Bräl (Nes Amim), 9, 1983-1984,3.

Kuiper, J.P., Het zal onze zorg zijn. Inleiding tot de gezondheldkunde: basis vari een inclusieve gezondheidsoorg. Assen-Amsterara 1975

Kuiper, J.P., De betrekkelijke warae van gezondheid en gezondheidszorg. In: Medisch Contact 33,1978,1019-1025.

Kuiper, J.P., Mensopvatting en gezondheldszorg. Asseng1980.

Kuiper, P.C. Nieuwe nevrosenleer. Deventer $1966,1984^{8}$.

Kwant, R.C. De verhouding van mens tot mens volgens Emmariuel

Levinas. In: Streven 19,1966,4,609-621.

Kwant, B.C., (red.), Mensbeelden. Filosofie in en plutiforne samenlieving (tweede druk). Alphen aan de Rijn 1979.

Lamberts. H., De groepspraktijk en de geestelijke gezondheldszorg

in Ommoord. In: Fuisarts en wetenschap 13,1970,363-369.

Lamberts, a. an J.M.H. op't Root, Het matichappelijke werk in de groepspraktijk Ommoord. In: Huisarts en wetenschap 13,1970,450461.

Lamberts, H*, Redenen om nar de huisarts te gaan. Eerste ervaringen met de Reason for encounter classification. In: Huisartsen Wetenchap $25,1982,301-310$.

Landau, Jecheske1. De drie dimensies van het joodse geloof - I tesedaka" . In: Gesprekken in Israèl (Nes Ammim).9,1983-84.1. Landmann, Michael, Filosofische antropologie. Utrecht-Antwerpen $1966-19722^{3}$

Lapide, Pinchas, Uit de bijbel leren leven op joodse wijze de schrift lezen. Barn 1984.

Laterbach, Jacob, 2 . (transl.), Mekilta de-Rabbi Ishmael. Zie aldar.

Lee, Philip R. and Patricia E. Franks, Health and disease in the community. In: John Fry, Primary care, London 1980,3-34.

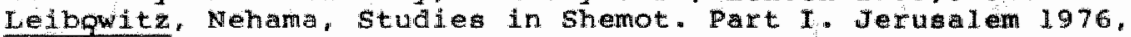
$1978^{2}$.

Lelbowitz, Nehama, studies 1n Devarim. Part II, Jerutatem $5740 /$ 1980 .

Lewinas. Emmanel. Het menelijk gelaat. Egsays. Gekozen en ingeleid door Ad Peperzak. Bilthoven $1969,197 \mathrm{l}^{2}$.

Lewinas, Emmanuel, Totalite et Infini. Esoa sur 1 exteriorite. La Haye 1974 .

Liberan Jodendom (Brochure Verbond yan libera 1-religieuze joden in Nederland). Amsterdam $5741-1981$.

Loen, A.E., De geschiedenis. Haar plats, zijn, an en kenbaarheda. Asten 1973 .

Macooby, Hyam, De bijbel. In: Elie Kedourie, De joodse wereld. Openbaring, profetisme en geschiedenil. Antwerpen 1980,52-67. Mamonides, Mozes, The Guide of the perplexed. Vol.I-II (tranel. by Echlomo pines). Chicago and London 1963.

Marcel, Gabriel, De mens, zichzelf een vragstuk Utrecht 1956, $1969^{-1}$

Mayer, Reinhold, De briefwisseling van Franz Rowenzwelg met Eugen Rosenstokk. Ower de betekenis van het jodendom voor de christenheid. In: wending $21,1966,9,626-643$. 
Mayer, Helnhola, Eranz Roserizelg. Ene Phllobophie der dialoGiohen Erfahrung. Mtmehen 1973.

Medalie, Jack H. Eamil medicine - principles and applications. Baltimore 1978.

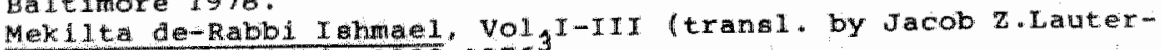
bach . Philadelphia $1933,1976^{3}$.

Melen, A.G.M var De kracht en de zokte van de naturwetenshappel Jk georienterae geneedkunde. In Metamedica 62,1982 ; $264-271$.

Menges, L.J. 01tzicht op morgen en psychosociale bijarage tot Je integrale geneeskunde ijkerk 1971.

Menged H.J. Kijker nar gezondheld en ziekte. Alphen an de R1jn-Brusel 1980 .

Mche1, Enst, Retung und Erreuexung des personalen Lebens. Frankurt am Man 1951 .

MJarach Tanhuma B (Hans Dletenhard) "Berr-Frankfurt am Main-Las Vegas, Ho. 1960, Bd.2 1982 .

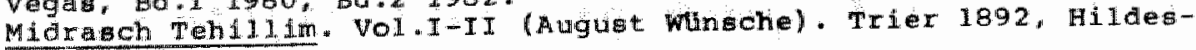

heim 1967 .

The Madrah abbah. Vol. I-V (ed. H. Exeedman and Marice simon). London-Jervalem-1ew York 1977 .

Mielzlner Moses, Intwoduction to the Talmud (1894). New York 1968

Mitrande, F. de, ontmoeting en verwachting . Bifbel getulgenis vanal Kain tot and de Godsknecht ult het boek Jebaja. Utrecht 1968 .

Miranda, $F$, de, Het hellige en de mens. Religleuze en priesterTijke werkelijkheidsbepaling. Religle als tichtingsbepaling. (diss. Nijmeganl. Wasenar 1979 .

Miranda, F. đe, Uitwerkiezing. 's-Gravenhage 1983.

The Mishnah, Translated fron the Hebrew with introduction and brief expianatory notes by Herbert Danby oxford-London 1933$1944^{3}$.

Misktte, K.H. Het wezen der joodse religie. Harlem 1932, $1964.278-370$

Mol1. I. Twe-componenten geneeskunde In: Intermediair 14, $1978,33,39-47$.

Montefiorg, C.G. and H. Loewe, A rabblnic anthology. New York 1974.1978 .

Moses stephane, systore et revelation. La philowophie de Franz

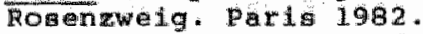

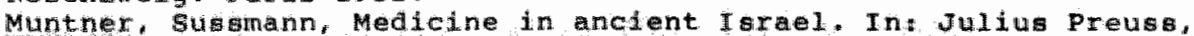
Bibliseh-talmudsche Med1zdn. New York 1971, XIII-XXXII.

Murz, J., Moges ben Matmon (Matmonlde ). Sein Leben und seine

Werke. Frankurt arain 1912 .

Nave Levinson, Pnina, Dincthrumg in ate rabbintsche Theologie.

Dring tot 1982 .

Weusner, Jacob, Hitory and Torah. Esays on Jewish learring. New York 1965.

Neugner, Jacob. Talmudc Law and exiticiam in judaim. Int SIDICServed liternational de documentation judeo-chretienre. (english

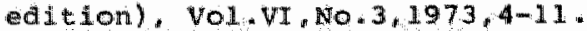

Neusnex, Jacob (a)), Understanding rabbinic Juda am. From ta 1 mudic to modern times. New York 1974 .

Neurner, Jacob, Lern MLhnah. New York 1978.

Noughe, Jacob, Learn Talmud. New York 1979.

Neusner, Jacob, Meet our Sages. New York 1980 .

Newine Loud ult de wereld der joodse mystiek Katwijk 1976. WIJ or Jan, De sociale voorschilften in de Torah. Genk 1979 . OlIemans, A.P. Morbiditelt in de hulartaprakt ljk. Leiden 1969. OnderwIJex, A.S., Nederlandse vertaling van de pentateuch met 
Rashie ' Pentateuch-kommentaar. Amsterdam $5657 / 1897,1977^{3}$.

Palache, J.L., Inlelding tot de Talmoed. Amstelver $1980^{3}$

Peli, PAnchas Hacohen, Flear O Israel: Winess to the one cod. In:

SIDIC-Service International de Documentation judeo-chrêtilenne

(english edition). Vol XVI, 2, 1983,4-8.

The Pentateuch, translated and explained by samson Raphael Hirsch. VoI.I-V. Frankfurt am Main 1893. Gatesway 1976.

Petitdemange, Guy, Franz Rosenzweig. In: Esprit, 5, 1979, 28-39.

Petuchowski. Jacob J., Es lehrten unsere Meister... Rabbinische

Geschichten. Frelburg-wien 1979.

Petuchowski, Jacob J., Ansätze zu einer jlidischen Theologie des

Christentums. In: orièntierung $44,1980,21,231-234$.

Petuchowski, Jacob J.. Wie unsere Meister die schrift erkluren.

Beispielhafte Bibelauslegung aus dem Judentum. Frelburg-BaselWien 1982 .

Petuchowski, Jacob J., Aus der Geschichte erwacheen: die jtraleche Plîrität heute. Vortrag Aachen, 18 juni 1983.

Peursen, C.A. van, strategie van de cultuur. Een beeld van de veranderingen in de hedendaage denk- en leefwerela. Amsterdam-Brumsel 1972 .

philipsen, H., Omvang van de gezondheidszorg onder invloed van maatschappelijke ontwikkelingen. In: Tijaschrift voor sociale Geneeskunde 54,1976,198-207.

De plaats van de medicus in het eerste echelon. Diskusienota Comulssie Eerate Echelon KNMG. In: Medisch Contact 31,1976,14,139165 .

Poorthuis, M. Het comcept van genezing in de foodse traditie. In: J.H. Hagen (red.), Geloven in gezondheidszorg. Lochem-Poperinge 1982 .

Praag, H. van, Hermeneutiek. In: Intermediair $7,1971,39,17-21$. Prager, Jos.. Begegnungen auf dem Wege. In: Bertha Badt-Strauss u.a. Franz Rosenzweing Ein Buch des Gedenkens. Berlin 1930,39-43. Preuss. Julius, Biblisch-talmudiache Medizin. Beltrăge zur Geschichte der Heilkunde und der Kultur therhaupt. Beridn 1911. Westmead 1969, New York 1971.

Prywes, Moshe, Merging medical education and medical care. In: The hospital medical staff, Vol.2, August 1973.

Prywes, Moshe, The Beersheva experiment. Paper colloquilum "Future of basic training of the family physician". Brussels, 20-24 November 1978 .

Querjdo, A., Inleiding tot een Integrale geneedkunde. Lochem 1955. $1973^{2}$.

Rashie's Pentateuch-comentaar. Zie onderwijzer.

Fiphagen, F. E., Zeven vette Jaren. Fen beschrijuende analyo van multidisciplinaire samenwerking in Rotterdam-ommoord (diss..).

Roterdam 1980 .

Rodrigues. Pereira, H.M.M. Poppers, R.C. Musaph-Andriesse, $w$. Whitlau, J. Kruis, P.W. Van Boxel, J.S. Vos, Vreugde om de Tora. Kampen 1984.

Root, J.M.H. op ' $t$, Gezondheldscentrum Rotterdam-Omoord. In: H.J. Dokter, Tom van den Grinten en Gaspard A.de Jong (red.). Gezondheid en gezondheldacentra. Ervaringen met samenwerkingswerbanden in de eerstelijnsgezondheidszorg. Amsterdam 1974.

Root, J.M.H. op ' $t$, De huigartsopleiding an de Rijksuntuer itelt Limburg. Uitgangspunten, opzet, ervaringen. In: Huibart en Wetenschap $22,1979,7,278-282$.

Root, J.M.H. op "t, David Hartman over het scheppen van ruinte voor de integriteit van de ander. Enkele antekeningen. In: Ter Herkenning $10,1982,2,59-62$.

Root, J. op 't. Franz Rosenzweig en het Vrije Joodse leerhuis. In: I.B.H. Abram, C.P. Rosenzwelg, J. op "t Root, M.Th. Wolff-kunite- 
nat, P.J. Tomol, S. Schoor, H.J. Buyer, Beth ha-Midrasj-1eerHulE. Exwringen van joden en chritenen. Kampen 1983.

Rosenetok-Huessy, Eugen, Argewandte seejenkunde. Ir: id. Die Spache des Menschergechlechto. Eroter Band. wweiter Teil. Heidelberg 1963 .

Rosengtock-muesgy, Fugen, De anbetadibare meris Rotteram 1966.

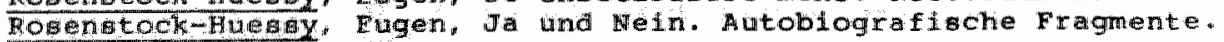
He 1 iberg 1968 .

Rogengtock-Huebsy. Eugen (ed.), Judalem degpite christianity. The "Letex on chxistanity and Judalsm" between Eugen Rosenstock-

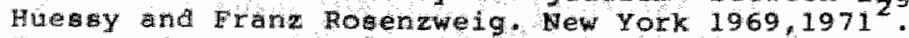

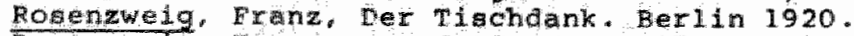

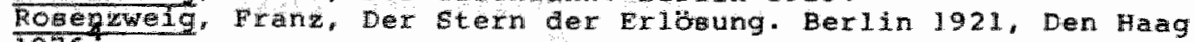
1976

Rogenzwelg, Franz, Jehuda Helevi. Sechzig Hymnen und Gedichte. Konstanz 1924

Fosenzweig, Funz, Jehuad Halevi. Zwelunoneunzig Hymnen und Geajite. Deutsch mit elnem wachwort und in Ammerkungen. Zweite Augare Berin 1927 .

Rovenzweig, Frand, Briefe. Berlin 1935.

Roserzwelg, Franz, Kleinexe Schriften. Berlin 1937.

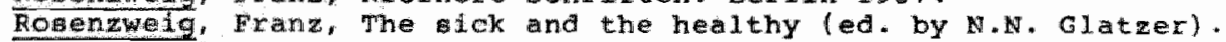
Wew YOR 1953

Rosenzwelg. Franz, on Jewish leaxning (ed. by N.N. Glatzer): New York 1955

Rosenwwig, Fanz, Da Buchlein vom gesunden ura kranken Menschenveratand. Dusseldorf 1964 .

Rosenzwe1g, Fanz, Briefe und Trgebucher. Bd.1-2. Hag 1979.

Rosenzweig, Fxanz, Jehuda Hallevi. Finfundneunzig Hymen und Grealchte. Deutsch und Febrebsch mit elnem Vorwort und Anmerkungen. Ditute Ausabe. The Hague-Boston-Lancaster 1983.

Rosenzweig, Rachel, Die solidaritat mit den Leidenden im Judentum. Eer1in 1978 .

Forner Fred and Moses D. Tendler, eractical Medical Halacha. Terusalem-New York 1980 .

kosner. Fred, The traditionalist Jewish physioian and modern blomedical ethical problemg. In: The Journal of Medicine and phillopol, Vol.8, no.3, A ugust $1983,225-241$.

Roth. Cecil (ed.). Encyclopaedia Judaicai zie aldaar.

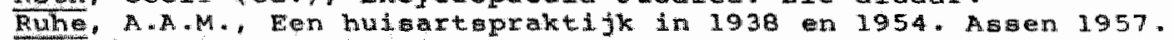

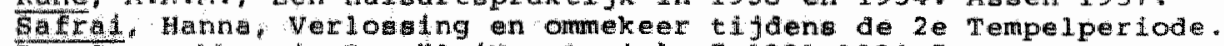
in: Gespreken Ln I räl (Mes Ammin), 7, 1981-1982.5.

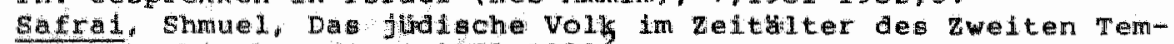

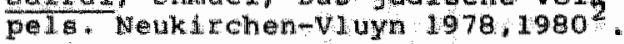

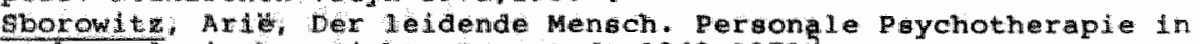
shetropologidoher soht. Darmetadt 1969, 1979 "

sonaeder, Grete, Martu Buber, Hebralscher Humanimus. Gottingen 1966 .

Schaefter, Richard, Dermhard Kasper, Shemaryahu Talmon, yehosha

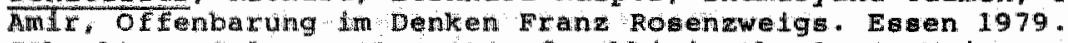
shechter, solomon, Apets of rabbinic theology. Major concept of the Thind New York 1909. New edition, New Xork 1961.1975". Sehepptra, S.E. Het Lermula. Aspekten van het onderwis in het

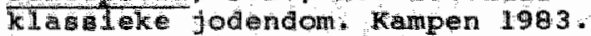

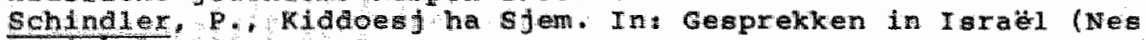
Aminin) B, $1982-1983,2$.

Schinale ruben, Confromting terminal illness and death in

relJiour jewsh society intsIDIC-Service international de document tion judeomehreienne, Vol.XVI, no.3,1983,12-17.

scholem Gershon, veben elinge crunabegriffe des Judentums. FrenkFurt ${ }^{2}$ in $1970,1976^{2}$. 
Schouten, I.A.M., Anamnese en advies. Nieuwe richtiljnen woor de Informatieuitwisseling tussen arts en patient. Alphen aran de RijnBrusisel 1982 .

Schrey, Heinz-Horst, Dialogisches Denken. Darmstadt 1970 .

Die Schrift. Verdeutscht won Martin Buber gemeinsm mit Fran Rosenzweig. T1.1.Die funf Bucher der Weisung. T1.2.Bticher der Geschichte. T1.3.Bucher der Kindung. T1.4.Die Schriftwerke. Heidelberg 1976.

Segal1. Ascher, Moshe Prywes, Dan E.Benor, Oded susskind, University centre for health sciences. Ben Gurion University of the Negev, Beer sheva, Israel: An interim perspective. Geneva, 1976, 11. $2-132$.

Seltzer. Robert M., Jewish people, Jewish thought. The Jewisch experience fin history". New York-London 1980 .

Simon. Ernst, Versuch ther Franz Rosenzweig. In: Bertha BadtStrauss u.a., Franz Rosenzweig. Ein Buch des Gedenkens. Beriin $1930,31-38$.

Singer, 5 . (ed.), The authorised dally prayer book. London $1962^{2}$. Sirach. Jesus (Jesus ben-Sira), Boek van de wjjsheid. In: R.K. uitgave van de Heilige Schrift. Utrecht-Antwerpen 1962, 765-820. Sluis, D.J. van der, P.J. Tomson, D.J. van uden en W.A.C. Whitlau, Elke Morgen vieuw. zie aldaar.

Smelik, K.A.D. (samenst.). Jodendom. Btbliografle over het

jodendom en Israêl voor het Nederlands taalgebied. "s-Gravenhage 1983.

Soetendorp, J.. Ontmoetingen in ballingschap I. Zeist-Arnhem-

Antwerpen 1964 .

Soetendorp. J.; De wereld van het optimlame. Het jodendom in wezen en verschijning. Bussum 1970 .

Sperna Weifand, $\mathrm{J}$." Oriëntatie. Nieuwe wegen in de theologie.

Sperna Weiland, J." Voortgezette oriëntatie. Nieuwe wegen in de theologie. Barn 1971,1972.

Sperna Weiland, J.. Jehuda Aschkenasy, M.A. Beek en D. Tiemerma, Martin Buber. Baarn 1978.

Spicehandler, Ezra, De joodse literatuur. Het Hebreeuws verhalend proza. In: Elie Kedourie, De joodse wereld, Geschiedenit en cultuur van het joodse volk. Antwerpen 1980,253-258.

sporken. Paul, Ethiek en gezonaheidszorg. Baarn 1977.

spreelwenberg. C.. Wat betekent voor de hulsart integrale zorg?/1 Fen beschouwing over de term "integrale zorg". In: Huidart en Wetenschap $25,1982,88-92$.

Stemberger, Günter, Der Talmud. Einfthrung, Texte, Erlauterungen. Minchen 1982 .

Stórig. Hans Joachim, Geachjgaenis van de filonofle 1 en 2. Utrecht-Artwerpen 1959.1974 .

Stragk, Hermann L.. Finleitung in Talmua una Midrasch. Munchen $1976^{\circ}$

Strasser; 5 ., Fenomenologie en empiribche menskunde. Deventer 1962.1973.

Strasser, Stephan, Jenseits von sein und zeit. Eine Einflinung in Emmanuel Levinas' Philosophie. Den Haag 1978.

Strasser. Stephan, De burger voorbij. Ethisch-politieke overwegingen. Baarn 1.981 .

De taken yan de huisarts. Rapport van de commilalie Takenpakket der LHV. In: Medisch Contact 32,1977, 763-789.

Talmon, Shemaryahu, Kritische Anfrage der jisische Theologie an das europäische Christentum". In: Werner Lichartz und Martin stonr (Hrsg.). Einladung Ins Lehrhaus. Beitrage zum judischen selbstyerständnis. Frankfurt am Main 1981 .

Terracina, Fernando, Jews and non-jews: what are the differences? 
A research wentil for mutual wharetanding. In StDic-service internetomal de documentation Judeo-chretienne (engligh edition) Vol.XVII, No. $1,1984,21-24$.

Tewer. Joreph, Zum Existenzbegriff Franz Rosenzweigs. Meisenheim an GI 1970 .

Theuntser. Miehat, Der Andere. Stugien zur Sozilontologie aer Gegerwart. Eer11n-Wew Tork $1976,1977^{2}$.

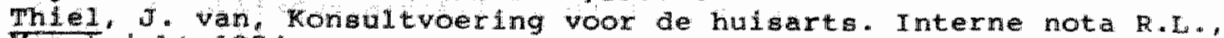
Tavericht 1984

Tombon. $0 . z e$ dagen zul je werken - en de zevende dag staken.

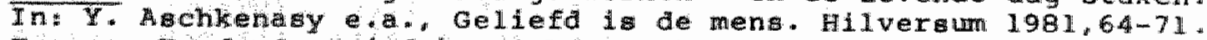
Travere Hextom, R. (ed.), pirke Aboth. The ethics of the Talma: sayings of the Fathers. New York 1945.1978

Trumbe, Keef, Psychosociale klachten in de eerstelijna gezonaheidszorg. In: H.J. Dokter, Tom van der Grinten en Gaspra A. de Jong (red.). Gezondheid en gezondheldacentra . Ervaringen met samenwerkingswerbanden in de eersteljus gerondheidszorg. Ansterdam 1974.

Trimbos, Kee Integrale geneekunde (na 20 farr). In: Maandblad voor Geetelljke volkegezondheld, 31, 1976, 64-72.

Trlbb, Nan*, Heilung aus der Begegnung. Eine Auseinandersetzung mit der prychologi C. J Jungs. Mit elnem Gletwart von Martin Buber. stuttgate $1951,1971^{3}$

Tweraky, I adore, Matmonides. In: Jacob Meusner (ed.), UnderstanIIng rabbinic Judalsm. From tamudic to modern times . New York $1974,187-214$

Twersky Isadore, The Shulkan Aruk: snduring code of Jew lsh law. In: Juabih Goldin (ed.). The Jewish expression. New Haven-Loncon $1976,322-343$

Uaer, D.J. wan, Gezegend Gij Heer "over bidaen en gebed in de Joodse traditie. Kampen 1978 .

vaen, D.J. van. "Als je leven zoekt'. De interpretatie van het woord 'leven' in PB.16,11 in de rabbifnse 1iteraturi. In: Y.Aschkenasy e.a. Geliefa is de mens. Hiversum 1981,40-56.

Uden, D.J. van, chesed. over de relatie hulpverlener-cijent vanult bijbels gezichtspunt. In: $Y$. Aschkenasy e a. Geliefd is de mens. Hil versum $1981,104-115$.

Urbach, Ephraim, E. Thg sageg. Their concepts and bellets. Vol.III. Jeruga 1em $1975,1979^{2}$.

Veit, Reinhard, Der didaktiohe Ansatz von Franz Rosenzweig

(als.). Dortmund 1973 .

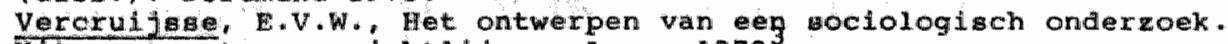
Ultgangepunten en richtijinen. Asten $1970^{3}$.

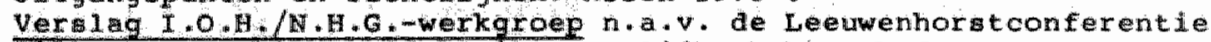
T991 over problemueld II Persoonlj jke bekwamheden en persoon1.jhe torueting van de huigarts". Wiet gepubliceerd verslag. Utrect 1982 .

Vries, E. de, Gezin en hulpverlentng in Dorp bif stad (dise.). Nimegen 1973 .

Vries, J. de Etrmologieh woordenbogk. War komern de woorden vandate Utrecht-Antwerpen 195.1979 .

Vxieg. Mrg." S.Ph. de. Joodae riten en symbolen. Amsterdam 1927$1932,1978^{4}$

Waljman. Kees, De myotiek van ik en jij. Fen nieuwe vertaling van

'Ich und Du' van Mrrtin Buber met inielding en uitieg en en doordenking van het systeem dat exaan ten grondslag ligt (disa.). Utecthe 1976 :

Warjuan, Kees, palmen bij ziekte en genering verkining van een bljbalgederelte. Kampen 1981 .

Wamenhoven o. Canonische variaties op en onvermijdelijk thema. 
In: Tijdschrift voor Agologie, $1972,5,252-267$.

Warmenhoven, Okko, Prolegogena tot de androgologische propaedeuse (diss.). Utrecht $1973,1983^{2}$.

Wehr. Gerhard, Martin Buber. Baarn 1971

Weingr, Herbert, 9t Mystics. The Kabbala today. New York 1969, $1979^{\circ}$.

Weizbäcker, C.F. von, De draagwijdte van de wetenschap. Amsterdam 1966 .

Weizal̈cker, Viktor von, Arzt und Kranker I. Stuttgart 1949 .

Weizä̈cker, viktor von, Begegnungen und Entscheidungen. Stuttgart $1949.1951^{2}$.

Wesiack. Wolfgang, Psychosomatische ziekten. Baarn-Antwerpen 1976 . Weljel, J.A.. De mensen hebben geen leven. Een psychosociale studie. Haarlem 1970 .

Whitlau, W.A.C., Torah van Sina I (Intern overzicht Folkertsma

Stichting voor Talmudica). Hilversum z.j.

Whitrow, G.J." Wat is tija? Utrecht-Antwerpen 1974 .

Wigoder, Geoffrey (ed.), Jewish Values. Jerusalem 1974.

Wisser, Richard, verantwortung im wandel der zeit. Einthung in gelistges HandeIn: Jaspers, Buber, C.F. von welzskcker, Guardini, Heidegger. Mainz 1967 .

Wolff, Hags Walter, Antropologie des Alten Testaments. Mtinchen $1973,1984^{4}$.

Wolff, H., Mose ben Maimún's (Maimonides) Acht Capitel. Leipzig 1863 .

Wolff, Marion, Gedachten over het leerhuis. In: wending 34,1979, $6.362-368$.

Woudschotenrapport. Rapport over de taak van de hulsarts. De zogenaamde Woudschotenmaterie. Commissie Wetenschappelijk onderzoek van het Nederlands Huisartsen Genootschap. z.p.,z.j.

zobel, Moritz, Der Sabbat. Sein Abbild im flidischen Schrifttum, seine Geschichte und seine heutige Gestalt. Berlin 1935 .

zuidema, Yillem, Gods Partner. Ontmoeting met het jodendom. Baarn $1977,1982$.

zuidema, willem, e.a.. I aak wordt weer geofferd. De verwerking van de holocaust door jodendom en christendom. Baarn 1980. zuidema. Willem, e.a." Betekenis en verwerking. Het offer van Isaak en de holocaust. Baarn 1982.

zuidema, Willem. Het joodse rouwproces: de zin van het ritueel. In: Tex herkenning $11,1983,4,73-81$.

Zwi Marx, Claude, Bali ingechap en verloseing. Int Gesprekken in I araél (Ne Armim). 8, 1982-1983,7..

Zwi. Werblowaki, R.J." De joodse myatiek. In: Elie Kedourle, De Joodse wereld. Openbaring, profetisme en geschiedenis. Antwerpen 1980 . 
, 
De schrijver van dit proefschrift werd op 9 augustus 1940 geboren te Nederweert.

$\mathrm{Na}$ de middelbare school en de vervulling van zijn militaire dienstplicht studeerde hij aan de Sociale Akademie te Eindhoven. In 1967 behaalde hij aldaar het diploma voor matschappelijk werker. Hierna kreeg hij een funktie als algemeen maatschappelijk werker in Rotterdam. Vanaf eind 1968 tot januari 1973 maakte hij als zodanig deel uit van het kernteam van het Gezondheidscentrum "Ommoord' in Rotterdam. Intussen volgde hij parttime een voortgezette opleiding aan de Sociale Akademie in Rotterdam en in 1970 behaalde hij het diploma voor opbouwkonsulent. In dat jaar ook begon de schrijver met de studie in de andragogische wetenschappen an de Rijksuniversiteit te utrecht. In augustus 1974 behalde hij cum laude het doctoraalexamen.

Sinds september 1974 is hij aan de Rijksuniversiteit Limburg werkzaam bij de kapaciteitsgroep Huisartsgeneeskunde.

Daarnaast was hij van 1978 tot medio 1984 voorzitter en sindsdien is hij bestuurslid van het Leerhuis Limburg in Maastricht. 